九州大学学術情報リポジトリ

Kyushu University Institutional Repository

Fusuline Fossils from Thailand, Part IX Permian Fusulines from the Rat Buri Limestone in the Khao Phlong Phrab Area, Sara Buri, Central Thailand : Contribution to the Geology and Palaeontology of Southeast Asia, CLXX

Tor iyama, Ryuzo

Geological Laboratory, Faculty of Science, Fukuoka University | Formerly Department of Geology, Faculty of Science, Kyushu University

https://doi.org/10.5109/1544172

出版情報：九州大學理學部紀要：Series D, Geology. 23 (1)，pp.1-116，1975-03-10. Faculty of Science, Kyushu University バージョン:

権利関係 : 
Mem. Fac. Sci., Kyushu Univ., Ser. D, Geology, Vol. XXIII, No. 1, pp. 1-116, text-fig. 1, tables 1-40, pls. 1-21, March 10, 1975

\title{
Fusuline Fossils from Thailand, Part IX Permian Fusulines from the Rat Buri Limestone in the Khao Phlong Phrab Area, Sara Buri, Central Thailand
}

\author{
Contribution to the Geology and Palaeontology \\ of Southeast Asia, CLXX
}

Ryuzo TORIYAMA*

\begin{abstract}
The present paper deals only with the systematic paleontology of the rich faunas collected from the B Formation of the Khao Phlong Phrab section, Amphoe Phra Butthabat, Changwat Sara Buri in Central Thailand. The fusuline fauna contains 91 species of 26 genera comprising Ozawainella, Toriyamaia, Neofusulinella, Yangchienia, Schwagerina, Pseudofusulina, Parafusulina, Monodiexodina, Chusenella, Misellina, Brevaxina, Verbeekina (Armenia), Verbeekina (Verbeekina), Verbeekina (Paraverbeekina), Pseudodoliolina, Metadoliolina, Cancellina, Presumatrina, Maklaya, Neoschwagerina, Colania, Nankinella, Sphaerulina, Eoverbeekina, Thailandina, and Neothailandina. The present paper describes 66 species including 9 new species and subspecies of the above-mentioned genera except for the species of Neofusulinella, Maklaya, Thailandina, and Neothailandina which were already described.

The Khao Phlong Phrab fusuline fauna bears, as a whole, typical Tethyan aspects and furnishes a good key to a consideration of the phylogenetical development of fusulines, especially that of verbeekinids, neoschwagerinids and thailandinids in the late Early to the middle Middle Permian times.
\end{abstract}

\section{Contents}

Introduction and Acknowledgements $\ldots \ldots \ldots \ldots \ldots \ldots \ldots \ldots \ldots \ldots \ldots \ldots, \ldots \ldots \ldots$ Page Plate Systematic Paleontology

Family Ozawainellidae

Ozawainella akiyoshiensis ToRIYAMA.................... 5 1

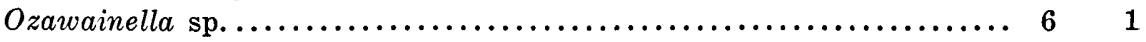

Toriyamaia sp. ...................................... 6 1

Family Schubertellidae

Neofusulinella saraburiensis TORIYAMA, KANMERA and INGAVAT......... 1

Neofusulinella praecursor DEPRAT $\ldots \ldots \ldots \ldots \ldots \ldots \ldots \ldots \ldots \ldots \ldots \ldots \ldots \ldots 1$

Neofusulinella lantenoisi DEPRAT........................... 1

Yangchienia cfr. compressa (OzAWA)..................... 7 . 1

Manuscript received December 15, 1974.

* Geological Laboratory, Faculty of Science, Fukuoka University. Formerly Department of Geology, Faculty of Science, Kyushu University. 
Yangchienia haydeni Thompson ......................... Page Plate

Yangchienia tobleri THOMPSON ........................... 9

Yangchienia thompsoni SkINNER and WILDE................. 11

Family Schwagerinidae

Subfamily Schwagerininae

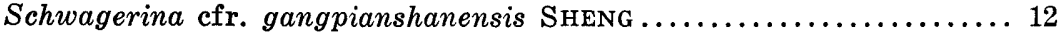

Pseudofusulina kueichowensis obesa SHENG.................. 14

Pseudofusulina regularis (SchellwiEN).................... 15

Pseudofusulina cfr. uenoensis KoвaYAsHr................... 16

Parafusulina cfr. elliptica SHENG ........................ 18

Parafusulina gruperaensis gruperaensis THOMPSON and MILLER ..... 20

Parafusulina gruperaensis brevica SHENG ................... 22

Parafusulina quasigruperaensis SHENG ....................... 23

Parafusulina yabei HANZAWA............................ 23

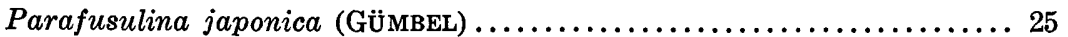

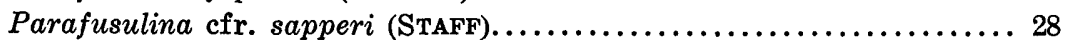

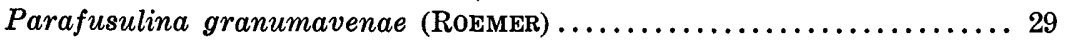

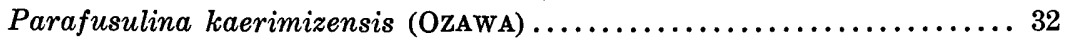

Parafusulina nosonensis THOMPSON and WHEELER .............. 34

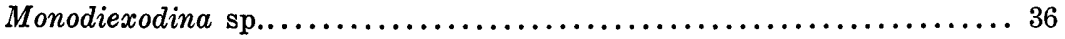

Subfamily Chusenellinae

Chusenella cheni SkINNER and WILDE ..................... 37

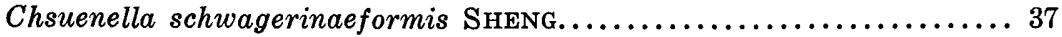

Chusenella cfr. alpina (KochANSKY-DEvidé) $\ldots \ldots \ldots \ldots \ldots \ldots \ldots \ldots \ldots 40$

Chusenella? chihsiaensis (LEE) ........................... 41

Chusenella tenuis TORIYAMA and KANMERA, n. sp.............. 43

Chusenella sp. A................................... 45

Chusenella? sp. B................................... 46

Family Verbeekinidae

Subfamily Misellininae

Misellina (Misellina) otai SAKAgUchi and Sugano................ 48

Misellina (Misellina) cfr. termieri (DEPRAT) ..................... 49

Misellina (Misellina) subelliptica (DEPRAT) ................... 51

Misellina (Misellina) confragaspira LEVEN .................. 53

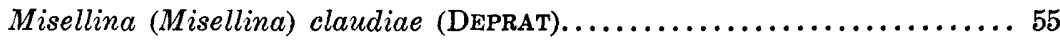

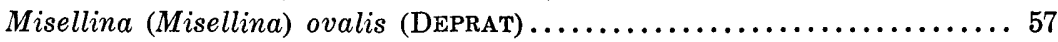

Misellina (Brevaxina) compressa (DEPRAT) .................... 58

Subfamily Verveekininae

Verbeekina (Armenia) saraburiensis TORIYAMA and KANMERA, n. sp... 59

Verbeekina (Armenia) karinae MikLUKHo-MaKLAY .............. 61

Verbeekina (Armenia) prisca TORIYAMA and KANMERA, n. sp........ 62

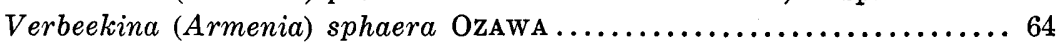

Verbeekina (Verbeekina) verbeeki (GEINITZ)................... 66

Verbeekina (Paraverbeekina) pontica MikLUKHo-MaKLAY...........6 68

Subfamily Pseudodoliolininae

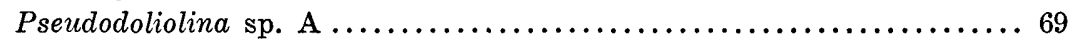

Pseudodoliolina saraburiensis TORIYAMA and KANMERA, n. sp.......71

Pseudodoliolina primigena TORIYAMA and Kanmera, n. sp. ........ 73

Pseudodoliolina gracilis TORIYAMa and KanMERA, n. sp.......... 75

Pseudodoliolina ozawai minima MiklukHo-MakLAY .............. 77

Pseudodoliolina ozawai ozawai YABA and HANZAWA ............. 77

Metadoliolina pinguis TORIYAMA and KanMERA, n. sp........... 81 
Family Neoschwagerinidae

Subfamily Sumatrininae

Cancellina phlongphrabensis TORIYAMA and KANMERA. n. sp....... 8316

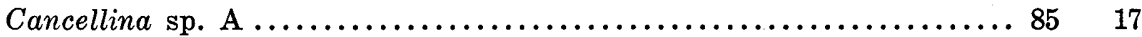

Cancellina tenuitesta KANMERA........................ $88 \quad 17$

Cancellina neoschwagerinoides (DEPRAT) ................... $88 \quad 17$

Presumatrina schellwieni (DEPRAT)....................... $90 \quad 17,18$

Presumatrina cfr. grandis LEven ........................ $93 \quad 18$

Subfamily Neoschwagerininae

Maklaya saraburiensis KANMERA and TORIYAMA.................. 18

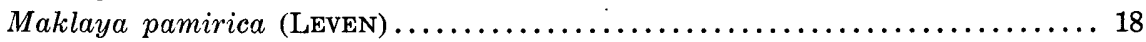

Maklaya sethaputi KANMERA and TORIYAMA.................. 18

Neoschwagerina schuberti KochansKY-DEvidÉ................ $95 \quad 19$

Neoschwagerina simplex tenuis TORIYAMA and KANMERA, n. subsp.... $97 \quad 19$

Neoschwagerina simplex simplex OzawA .................... $99 \quad 19,20$

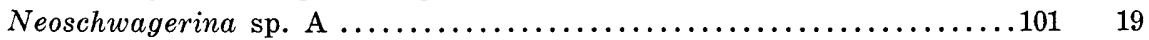

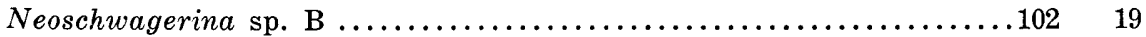

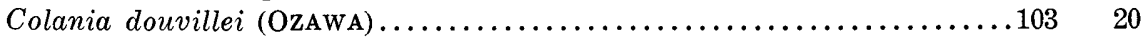

Family Staffellidae

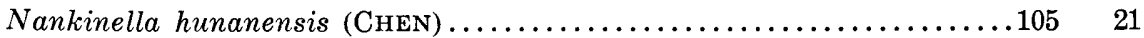

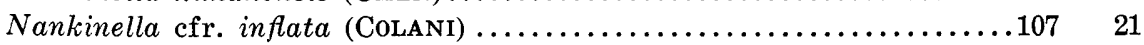

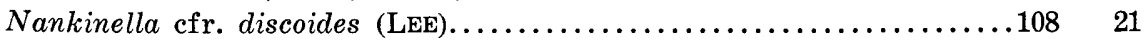

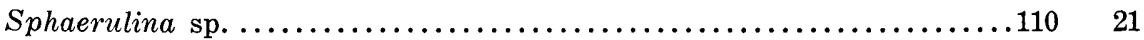

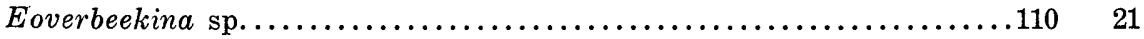

Family Thailandinidae

Thailandina buravasi TORIYAMA and KANMERA................... 21

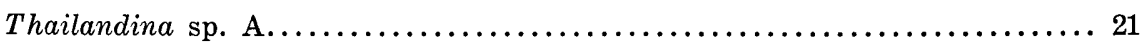

Thailandina hongnusonthiae TORIYAMA and KANMERA............... 21

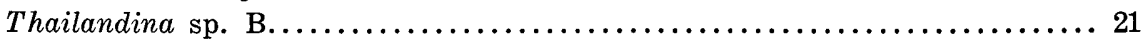

Neothailandina pitakpaivani TorIYAMA and KANMERA.............. 21

Neothailandina komalarjuni TORIYAMA and KANMERA............... 21

References..........................................

\section{Introduction and Acknowledgements}

The Rat Buri Limestone, the calcareous facies of the Carboniferous-Permian Rat Buri Group, is widely distributed in Thailand and often prolific in fusulines, brachiopods, bryozoans, corals, calcareous algae, and conodonts, but very rare in ammonites. Since the fusulines are of prime value for age-determination and establishing fine biostratigraphic zone in calcareous rocks, many of earlier paleontological works have been focused to describe fusuline faunas found from many localities.

Since the pioneer reports on the occurrence of this group of fossils from the Pawa Limestone (DUNBar, in HeIM and HIRSCH, 1934), ToRIYAMA (1944), KoNISHI (1953), ToriYama and Sugi (1959), PitakPaivan (1965), Toriyama and Kanmera (1968), SaKagami 1968, 1969), Kanmera and ToRiyama (1969), Toriyama, KaNmera and IngaVat (1969), OzaWa (1970), Igo (1972), ToriYama and PitakPaivan (1973), and SAKAGAMI and IWAI (1974) described many fusuline species from various localities. All the species described in these reports have been referred to the Permian in age, except for those described by Igo from northern Thailand which are of Middle and Upper Carboniferous age.

The present paper deals only with the Systematic Paleontology of the Permian fusulines collected from the Khao Phlong Phrab hills, located about 3 to 4 kilometers 
south-southeast of the Phra Butthabat junction, Amphoe Phra Butthabat, Changwat Sara Buri, Central Thailand. The limestones are quarried along the northern slope of the Khao Phlong Phrab hills, along which detailed stratigraphic section was measured meter by meter.

The biostratigraphic zonation established at Khao Phlong Phrab (Table 1) is the best reference section for the upper Lower to middle Middle Permian formations not only in Thailand but also in its adjacent areas in Cambodia, Malaya and probably in Burma. As for the exact location of Khao Phlong Phrab, the sampling locations of the fusuline limestones in the Khao Phlong Phrab section, the definition, lithofacies, and faunal characteristics and assemblage in each zone in the Khao Phlong Phrab section with its correlation with related areas, the readers are requested to refer a paper titled "Biostratigraphic zonation of the Rat Buri Limestone in the Khao Phlong Phrab area, Sara Buri, Central Thailand" presented by R. Toriyama, K. Kanmera, S. Kaewbaidhoon, and A. Hongnusonthi. (Geology and Palaeontology of Southeast Asia, Volume 14, pages 25-48, 1974).

Table 1. Fusuline zonation of the Rat Buri Limestone in the Khao Phlong Phrab Section, Sara Buri, Central Thailand (After R. ToriYama, K. Kanmera, S. KAEWBAIDHOON, and A. HoNGNuSONTHI, 1974)

Upper C Formation: Limestone conglomerate



$\mathrm{B}_{7}$ Presumatrina schellwieni zone
$\mathrm{B}_{5}$ Maklaya sethaputi zone
Middle B Formation
$\mathrm{B}_{4}$ Maklaya pamirica zone
$\mathrm{B}_{3}$ Maklaya saraburiensis zone
$\mathrm{B}_{2}$ Misellina confragaspira zone
$\mathrm{B}_{1}$ Misellina otai-Misellina cfr. termieri zone
fault (?)
Lower A Formation: Mostly crystalline limestone

From the paleontological viewpoints, the Khao Phlong Phrab fusuline faunas have an important significance in the consideration of evolutionary development in several bioseries in the verbeekinoids. Especially, they furnish a good key to the consideration for the earliest developmental stage of the bioseries of MisellinaMaklaya-Neoschwagerina, Misellina-Cancellina-Presumatrina, Misellina-Pseudodoliolina-Metadoliolina, and Misellina-Verbeekina (Armenia)-Verbeekina (Verveekina). Consideration and discussion on these problems will be given by TORIYAMA and KANMERA in another paper in future.

The limestone materials used in this study were collected by R. TORIYAMA and K. KaNMERA in cooperation with Sangob KaEwbaIdHoAM and A-ngoon HoNGNUSONTHI of the Department of Mineral Resources of Thailand during the paleontological and geological reconnaissance surveys held in the winter seasons of 19621963 and 1964-1965. A larger part of thin section was made by KANMERA and also about a half of microphotographs were taken by him.

Repository;-The type specimens and about a half of the limestone materials are kept in the Department of Geology, Faculty of Science, Kyushu University, with the designation of GK.D for the registered number of the specimens. Another half of the materials is kept in the Museum of the Department of Mineral Resources, Thailand at Bangkok. 
Acknowledgements:-The writer is much indebted to Dr. Kametoshi Kanmera of Kyushu University for his warm cooperation in sectioning limestone materials, taking microphotographs, and rousing helpful discussion concerning the phylogeny of verbeekinoids. Without his cooperation the present study could not be done. The writer is also much indebted Mr. Sa-ngob KaEWBAIDHOoN and Miss A-ngoon HoNGNUSONTHI of the Department of Mineral Resources who collaborated with him in measuring the sections and sampling fossils in the field.

The writer expresses his sincere thanks to Mr. Saman Buravas, Director General, Mr. Vija SeThaPUT, former Director General, Mr. Kaset PitaKPaIVAN, Director of the Geological Survey Division, the late Mr. Pumwarn KomalarJun, Mr. Din BunNaG, and other staffs of the Department of Mineral Resources, Thailand for their hearty cooperation in carrying out the paleontological and stratigraphical surveys.

The writer gratefully acknowledges Professor Emeritus Teiichi KoBaYAsHI of the University of Tokyo who undertook the leadership for paleontological reconnaissances in 1962-63 and 1963-64 in Thailand. The writer's cordial thanks are due to Professor Tatsuro Matsumoto, Professor Tsugio Shuto, Dr. Juichi YanaGIDA, Dr. Takeshi Ishibashi and Dr. Tomowo OzaWA of Kyushu University for their continuous encouragement, and also to Miss Seiko HAYAKaWA who helped the writer in the preparation of typescript, microphotographs and figures.

Financial support for the present study was provided by The Asia Foundation, Japan Chapter in Tokyo, the Overseas Technical Cooperation Agency, Ministry of Foreign Affairs, the Overseas Research funds and Scientific Research funds, Ministry of Education, Japanese Government, and many other private companies.

\section{Systematic Paleontology}

Order Fusulinida FurSEnKo, 1958

Family Ozawainellidae Thompson and Foster, 1937

Genus Ozawainella Thompson, 1935

Ozawainella akiyoshiensis TORIYAMA

Pl. 1, Figs. 1-3

1958. Ozawainella akiyoshiensis TorIYAMA. Mem. Fac. Sci. Kyushu Univ. Ser. D, Geol., vol. 7, p. 64-65, pl. 1, figs. 1-4.

Material:-Axial sections, GK.D 13128c from Kpp-39, GK.D 13375 from Kpp-53; tangential section, GK.D 13367 from Kpp-53.

Description:-Shell is small and considerably thickly lenticular in shape, with acutely angular periphery, almost straight to slightly convex lateral slopes and obtuse polar regions. Apical angle is $64^{\circ}-72^{\circ}$. Mature shell of 6 volutions is $0.62-$ $0.69 \mathrm{~mm}$ in length and $1.26-1.28 \mathrm{~mm}$ in diameter, with a form ratio of 0.54 Inner three volutions take less angular periphery, and outer three to four volutions are almost the same in axial profile.

Exact dimension of proloculus is not known, because the illustrated sections are not cut just through the center, but seems to be spherical with an approximate outside diameter of 50 microns. Shell coils tightly in the first two volutions, and from the third volution it expands rapidly and uniformly. Radius vectors of the 
first to sixth volutions are $63,128,200,320,465$, and 655 (?) microns, respectively in one of axial sections (GK.D $13128 \mathrm{c}$ ). Those of another axial section (GK.D $13375) 70,140,210,310,440$, and 660 microns, respectively.

Spirotheca is thin. Its minute structure is not detected because of poor state of preservation, but it seems to have four-layered type of spirotheca at least in the fourth and fifth volutions. Thickness of spirotheca is $11,14,14$, and 19 microns, respectively in the second, fourth, fifth and sixth volution.

Septal arrangement and their structure are not known, since no sagittal section is available. Tunnel is also obscure.

Remarks:-Although only two axial and one tangential sections have been available in the present collection, all the important characters observed in the present specimens are well agreed with those of the Akiyoshi specimens.

Among three unnamed new species of Ozawainella described by PITAKPaIVAN (1695) from Chondhurian, near Takli, Central Thailand, $O$. sp. A closely resembles the present species in the shape, dimension and important characters, and both may be conspecific with each other.

Occurrence:-Rare at Kpp-39 and -53. The $\mathrm{B}_{5}$ and the lower part of the $\mathrm{B}_{6}$ zone.

Ozawainella sp.

Pl. 1, Fig. 4

Material:-Axial section, GK.D 13043 from Kpp-29; tangential section, GK.D 13676 from Kpp-51.

Description:-Shell is relatively large for the genus. It assumes a thick lenticular form with nearly straight to slightly convex lateral slopes, angular peripheries and obtuse poles. Only available axial section is $0.84 \mathrm{~mm}$ in length and $1.84 \mathrm{~mm}$ in width, with a form ratio of 0.46 . Apical angle measures $45^{\circ}$.

Proloculus seems to be spherical, with an outside diameter of about 70 microns. Shell expands nearly uniformly. Half lengths of the third to seventh volutions are $150,190,270,350$, and 450 microns, respectively. Radius vectors of the second to seventh volutions are $220,320,420,610,790$, and 1020 microns, respectively. Ratios of half length to radius vector are $0.47,0.45,0.44,0.44$, and 0.44 , respectively in the third to seventh volutions.

Spirothecal structure is not known exactly due to unfavourable state of preservation. Spirotheca is thin, with a thickness of 13,17 and 16 microns in the fifth, sixth and seventh volutions, respectively.

Remarks:-Ozawainella sp. is considerably large for the genus. It somewhat resembles Orobias kueichihensis described by CHEN (1934) from the uppermost bed of the Chihsia Limestone, Litzekèng, Kueichih, Anhui, South China. It differs from the latter in having somewhat larger size of shell and thinner spirotheca. The present species is most closely allied to $O$. sp. B described by PITAKPaIvaN (1965) from the Chondhurian, near Takli, Central Thailand. Only difference is in smaller apical angle in the present specimen, and both are assumed to be conspecific with each other.

Occurrence:-Rare at Kpp-29 and -51 . The $\mathrm{B}_{4}$ and $\mathrm{B}_{5}$ zones.

Genus Toriyamaia KANMERA, 1956

Toriyamaia sp.

P1. 1, Fig. 5 
Material:-Oblique section, GK.D 13464

Description:-The specimen at our disposal is represented by only a single oblique section which is $1.10 \mathrm{~mm}$ in length and $0.55 \mathrm{~mm}$ in width. It seems that inner volutions coil askew to the axis of outer volutions.

Spirotheca is thin, being 17 and 18 microns in outer two volutions. Spirotheca consists of very thin tectum and a structureless lower layer at least in a part of shell, but it is apparently composed of a single structureless layer in most part of shell, probably because of unfavourable state of preservation. Septa almost plane.

Remarks:-The genus Toriyamaia is monotypic at present represented by the type species, $T$. laxiseptata KANMERA, originally reported from the conglomerate bed of the Kozaki Formation in South Kyushu, Japan. Although it was found in a pebble of conglomerate, it is associated with Misellina aff. clauliae (DEPRAT), Pseudofusulina parumvoluta (DEPRAT), P. vulgaris (SCHELlWIEN), Nagatoella aff. kobayashii Tномpson, Nankinella sp., Schubertella irumensis (Huzimoто), and others in the same pebble, the stratigraphic age is referred to the upper Lower Permian (KANMERA, 1956).

The subcylindrical form of shell, broadly rounded periphery, mode of coiling, almost unfluted septa, and spirothecal structure of the present specimen warrant the generic assignment of this species to Toriyamaia. Judging from shell characteristics and dimension of shell, the present specimen may probably be conspecific with T. laxiseptata KANMERA.

Occurrence:-Rare at Kpp-60. The uppermost part of the $\mathrm{B}_{6}$ zone.

\author{
Family Schubertellidae SkINNER, 1931 \\ Genus Yangchienia LEE, 1933 \\ Yangchienia cfr. compressa (OzAWA) \\ P1. 1, Figs. 6, 7
}

1927. Fusulina (Fusulinella) compressa Ozawa. Jour. Fac. Sci. Imp. Univ. Tokyo, Sec. II. vol. 2, pt. 3, 142-143, pl. 37, fig. 6f; pl. 38, figs. 2b, 16b; pl. 39 , fig. 7 .

1936. Fusulinella compressa Huzıмото. Sci. Rept. Tokyo Bunrika Daigaku, Sec. C, vol. 1, no. 2, p. 40-41, pl. 2, fig. 9 .

1938. Fusulinella compressa Huziмото. Jour. Geol. Soc. Japan, vol. 45, no. 533, p. 275-276, pl. 8, figs. 16-19.

1944. Fusulinella compressa Toriyama. Japan. Jour. Geol. Geogr., vol.19, nos. 1-4, p. 73-74, pl. 6, figs. 10-12.

1957. Yangchienia cfr. compressa KoBayashi. Sci. Rept. Tokyo Kyoiku Daigaku, Sec. C, no. 48, p. 265-266, pl. 1, fig. 17.

1963. Yangchienia compressa Kanmera. Mem. Fac. Sci. Kyushu Univ., Ser. D, Geol., vol. 14, no. 2, p. 90-92, pl. 11, figs. 5-13.

1963. Yangchienia compressa SHeng. Palaeont. Sinica, N.S. B, no.10, p.163164, pl. 4, figs. 20-27.

Material:-Axial section, GK.D 13018 from Kpp-37.

Description:-The available material is too insufficient in number, represented by only a single specimen on which the following description is based.

Shell small and typical fusiform with a straight axis of coiling, straight to gently convex lateral slopes and relatively narrowly pointed poles. Near polar regions lateral slopes of outer volutions slightly concave or irregular. Axial length 
is $1.81 \mathrm{~mm}$ and width is $0.64 \mathrm{~mm}$, giving a form ratio of 2.83 .

Proloculus small and spherical, with outside diameter of about 50 microns. Shell expands slowly and nearly uniformly, but axis extends rather rapidly. Half lengths of the first to seventh volutions are 85, 170,340,475, 610,770, and 900 microns, respectively, and radius vectors of the first to sixth volutions are 41,70 , $105,165,225$, and 325 microns, respectively, resulting in half length-radius vector ratios of $2.07,2.43,3.24,2.88,2.71$, and 2.37 , respectively in the first to sixth volutions.

Spirotheca very thin and consists essentially of a tectum and a lower transparent layer, diaphanotheca, the latter of which is not discernible in parts of inner volutions. The upper surface of tectum and the lower surface of diaphanotheca are partly covered by a very thin dense layer which is analogous to the upper and the lower tectorium of four-layered spirotheca. The thickness of spirotheca in the second to sixth volutions are $9,12,12,15$, and 16 microns, respectively.

Chomata distinct and very thick, with steep tunnel sides and very gentle poleward slopes. Tunnel high and broad, with somewhat irregular path. Tunnel angle is measured $29^{\circ}(?)$ in the sixth volution.

Remarks:-Since the material at our disposal is not sufficient, and only available axial section is not exactly oriented, detailed specific comparison is not advisable here. However, the dimension and important characteristics of shell of the present specimen are almost the same with those of the lectotype specimen of Yangchienia compressa from the Akasaka Limestone and of the same species from the Kozaki Formation, the latter of which has been described at length by KANMERA (1963). SHENG (1963) also described and illustrated Y. compressa from the lower part of the Maokou Limestone in Kwangsi and Kueichow Provinces which show a considerable variation in shell size and development of chomata. In the specimens of $Y$. compressa previously described, the first volution is mostly discoidal or endothyroid, coiling at large angles to the outer volutions. In the Khao Phlong Phrab specimen, however, it is not clearly shown.

Occurrence:-Only at Kpp-37. The upper part of the $\mathrm{B}_{4}$ zone.

\section{Yangchienia haydeni THOMPSON}

Pl. 1, Figs. 8-12

1946. Yangchienia haydeni Thompson. Jour. Paleont., vol. 20, no. 2, p.146-147, pl. 23, figs. 5-11.

1962. Yangchienia cfr. haydeni TiNg. Acta Palaeont. Sinica, vol.10, no. 4, p. 445 , pl. 1, figs. 7-8.

1963. Yangchienia haydeni Sheng. Palaeont. Sinica, N.S.B. no. 10, p.161-162, pl. 5, figs. 10-18.

Material:-Axial sections, GK.D 13475a, 14387, and 13592c from Kpp-611.

Description:-Shell small and inflated fusiform, with narrowly rounded to bluntly pointed poles and a straight axis of coiling. Lateral slopes straight to very gently convex in inner volutions, but straight to slightly concave near the polar regions of outer volutions. Mature shell of eight volutions measures 2.44 to $2.47 \mathrm{~mm}$ in length and $1.18 \mathrm{~mm}$ in width, giving a form ratio of 2.07 to 2.09 . The first volution coils at about $90^{\circ}$ to the axis of outer volutions. The second volution spherical to subspherical, and beyond the third volution the axis extends almost uniformly, and shell takes short fusiform. Ratios of half length to radius vectors of the first 
to eighth volutions in three specimens are $1.03,1.10,1.51,1.84,2.01,2.02,1.96$ and 2.09 , respectively in average.

Proloculus minute and spherical, with outside diameter of 65 and $68(?)$ microns in two specimens. The first three volutions are tightly coiled, and the volutions gradually and uniformly increase in height from the fourth volution to maturity. Radius vectors of the first to eighth volutions in three specimens average $88,132,168,218,297,395,505$, and 620 microns, respectively. Chomata are almost the same in height throughout the length of shell except in inner volutions.

Spirotheca is thin. It is composed essentially of a tectum and a lower less dense layer-diaphanotheca, in the latter of which no minute structure is recognized. The upper surface of tectum and and the lower surface of diaphanotheca are often coated with a thin dense layer in outer volutions except for the last volution. Thus, the spirotheca seems to be composed of four layers. Thickness of spirotheca of the second to seventh volutions in three specimens is $12,13,15,16,17$, and 17 microns, respectively in average.

Tunnel is well developed throughout the growth except for the first volution. Its path is almost straight. Average tunnel angles of the second to seventh volutions in three specimens are $25^{\circ}, 26^{\circ}, 25^{\circ}, 30^{\circ}, 34^{\circ}$, and $35^{\circ}$, respectively. Except in the first volution, chomata are very massive, high and broad, with very steep to almost vertical tunnel side and very gentle poleward slopes. However, it is very characteristic that chomata decrease their height rather abruptly at one-fourth or one-third of the distance from the tunnel to the poles, especially in outer volutions. Height of chomata about a half of chamber height in inner volutions, and a half to two-thirds in outer volutions.

Remarks:-Yangchienia haydeni was originally described by THOMPsoN (1946) from the Bamian Limestone of northern Afghanistan along with Schwagerina furoni THOMPson, Polydiexodina afghanensis THOMPson, Verbeekina verbeeki (GEINITZ), Cancellina primigena HAYDEN, Neoschwagerina craticulifera haydeni DoutKeVITCH and KHABaKov, and Afghanella schencki THOMPson.

Although no well oriented sagittal sections have been available, the Khao Phlong Phrab specimens are identical in essential characteristics of shell to the Afghanistan specimens. The former is, however, a little smaller in size and number of volution than the latter.

Yangchienia haydeni is similar to $Y$. thompsoni SKINNER and WILDE in many respects. Both have chomata which display a marked reduction in height. This sudden change of height of chomata is more conspicuous in $Y$. haydeni than in Y. thompsoni.

Occurrence:-Rare at Kpp-61. The basal part of the $B_{7}$ zone.

\section{Yangchienia tobleri THOMPSON}

Pl. 1, Figs. 13-16

1929. Fusulinella sp. OzAWA and Tobler. Ecol. Geol. Helv., vol.22, no.1, p. $45-49$, pl. 5, fig. 3.

1935. Yangchienia tobleri Thompson. Ecol. Geol. Helv., vol. 28, p. 516-517, pl. 17, fig. 7 (non figs. 1, 2).

1957. Yangchienia tobleri Miklukho-Maklay. Uchen. Zapiski Lgu, Ser. Geol. Nauk, Vyp. 9, p. 103-104, 107, pl. 2, figs. 1, 3, 7.

Material:-Axial sections, GK.D 13520 and 13596 from Kpp-71. 
Description:-Shell relatively large for the genus, and short fusiform, with bluntly pointed poles. Lateral slopes are straight to gently convex. Mature shell of nine volutions is $2.59 \mathrm{~mm}$ in length and $1.32 \mathrm{~mm}$ in width, giving a form ratio of 1.96. The first two volutions are almost spherical and coil at an angle as great as $90^{\circ}$ to the axis of outer fusiform volutions. Beyond the third volution the axis extends polewards gradually and uniformly. Ratios of half length to radius vector in the first to eighth volutions in two specimens average $1.01,0.99,1.29,2.08,2.20$, $2.09,1.97$, and 1.87 , respectively.

Proloculus minute and spherical, having an outside diameter of 70 to 75 microns and a thin structureless proloculus wall of about 9 microns thickness. Shell expands almost uniformly throughout the growth. Radius vectors of the first to ninth volutions in two specimens are $67,109,145,191,257,344,454,570$, and 730 microns, respectively, in average. Chambers are almost the same in height throughout the length of shell.

Spirotheca is thin, consisting essentially of a tectum and a diaphanotheca. However, thin dense layer is observed on the upper surface of tectum and the lower surface of diaphanotheca in parts of outer volutions except for the last one. Combined thickness of tectum and diaphanotheca measured at the thinnest part in the first to ninth volutions in two specimens is $9,12,12,14,15,16,18$, and 19 microns, respecively in average.

Tunnel is narrow and high, with slightly irregular path. Tunnel angles of the fourth to eighth volutions in two specimens are $17^{\circ}-18^{\circ}, 21^{\circ}-23^{\circ}, 23^{\circ}, 24^{\circ}$, and $34^{\circ}($ ?), respectively. Chomata are very massive and well developed except in the first two spherical volutions. They extend from tunnel to pole with nearly undiminished height in inner volutions, but about a half or two-thirds of the distance from tunnel to pole in outer volutions.

Remarks:-Yangchienia tobleri was established by THOMPSON (1935) based on the specimens illustrated by SILvESTRI (1933) as Fusulinella bocki MöLLER came from the Sosio beds of Sicily and the specimen illustrated as OzAWA and TOBLER (1929) as Fusulinella sp. came from the Island of Katakupho, Greece. The latter, an incomplete tangential section was selected by THOMPSON as the "type specimen" of $Y$. tobleri.

Since the "type specimen" is too incomplete to obtain a clear idea of characters of $Y$. tobleri, SKINNER and WILDE (1966b) established Y. thompsoni based on remarkably well preserved specimens came from the Sosio valley, south of Palermo, Sicily. In addition to these specimens they assigned the specimen described by SILVESTRI as Fusulinella bocki MöLLER and those described by THOMPSON as Y. tobleri (pl. 17, figs. 1, 2, non fig. 7) to their new species. Nevertheless, they pointed out that certain differences exist between $Y$. tobleri and $Y$. thompsoni. They mentioned that most obvious of these is the development of the chomata which, in $Y$. tobleri appear to extend with undiminished height nearly to the poles, whereas in $Y$. thompsoni the chomata display a marked reduction in height at about one-fourth of the distance from the tunnel to the poles. This reduction is particularly marked in the outer volutions.

In this viewpoint $Y$. tobleri described by SHENG (1963) from the Maokou Limestone of Desheng, Yishan of Kwangsi, South China is also assigned to $Y$. thompsoni. MikLUKHo-MaKLAY (1957) also described $Y$. tobleri from Crimea. His specimens, though not enough in number, have thick and massive chomata without reduction of height, and are referred certainly to $Y$. tobleri. 
The Khao Phlong Phrab specimens are too insufficient in number to make detailed specific comparison. They are not referable to $Y$. thompsoni but to $Y$. tobleri, having chomata of undiminished height from the tunnel to the poles, although this characteristic is not so clear in the outer volutions.

Occurrence:-Rare at Kpp-71. The lower part of the $\mathrm{B}_{7}$ zone.

\section{Yangchienia thompsoni SKINNER and WILDE}

Pl. 1, Figs. 17-18

1933. Fusulinella bocki Silvestri. Mem. Inst. Geol. R. Univ. Padova, vol. 10, p. 31-32, pl. 2, fig. 7; pl. 3, fig. 6 .

1935. Yangchienia tobleri Thompson (partim). Ecol. Geol. Helv., vol. 28, p. 516517, pl. 17, figs. 1-2 (non fig. 7).

1948. Yangchienia tobleri Thompson. Univ. Kansas Paleont. Contrib. Protozoa, art. 1, pl. 5, figs. 5, 7 .

1963. Yangchienia tobleri Sheng. Palaent. Sinica, N.S. B, no.10, p.162, pl.5, figs. 1-9.

1966. Yangchienia thompsoni SkINNER and WiLde. Univ. Kansas Paleont. Contrib. Paper 8, p. 7-8, pl. 4, figs. 11-12; pl. 5, figs. 1-10; pl. 6, figs.1-4.

Material:-Axial section, GK.D 13825 from Kpp-76.

Description:-Only a single axial section is available on which the following description is based.

Shell small and fusiform, with almost straight to slightly concave lateral slopes and bluntly pointed poles. The axial section of ten volutions is $3.14 \mathrm{~mm}$ in length and $1.50 \mathrm{~mm}$ in width, giving a form ratio of 2.09 . The first two volutions are almost spherical and coiled at about $90^{\circ}$ to the axis of later volutions. Ratios of half length to radius vector of the first to tenth voluions are 1.00, 1.11, 1.35, $2.07,2.13,2,22,2.22,2.10,2.13$, and 2.01 , respectively.

Proloculus small and spherical, with outside diameter of about 70 microns. Shell expands slowly in inner five volutions and more or less rapidly and uniformly in outer volutions. Radius vectors of the first to tenth volutions $72,95,130,170$, $225,295,390,510$ ?, 640 , and 790 microns respectively.

Spirotheca thin and consists of a tectum and a diaphanotheca, but a dense layer is observed inside diaphanotheca and outside tectum especially in the median portion of inner volutions. It is not present at all in the last volution.

Chomata well developed except in the inner spherical two volutions. They are about a half to two-thirds or more as high as chambers. They extend about twothirds or almost of the distance from tunnel to pole in the third to seventh volutions, but about a half of the distance in outer three volutions. Chomata show a remarkable reduction in height, especially in outer two volutions, at about one-third or one-fourth of the distance from tunnel to pole.

Remarks:-Although the material at hand is very much insufficient, the Khao Phlong Phrab specimen is identical in essential characteristics to those of Yangchienia thompsoni of Socio valley of Sicily. The present species resembles Y. tobleri THOMPSON in many respects, but the distinction between these two species was given by SKINNER and WILDE (1966a) in detail as mentioned in the preceding species. The Khao Phlong Phrab specimen shows well the characteristics of chomata and lateral slopes of $Y$.thompsoni - a marked reduction in height especially in outer volutions and straight or slightly concave lateral slopes. The specimens described 
by Sheng (1963) from the Maokou Limestone at Jiuyang, Yishan of Kwangsi as Yangchienia tobleri also show these characteristics.

Occurrence:-Only rarely known at Kpp-76. The middle part of the $\mathrm{B}_{7}$ zone.

Family Schwagerinidae Dunbar and Henbest, 1930

Subfamily Schwagerininae DUNBAR and HenBest, 1930

Genus Schwagerina MöLLER, 1877

Schwagerina cfr. gangpianshanensis SHENG

Pl. 2, Figs. 1-4

1965. Schwagerina gangpianshanensis Sheng. Acta Palaeont. Sinica, vol.13, no. 4 , p. 569, 581, pl. 6, figs. 10-11.

Material:-Axial sections, GK.D 13739, 13744 and 13745 from Kpp-54, and GK.D 13592 from Kpp-61.

Description:-Shell medium to large fusiform, with gently convex to somewhat irregular lateral slopes, and broadly rounded poles. Mature shell of 7 to 8 volutions attains a length of 7.59 to $10.2 \mathrm{~mm}$ and a width of 2.24 to $2.92 \mathrm{~mm}$, giving a form ratio of 2.96 to 3.49 . Inner two to three volutions short ellipsoidal, and from the third or fourth volution axis extends rapidly. Ratios of half length to radius vector of the first to seventh volutions in four specimens 1.92, 2.00, 2.16, $2.38,2.61,2.93$, and 3.03 , respectively.

Proloculus subspherical and medium in size, having outside diameter of 240 $\times 295$ microns in an axial section oriented just through the center of proloculus. Expansion of shell is rapid and almost uniform except in the first volution where shell tightly coils. Radius vectors of the first to seventh volutions in four specimens average $218,303,444,613,838,1119$, and 1315 microns, respectively. Chambers nearly the same in height in median one-third of shell, but gradually increase in height towards poles.

Spirotheca consists of a dense tectum and a fine alveolar keriotheca. Thicknesses of spirotheca of the first to seventh volutions in four specimens $27,30,41$, $43,52,50$, and 62 microns, respectively in average.

Septa the same in structure as spirotheca. Septal fluting intense and somewhat irregular throughout length of shell except for median tunnel area. Septal count unknown. Chomata not present. Tunnel low and narrow in inner volutions but becomes higher and broader in outer volutions. Tunnel angles of the second to fifth volutions in one specimen measure $25^{\circ}, 28^{\circ}, 24^{\circ}$, and $38^{\circ}$, respectively. Axial fillings occur in inner volutions, but not present in outer two to three volutions in most of specimens.

Remarks:-Schwagerina gangpianshanensis was originally described by Sheng (1965) from the Upper Carboniferous Gangpianshan Formation at Gangpianshan and the Lower Permian Eding Formation near Shanzhuling, both in the western part of Hainan Island. SHENG pointed out that S. gangpianshanensis resembles $S$. kumasoana (KANMERA) but differs from the latter in having larger number of volution, more tightly coiled volutions, and smaller proloculus. S. gangpianshanensis also somewhat resembles $S$. laosensis (DEPRAT) but septal fluting is more complicated, the proloculus is smaller, and no axial fillings occur in the latter.

The Khao Phlong Phrab specimens are very similar in important diagnostic 
Table 2. Measurements of Schnagerina cfr. gangpianshanensis ShENG (in mm. unless otherwise stated)

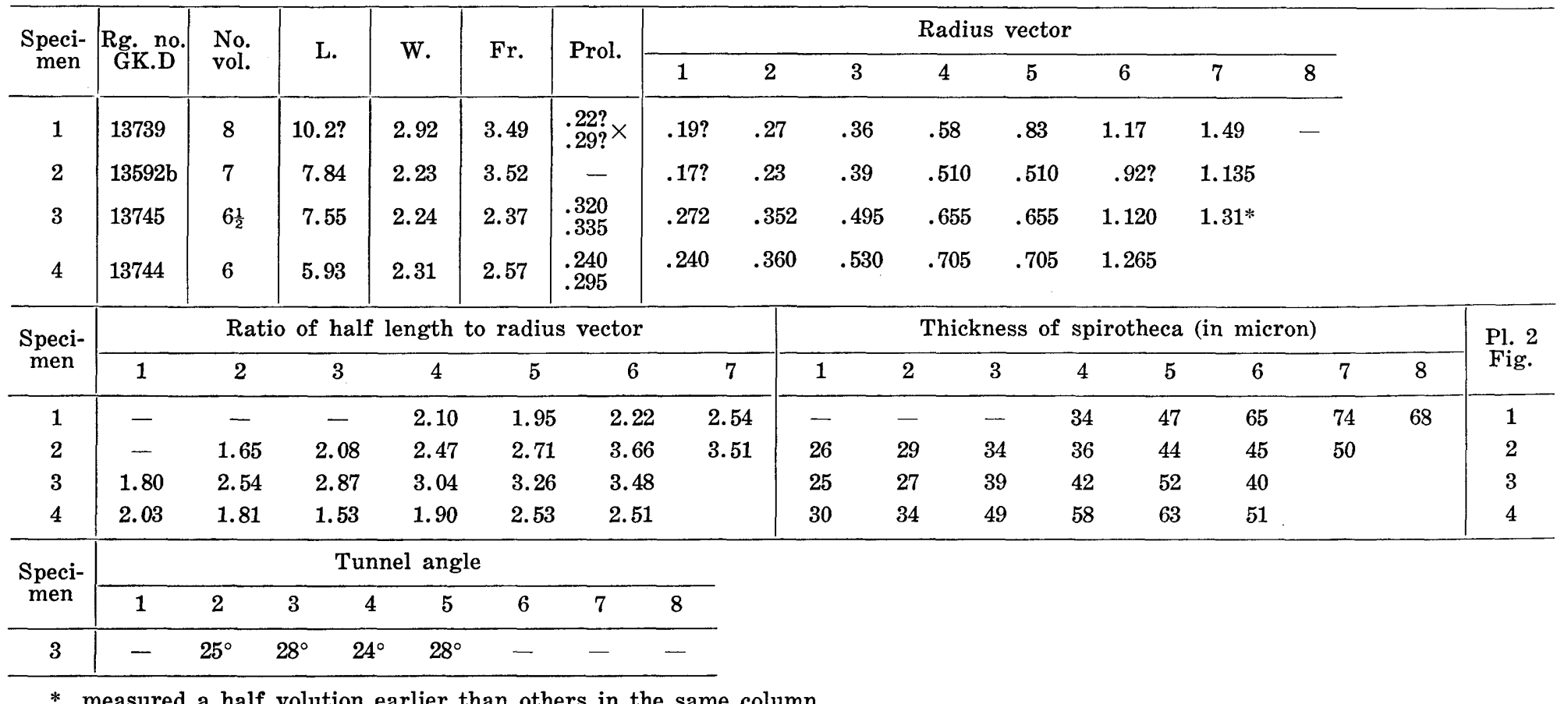

* measured a half volution earlier than others in the same column. 
characteristics to the type specimens from Hainan Island, although the occurrence of axial fillings is generally weak in the former.

Occurrence:-Rare at Kpp-53 and -61 ; common at Kpp-54. The $\mathrm{B}_{6}$ zone.

Genus Pseudofusulina DUNBAR and SkINNER, 1931

\section{Pseudofusulina kueichowensis obesa SHENG}

Pl. 2, Figs. 5-6

1963. Pseudofusulina kueichowensis var. obesa Sheng. Palaeont. Sinica, N.S., B, no. 10, p. 195, pl.16, figs. 3 .

Material:-Axial section, GK.D 13215 from Kpp-21; sagittal section, GK.D 13222 from Kp-21.

Description:- Shell moderate in size, and highly inflated fusiform, with almost straight to slightly concave lateral slopes, and bluntly pointed poles. Only one available axial section (GK.D 13215) of $5 \frac{1}{2}$ volutions $5.00 \mathrm{~mm}$ in length and $3.21 \mathrm{~mm}$ in width, giving a form ratio of 1.56. The first volution nearly spherical. The second volution short fusiform, and beyond the third volution shell assumes nearly the same profile. Ratios of half length to radius vector of the first to fifth volutions in the axial section $1.03,1.31,1.66,1.99$, and 1.73 , respectively.

Proloculus large for the size of shell, and subspherical to irregular rectangular in shape. The largest and smallest diameter in the axial section 385 and 335 microns, respectively. Those of sagittal section 505 and 385 microns, respectively. Proloculus wall considerably thick, having 24 to 27 microns thickness at the thinnest part. Expansion of shell slow in the first half volution, and becomes rapid in the succeeding volutions. Radius vectors of the first to fifth volutions in the axial section $335,495,785,1120$, and 1455 microns, respectively. Those in the sagittal section $336,495,705,1055$, and 1392 microns, respectively.

Spirotheca consists of a tectum and a coarsely alveolar keriotheca. Thickness of spirotheca measured at the thinnest part $24,47,55,79$, and 75 microns, respectively in the first to fifth volutions of axial section, and $24,44,46,52$, and 45 microns in sagittal section.

Septa flute strongly and rather regularly throughout length of shell. Septa not counted with certainty, but approximate number in the second to fifth volutions $18,26,31$, and 34 , respectively.

Chomata not present even in inner volutions. Tunnel indistinct in inner volutions, and low and broad in outer ones with tunnel angles of about $30^{\circ}, 26^{\circ}$ and $29^{\circ}$ in the third to fifth volutions. Axial fillings heavy in all but the last volution. Phrenotheca occurs in a very limited part of outer volutions.

Remarks:-Although the material at hand is not enough, the present specimens well agree in essential diagnostic characteristics with Pseudofusulina kueichowensis obesa described by SHENG (1963) from the Chihsia Limestone at Houziguan near Zisongzheng, Wangmo, Kueichow in association with $P$. kueichowensis SHENG.

The Khao Phlong Phrab specimens slightly differ from the type specimen of SHENG in the development of axial fillings. They are intermediate between $P$. kue $i$ chowensis kueichowensis and $P$. kueichowensis obesa in the occurrence of axial fillings.

Occurrence:-Rare at Kpp-21. The basal part of the $B_{3}$ zone. 


\section{Pseudofusulina regularis (SCHELLWIEN)}

Pl. 2, Figs. 7-8

1898. Fusulina regularis Schellwien. Palaeontographica, vol. 44, p. 250-251, pl. 19, figs. 1-6.

1912. "Fusulina" regularis Deprat. Mém. Serv. Géol. l'Indochine, tome 1, fasc. 3 , p. 28-29, pl. 7, figs. 14-15.

1927. "Fusulina" regularis LEE. Palaeont. Sinica, Ser. B, vol. 4, fasc. 1, p. 5052, pl. 7, figs. 8-10.

1958. Pseudofusulina regularis Kanmera. Mem. Fac. Sci. Kyushu Univ., Ser. D, Geol. vol. 6, no. 3, p. 194-196, pl. 33, figs. 1-10.

1958. Schwagerina regularis TorIYAMA. Mem. Fac. Sci. Kyushu Univ., Ser. D, Geol., vol. 7, p. 140-143, pl. 16, figs. 2-16.

1959. Schwagerina regularis KochANSKY-DevidÉ. Palaeont. Jugoslavica, Sv. 3, p. 24-25, pl. 2, figs. 7-11.

1960. Pseudofusulina regularis SAURin and LÊ-Thi-Vièn. Ann. Fac. Sci. Saigon, p. 396-397, pl. 1, figs. 16-18.

1961. Pseudofusulina regularis MoRIKAWA and Isomi. Geol. Surv. Japan, Rept., no. 191, p. 15-16, pl. 7, figs. 1-10.

1962. Pseudofusulina regularis SUYARI. Jour. Gakugei, Tokushima Univ., Nat. Sci., vol. 12, p. 22-23, pl. 8, fig. 10.

1964. Pseudofusulina regularis SADA. Jour. Sci. Hiroshima Univ., Ser. C, vol. 4, no. 3, p. 257-259, pl. 26, figs. 8-11; pl. 27, figs. 9-10.

1972. Pseudofusulina (Daixina) regularis IGo. Geol. Palaeont. Southeast Asia, vol. 10, p. 105-107, pl. 16, figs. 10-16.

Material:-Axial section, GK.D 13216 from Kpp-21; sagittal section, GK.D 13218 from Kpp-21.

Description:-Shell medium in size and elongate fusiform, with straight, very gently convex or slightly concave lateral slopes and bluntly pointed poles. The axial section of $5 \frac{1}{2}$ volutions has a length of $7.71 \mathrm{~mm}$ and a width of $2.07 \mathrm{~mm}$, with a form ratio of 3.72. The first volution short fusiform. Beyond the second volution axis extends rapidly and shell assumes elongate fusiform with acutely pointed poles. Ratios of half length to radius vector of the first to fifth volutions in the axial section $2.02,3.08,3.34,3.33$, and 3.91 , respectively.

Proloculus large and subspherical in the axial section, with outside diameter of $360 \times 440$ microns, and irregular in the sagittal section with outside diameter of approximately $510 \times 330$ microns. Proloculus wall thin and structureless, with a thickness of 17 to 21 microns. Shell expands very slowly in the first volution, but relatively rapidly in the succeeding volutions. Radius vectors of the first to fifth volutions in the axial section $240,331,512,768$, and 1008 microns, respectively. Those in the sagittal section $214,352,521,752$, and 1040 microns, respectively.

Spirotheca consists of a tectum and a keriotheca. Alveolar structure of keroitheca relatively coarse, with about 4 to 5 alveoli in a distance of 100 microns of spirotheca in the fourth volution. Spirotheca relatively thin in the first volution, but becomes gradually thick. Thickness of spirotheca in the first to fifth volutions $21,22,44$ ?, 55?, and 68? microns, respectively in the axial section, and $21,30,39$, 62 , and 69 ? microns, respectively in the sagittal section.

Septa composed of downward extension of tectum and pycnotheca. Septa strongly fluted throughout length of shell, except for tunnel region where they are plane or fluted weakly. In polar regions fluting extends nearly to tops of 
chambers, forming complicated septal loops. Septal counts of the first to fifth volutions 8 ?, 22?, 29, 30 and 32 , respectively.

Chomata develop very poorly in inner two volutions. Tunnel low and broad, with slightly irregular path. Tunnel angles $36^{\circ}$ in outer two volutions. Phrenotheca appears only in a limited part of the last volution.

Remarks:-Although the Khao Phlong Phrab specimens are not enough in number, their essential diagnostic characteristics well agree with those described by KANMERA (1958) from the Yayamadake Limestone, South Kyushu, Japan, the latter of which, as discussed by him, is identical to the types of the species described by SCHELlwiEn from the Carnic Alps.

The specimens described as Pseudofusulina regularis from Yunnan and Indochina (DEPRAT, 1912), from North China (LEE, 1927), from the Atetsu Limestone, West Japan (SADA, 1964), from the Lake Biwa area (MoRIKAWA and Isomi, 1961), and from Shikoku (SUYARI, 1962) are somewhat different from the Khao Phlong Phrab specimens.

Occurrence:-Rare at Kpp-21. The basal part of the $\mathrm{B}_{3}$ zone.

Pseudofusulina cfr. uenoensis KOBAYASHI

Pl. 2, Figs. 9-12; Pl. 3, Fig. 1

1957. Pseudofusulina uenoensis KoBaYashI. Sci. Rept. Tokyo Kyoiku Daigaku, Sec. C, no. 48, p. 282-283, pl. 4, figs. 1-8.

Material:-Axial sections, GK.D 13467 from Kpp-61, GK.D 13814d and 13821b from Kpp-76, GK.D 13547 and 13557 from Kpp-80; sagittal sections, GK.D 13821a and 13822 from Kpp-76, and GK.D 13552 from Kpp-80.

Description:-Shell moderate to large in size, typical fusiform, with gently convex lateral slopes and bluntly pointed polar ends. Shell of 6 to $6 \frac{1}{2}$ volutions 7.2 to $9.2 \mathrm{~mm}$ in length and 2.8 to $3.1 \mathrm{~mm}$ in width, giving a form ratio of 2.52 to 3.65. The first volution short fusiform, and in succeeding volutions axis extends gradually and uniformly, giving nearly the same axial profile. Average ratios of half length to radius vector of the first to sixth volutions in five specimens 2.03 , $2.42,2.69,2.72,2.87$, and 3.03 , respectively.

Proluculus large and subspherical, ellipsoidal, or more or less irregular in shape, with structureless wall of 23 to 30 microns thickness. Outside diameter measures 370 to 559 microns in the longest and 270 to 393 microns in the shortest, all average 423 microns. Shell expands relatively rapidly and almost uniformly throughout growth. Radius vectors of the first to sixth volutions in seven specimens average $308,456,639,856,1058$, and 1340 microns, respectively.

Spirotheca consists of a tectum and a finely alveolar keriotheca. About 6 alveoli present in a distance of $\mathbf{1 0 0}$ microns of keriotheca. Average thicknesses of spirotheca of the first to sixth volutions in seven specimens $31,36,40,53,69$, and 72 microns, respectively.

Septa the same in structure as spirotheca. Septal fluting intense and somewhat irregular. Tips of fluting reach tops of chamber. Septal counts of the first to sixth volutions in one specimen $8,20,25,26,29$, and 33 , respectively.

Tunnel low and wide, with tunnel angles of $34^{\circ}, 38^{\circ}$, and $41^{\circ}$ in the third to fifth volutions in one of axial section. Chomata indistinct, but in outer volutions of some specimen secondary deposits appear occasionally at one or both sides of tunnel. 
Table 3. Measurements of Pseudofusulina cfr. uenoensis KoBAYAsHI (in mm. unless otherwise stated)

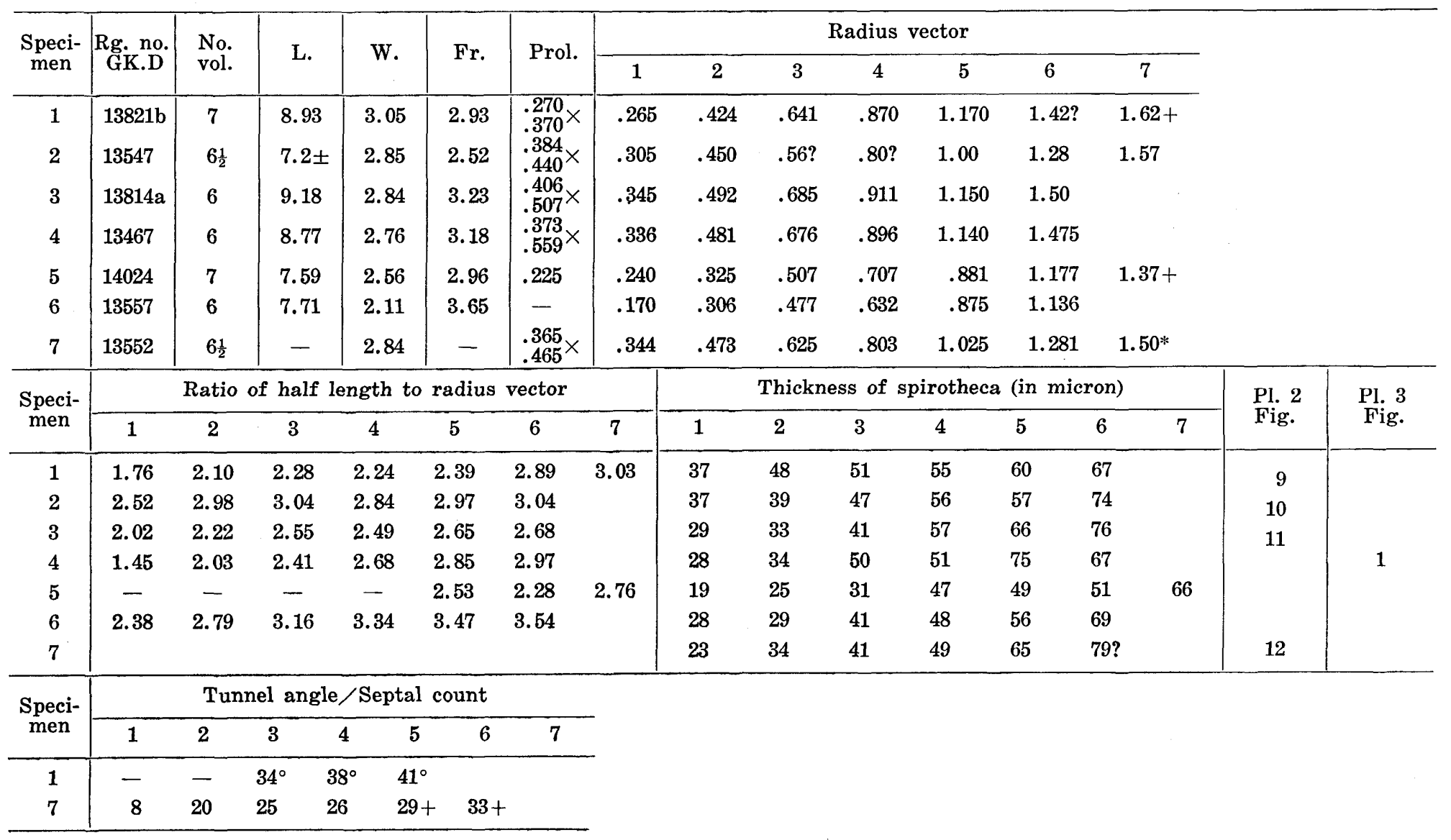


Remarks:-In the shape and dimension of shell, rate of expansion, mode of septal fluting, and other characteristics, the Khao Phlong Phrab specimens most closely resemble Pseudofusulina uenoensis described by KoBAYASHI (1957) from the Ibukiyama Limestone of Central Japan. Although he designated the specimen illustrated as fig. 6 of plate IV as the holotype of the species, the fig. 1 in the same plate is better oriented than the holotype specimen. The specimen of fig. 1 has however no axial fillings.

The Khao Phlong Phrab specimens are different from the types of Ibukiyama Limestone in having weakly developed axial fillings in inner volutions, but the difference is not so distinct as to be separated from the types as a different species. They may be conspecific with each other.

Occurrence:-Common at Kpp-76, rare at Kpp-61 and -80. The uppermost bed of the $B_{6}$ zone to the $B_{7}$ zone.

\section{Genus Parafusulina DUNBAR and SkINNER, 1931}

\section{Parafusulina cfr. elliptica SHENG}

Pl. 3, Figs. 2-6

1915. Fusulina japonica DePrat. Mém. Serv. Géol. l'Indochine, tome 4, fasc. 1, p. 7-8, pl. 1, fig. 18.

1963. Parafusulina elliptica Sheng. Palaeont. Sinica, N.S., B, no. 10, p. 199-200, pl. 18, figs. 9-13.

Material:-Axial sections, GK.D 14099 from Kpp-5, GK.D 13167 from Kpp-7, GK.D 13520 from Kpp-26, GK.D 13934 from Kpp-38, and GK.D 13067 from Kpp-39; sagittal sections, GK.D 13705 from Kpp-5 and GK.D 13121 from Kpp-39.

Description:-Shell moderate and ellipsoidal, with a straight axis of coiling, gently convex lateral slopes and broadly rounded poles. Mature shell of $5 \frac{1}{2}$ to 7 volutions has a length of 5.68 to $6.60 \mathrm{~mm}$ and a width of 2.27 to $3.09 \mathrm{~mm}$, giving a form ratio of 2.39 to 2.50 . The first one to two volutions subspherical to short ellipsoidal, and from the second or third volution axis extends gradually and uniformly. Ratios of half length to radius vector of the first to sixth volutions in four specimens average 1.58, 1.99, 2.24, 2.23, 2.31, and 2.37, respectively.

Proloculus subspherical, ellipsoidal or somewhat irregular in shape, and relatively large, with outside diameter of $290 \times 335$ to $384 \times 528$ microns. Shell expands almost uniformly from the first volution to maturity. Average radius vectors of the first to sixth volutions in six specimens $281,481,598,847,1095$, and 1286 microns, respectively. Chambers nearly the same in height except for polar region where they increase height slightly.

Spirotheca typical in structure for the genus. It is moderately thin, with average thicknesses of the first to sixth volutions in four specimens $19,37,42,50$, 57 , and 56 microns, respectively.

Septa intensely, highly and narrowly fluted throughout length of shell. Septal folds almost reach tops of chamber. Septal counts of the first to fifth volutions in one specimen $9,19,24,26$, and 27 , respectively.

Tunnel relatively low and narrow in inner three or four volutions and more or less widens in outer volutions. Tunnel angles in the first to fourth volutions in one specimen measure $32^{\circ}, 37^{\circ}, 38^{\circ}$, and $38^{\circ}$, respectively. Chomata not present except in the first volution where they are very rudimentary. Secondary deposits fill axial areas of only inner volutions. 
Table 4. Measurement of Parafusulina cfr. elliptica SHENG (in mm. unless otherwise stated)

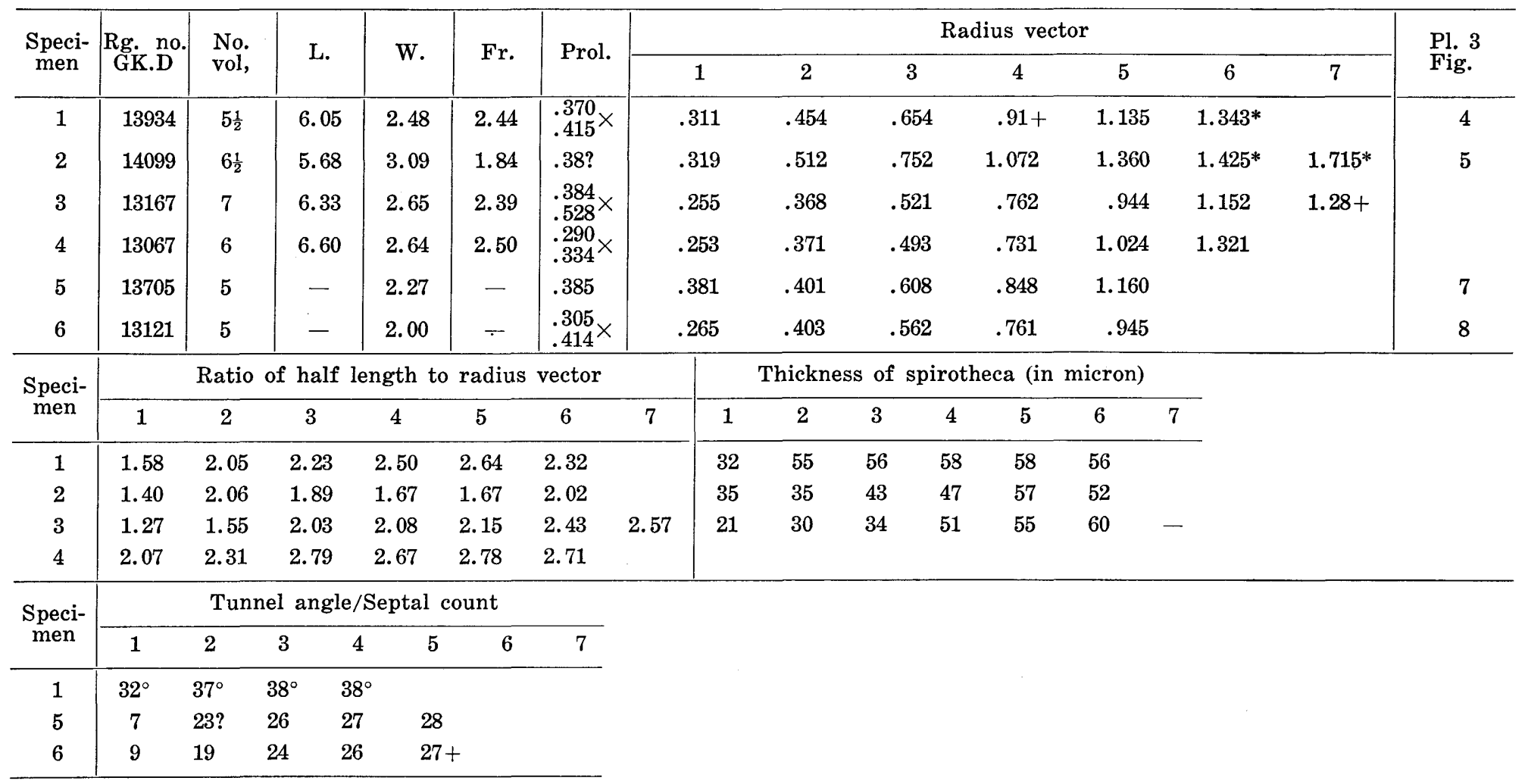

* measured a half volution earlier than others in the same column. 
Remarks:-Parafusulina elliptica was described from the lower part of the Maokou Limestone near Zisongzheng of Wangmo, Kueichow (SHENG, 1963). A specimen illustrated by DEPRAT (1915) as Fusulina japonica was referred by SHENG to this species.

The Khao Phlong Phrab specimens, though not enough in number, are similar to $P$. elliptica in many diagnostic characteristics, especially in shape and dimension of shell and relatively thin spirotheca. They have been tentatively assigned to $P$. elliptica until the final decision can be made on more sufficient material.

Occurrence:-Rare at Kpp-5, -7, -26, -38 , and -39 . The $\mathrm{B}_{2}$ zone to the lower part of the $B_{5}$ zone.

Parafusulina cfr. gruperaensis gruperaensis THOMPSON and MILLER Pl. 3, Figs. 9-14; Pl. 4, Fig. 1

1944. Schwagerina gruperaensis ThOMPson and Miller. Jour. Paleont., vol.18, no. 6, p. 495-496, pl. 79, figs. 1-4.

1960. Schwagerina gruperaensis KLING. Jour. Paleont., vol. 34, no. 4, p.648, pl. 78, figs. 7-10.

1962. Schwagerina gruperaensis Ross. Palaeont., vol. 5, no. 2, p. 301-302, pl. 46, figs. 1-9.

1962. Schwagerina gruperaensis SUXARI. Jour. Gakugei, Tokushima Univ., Nat. Sci., vol. 12, p. 23, pl. 8, figs. 1-3.

1963. Parafusulina (Skinnerella) gruperaensis Kanmera. Mem. Fac. Sci. Kyushu Univ., Ser. D, Geol., vol. 14, no. 2, p. 95-96, pl. 15, figs. 9-13, 14 (?).

1963. Parafusulina gruperaensis Sheng. Palaeont. Sinica, N. S., B, no. 10, p. 197-198, pl. 17, figs. 7-9.

Material:-Axial sections, GK.D 13315 from Kpp-24, GK.D 13090c and 13090d from Kpp-24, and GK.D 13072 from Kpp-39; sagittal section, GK.D 13317 from $\mathrm{Kpp}-22$.

Description:- Shell large and vaulted fusiform, with straight, gently convex or somewhat concave lateral slopes and bluntly pointed poles. A typical specimen of seven volutions (GK.D 13072) about $9.1 \mathrm{~mm}$ in length and $3.4(?) \mathrm{mm}$ in width, giving a form ratio of 2.08. Axial profile of shell nearly the same throughout growth. Ratios of half length to radius vector of the first to sixth volutions in four specimens average 2.06, 2.46, 2.53, 2.52, 2.79, and 2.94, respectively. Proloculus ellipsoidal or irregular. The largest one of kidney form has outside diameter of $392 \times 645$ microns, with structureless wall of 28 microns. Shell expands rapidly and almost uniformly throughout growth. Radius vectors of the first to sixth volutions in four specimens 294, 438,631, 868, 1133, and 1403 microns, respectively.

Spirotheca rather thick, consisting of a tectum and a keriotheca. About $4 \frac{1}{2}$ to 5 alveoli are seen in a distance of 100 microns of keriotheca. Thickness of keriotheca in the first to sixth volutions in four specimens averages $24,32,42,51$, 61 , and 68 microns, respectively.

Septa highly and narrowly fluted throughout length of shell. Chamberlets formed by fluting reach half to three-fourths of, sometimes the same as, height of chambers.

Tunnel low and rather broad, with tunnel angles of $29^{\circ}, 28^{\circ}, 35^{\circ}$, and $45^{\circ}$, respectively in the first, third to fifth volutions in one specimen (GK.D 13072). Dense calcite deposits fill axial regions of inner three to five volutions, spread out 
Table 5. Measurement of Parafusulina cfr. gruperaensis gruperaensis THOMPSON and MILLER

(in $\mathrm{mm}$. unless otherwise stated)

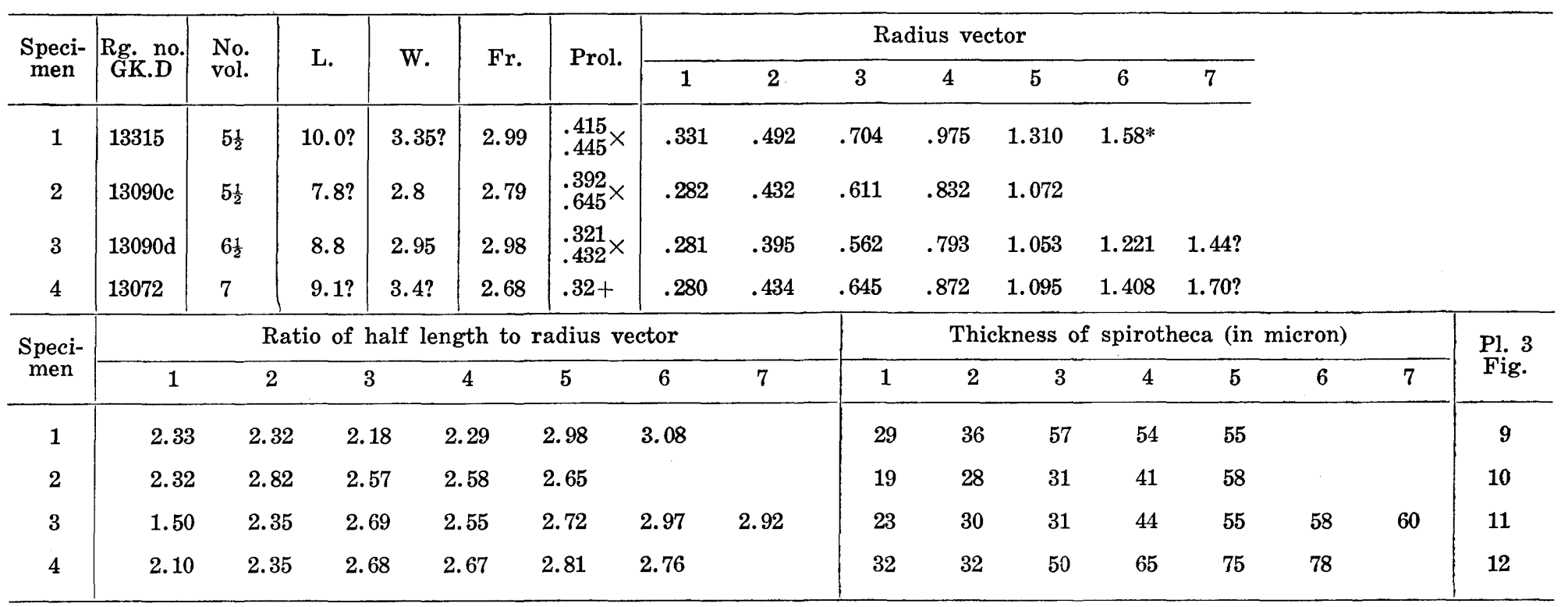

* measured a half volution earlier than others in the same column. 
from poles to proximity of proluculus.

Remarks:-Parafusulina gruperaensis was originally described by THомPSON and MILLER as a species of Schwagerina, but referred to Parafusulina (Skinnerella) by KANMERA (1963) who distinguished $P$. (Skinnerella) from $P$. (Parafusulina) mainly on the difference of shell-shape, especially that of younger stage.

Since no well oriented sagittal nor tangential sections have been available in the Khao Phlong Phrab specimens, it is not known that whether cuniculi occur in them or not. But they are almost identical to $P$. (S.) gruperaensis of the type from Mexico in the form of shell and the occurrence of heavy axial fillings in inner volutions. The Khao Phlong Phrab specimens slightly differ from those of the Kozaki and the Kueichow specimens by having more or less elongate shell.

Occurrence:-Rare at Kpp-18, -22, -24, -26, and -39 . The $\mathrm{B}_{2}$ zone to the basal part of the $B_{5}$ zone.

\section{Parafusulina gruperaensis brevica SHENG}

Pl. 4, Fig. 2

1963. Parafusulina gruperaensis var. brevica SHeng. Palaeont. Sinica, N.S., B, no. 10 , p. 198, pl. 21, fig. 2 .

Material:-Axial section, GK.D 13154 from Kpp-7.

Description:-Only a single axial section is available for this subspecies, on which the following description is based.

Shell of $5 \frac{1}{2}$ volutions moderate in size and nearly regular hexagonal in shape, having a length of $3.33 \mathrm{~mm}$ and a width of $3.03 \mathrm{~mm}$, and a form ratio of 1.08 . The first volution discoidal, the second volution subspherical, and beyond the third volution shell assumes hexagonal axial profile, with almost straight lateral slopes and very broadly rounded poles. Ratios of half length to radius vector of the first to fifth volutions $0.82,1.26,1.27,1.13$, and 1.19 , respectively.

Proloculus relatively large and ellipsoidal, with outside diameter of $240 \times 448$ microns, and a thin proloculus wall of 12 microns. Expansion of shell more or less slow in inner two volutions but becomes rapid and almost uniform in outer volutions. Radius vector of the first to fifth and a half volution $370,471,719,1082$, 1441, and 1740 microns, respectively.

Spirotheca rather than and consists of a tectum and a coarsely alveolar keriotheca. 5 to 6 alveoli present in a distance of 100 microns of keriotheca. Thickness of spirotheca in the first to fifth and a half volutions $13,31,31,41,44$, and 48 microns, respectively.

Septa strongly and rather regularly fluted throughout length of shell. Chamberlets formed by flutings reach about a half to three-fourths of height of chamber. No chomata present. Tunnel high and broad, with tunnel angles of $36^{\circ}$ and $42^{\circ}$ in the third and fourth volution, respectively. Axial fillings occur heavily in inner two volutions, but become less heavy or almost not present in outer volutions.

Remarks:-Although the present material is too insufficient in number, unique hexagonal axial profile of the present specimen warrants the specific identification to Parafusulina gruperaensis brevica described from the lower part of the Maokou Limestone at Houziguan near Zisongzheng, Kueichow. However, the Khao Phlong Phrab specimen is less in number of volution, and less heavy in the axial fillings.

It could be argued that the present specimen may have been compressed in the 
axial direction after the deposition. However, the specimens of Neofusulinella, Misellina and Pseudodoliolina in the same section were affected compressive deformation very few if not all. Therefore the unique axial profile of Parafusulina gruperaenesis brevica is considered to be original, not formed by compression after deposition.

Occurrence:-Only found at Kpp-7. The basal part of the $\mathrm{B}_{2}$ zone.

\section{Parafusulina quasigruperaensis SHENG}

Pl. 4, Figs. 3-4

1963. Parafusulina quasigruperaensis SHENG. Palaeont. Sinica, N.S., B, no. 10, p. 198-199, pl. 17, figs. 10-11.

Material:-Axial sections, GK.D 13549 from Kpp-80, and 14048b from Kpp-82.

Description:-The following description is based on a typical axial section, GK.D 13549. Shell of $6 \frac{1}{2}$ volutions large and thick fusiform, with cylindrical median portion, gently convex, straight or slightly concave lateral slopes, and broadly rounded poles. Axial length $8.2 \mathrm{~mm}$ and width $4.05 \mathrm{~mm}$, giving a form ratio of 2.03. Inner three volutions somewhat irregular short fusiform, and from the fourth volution shell assumes nearly the same in axial profile. Ratios of half length to radius vector of the first to sixth volutions $1.37,1.31,1.38,1.65,1.88$, and 2.01 , respectively.

Proloculus large and irregular in shape, with outside diameter of $592 \times 696$ microns and thin proloculus wall of 19 microns thickness. Shell expands rapidly throughout growth. Radius vectors of the first to sixth and a half volution 621, $803,1030,1307,1581,1920$, and 2120 microns, respectively.

Spirotheca relatively thick and consists of a tectum and a coarsely alveolar keriotheca. Thickness of spirotheca of the first to sixth volutions $33,47,47,59$, 63 , and 78 ? microns, respectively.

Septa strongly and narrowly fluted throughout length of shell. Chamberlets formed by septal flutings about a half to two-thirds as high as chambers in the median portion of shell, and reach almost tops of chambers in polar areas. Septal count unknown because of absence of sagittal section.

Tunnel low and rather narrow, with tunnel angles of $15^{\circ}, 14 ?^{\circ}$ and $22^{\circ}$ in the third to fifth volutions, respectively. Chomata not present. Heavy secondary calcite deposits fill axial regions of inner three volutions.

Remarks:-By its shell shape, large proloculus, rapid expansion of shell, and mode of occurrence of axial fillings, the present specimen is certainly identified to Parafusulina quasigruperaensis described by SHENG from the Maokou Limestone in the vicinity of Pingding, Yishan of Kwangsi and Zisongzheng, Wangmo, Kueichow.

Occurrence:-Rare at Kpp-80 and -82. The upper part of the $\mathrm{B}_{7}$ zone.

\section{Parafusulina yabei HANZAWA}

Pl. 4, Figs. 5-9

1899. Fusulina japonica YABE. Jour. Geol. Soc. Tokyo, vol. 6, no. 68, p. 189-194, text-figs. 1-4.

1903. Fusulina japonica var. YABE. Jour. Geol. Soc. Tokyo, vol. 10, no. 113, p. 1- 
13, pls. 2-3.

1906. Fusulina japonica var. YABE. Jour. Coll. Sci. Imp. Univ. Tokyo, vol.21, art. 5, pl. 2, fig. 1 .

1942. Parafusulina yabei Hanzawa. Japan. Jour. Geol. Geogr., vol. 18, no.4, p. 127-130, pl. 13, figs. 1-4; pl. 14, figs. 1-5.

1958. Schwagerina yabei MoRIKawa. Sci. Rept. Saitama Univ., Ser. B, vol.3, no. 1 , p. 110-111, pl. 15, fig. 9 .

1959. Schwagerina yabei Igo. Sci. Rept. Tokyo Kyoiku Daigaku, Sec. C, vol.6, no. 56, p. 248 , pl. 2 , fig. 8 .

1963. Parafusulina yabei Sheng. Palaeont. Sinica, N.S., B, no. 10, p. 197, pl. 18, figs. 4-8.

Lectotype:-Although HANZAWA did not designate the holotype, only axial section illustrated by him as plate XIV, fig. 1 is automatically the type specimen of the species.

Material:-Axial sections, GK.D 13946, 13948b, 13950, and 13951 from Kpp-38.

Description:-Shell large and ellipsoidal, with straight axis of coiling, gently convex lateral slopes, and broadly rounded poles. Mature shell of 7 volutions 9.05 to $9.62 \mathrm{~mm}$ in length and about 3.7 to $4.26 \mathrm{~mm}$ in width, giving a form ratio of 2.26 to 2.45 . The first two volutions subspherical to short ellipsoidal, and succeeding volutions nearly the same in axial profile. Ratios of half length to radius vector of the first to seventh volutions in the specimen-1 (GK.D 13951) 1.06, 1.51, 1.83, $2.00,2.43,2.45$, and 2.25 , respectively. Those in the specimen-2 (GK.D 13948b) $1.78,2.08,2.09,2.24,2.39,2.42$, and 2.58 , respectively.

Proloculus large and subspherical, with outside diameter of $432 \times 485$ microns in the specimen-2 and about $0.43 ? \times 0.34 \mathrm{~mm}$ in the specimen-1. Expansion of shell more or less slow in inner two volutions, but considerably rapid and almost uniform in outer volutions. Radius vectors of the first to seventh volutions 425 , $592,801,1095,1440,1775$, and 2147 microns in the specimen-1. Those of the first to sixth and a half volutions $321,453,640,850,1120,1460$ ?, and 1620 ? microns, respectively in the specimen-2.

Spirotheca consists of a tectum and a coarsely alveolar keriotheca. About $5 \frac{1}{2}$ to 6 alveoli are observed in a distance of 100 microns of spirotheca in outer volutions. Thickness of spirotheca of the first to seventh volutions in the specimen-1 $42,53,48,60,80,81$, and 79 microns, respectively. Spirotheca shows somewhat rugosity, especially in outer volutions.

Septa intensely and regularly fold throughout length of shell. Chamberlets formed by septal fluting about a half to three-fourths of chamber height, and often reach ceiling of chamber.

Tunnel low and narrow, with tunnel angles of $24^{\circ}, 28^{\circ}, 41^{\circ}$, and $43^{\circ}$ in the first to fourth volutions of specimen-1. Chomata not present. Axial fillings occur in inner four to five volutions.

Remarks:-Although the Khao Phlong Phrab specimens are not enough in number, their important shell characteristics-shell size and form, proloculus size, relatively thin spirotheca, intensity of septal fluting, and mode of occurrence of axial fillings-are identical to those of the original specimen described by HANZAWA (1942) from Tomuro, Tochigi Prefecture, Kwanto massif, Japan. Only difference is that a rugosity of spirotheca has been observed in one of the Khao Phlong Phrab specimen, but this is not shown in the others. It is assumed, therefore, that this is not inherent to the species. 
Sheng (1963) described $P$. yabei from the lower part of the Maokou Limestone of Kwangsi and Kueichow, to which the Khao Phlong Phrab specimens are almost identical in every respect.

Occurrence:-Only found at Kpp-38. The uppermost horizon of the $\mathrm{B}_{4}$ zone.

\section{Parafusulina japonica (GÜMBEL) \\ Pl. 5, Figs. 4-8; Pl. 6, Figs. 1-8}

1878. Fusulina japonica GüMBel. Beil. Z. Dent. u. Öster. Alpenvereins, p. 479.

1883. Fusulina japonica SchwAGER, in RICHTHOFEN's China, vol. 4, p.121-124, pl. 15, figs. 1-11.

1903. Fusulina japonica YABE. Jour. Geol. Soc. Tokyo, vol. 10, p. 6-8.

1906. Fusulina japonica YABE. Jour. Coll. Sci. Imp. Univ. Tokyo, vol. 21, art. 5, pl. 2, fig. 1.

1914. Fusulina japonica Deprat. Mém. Serv. Géol. l'Indochine, tome 3, fasc. 1, p. 7-9, pl. 1, figs. 1-9.

1927. Schellwienia japonica OzAwA. Jour. Fac. Sci. Imp. Univ. Tokyo, vol.2, pt. 3, p. 147-149, pl. 36, figs. 1-7; pl. 37, fig. 7a.

1935. Pseudofusulina japonica GUBLer. Mém. Soc. Géol. France, no. 26, p.90-91, pl. 2, figs. 2, 7 .

1958. Parafusulina japonica Morikawa. Sci. Rept. Saitama Univ., Ser. B, vol. 3, no. 1, p. 112-114, pl. 19, figs. 1-7.

1959. Pseudofusulina cfr. japonica Toriyama and Sugr. Mem. Fac. Sci. Kyushu Univ., Ser. D, Geol. vol. 9, no. 1, p. 24-25, pl. 1, figs. 7-8.

Lectotype:- The axial section illustrated as plate XXXVI, fig. 2 by OzAWA (1927) from the lower part of the Nc zone of the Akasaka Limestone, Central Japan.

Material:-Axial sections, GK.D 13010b, 13014, 13019, and 13079 from Kpp-37, GK.D 13919, 13923, and 13937 from Kpp-38, and GK.D 13965 from Kpp-42; sagittal sections, GK.D 13019, 13078 and 13152 from Kpp-37, GK.D 13925 and 13928 from Kpp-38; tangential section, GK.D 13968 from Kpp-42; and many other sectioned specimens.

Description:-Shell large and typical fusiform, with almost straight axis of coiling, straight to very gently convex lateral slopes and narrowly rounded poles. Mature shell of 6 to 7 volutions 10.0 (?) to $11.96 \mathrm{~mm}$ in length and 2.23 to $3.33 \mathrm{~mm}$ in width, giving form ratios of 3.37 to 3.88 . The first volution subspherical to short fusiform, and from the second volution axis extends rapidly. Ratios of half length to radius vector of the first to seventh volutions in seven specimens 1.80 , $2.21,2.66,2.95,3.21,3.39$, and 3.32 , respectively.

Proloculus relatively large and subspherical to irregular, with outside diameters of 370 to 569 microns, averaging 420 microns in ten specimens. Proloculus wall thin, having a thickness of 16 to 26 microns with average of 23 microns in five specimens. Shell coils tightly in the first volution, but expands relatively rapidly and almost uniformly in the second to the last volution. Average radius vectors of the first to seventh volutions in ten specimens $294,432,595,820,1094,1359$, and 1582 microns, respectively. Chambers nearly the same in height in the median portion of shell, but increase rapidly towards pole.

Spirotheca consists of a tectum and a coarsely alveolar keriotheca. 5 to 6 alveoli present in a distance of $\mathbf{1 0 0}$ microns of spirotheca of outer volutions. Thickness of spirotheca in the first to sixth volutions in ten specimens average 27,34 , 
Table 6. Measurements of Parafusulina japonica (GüMBEL) (in mm. unless otherwise stated)

\begin{tabular}{|c|c|c|c|c|c|c|c|c|c|c|c|c|c|c|c|c|c|c|c|c|c|}
\hline \multirow{2}{*}{$\begin{array}{c}\text { Speci- } \\
\text { men }\end{array}$} & \multirow{2}{*}{$\left|\begin{array}{|c}\text { Rg. no. } \\
\text { GK.D }\end{array}\right|$} & \multirow{2}{*}{\multicolumn{2}{|c|}{$\begin{array}{l}\text { No. } \\
\text { vol. }\end{array}$}} & \multirow{2}{*}{ L. } & \multirow{2}{*}{ W. } & \multirow{2}{*}{ Fr. } & \multirow{2}{*}{ Prol. } & \multicolumn{7}{|c|}{ Radius vector } & \multicolumn{7}{|c|}{ Ratio of half length to radius vector } \\
\hline & & & & & & & & 1 & 2 & 3 & 4 & 5 & 6 & 7 & 12 & 3 & 4 & 5 & & 7 & 7 \\
\hline 1 & 13923 & & $6 \frac{1}{2}$ & 11.12 & 3.33 & 3.37 & .496 & .361 & 1.472 & .625 & .850 & 1.185 & 1.5521 & $1.710^{*}$ & $1.58 \quad 2.24$ & 2.53 & 2.82 & 3.0 & 43 & .14 & 3.37 \\
\hline 2 & 13919 & & $7 \frac{1}{2}$ & 11.3 & $3.2+$ & 3.53 & .375 & .248 & 8.328 & .490 & .665 & .883 & 1.1211 & 1.385 & $2.13 \quad 2.72$ & 2.82 & 2.87 & 2.91 & 13 & .12 & 3.55 \\
\hline 3 & 13965 & 6 & 6 & 11.15 & 3.00 & 3.72 & $.402 \times$ & .288 & 8.425 & .608 & .880 & 1.168 & 1.503 & & $1.84 \quad 2.48$ & 2.60 & 3.07 & 3.56 & 63 & 3.65 & \\
\hline 4 & $13010 \mathrm{~b}$ & & $5 \frac{1}{2}$ & 11.96 & 2.9 & 4.12 & $.35+$ & .304 & 4.491 & .685 & .928 & 1.232 & - & & $2.11 \quad 1.74$ & 2.13 & 2.84 & 3.44 & & & \\
\hline 5 & 13079 & & $6 \frac{1}{2}$ & 11.53 & $3.15+$ & 3.66 & $.360 \times$ & .312 & 2.465 & .626 & .808 & 1.088 & 1.340 & & $1.17 \quad 2.09$ & 2.47 & 2.96 & 3.17 & & 3.84 & \\
\hline 6 & 13937 & $\epsilon$ & 6 & $10.0+$ & 2.72 & 3.68 & $.504 \times$ & .325 & 5.461 & .633 & .820 & 1.091 & 1.320 & & $2.31 \quad 2.63$ & 3.62 & 3.70 & 3.77 & & .79 & \\
\hline 7 & 13014 & 7 & 7 & $9.4+$ & 2.42 & 3.88 & $.387 \times$ & .291 & 1.432 & .525 & .760 & 1.043 & 1.3131 & L.553 & $1.44 \quad 1.60$ & 2.42 & 2.42 & 2.55 & & .82 & 3.03 \\
\hline 8 & 13925 & 7 & 7 & - & 3.06 & - & $.370 \times$ & .294 & 4.433 & .601 & .852 & 1.135 & 1.4411 & .680 & & & & & & & \\
\hline 9 & 13928 & 5 & 5 & - & 2.23 & 一 & $.385 \times$ & & & .592 & .825 & 1.055 & & & & & & & & & \\
\hline 10 & 13152 & & $5 \frac{1}{2}$ & - & 2.36 & - & $.32+$ & .265 & 5.401 & $.56 ?$ & .808 & 1.055 & $1.280^{*}$ & & & & & & & & \\
\hline \multirow{2}{*}{$\begin{array}{c}\text { Speci- } \\
\text { men }\end{array}$} & \multicolumn{6}{|c|}{ Thickness of spirotheca (in micron) } & \multicolumn{7}{|c|}{ Tunnel angle/Septal count } & \multirow{2}{*}{$\begin{array}{c}\text { Pl. } 5 \\
\text { Fig. }\end{array}$} & \multirow{2}{*}{$\begin{array}{c}\text { Pl. } 6 \\
\text { Fig. }\end{array}$} & & & & & & \\
\hline & 1 & 2 & 3 & 4 & 5 & 3 & 1 & 2 & 3 & 4 & 5 & 6 & 7 & & & & & & & & \\
\hline 1 & 35 & 35 & 37 & 40 & 63 & 8 & - & - & - & $21^{\circ}$ & $31^{\circ}$ & $40^{\circ}$ & & 4 & & & & & & & \\
\hline 2 & 28 & 30 & 39 & 43 & 57 & 60 & $36^{\circ}$ & - & $34^{\circ}$ & $43^{\circ}$ & $35^{\circ}$ & $43^{\circ}$ & & 5 & & & & & & & \\
\hline 3 & 31 & 38 & 43 & 67 & 67 & 5 & - & - & - & $38^{\circ}$ & $33^{\circ}$ & $45^{\circ}$ & & 6 & & & & & & & \\
\hline 4 & 23 & 33 & 54 & 77 & 80 & & & & & & & & & & 1 & & & & & & \\
\hline 5 & 25 & 26 & 43 & 56 & 65 & 8 & - & $23^{\circ}$ & $23^{\circ}$ & $27^{\circ}$ & $28^{\circ}$ & $39^{\circ}$ & & & 2 & & & & & & \\
\hline 6 & 31 & 42 & 49 & 59 & 73 & 5 & & & & & & & & & 3 & & & & & & \\
\hline 7 & 27 & 37 & 47 & 73 & 83 & & & & & & & & & & 4 & & & & & & \\
\hline 8 & 22 & 36 & 37 & 49 & 61 & 3 & 8 & 16 & 21 & 23 & 27 & 28 & $33 ?$ & 7 & & & & & & & \\
\hline 9 & 26 & 37 & 45 & 58 & 68 & & 12 & 18 & 21 & 24 & 30 & & & & 7 & & & & & & \\
\hline 10 & 20 & 21 & 27 & 31 & 57 & & 8 & 20 & 22 & 24 & 28 & & & & 8 & & & & & & \\
\hline
\end{tabular}

* measured a half volution earlier than others in the same column. 
$42,55,67$, and 76 microns, respectively.

Septa thin, and the same in structure as spirotheca, being composed of downward deflection of tectum and keriotheca on both sides. Septa strongly and regularly fluted. Cuniculi clearly observable in tangential sections. Chamberlets formed by strong septal fluting about half to three-fourths of the height of chamber, and even reach ceiling of chamber. Septal counts of the first to seventh volutions in three specimens average $9,18,21,24,28,28$, and 33 , respectively.

Tunnel low and broad with somewhat irregular path. Tunnel angles of the first to sixth volutions in four specimens average $36^{\circ}, 23^{\circ}, 29^{\circ}, 32^{\circ}, 32^{\circ}$, and $42^{\circ}$, respectively. Chomata not present. Axial fillings develop only in a narrow zone along axis of inner volutions.

Remarks:-Parafusulina japonica (GüMBEL) has been known widely from the Middle Permian rocks in the eastern part of Tethys, from Karakorum to Japan. However, the diagnostic characteristics of the species are considerably different according to authors, resulting in that quite different specimens have been referred to this species. Thus, as pointed out by KAHLER and KAHLER (1966), the revision is necessary for Parafusulina japonica.

Although GüMBEL introduced the specific name of "Fusulina japonica" in 1878, he did not give any illustration. Later in 1883, ScHWAGER first illustrated "Fusulina japonica" from Tarui, Province Mino where is, however, now conjectured to be Akasaka (FujImoto and ToRIYAMA, 1963). Schwager's fig. 5 of plate $\mathrm{XV}$ is only the axial section which has at least six and a half volution. Although a half of the last volution and polar areas are broken out, this axial section is estimated to have a length of $11.1 \mathrm{~mm}$ and a width of $4.5 \mathrm{~mm}$, with a form ratio of about 2.4. It is noted that no axial fillings occur in this specimen. ScHWAGER also illustrated three free specimens as figs. $2 \mathrm{a}, 2 \mathrm{~b}$ and $2 \mathrm{c}$ in the same plate. As the form ratio of these specimens is 2.18 at $2 \mathrm{a}, 3.18$ at $2 \mathrm{~b}$, and 3.86 at $2 \mathrm{c}$, the specimen of fig. 5 is not typical form for the species, but represents one of the thickest specimens.

OzAWA (1927) described this species from the Akasaka Limestone, and illustrated several well-oriented axial sections, among which fig. 2 of plate XXXVI is considered to be most typical, having a slender fusiform with a form ratio of 2.81 and no axial fillings except for a narrow zone along the axis of inner three to four volutions.

SUYARI (1962) also described the present species from central Shikoku, Japan, and rejected the OZAWA's specimens illustrated as figs. 2, 3, 5, and 6 of plate XXXVI from $P$. japonica. He is of an opinion that the occurrence of axial fillings vary gradually among specimens and regarded as being within a limit of specific variation. Thus, he included several specimens described by ToRIYAMA (1958) as Parafusulina edoensis into $P$. japonica, most of them have rather heavy axial deposits.

Parafusulina japonica is most closely related to $P$. edoensis as mentioned by previous workers. MORIKAWA (1955) considered that the latter may be a junior synonym of the former. Ozawa stated that the former has more slender shell, thicker spirotheca and much heavier axial fillings, while SUYARI mentioned that there is no difference between two species in form ratio and occurrence of axial fillings, and only difference is thicker spirotheca and larger radius vector for the corresponding volution in $P$. edoensis. However, the radius vectors of the lectotype specimen of $P$. edoensis are almost the same with those of the ScHWAGER's axial 
section illustrated as fig. 1 of Plate XXXVI which has more or less heavy axial fillings. Therefore, radius vector for corresponding volution is not a key to distinguish two species.

Based on the discussions above, and to avoid future confusion, it is concluded that the most striking difference between $P$. japonica and $P$. edoensis is thicker spirotheca and occurrence heavy axial fillings in the latter. In $P$. japonica axial fillings do not occur or very weak if exist. Thus defined, the following specimens are considered to be not assignable to $P$. japonica: DEPRAT, 1915, pl. 1, figs. 17-20 ; CoLANI, 1924, pl. 7, figs. 1-30; pl. 8, figs.1-5, 9-13; LEE, 1927, pl.13, figs. 1-8; CHen, 1934, pl. 6, figs. 1, 9, pl. 8, fig. 7; Нuziмото, 1936, pl. 5, figs. 8-10, pl. 6, fig. 3; MoriKaWa, 1955, pl. 14, figs. 11-12; KoBaYASHI, 1957, pl. 6, figs. 3-5; SAKaGAMI, 1958, pl. 3, fig. 3, and SUYARI, 1962, pl. 10, figs. 1-3.

Occurrence:-Abundant at Kpp-37; common at Kpp-38 and -42. The upper part of the $\mathrm{B}_{4}$ and the lower part of the $\mathrm{B}_{5}$ zone.

\section{Parafusulina cfr. sapperi (STAFF) \\ Pl. 5, Figs. 1-3}

1912. Fusulina verneuili var. sapperi StaFf. Palaeontographica, vol. 55, p. 181183, pl. 19, fig. 11 (non pl. 19, figs. 8, 9,13).

1939. Parafusulina sapperi DUNBar. Jour. Paleont., vol.13, no. 3, p. 344-347, pl. 35, figs. 1-6.

1936. Pseudofusulina kaerimizensis Huziмoto. Sci. Rept. Tokyo, Bunrika Daigaku, Sect. C, no. 2, p. 65-67, figs. 6-8; pl. 8, figs. 1-4.

1957. Parafusulina kaerimizensis KoBaYASHI. Sci. Rept. Tokyo Kyoiku Daigaku, Sect. C, no. 48, p. 291-292, pl. 7, fig. 1 .

1957. Parafusulina sapperi KoBAYASHI. ibid. p. 292-293, pl. 6, figs. 6, 7.

1963. Parafusulina (Skinnerella) cf. sapperi KanMERA. Mem. Fac. Sci. Kyushu Univ., Ser. D, Geol., vol.14, no. 2, p. 99-100, pl. 17, figs. 1, 2, 3(?) , 4.

1963. Parafusulina sapperi Sheng. Palaeont. Sinica, N.S., B, no. 10, p. 204, pl. 19, figs. 1-2.

non 1923. "Fusulina" verneuili var. sapperi LEe. Bull. Geol. Soc. China, vol. 2, nos. $3-4$, p. 74-76, pl. 1, figs. 2, 2a.

Material:-Axial sections, GK.D 13214 from Kpp-21 and GK.D 13144 from Kpp-35; sagittal section, GK.D 13022 (immature specimen) from Kpp-35.

Description:- Shell large and elongate fusiform, with straight to gently inflated median portion, gently convex lateral slopes, and narrowly rounded poles. Mature shell of 7 volutions (Specimen-1, GK.D 13214) attains a length of $13.07 \mathrm{~mm}$ and a width of $3.54 \mathrm{~mm}$, with a form ratio of 3.69 . The innermost volution subspherical to short fusiform. Axis extends rapidly in the succeeding volutions. Ratios of half length to radius vector of the first to sixth volutions in the specimen-1 $1.18,2.23,2.35,3.15,3.23$, and 3.36, respectively. Those of specimen-2 (GK.D 13144, not exactly axial) $1.59,2.34,2.32,2.48,2.63$, and 2.77 , respectively.

Proloculus subspherical or ellipsoidal, with outside diameters of $425 \times 550$ and $370 \times 489$ microns, respectively in specimen-1 and -2. Proloculus wall thin and structureless, having 26 microns in thickness. The first volution tightly coiled. From the second volution shell expands rapidly. Radius vectors of the first to sixth volutions $310,437,708,991,1337$, and 1680 (?) microns in specimen-1 and 277,410 , $655,924,1284$, and 1598 microns, in specimen-2, respectively.

Spirotheca relatively thick, consisting of a tectum and a finely alveolar kerio- 
theca. 6 to $6 \frac{1}{2}$ alveoli counted in a distance of 100 microns of keriotheca of outer volutions. Thickness of spirotheca in the first to sixth volutions $31,47,60,82,89$, and 79 microns, respectively in specimen-1 and $42,45,45,55,58,89$, and 79 microns, respectively in specimen-2.

Septa thin, and strongly and narrowly fluted throughout length of shell. Fluting is regular in median portion of shell, but somewhat irregular in polar areas where small septal loops appear. Cuniculi observable.

Chomata not present. Tunnel low and broad, with somewhat irregular path. Tunnel angles of the second to fifth volutions in specimen- 1 measures $30^{\circ}, 39^{\circ}, 39^{\circ}$, and $45^{\circ}($ ?), respectively. Axial fillings present along a narrow zone of inner two to three volutions.

Remarks:-The diagnostic characteristics of Parafusulina sapperi, such as large and elongate fusiform of shell, fairly rapid expansion of volutions, strong and rather regular fluting of septa, and occurrence of axial fillings in inner volutions, are observed in the Khao Phlong Phrab specimens. Compared with the lectotype of the species and also with well oriented axial sections described and illustrated by KANMERA (1963) from the Kozaki Formation, South Kyushu, Japan, the present specimens have slightly thinner spirotheca in outer volutions and no chomata in inner volutions.

LEE (1923) described Fusulina verneuili var. sapperi from Hsing-an-hsien, North Honan, North China, but his specimens may not be referable to the present species, having rather tightly coiled volutions and a smaller size of shell.

Occurrence:-Common at Kpp-35, rare at Kpp-21 and -38. The $\mathrm{B}_{3}$ and $\mathrm{B}_{4}$ zones.

\section{Parafusulina granumavenae (ROEMER) \\ Pl. 6, Figs. 9-10; Pl. 7, Figs. 1-13}

1880. Fusulina granum-avenae Roemer. Palaeontographica, vol. 27, p.4, pl.1, figs. 2a-c.

1896. Fusulina granum-avenae VerbeeK and Fennema. Java et Madoura, pt.1, p. 1131-1133, pl. 1, figs. 1-10.

1925. Fusulina (Schellwienia) granum-avenae Ozawa. Jour. Coll. Sci. Imp. Univ. Tokyo, vol. 45, art. 6, p. 29-30, pl. 6, fig. 6.

1927. Schellwienia granum-avenae OzAWA. Jour. Fac. Sci. Imp. Univ. Tokyo, Sect. II, vol. 2, pt. 3, p. 143-145, pl. 35, figs. 1-6, 8a, 9; pl. 38, fig. 13a; pl. 39, fig. 9.

1935. Pseudofusulina granum-avenae, var. Gubler.. Soc. Géol. France, N.S. 11, fasc. 4, Feuilles 36-57, Mém. 26, p. 92-93, pl. 3, fig. 1.

1936. Pseudofusulina granum-avenae Huziмoto. Sci. Rept. Tokyo Bunrika Daigaku, Sect. C, vol. 1, no. 2, p. 63-65, pl. 7, figs. 3-5.

1956. Schwagerina granum-avenae CHEN. Palaeontologia Sinica, N.S. B, no.6, p. 40-41, pl. 8, figs. 6-10.

1957. Pseudofusulina granum-avenae Kobayashi. Sci. Rept. Tokyo Kyoiku Daigaku, Sec. C, no. 48, 275-276, pl. 3, figs. 5-7.

1958. Pseudofusulina granum-avenae MoRIKAwA. Sci. Rept. Saitama Univ., Ser. B, vol. 3, no. 1, p. 99-100, pl.13, figs. 1-5, 7, 8 .

1962. Pseudofusulina granum-avenae SUYARI. Jour. Gakugei Tokushima Univ., Nat. Sci., vol. 12, p. 27, pl. 7, figs. 10-11.

1966. Parafusulina granumavenae F. \& G. KAHLer. Fossilium Catalogus, I. Animalia, Fusulinida, pars 113, p. 688-689. 
Lectotype:-VERBEEK and FENNEMA's specimen illustrated as plate 8, fig. 8 in 1896.

Material:-Axial sections, GK.D 13300 from Kpp-6; GK.D 14021a and 14025 from Kpp-14; GK.D. 13041 and 13293 from Kpp-29; GK.D 14050 from Kpp-36; GK.D 13068b from Kpp-39; GK.D 13746 from Kpp-54; GK.D 13394 from Kpp-57: sagittal sections, GK.D 13301 from Kpp-6; GK.D $14021 b$ and 14027 from Kpp-14; GK.D 14046 from Kpp-36; GK.D 13737 from Kpp-54.

Description:-Shell large and elongate fusiform, with flat to gently convex lateral slopes and bluntly pointed poles. Mature shell of 7 volutions 12.99 to 15.67 $\mathrm{mm}$ in length and 2.6 (?) to $2.88 \mathrm{~mm}$ in width, giving a form ratio of 4.51 to 6.03 . The first half to one volution subspherical to short fusiform, and in the succeeding volution axis extends rapidly. Ratios of half length to radius vector of the first to sixth volutions in seven specimens average $2.28,3.14,3.28,3.32,3.89$, and 3.43 , respectively.

Proloculus moderate in size for shell size, and spherical to subspherical, with outside diameter of 210 to 496 microns, averaging 350 microns in 13 specimens. Shell expands relatively slowly in inner three volutions, and expansion becomes rapid but almost uniform in outer volutions. Average radius vectors of the first to sixth volutions in thirteen specimens $234,351,511,713,934$, and 1191 microns, respectively. Chambers nearly the same in height in median one-third of shell, but increase in height more or less rapidly towards pole.

Spirotheca moderate in thickness, consisting of a tectum and a finely alveolar keriotheca. 5 to 6 alveoli present in a distance of 100 microns of keriotheca of outer volutions. Average thickness of spirotheca of the first to sixth volutions in ten specimens $22,27,36,50,60$, and 66 microns, respectively.

Septa narrowly and highly fluted throughout length of shell. Fluting reaches tops of chambers but forms closed chamberlets only in lower half to two-thirds of chambers. Septal counts of the first to fourth volutions in four specimens 9, 22, 27 , and 26, respectively in average. No chomata present. Tunnel low and broad with somewhat irregular path. Tunnel angles of the first to fourth volutions in two specimens 31-37, 34-41, 38-51, and 47, respectively. Weak secondary deposits occur in axial areas of inner volutions.

Remarks:-RoEMER $(1880,1881)$ established "Fusulina" granumavenae on a cylindrical form of fusulines collected from the west coast of Sumatra. Furthermore he reported the species again in next year (Jaarboek van hat Mijnwezenm 1881, p. 292, pl. 1, figs. 2a, b, c), but he did not give any microscopic characteristics nor microscopic illustration. VERBEEK and FENNEMA (1896), who examined the fossils of Sumatra, described the species at length and illustrated a good axial section (plate 1, fig. 8) which should be the type specimen of the species.

OzAWA (1927) also described the species from the Akasaka Limestone, giving illustrations of many well oriented sections, which are almost identical with the specimen illustrated by VerbeEK and FenNema. Chen (1956) also described the present species from the Wuhsueh Limestone in Hupei (equivalent of the Maokou Limestone) and distinguished microspheric and megalospheric forms in the species, although the proloculus of his microspheric form is not so small, being about a half of that of megalospheric form. His microspheric form, except a sagittal section illustrated as fig. 11 of pl. 8, may not be in microspheric generation, but is considered to be variation within megalospheric generation.

The Khao Phlong Phrab specimens, though many of them are not fully grown 
Table 7. Measurements of Parafusulina granumavenae (RoEMER) (in mm. unless oterwise stated)

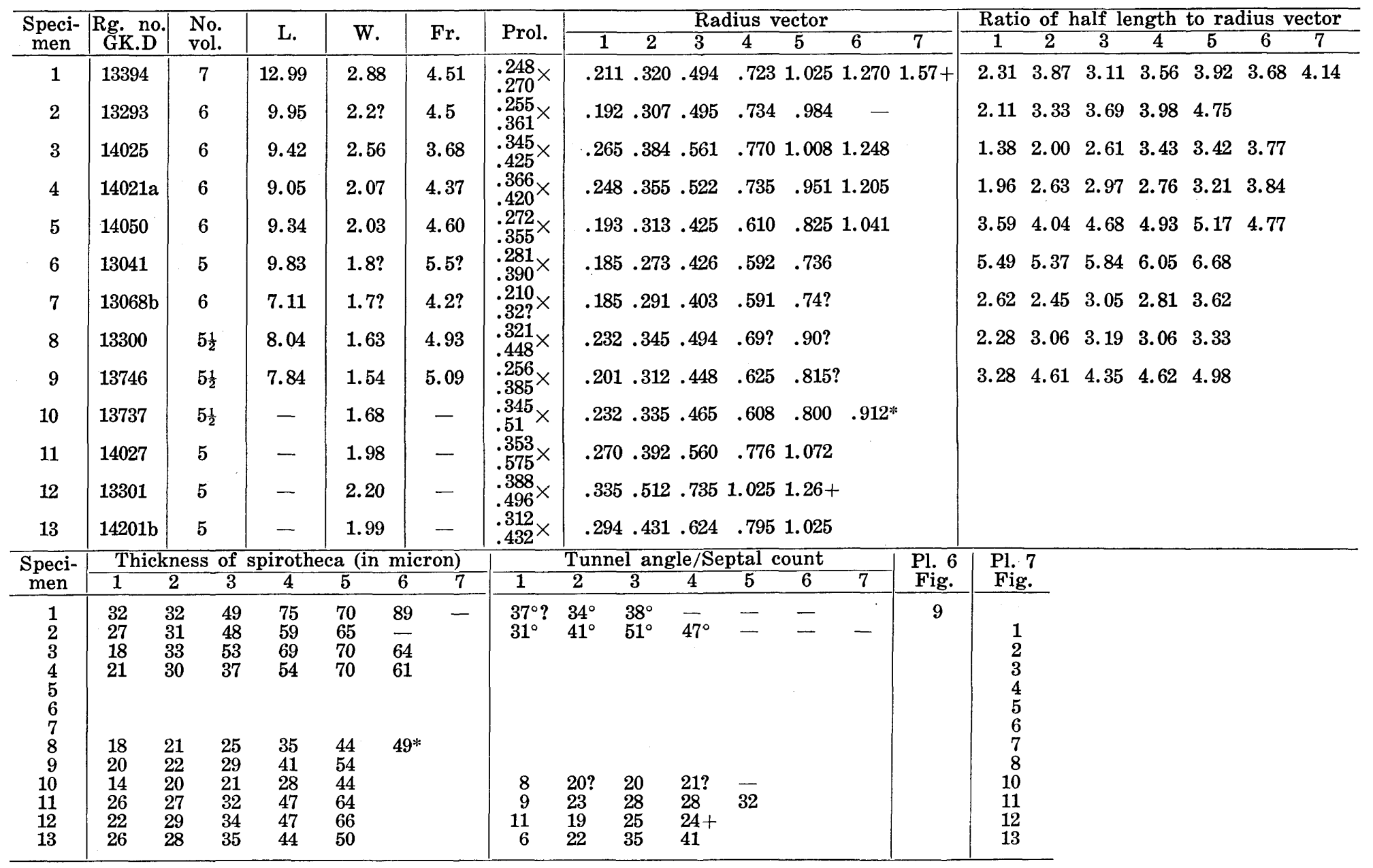

* measured a half volution earlier than others in the same column. 
individuals, are almost the same in essential diagnostic characteristics with the Sumatra and the Akasaka specimens, although the former is more elongate than the latter.

Occurrence:-Common at Kpp-6 and -29 ; rare at $\mathrm{Kpp}-14,-36,-39,-46,-54$, and -57. The $\mathrm{B}_{2}$ to $\mathrm{B}_{6}$ zones.

\section{Parafusulina kaerimizensis (OzAWA) \\ Pl. 8, Figs. 1-8}

1925. Schellwienia kaerimizensis Ozawa. Jour. Coll. Sci. Imp. Univ. Tokyo, vol. 45, art. 6, p. 31-32, pl. 4, figs. 6, 7; pl. 6, fig. 5 (non pl. 4, fig. 5).

1958. Parafusulina kaerimizensis TORIYAMA. Mem. Fac. Sci. Kyushu Univ., Ser. D, Geol., vol. 7, p. 194-197, pl. 30, figs. 6-12; pl. 31, figs. 1-8, pl. 32, figs. 1-9.

1959. Parafusulina kaerimizensis TORIYAMA and SUGI. Mem. Fac. Sci. Kyushu Univ., Ser. D, Geol., vol. 9, no. 1, p. 22, pl. 2, figs. 1-3.

1960. Parafusulina cf. kaerimizensis Pitcher. Brigham Young. Univ. Res. Stud., Geol. Ser. 7, no. 7, p. 28-29, pl. 3, fig. 6.

1961. Parafusulina kaerimizensis Nogami. Mem. Coll. Sci., Univ. Kyoto, Ser. B, vol. 27, no. 3, p. 206, pl. 8, figs. 1-5.

1961. Parafusulina kaerimizensis KaWano. Bull. Fac. Educ. Yamaguchi Univ., Mathem. \& Sci., no. 11, p. 101-103, pl. 8, figs. 11, 12; pl. 9, figs. 1-9; pl.10, figs. 1-3.

1961. Parafusulina cf. kaerimizensis RoBinson. Brigham Young. Univ. Geol. Stud., 8, p. 135-136, pl.19, fig. 12.

1962. Parafusulina kaerimizensis SUYARI. Jour. Gakugei, Tokushima Univ., Nat. Sci., vol. 12, p. 28, pl. 9, fig. 5 .

1963. Parafusulina (Parafusulina) kaerimizensis KANMERA. Mem. Fac. Sci. Kyushu Univ., Ser. D, Geol., vol. 14, no. 2, p.101-102, pl.16, figs. 6, 7; pl. 17, figs. 5-7; pl. 18, figs. 5-8.

Lectotype:-OzaWA's specimen No. II-81, figured as plate 4, fig. 7 (=plate 6, fig. 5) designated by TORIYAMA (1958).

Material:-Axial sections, GK.D 13061 from Kpp-30, GK.D 13141 from Kpp-35, GK.D 13149 and 13081 from Kpp-37, and GK.D 13944 and 13922 from Kpp-38; sagittal sections, GK.D 13006 and 13083 from Kpp-37. Many other specimens are referred to this specis.

Description:-Shell large and elongate fusiform, with straight to slightly bending axis, gently convex lateral slopes, and narrowly rounded poles. Mature shell of 7 volutions 11.3 to $14.2 \mathrm{~mm}$ in length and 2.68 to $3.37 \mathrm{~mm}$ in width, giving form ratio of 4.20. The first one to two volutions short fusiform. From the second or third volution axis extends rapidly polewards. Ratios of half length to radius vector of the first to seventh volutions in six specimens average 2.05, 2.54, 2.91, 2.87, 3.07, 3.49, and 3.84, respectively.

Proloculus large and spherical to subspherical, with outside diameter of 335 $\times 352$ to $425 \times 480$ microns, averaging 386 microns in eight specimens. Proloculus wall thin and structureless, with average thickness of 24 microns in six specimens. Shell expands relatively slowly in the first one to two volutions and more or less rapidly and almost uniformly in the succeeding volutions. Average radius vectors of the first to seventh volutions in eight specimens $268,386,544,767,1030,1321$, and 1592 microns, respectively.

Spirotheca moderate in thickness, consisting of tectum and relatively coarse 
Table 8. Measurements of Parafusulina kaerimizensis (OzAWA) (in mm. unless otherwise stated)

\begin{tabular}{|c|c|c|c|c|c|c|c|c|c|c|c|c|c|c|c|c|}
\hline \multirow{2}{*}{$\begin{array}{c}\text { Speci- } \\
\text { men }\end{array}$} & \multirow{2}{*}{$\begin{array}{r}\text { Rg. no } \\
\text { GK. D }\end{array}$} & \multirow{2}{*}{\multicolumn{2}{|c|}{$\begin{array}{l}\text { No. } \\
\text { vol. }\end{array}$}} & \multirow{2}{*}{ L. } & \multirow{2}{*}{ W. } & \multirow{2}{*}{ Fr. } & \multirow{2}{*}{ Prol. } & \multicolumn{7}{|c|}{ Radius vector } & & \\
\hline & & & & & & & & 1 & 2 & 3 & 4 & 5 & 6 & 7 & & \\
\hline 1 & 13944 & & 7 & $14.2+$ & 3.37 & 4.2 & $.368 \times$ & .304 & .448 & .601 & .880 & 1.135 & 1.440 & 1.729 & & \\
\hline 2 & 13141 & & 8 & 12.59 & $3.0 ?$ & 4.2 & $.328 \times$ & .241 & .335 & .480 & $.69 ?$ & .900 & 1.145 & 1.455 & & \\
\hline 3 & 13922 & & $6 \frac{1}{2}$ & 11.25 & 2.68 & 4.20 & $.425 \times$ & .312 & .416 & .575 & .786 & 1.025 & 1.291 & $1.410^{*}$ & & \\
\hline 4 & 13149 & & 5 & $7.31+$ & $1.75 ?$ & $4.12 ?$ & .352 & .256 & .361 & .480 & $.69 ?$ & - & & & & \\
\hline 5 & 13081 & & $5 \frac{1}{2}$ & 8.73 & 2.48 & 3.52 & $.361 \times$ & .261 & .402 & .575 & .808 & 1.090 & $1 \cdot 41 ?$ & & & \\
\hline 6 & 13006 & & $5 \frac{1}{2}$ & - & 2.12 & - & $.3352 \times$ & .232 & .356 & .525 & .744 & .960 & $1.135^{*}$ & & & \\
\hline 7 & 13083 & & $4 \frac{1}{2}$ & - & 1.60 & - & $\begin{array}{l}.296 \\
.414\end{array}$ & .250 & .375 & .534 & .721 & $.865^{*}$ & & & & \\
\hline \multirow{2}{*}{$\begin{array}{c}\text { Speci- } \\
\text { men }\end{array}$} & \multicolumn{8}{|c|}{ Ratio of half length to radius vector } & \multicolumn{7}{|c|}{ Thickness of spirotheca (in micron) } & \multirow{2}{*}{$\begin{array}{l}\text { Pl. } 8 \\
\text { Fig. }\end{array}$} \\
\hline & \multicolumn{2}{|c|}{1} & 2 & 3 & 4 & 5 & 6 & 7 & 1 & 2 & 3 & 4 & 5 & 6 & 7 & \\
\hline 1 & \multicolumn{2}{|c|}{2.34} & 2.72 & 3.88 & 3.26 & 3.81 & 4.39 & $4.09+$ & 29 & 42 & 42 & 63 & 74 & 79 & 82 & 1 \\
\hline 2 & \multicolumn{2}{|c|}{2.42} & 3.05 & 3.29 & 3.25 & 2.99 & 3.00 & 3.32 & 26 & 35 & 39 & 46 & 49 & 69 & 64 & 2 \\
\hline 3 & \multicolumn{2}{|c|}{1.70} & 2.73 & 3.83 & 2.90 & 2.97 & 3.71 & $4.12^{*}$ & 26 & 28 & 30 & 41 & 48 & 65 & & 3 \\
\hline 4 & \multicolumn{2}{|c|}{2.24} & 2.60 & 3.05 & 3.17 & - & & & 21 & 23 & 28 & 34 & - & & & 5 \\
\hline 5 & \multirow[t]{3}{*}{2.04} & & 2.03 & 2.19 & 2.26 & 2.68 & $3.14 *$ & & 22 & 29 & 41 & 46 & 61 & & & 6 \\
\hline 6 & & & & & & & & & $30 ?$ & 33 & $36 ?$ & 56 & $59 ?$ & & & 7 \\
\hline 7 & & & & & & & & & 25 & 25 & 27 & 50 & 60 & & & 8 \\
\hline \multirow{2}{*}{$\begin{array}{l}\text { Speci- } \\
\text { men }\end{array}$} & \multicolumn{6}{|c|}{ Tunnel angle/Spetal count } & & & & & & & & & & \\
\hline & 1 & 2 & 3 & 4 & $5 \quad 6$ & 7 & & & & & & & & & & \\
\hline 1 & $19^{\circ}$ & $27^{\circ}$ & $29^{\circ}$ & $30 ?^{\circ}$ & $40^{\circ}$ & & & & & & & & & & & \\
\hline 6 & 10 & 21 & 21 & 23 & $26+$ & & & & & & & & & & & \\
\hline 7 & 9 & 19 & 24 & $27+$ & & & & & & & & & & & & \\
\hline
\end{tabular}


alveolar keriotheca. About 5 alveoli present in a distance of 100 microns of keriotheca in outer volutions. Average thickness of spirotheca of the first to seventh volutions in six specimens $25,31,34,48,58,71$, and 73 microns, respectively.

Septa relatively thin and fold intensely and regularly throughout their length except for polar areas. Chamberlets formed of strong fluting of septa nearly to completely reach tops of chamber. Septal counts of the first to fifth volutions in two immature specimens $10,20,22,25$, and 26 (?), respectively.

Tunnel low and narrow, with more or less irregular path. Tunnel angles of the first to fifth volutions in one specimen $19^{\circ}, 27^{\circ}, 29^{\circ}, 30^{\circ}(?)$, and $40^{\circ}$, respectively. Secondary deposits fill chambers from polar extremity to proximity in all but the last one or two volutions.

Remarks:-Parafusulina kaerimizensis (OzAWA) has been well known in the eastern part of Tethys from Karakorum to Japan through Thailand. It is also known in the American Tethys - the Cache Creek Group of British Columbia and Pequop Mountains of Nevada. Since the specific comparison of this species with its allied forms has been discussed in detail by TORIYAMA (1958), NogAMI (1961) and KANMERA (1963), further discussion seems to be not necessary.

The Khao Phlong Phrab specimens are almost identical in the diagnostic characteristics to those from the Atetsu Limestone (NoGAMI, 1961) and from the Kozaki Formation ( KaNMERA, 1963). The specimens described by ToRIYAMA and SUGI (1959) from Muaglek, about $30 \mathrm{~km} \mathrm{NEE} \mathrm{of} \mathrm{Sara} \mathrm{Buri} \mathrm{are} \mathrm{nearly} \mathrm{the} \mathrm{same}$ in shell characteristics with those of Khao Phlong Phrab. Only difference is that the former has a little thicker shell than the latter.

Occurrence:-Abundant at $\mathrm{Kpp}-37$ and -38; common at $\mathrm{Kpp}-30,-34$, and -35; rare at $\mathrm{Kpp}-39$. The $\mathrm{B}_{4}$ zone.

\section{Parafusulina nosonensis THOMPSON and WHEELER Pl. 9, Figs. 1-6}

1946. Parafusulina nosonenis ThOMpson and WheELER. Geol. Soc. Amer. Mem., 17, p. 33-34, pl. 7, figs. 1, 3-5, 7-10, 12 (non figs. 2, 6, 11).

1960. Parafusulina nosonensis Coogan. Univ. Calif. Publ. Geol. Sci., vol. 35, no. 5, p. 264, 269-271, text-fig. 9, pl. 23, fig. 2.

Material:-Axial sections, GK.D 13212b from Kpp-21, GK.D 13024 from Kpp35, and GK.D 14041 and 14048 from Kpp-36, GK.D 13633 from Kpp-46.

Description:-Shell large and highly elongate and cylindrical, with straight to gently curving axis of coiling, flat to slightly irregularly wavy lateral slopes, and bluntly pointed poles. A typical specimen of eight volutions attains a length (double of half length) of $17.1 \mathrm{~mm}$ and a width of $2.52 \mathrm{~mm}$, giving a form ratio of 6.58. The first volution subspheric to short fusiform, and from the second volution axial length increases rapidly with growth. Ratios of half length to radius vector of the first to eighth volutions in five specimens $2.39,3.24,3.79,4.30,4.51$, $5.11,5.60$, and 6.10 , respectively.

Proloculus moderate in size for size of shell, with spherical shape. Outside diameter varies from $209 \times 345$ to $387 \times 469$ microns, with an average of 335 microns for five specimens. Proloculus wall thin, having a thickness of 21 microns. Shell expands slowly in the first two to three volutions, and less slowly and almost uniformly in succeeding volutions. Average radius vector of the first to eighth 
Table 9. Measurements of Parafusulina nosonensis THOMPSON and WHEELER (in mm. unless otherwise stated)

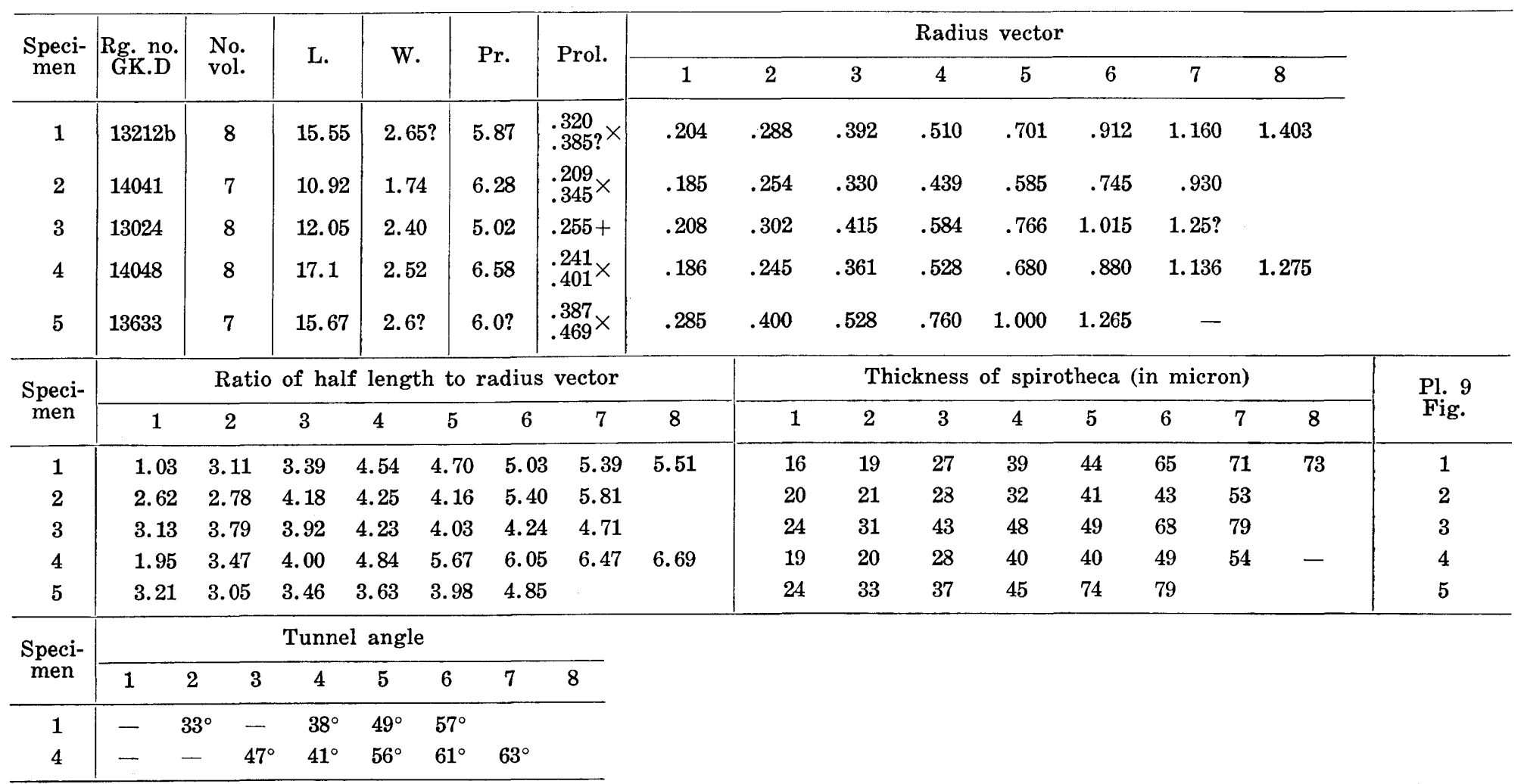


volutions in five specimens $214,298,405,564,746,963,1119$, and 1339 microns, respectively.

Spirotheca consists of a tectum and a keriotheca with fine alveoli. It is rather thin for the size of shell. Average thickness of spirotheca of the first to seventh volutions for five specimens $21,25,33,41,50,61$, and 64 microns, respectively.

Septa highly and narrowly fluted throughout length of shell. Chamberlets formed by flutings about a half to two-thirds as high as chamber. Septal count unknown due to absence of exactly oriented sagittal section.

Tunnel low and broad, with irregular path. Tunnel angles of the third to seventh volutions in one specimen measure $47^{\circ}$ ? $, 41^{\circ}, 56^{\circ}, 61^{\circ}$, and $63^{\circ}$, respectively. Chomata not present. Secondary deposits occur in narrow zone along axis of inner volutions.

Remarks:-Parafusulina nosonensis was originally reported by THoMPSON and WHEELER from the bed 180 feet above the base of the Nosoni Formation of the Guadalupian age in Northern California. One axial and two sagittal sections in their original illustration (figs. 2, 6, and 11 of plate 7) were transferred by CooGAN (1960) to Parafusulina virga THOMPSON and WHEELER with which $P$. nosonensis occurs.

The Khao Phlong Phrab specimens, though not sufficient in number, show important features of the present species - highly elongate shell, rather slow expansion, thin spirotheca, and low septal flutings. Only difference between the Khao Phlong Phrab and the Nosoni specimens is that the former has more elongate shell than the latter.

Occurrence:-Abundant at $\mathrm{Kpp}-36$; common at $\mathrm{Kpp}-21$, and rare at $\mathrm{Kpp}-35$ and -46 . The $B_{3}$ to $B_{5}$ zones.

\section{Genus Monodiexodina SosnINA, 1956}

\section{Monodiexodina sp.}

Pl. 10, Figs. 1-6

Material:-Axial (slightly tangential) section, GK.D 13033; axial sections of immature specimens referred to this species with a query, GK.D 13284, 13040, 13050, 13291, and 13031. All from Kpp-29.

Description:-The following description is based on the specimen of GK.D 13033.

Shell $10.15 \mathrm{~mm}$ in length and $1.45 \mathrm{~mm}$ in width, with a form ratio of 7.00 . Shell highly elongate cylindrical with flat median portion and bluntly pointed poles. The first volution subspherical, and thereafter axis extends very rapidly. Ratios of half length to radius vector of the first to fourth volutions $1.49,2.75,3.58$, and 5.01, respectively.

Proloculus nearly spherical with outside diameter of about $0.29 \times 0.31 \mathrm{~mm}$. Expansion of shell rather slow, with radius vectors $215,321,465,608$, and 750 (?) microns, respectively in the first to fifth volution.

Spirotheca thin, consisting of a tectum and a finely alveolar keriotheca. Thickness of spirotheca of the first to fourth volutions $25,35,40$, and 57 microns, respectively. Septal fluting seems to be regular and confined to lower part of septa at least in median portion of shell, and becomes irregular and high in polar areas. Axial deposits fill chambers of axial zone not completely. 
Although the above description is not sufficient to fix the specific characteristics, the present specimen is assignable to the genus Monodiexodina with certainty. As a species of the genus, the present specimen seems to be relatively small, and not comparable with any species previously known.

Occurrence:-Only found at Kpp-29. The lower part of the $\mathrm{B}_{4}$ zone.

Subfamily Chusenellinae KAHLER and KAHLER, 1966

Genus Chusenella HsU, 1942, emend. CHEN, 1956

Chusenella cheni SKINNER and WILDE

Pl. 10, Figs. 8-12

1966. Chusenella cheni SkINNER and Wilde. Univ. Kansas Paleont. Contrib., Paper 4, pt. 5, p. 33, pl. 25, figs. 1-6.

Material:-Axial sections, GK.D 13294 from Kpp-29, GK.D 13127 from Kpp-39, and GK.D 13616 and 13622 from Kpp-46.

Description:-Shell small and short fusiform, with straight axis of coiling, gently convex lateral slopes and narrowly rounded poles. Mature shell of $6 \frac{1}{2}$ to 7 volutions 3.60 to 4.2 ? $\mathrm{mm}$ in length and 1.42 to $1.75 \mathrm{~mm}$ in width, giving a form ratio of 2.17 to 2.96. The first volution subspherical to short fusiform. From the second volution axis extends gradually and uniformly. Ratios of half length to radius vector of the first to seventh volutions in four specimens $2.06,2.39,2.46$, $2.79,2.61,2.35$, and 2.68 , respectively in average.

Proloculus small and spherical with outside diameter of 145 to 191 microns. Expansion of shell slow in iner two to two and a half volutions, and moderately rapid and uniform in succeeding volutions. Chamber nearly the same in height from pole to pole. Average radius vectors of the first to seventh volutions in four specimens $117,162,239,321,472,663$, and 753 microns, respectively.

Spirotheca thin, consisting of a tectum and a moderately coarse keriotheca. About 4 to $4 \frac{1}{2}$ alveoli observed in a distance of 100 microns of keriotheca in outer volutions. Average thickness of spirotheca of the first to seventh volutions in four specimens $14.5,16,18,24,29,41$, and 38.5 microns, respectively.

Septa almost plane in inner tightly coiled volutions. In succeeding two volutions septa fold more or less strongly throughout length of shell. Septal flutings more than a half to two-thirds as high as chambers. In outermost volution flutings reach nearly tops of chamber. Septal counts unknown.

Chomata present in inner two to three volutions, but they are rudimentary, being only very low deposits on the spirotheca. Tunnel low and narrow with tunnel angles of $13^{\circ}, 22^{\circ}$, and $18^{\circ}$ in the fifth to seventh volutions in one specimen. Heavy secondary deposits nearly fill chambers in narrow zone along axis.

Remarks:-The diagnostic characteristics of the Khao Phlong Phrab specimens are nearly identical to those of Twin Lake area, northwestern Washington, described by SKINNER and WILDE (1967), although the latter is slightly larger and slightly more slender than the former.

Occurrence:-Rare at Kpp-29, -39, and -46. The $\mathrm{B}_{4}$ and $\mathrm{B}_{5}$ zones. 
Table 10. Measurements of Chusenella cheni SkINNER and WILDE (in mm. unless otherwise stated)

\begin{tabular}{|c|c|c|c|c|c|c|c|c|c|c|c|c|c|c|c|}
\hline \multirow{2}{*}{$\begin{array}{c}\text { Speci- } \\
\text { men }\end{array}$} & \multirow{2}{*}{ Rg. no. } & \multirow{2}{*}{$\begin{array}{l}\text { No. } \\
\text { vol. }\end{array}$} & \multirow{2}{*}{ L. } & \multirow{2}{*}{ W. } & \multirow{2}{*}{ Fr. } & \multirow{2}{*}{ Prol. } & \multicolumn{7}{|c|}{ Radius vector } & & \\
\hline & & & & & & & 1 & 2 & 3 & 4 & 5 & 6 & 7 & & \\
\hline 1 & 13294 & $6 \frac{1}{2}$ & 3.60 & 1.52 & 2.37 & .191 & .135 & .183 & $.24 ?$ & .336 & .495 & .682 & $.801^{*}$ & & \\
\hline 2 & 13616 & 7 & $3.8 \pm$ & $1.6 \pm$ & 2.38 & $.145 ?$ & .121 & .171 & .224 & .312 & $.415 ?$ & $.56 ?$ & $.72 ?$ & & \\
\hline 3 & 13127 & 7 & $3.8 \pm$ & 1.75 & 2.17 & $.16 ?$ & .115 & .160 & .256 & .359 & .560 & .800 & & & \\
\hline 4 & 13622 & 7 & $4.2 \pm$ & 1.42 & 2.96 & 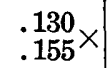 & .095 & $.135 ?$ & $.185 ?$ & .276 & .416 & .608 & .785 & & \\
\hline \multirow{2}{*}{$\begin{array}{c}\text { Speci- } \\
\text { men }\end{array}$} & \multicolumn{7}{|c|}{ Ratio of half length to radius vector } & \multicolumn{7}{|c|}{ Thickness of spirotheca (in micron) } & Pl. 10 \\
\hline & 1 & 2 & 3 & 4 & 5 & 6 & 7 & 1 & 2 & 3 & 4 & 5 & 6 & 7 & Fig. \\
\hline 1 & 1.30 & 1.81 & 2.06 & 2.34 & 2.13 & 2.12 & $2.30 *$ & 14 & 15 & 18 & 18 & 20 & 21 & & 7 \\
\hline 2 & 2.35 & 2.65 & 2.76 & 2.60 & 2.93 & 2.43 & 2.56 & 15 & 16 & 17 & 26 & 34 & 34 & 33 & 9 \\
\hline 3 & 2.52 & 2.70 & 2.51 & 3.25 & 2.60 & 2.20 & & 15 & 17 & 20 & 26 & 45 & 59 & & 10 \\
\hline 4 & - & - & 2.51 & 2.95 & 2.78 & 2.66 & 2.79 & 14 & 17 & 18 & 27 & 27 & 51 & 44 & 11 \\
\hline
\end{tabular}

* measured a half volution earlier than others in the same column. 
1963. Chusenella schwagerinaeformis SHENG. Palaeont. Sinica, N.S., B, no. 10, p. 211, pl. 23, figs. 1-6.

1958. Dunbarinella sp. A, Toriyama. Mem. Fac. Sci. Kyushu Univ., Ser. D, Geol. vol. 7, p. 125-126, pl. 13, figs. 21-22.

1964. Chusenella aff. schwagerinaeformis SADA. Jour. Sci. Hiroshima Univ., Ser. C, vol. 4, no. 3, p. 253-254, pl. 27, figs. 11-13 (non pl. 24, figs. 18-19).

Material:-Axial sections, GK.D 13316 from Kpp-22 and GK.D 13046 from Kpp-29; sagittal section, GK.D 13289 from Kpp-29.

Description:-Shell moderate in size, short fusiform with slightly curving axis of coiling. Lateral slopes gently convex in inner volutions, but they change to more or less concave near pole in outer volutions, forming a little inflated polar areas. Dimension of shell $5.17 \mathrm{~mm}$ and $2.15 \mathrm{~mm}$ in the specimen-1 (GK.D 13316) and $6.15 ? \mathrm{~mm}$ and $2.38 \mathrm{~mm}$ in the specimen-2 (GK.D 13046), with form ratios of 2.41 and 2.58, respectively. The first volution short fusiform, the second and third volutions elongate fusiform thereafter extension of axis becomes gradually less rapid. Ratios of half length to radius vector of the first to seventh volutions 2.44 , $2.65,3.05,3.03,2.70,2.52$, and 3.4 , respectively in the specimen-1, and $2.02,2.98$, $3.25,2.93,2.81,2.38$, and 2.16 , respectively in the specimen-2.

Proloculus small and spherical or subspherical, with outside diameter of 143 and $95 \times 150$ ? microns in the specimen-1 and -2 . Shell tightly coils in inner three volutions, but expands rapidly and almost uniformly in succeeding volutions. Radius vectors of the first to seventh volutions in the specimen-1 160, 215, 285, 436, 661, 970, and 1243 microns, respectively. Those in the specimen-2 94, 144, 201, 305, 448, 685, and 1055 microns, respectively. Chamber about the same in height from pole to pole.

Spirotheca consists of a tectum and a finely alveolar keriotheca. Thickness of spirotheca of the first to seventh volutions $16,21,22,22,28,39$, and 92 microns, respectively in the specimen-1 and $13,13,19,27$ ?, 44?, 58?, and 66 ? microns, respectively in the specimen-2.

Septa highly and regularly fluted throughout growth except in the first one or two volutions where they are weakly fluted or nearly plane. Chamberlets formed by strong flutings reach tops of chamber except in equatorial portion. Septal counts of the first to sixth volutions $9,14,16,17,27$, and 31 , respectively.

Chomata developed in all but the last volution. Tunnel low and narrow, with more or less irregular path. Tunnel angles of the third to sixth volutions 18, 25, 29 , and 35 , respectively.

Remarks:-Although the Khao Phlong Phrab specimens are insufficient in number, their important characteristics are almost the same to those of Chusenella schwagerinaeformis described by SHENG (1963) from the Maokou Limestone near Pingding, Yishan of Kwangsi, except that chomata develop even in outer volutions in the former.

As mentioned in the following species, C. schwagerinaeformis closely similar to C. alpina (KOCHANSKY-DeviÉ and RAMOVS), and differences between these two species are not so distinct that they may probably be regarded as two subspecies within one species. However, more detailed comparison basèd on more sufficient materials is necessary before the final decision is given.

Occurrence:-Rare at Kpp-22, -29 and -35. The $\mathrm{B}_{3}$ and $\mathrm{B}_{4}$ zones. 
Chusenella cfr. alpina (KocHANSKY-DEVIDÉ and RAMOVŠ)

Pl. 10, Figs. 16-18

1955. Dunbarinella alpina Kochansky-DevidÉ and RAmovš. Slovenska Akad. Znanosti in Umetnosti, Rasprave III, p. 380, pl. 2, figs.9-10, pl. 2, figs. 1-6.

1963. Chusenella alpina StewART. Jour. Paleont., vol. 37, no.6, p.1162-1163, pl. 158, figs. 6,10 .

Material:-Axial sections, GK.D 13604 from Kpp-71, GK.D 13810 from Kpp75; sagittal section, GK.D 13825 from Kpp-76.

Description:-Shell moderate in size and inflated fusiform, with gently convex lateral slopes and bluntly pointed poles. Mature shell of 8 to 9 volutions 4.98 to $5.20 \mathrm{~mm}$ in length and $2.3( \pm)$ to $2.79 \mathrm{~mm}$ in width, with a form ratio of 1.79 to 2.26. Compared with expansion of shell axis extends considerably rapidly in inner four volutions. Thus, shell assumes elongate fusiform in inner four volutions. Ratios of half length to radius vector of the first to eighth volutions in one specimen (GK.D 13604, specimen-1) 3.18, 3.13, 3.36, 3.48, 3.19, 2.66, 2.27, and 2.06, respectively. Those of the first to ninth volutions of the other (GK.D 13810, specimen-2) $2.54,2.55,2.83,2.57,2.38,2.23,1.97,1.71$, and 1.52 , respectively.

Proloculus small and spherical, with outside diameter of 80 to 175 microns. Shell tightly coils in inner three to four volutions, but more loosely expands in succeeding volutions. Radius vectors of the first to eighth volutions in three specimens average 113, 166, 238, 336, 477, 667, 954, and 1218 microns, respectively. Chambers nearly the same in height from pole to pole.

Spirotheca consists of a tectum and a keriotheca. About 5 alveoli observed in a distance of 100 microns of keriotheca. Thickness of spirotheca increases gradually as shell grows, averaging $12.5,17,20,26,30,43,59$, and 78 microns, respectively in the first to eighth volutions in three specimens.

Septa thin, and relatively narrowly spaced. Septal counts of the first to eighth volutions in only available sagittal section 9 ?, 11 ?, 12, 17, 22, 25, 28, and 32, respectively. Septal fluting narrow and high in all but the first volution where it is relatively weak. Chamberlets formed by fluting about a half to two-thirds as high as chamber in equitorial portion of shell, but reach tops of chamber in polar areas.

Chomata present in inner four to five volutions, with steep tunnel side and gentle poleward slopes. Tunnel angles of the second to sixth volutions in specimen-1 $30^{\circ}, 30^{\circ}, 26^{\circ}, 27^{\circ}$ ?, and $28^{\circ}$, respectively. Heavy secondary deposits fill polar areas of all but the first volution.

Remarks:-Chusenella alpina was described by KoCHANSKY-DEVIDÉ and RAMovš (1955) under the genus Dunbarinella from the Neoschwagerina limestone near Bled and Bohinjska Bela, Julian Alps, Yugoslavia, to which the Khao Phlong Phrab specimens are closely similar in many essential characteristics. As the original authors mentioned that this species has very small proloculus and a considerably thick spirotheca in outer two volutions, and chomata only in the juvenarium. In the Khao Phlong Phrab specimens, the proloculus is a little larger, the spirotheca is thinner, and the chomata relatively well developed in inner few volutions.

C. alpina is closely similar to C. schwagerinaeformis described by SHENG (1963) from the Maokou Limestone near Pingding, Yishan, Kwangsi, South China. Although the former is distinguished from the latter in having a little smaller 
proloculus, thicker spirotheca, less numerous septa for corresponding volutions, and less inflated polar area, these difference are not so distinct that they may probably be conspecific with each other or regarded as subspecies in one species.

Occurrence:-Rare at Kpp-71, -75, and -76. The $\mathrm{B}_{7}$ zone.

\section{Chusenella? chihsiaensis (LEE)}

Pl. 11, Figs. 1-11

1931. Schellwienia chihsiaensis LEE. Bull. Geol. Soc. China, vol.10, p. 287-288, pl. 1, figs. 2, 2a.

1934. Pseudofusulina chihsiaensis Chen. Palaeont. Sinica, Ser. B, vol. 4, fasc. 2, p. 74-75, pl. 9, figs. 1-8; pl. 9, fig. 18; pl. 11, fig. 10; pl.14, figs. 11-12.

1960. Pseudofusulina chihsiaensis SAURIN et LÊ-ThI-Vik̀n. Ann. Fac. Sci. Saigon, p. 293, pl. 1, fig. 19.

1963. Schwagerina? cf. chihsiaensis Kanmera. Mem. Fac. Sci. Kyushu Univ., Ser. D, Geol., vol. 14, no. 2, p. 93-94, pl. 19, fig. 14.

1963. Chusenella chihsiaensis Stewart. Jour. Paleont., vol. 37, no.6, p.1162, pl. 158, figs. 2,4 .

Lectotype:-Fig. 2 of plate 1 of LEE (1931) designated by KANMERA (1963) and STEWART (1963) as the lectotype of the species.

Material:-Axial sections, GK.D 13061 and 13063 from Kpp-30, GK.D 13918 from Kpp-38, GK.D 13132 from Kpp-39, GK.D 13606 and 13624 from Kpp-46, GK.D 13574 from Kpp-55, GK.D 13424 from Kpp-57, and GK.D 13826 from Kpp-76; sagittal section, GK.D 13054 from Kpp-30.

Description:-Shell moderate in size and slender fusiform, with nearly straight axis of coiling and bluntly pointed poles. Lateral slopes gently convex or nearly flat but become slightly concave in polar areas of outer volutions. Mature shell of 7 to 8 volutions 5.44 to $6.58 \mathrm{~mm}$ in length and 1.60 to $1.83 \mathrm{~mm}$ in width, giving form ratios of 3.32 to 3.68 with an average of 3.49 in six specimens. The first volution short fusiform, and from the second volution extension of axis very rapid but becomes less rapid in outer two to three volutions. Ratios of half length to radius vector of the first to seventh volutions in six specimens average $2.93,3.57$, $4.02,3.78,3.71,3.45$, and 3.42 , respectively.

Proloculus small and subspherical with outside diameter of $88 \times 115$ to 132 $\times 189$ microns, averaging 136 microns in seven specimens. Shell tightly coils in inner three to four volutions, and expands almost uniformly in outer three to four volutions. Average radius vectors of the first to seventh volutions in eight specimens $93,132,185,263,398,604$, and 821 microns, respectively. Chambers nearly the same in height from pole to pole.

Spirotheca thin and consists of a tectume and a keriotheca. Alveoli of keriotheca relatively coarse, with 4 to $4 \frac{1}{2}$ alveoli in a distance of 100 microns of keriotheca. Average thickness of spirotheca of the first to seventh volutions in six specimens $13,15,19,24,34,46$, and 53 microns, respectively.

Septa thin and relatively widely spaced. Septal counts of the first to eighth volution in one specimen (GK.D 13054) 10 ?, 11?,13, 17, 21, 22?, 27, and 28, respectively. Septa almost plane in inner two to three volutions. In outer volutions septa fold throughout length of shell, but fluting is confined to lower half of septa.

Chomata present in the middle stage of growth, being absent about in the first two and the last one or two volutions. They are low, less than a half to one-third 
Table 11. Measurements of Chusenella ? chihsiaensis (LEE) (in mm. unless otherwise stated)

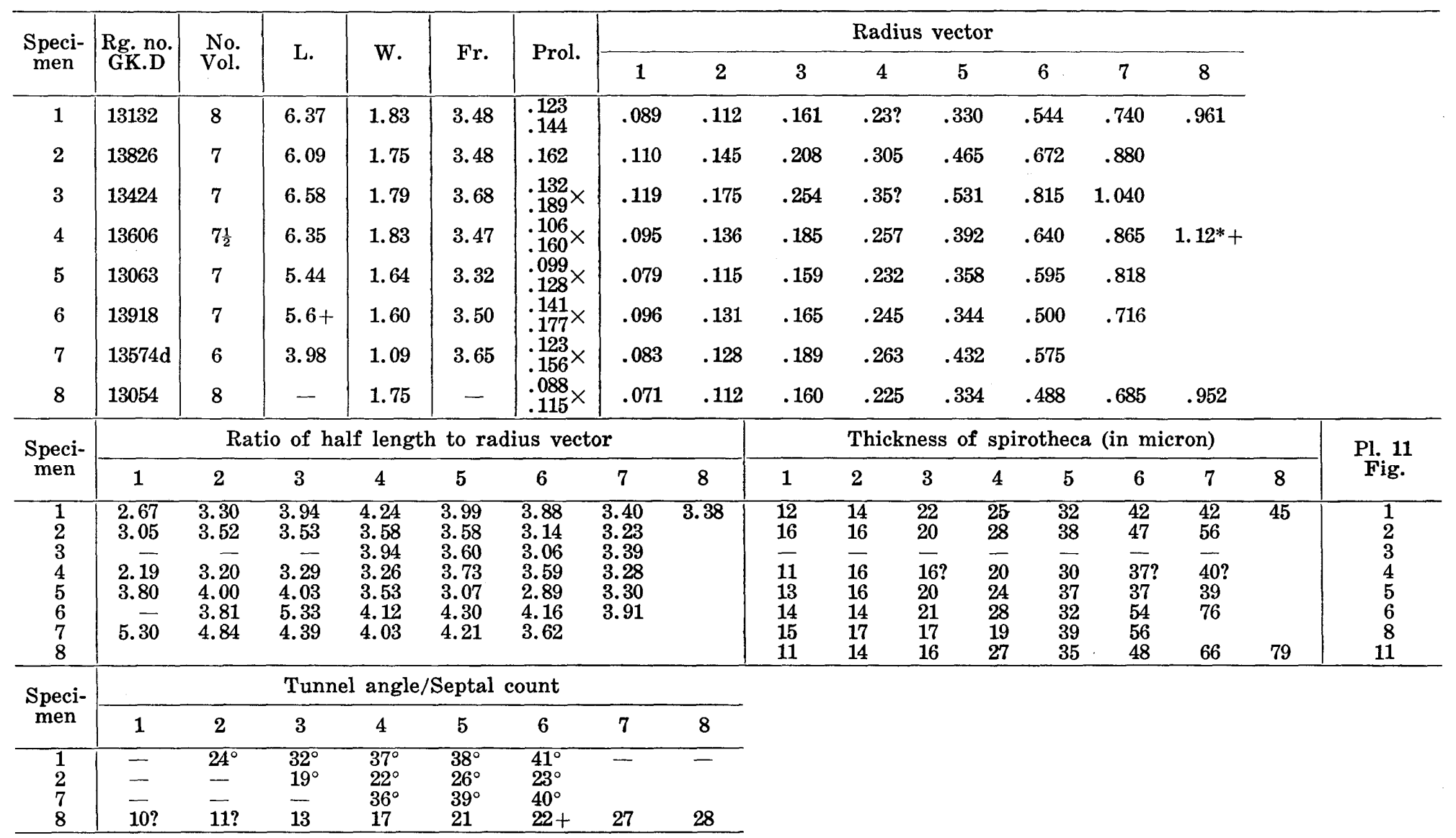

\footnotetext{
* measured a half volution earlier than others in the same colums.
} 
as high as chamber. Tunnel low and wide with irregular path. Tunnel angles of the second to sixth volutions in a typical axial section (GK.D 13132) $24^{\circ}, 32^{\circ}, 37^{\circ}$, $38^{\circ}$, and $41^{\circ}$, respectively. Heavy secondary deposits fill a narrow zone along axis in all volutions.

Remarks:-There is a considerable diversity of opinion among previous workers as the generic assignment of the present species. CHEN, REICHEL, MIKLUKHoMAKLAY, SAURIN et LÊ-THI-VIÈN, and KAHLER and KAHLER referred the present species to the genus Pseudofusulina, whereas ERK and KANMERA (with a query) to the genus Schwagerina. STEWART who summarized all the species of Chusenella previously described along with several new species, assigned chihsiaensis to Chusenella.

The Khao Phlong Phrab specimens are characterized by the tightly coiled inner volutions with acutely pointed poles, small proloculus, thin spirotheca, unfluted septa in inner volutions, presence of chomata in the middle stage of growth, and distinct axial fillings in a narrow zone along the axis. By these features, the present species is not referable to Schwagerina nor to Pseudofusulina, but, at the same time, some of the features mentioned above, especially the presence of chomata make a generic assignment of the present species to Chusenella somewhat questionable. At present the present species is placed in Chusenella with a query. It seems necessary to make clear the range and variation of important diagnostic characteristics of the genus Chusenella and the phylogenetical relationship not only of Chusenella to related genera, but also among the species of Chusenella.

Occurrence:-Fairly abundant at Kpp-30; common at Kpp-38 and -46; rare at $\mathrm{Kpp}-39,-55,-57,-75$, and -76 . The $\mathrm{B}_{4}$ to the lower half of the $\mathrm{B}_{7}$ zones.

\section{Chusenella tenuis Toriyama and Kanmera, n. sp.* Pl. 11, Figs. 12-18}

Material:-Holotype, GK.D 13631 from Kpp-46; Paratypes; axial sections, GK.D 13136 from Kpp-39, GK.D 13583 from Kpp-61 and GK.D 13534a from Kpp-71; sagittal section, GK.D 13592 from Kpp-61.

Description:-Shell moderate in size and slender fusiform, with almost straight axis of coiling, flat to very gently convex lateral slopes, and sharply pointed poles. The holotype specimen of 7 volutions $6.17 \mathrm{~mm}$ in length and $1.28 \mathrm{~mm}$ in width, giving a form ratio of 4.82 . The innermost volution short fusiform, and from the second volution axis extends very rapidly. Rate of extension of axis becomes less rapid in outer two or three volutions in some specimens including the holotype. Ratios of half length to radius vector of the first to sixth volutions in four specimens $2.27,3.10,3.88,3.78,3.83$, and 3.98 , respectively.

Proloculus small and subspherical, with outside diameter of $112 \times 145$ to $145 \times 174$ microns, averaging 140 microns in four specimens. Wall of proloculus 9 to 12 microns. Shell very tightly coils in inner three volutions, and thereafter moderately and almost uniformly in outer volutions. Average radius vectors of the first to sixth volutions in four specimens $92,123,177,258,391$, and 565 microns,

\footnotetext{
* The biostratigraphic study on the Khao Phlong Phrab section has been carried out by R. Toriyama, K. Kanmera, Sa-ngob Kaewbaidhoon, and A-ngoon Hongnusonthi. Micropaleontologic descriptive works on the Khao Phlong Phrab fusuline fauna has been mostly done by R. TORIYAMA and partly by K. KANMERA. Accordingly, R. TORIYAMA and K. KANMERA are responsible for the establishment of the new species in this paper.
} 
Table 12. Measurements of Chusenella tenuis ToRIYAMA and KANMERA, n. sp. (in mm. unless otherwise stated)

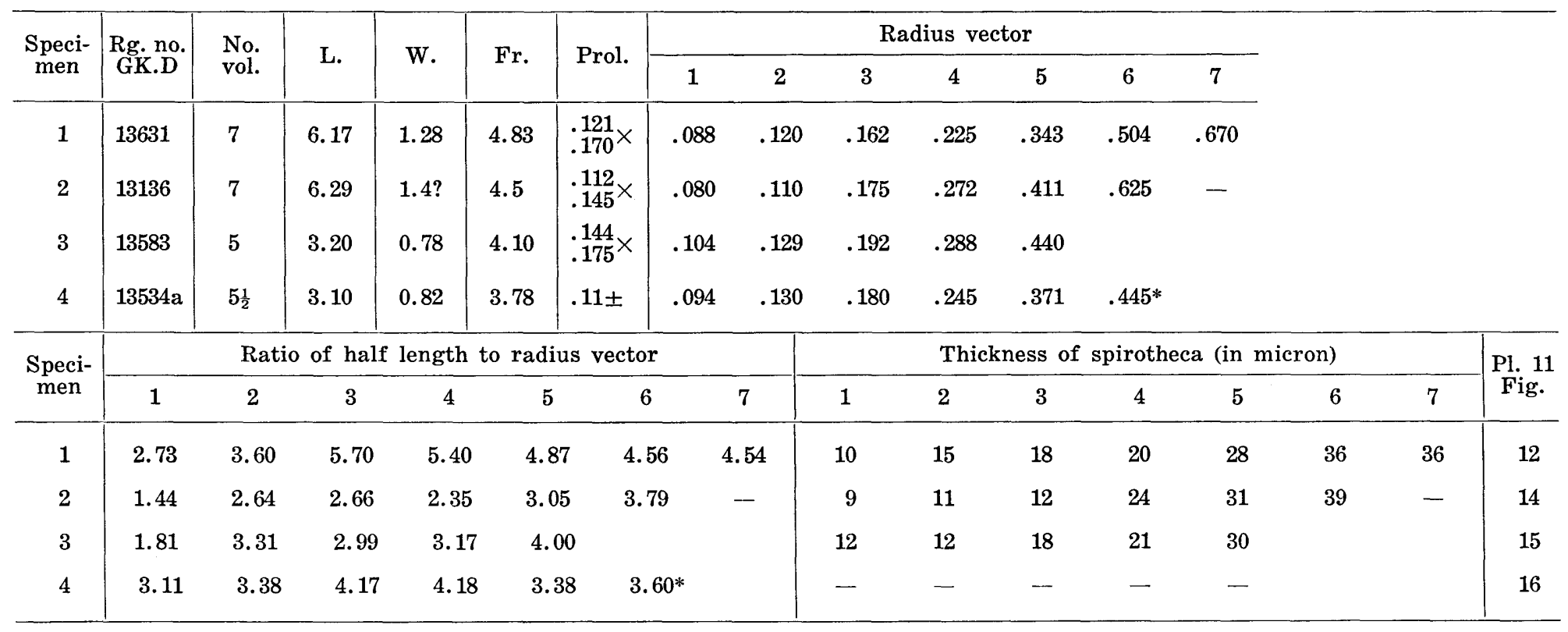

* measured a half volution earlier than others in the same column. 
respectively. Chambers almost the same in height except for polar areas where they slightly increase in height.

Spirotheca thin and consists of a tectum and a finely alveolar keriotheca. About 5 alveoli are observed in a distance of 100 microns of keriotheca of outer volutions. Thickness of spirotheca of the first to sixth volutions in three specimens averages $10,13,16,22,30$, and 38 microns, respectively.

Septa thin and the same in structure as spirotheca. Septa plane in inner three to four volutions, and weakly fluted in polar areas of succeeding one or two volutions. In the last one or two volutions septal fluting reaches tops of chamber in polar areas, but is limited to the lower portion of septa in median portion, where chamberlets formed by septal flutings are about a half to two-thirds as high as chambers.

Chomata developed in outer volutions except the last one, being low and asymmetrical with steep tunnel sides and gentle poleward slopes. Tunnel low and broad with nearly straight tunnel path. Tunnel angles of the third to seventh volutions in the holotype specimen measured $44^{\circ}, 50^{\circ}, 52^{\circ}, 50^{\circ}$, and $54^{\circ}$, respecively. Secondary deposits occur in very narrow zone along axis almost throughout growth.

Remarks:-Although the present material at hand is not enough, its shell features are so characteristic to establish a new species.

The present species resembles Chusenella atetsuensis described by SADA (1964) from the Rugosofusulina arctica subzone (the lower part of Pseudoschwagerina zone) of the Atetsu Limestone, Southwest Japan. The former is distinguished from the latter in having more slender shell, larger proloculus, and more conspicuous chomata in outer volutions. The present species is somewhat similar to C. cibolensis described by STEwART (1963) from the Middle Permian Cibolo Formation of Texas, but differs from the latter in having smaller shell, fewer number of volution, much thinner spirotheca, and better developed chomata.

SADA (1964) discussed in some detail the phylogenetic relationsihp between $C$. atetsuensis and its allied forms, and suggested that $C$. atetsuensis may be an ancestor of a species group including $C$. cibolensis STEWART, C. alpina pristina (KochansKy-DeVIDÉ), and C. tieni (CheN). From the phylogenetic point of view, the present species is somewhat more advanced than $C$. atetsuensis, and may be regarded as a direct descendant of the latter.

Occurrence:-Rare at Kpp-39, $-46,-57,-61$, and -71 . The $\mathrm{B}_{5}$ to the lower half of the $\mathrm{B}_{7}$ zone.

\section{Chusenella sp. A}

Pl. 11, Fig. 19

\section{Material:-Axial section, GK.D 13186 from Kpp-10}

Description:-Only a single axial section has been available for Chusenella sp. A. Shell small and slender fusiform, with straight to very gently convex lateral slopes and sharply pointed poles. Shell of eight volutions $5.28 \mathrm{~mm}$ in length and $1.30 \mathrm{~mm}$ in width, with a form ratio of 4.06 . First volution short fusiform and from the second volution extension of axis very rapid but becomes less rapid in outer three volutions. Ratios of half length to radius vector of the first to eighth volutions $1.88,2.19,3.43,5.02,4.92,3.71,3.16$, and 3.41 , respectively.

Proloculus small and subspherical, with outside diameter of $105 \times 152$ microns. Expansion of shell very slow in inner four volutions, and becomes relatively rapid 
and uniform in outer volutions. Radius vectors of the first to seventh volutions $80,128,175,225,305,481$, and 705 microns, respectively. Chamber height nearly the same from pole to pole.

Spirotheca consists of a tectum and a finely alveolar keriotheca, although its minute structure is not clearly discernible in inner volutions. Spirotheca thin in inner volutions, and moderate in thickness in outer volutions. Thickness of spirotheca of the first to seventh volutions $14,14,22,28,29,41$, and 49 microns, respectively.

Septa seems to be plane in inner volutions, but fluted relatively strongly in outer volutions. Septal fluting about a half to two-thirds as high as chambers in median portion of shell, but reaches almost tops of chamber in polar areas.

Chomata present in inner volutions, although they are very incipient in development, being very low and broad with gentle slope. Tunnel low and wide with somewhat irregular path. Tunnel angles $34^{\circ}$ in third and fourth volutions. Heavy secondary deposits occur in axial zone from pole to proximity of proloculus.

Remarks:-Since the present species is represented by only a single axial section, detailed specific comparison is not advisable. However, Chusenella sp. A. is somewhat similar to C. chihsiaensis (LEE) in many of shell characteristics, from the latter the present species is distinguished by having more slender form and sharply pointed poles. C. chihsiaensis occurs in stratigraphically higher zones in the Khao Phlong Phrab section, whereas the present species is found in the lowest part of the section.

Occurrence:-Rare at Kpp-10. The $\mathrm{B}_{1}$ zone.

Chusenella? sp. B

Pl. 11, Figs. 20-22

Material:-Axial sections, GK.D 13240 from Kpp-22, GK.D 13716 from Kpp-23, and GK.D 13118c from Kpp-39.

Description:-Shell small and inflated fusiform, with straight to curving axis of coiling and narrowly rounded poles. Shell of 6 to $6 \frac{1}{2}$ volutions attains a length of 2.95 to $3.90 \mathrm{~mm}$ and a width of 1.09 to $1.14 \mathrm{~mm}$, with a form ratio of 2.71 to 3.42. Shell assumes fusiform axial profile throughout growth. Average ratios of half length to radius vector of the first to sixth volutions in three specimens 2.31 , $2.87,3.13,3.37,3.23$, and 3.31 , respectively.

Proloculus small and subspherical, with outside diameter of $120 \times 130$ to $142 \times 196$ microns. The first two volutions very tightly coil, and the succeeding volutions expand relatively rapidly and uniformly. Average radius vectors of the first to sixth voltuions in three specimens 100, 136, 195, 269, 408, and 561 microns, respectively. Chambers nearly the same in height in median portion of shell but become somewhat high polewards.

Spirotheca moderately thin, consisting of a tectum and a keriotheca. About $4 \frac{1}{2}$ alveoli are observed in a distance of 100 microns of keriotheca of outer volutions. Thickness of spirotheca of the first to sixth volutions 13, 13, 18, 25, 31, and 54 microns in one specimen. That of the first to fifth in another specimen 16, 19, 20,28 , and 40 microns, respectively.

Septa plane in inner one to two volutions and somewhat strongly flute in outer volutions, although rather weak in median portion of shell. Septal flutings more than a half to two-thirds of chamber height and reach tops of chamber in polar 
Table 13. Measurements of Chusenella sp. B (in mm. unless otherwise stated)

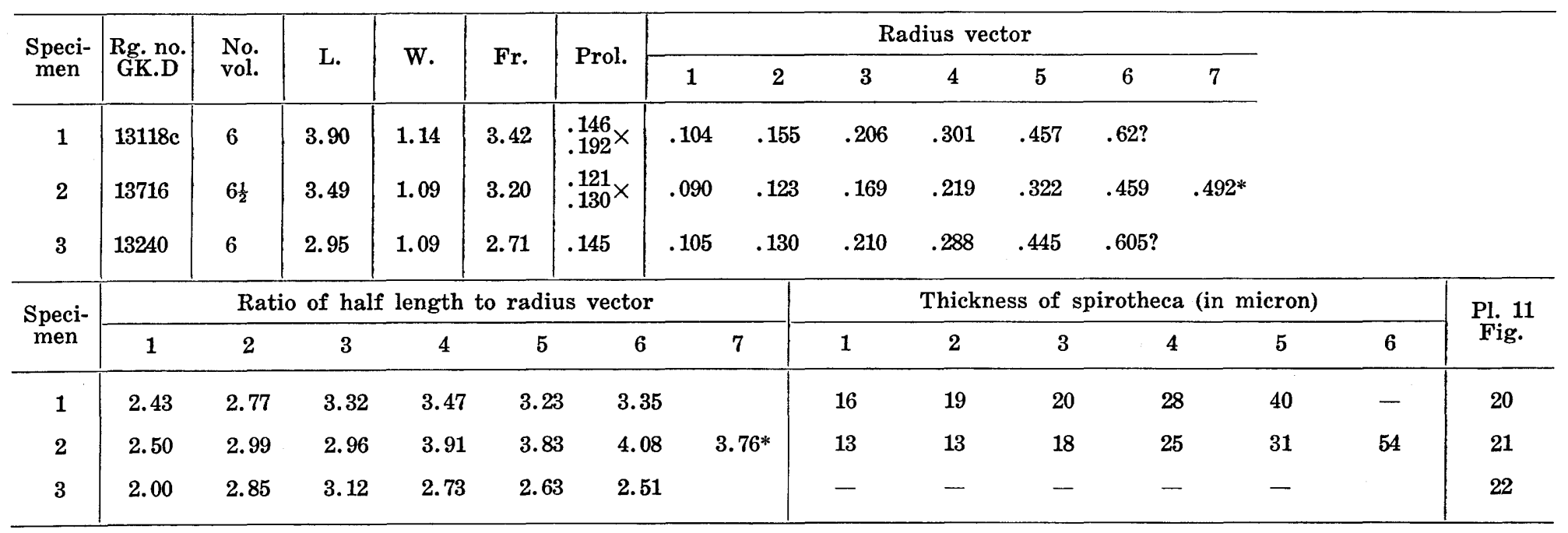

* measured a half volution earlier than others in the same column. 
areas. Incipient chomata present in inner few volutions. Tunnel low and wide, with irregular path. Tunnel angles of the first to fourth volutions in one specimen $23^{\circ}, 24^{\circ}, 22^{\circ}$, and $22^{\circ}$, respectively. Heavy secondary deposits fill axial region of chamber almost throughout growth.

Remarks:-The present form is similar to Chusenella tieni described by CHEN (1956) as a species of Schwagerina from the Chinghsichung Limestone of Hunan, South China. Later, SHENG (1963) referred it to the genus Chusenella because it has tightly coiled inner volutions and unfluted septa in the juvenarium.

The Khao Phlong Phrab specimens, though not sufficient in number, also have tightly coiled inner volutions where septa are almost plane. However, since septa seem to fold not so intensely even in outer volutions, the present species has been placed in the genus Chusenella with a query. If it is a species of Chusenella, it is one of the smallest and most primitive representatives among the genus as well as C. tieni.

Occurrence:-Rare at Kpp-22, -23, and -39. The upper part of the $B_{3}$ to the basal part of the $B_{5}$ zone.

Family Verbeekinidae STAFF and WEDEKIND, 1910

Subfamily Misellininae MrKLUKHo-MAKLAY, 1958

Genus Misellina SchencK and Thompson, 1940

Subgenus Misellina SchencK and ThOMPSON, 1940

Misellina (Misellina) otai SaKaguchI and Sugano

Pl. 12, Figs. 1-2

1967. Misellina otai Sakaguchi and Sugano. Jour. Osaka Gakugei Univ., B, no. 15, p. 145-147, p. 11, figs. 1-12.

Material:-Axial (slightly tangential) section, GK.D 13191 from Kpp-11.

Description:-Misellina otai in the Khao Phlong Phrab collection is represented by only a single axial section on which the following description is based.

Shell small and nearly spherical, with straight axis of coiling, exclusively convex lateral slopes, and broadly rounded but slightly umbilicated polar regions. The axial section is $1.41 \mathrm{~mm}$ in length and $1.36 \mathrm{~mm}$ in width, with a form ratio of 1.04. Shell retains nearly the same axial profile throughout growth. Ratios of half length to radius vector of the first to sixth volutions $0.97,1.00,0.86,1.00,1.06$, and 1.05 , respectively.

Although the section was cut not exactly through the center of shell, proloculus seems to be almost spherical with a diameter of about 100 microns or so. Shell coils tightly in inner three volutions and expands gradually and uniformly in outer three volutions. Radius vectors of the first to sixth volutions $115,175,265$, 385,530 , and 685 microns, respectively. Chamber is almost the same in height throughout volution.

Spirotheca rather thick for the size of shell, consisting of a tectum and a keriotheca, although minute alveolar structure is hardly observable in inner two volutions. Thickness of spirotheca $12,17,19,25$, and 22 microns, respectively in the second to sixth volutions.

Parachomata not present in the first volution, very primitve and rudimentary in development in the second volution. In outer volutions broad and low para- 
chomata well developed, being one-third to a half as high as chamber. As no sagittal section has been available characters of septa unknown.

Remarks:-The present specimen well agrees with the Akiyoshi specimens in all the important diagnostic characteristics. Since the Khao Phlong Phrab specimen is not well oriented, it is not known whether it has a discoidal juvenarium volutions which are clearly shown in the Akiyoshi specimens.

As SAKAgUCHI and SUgANo mentioned, Misellina otai is most primitive representative of the genus, and its stratigraphic occurrence is lower than that of $M$. claudiae. In the Akiyoshi Limestone Group $M$. otai occurs in the upper part of the Pseudofusulina valgaris zone and possibly the lower part of the P. ambigua zone.

Occurrence:-Very rare at Kpp- 11 . The lowest part of the $B_{1}$ zone.

\section{Misellina (Misellina) cfr. termieri (DEPRAT)}

Pl. 12, Figs. 5-10

1915. Doliolina termieri Deprat. Mém. Serv. Géol. l'Indochine, tome 4, fasc. 1, p. 17-18, pl. 3, figs. 15-20.

1962. Misellina cf. termieri SUyARI. Jour. Gakugei, Tokushima Univ., Nat. Sci., vol. 12, p. 33, pl.10, figs. 6-8.

1964. Misellina termieri Leven. Paleont. Jour. Acad. Sci. USSR, 1964, 4, pl.1, figs. 7-9.

1967. Misellina termieri Leven. Geol. Inst. Acad. Sci. USSR, Transact. 167, p. 183, pl. 29, figs. 10-11.

Lectotype:-Since DEPRAT's fig. 15 of plate III is only illustrated axial section in the original description, it is here designated as the lectotype of Misellina termieri.

Material:-Axial sections, GK.D 13706a from Kpp-5, GK.D 13171 from Kpp-9, GK.D 13177 from Kpp-10, sagittal sections, GK.D 13155b from Kpp-7, GK.D 13187 from Kpp-9, and GK.D 13179 from Kpp-10.

Description:-Shell small and elliptical in axial profile, with straight axis of coiling, exclusively convex lateral slopes and broadly rounded poles. Mature shell of 7 to $7 \frac{1}{2}$ volutions 1.63 to $2.00 \mathrm{~mm}$ in length and 1.28 to $1.91 \mathrm{~mm}$ in width, with form ratio of 1.27. The first two volutions nearly spherical to subspherical. Axis extends slowly during growth. Ratios of half length to radius vector of the first to seventh volutions in two specimens $1.07-1.16,1.00-1.22,1.15-1.25,1.31-1.33$, 1.29-1.33, 1.23-1.30, and 1.27-1.33, respectively.

Proloculus small and spherical to subspherical, with the longest diameter of 208 microns and the shortest one of 128 microns. Shell expands very slowly in the first volution, and from the second volution expansion becomes gradual and slightly rapid. Radius vectors of the first to seventh volutions in four specimens average 151,216, 294, 385, 499, 565, and 696 microns, respectively. Chambers nearly the same in height from pole to pole.

Spirotheca rather thick for size of shell, consisting of a tectum and lower thick layer. Faint alveolar structure observed in the lower layer of outer three to four volutions. Thickness of spirotheca in the first to seventh volutions in four specimens averages $13,15,15,16,17,20$, and 20 microns, respectively.

Septa essentially the same in structure as spirotheca, being composed of downward extension of tectum coated by lower layer on both sides. Septal counts of 
Table 14. Measurements of Misellina cfr. termieri (DEPRAT) (in mm. unless otherwise stated)

\begin{tabular}{|c|c|c|c|c|c|c|c|c|c|c|c|c|c|c|c|c|}
\hline \multirow{2}{*}{$\begin{array}{l}\text { Speci- } \\
\text { men }\end{array}$} & \multirow{2}{*}{$\begin{array}{c}\text { Rg. no. } \\
\text { GK.D }\end{array}$} & \multirow{2}{*}{$\begin{array}{l}\text { No. } \\
\text { vol. }\end{array}$} & \multirow{2}{*}{ L. } & \multirow{2}{*}{ W. } & \multirow{2}{*}{ Fr. } & \multirow{2}{*}{ Prol. } & \multicolumn{8}{|c|}{ Radius vector } & & \multirow{8}{*}{$\begin{array}{l}\text { Pl. } 12 \\
\text { Fig. }\end{array}$} \\
\hline & & & & & & & 1 & 2 & 3 & 4 & 5 & 6 & 7 & 8 & & \\
\hline 1 & 13177 & 7 & 2.00 & 1.58 & 1.27 & $.136 \times$ & .126 & .185 & .256 & .336 & .471 & .615 & .800 & \multirow{4}{*}{$.672 *$} & & \\
\hline 2 & $13706 a$ & $7 \frac{1}{2}$ & 1.63 & 1.28 & 1.27 & $.128 \times$ & .112 & .160 & .208 & .280 & .360 & .480 & .592 & & & \\
\hline 3 & 13179 & $5 \frac{1}{2}$ & - & 1.91 & - & .160 & .216 & .318 & .430 & .560 & .701 & \multicolumn{2}{|l|}{$.800^{*}$} & & & \\
\hline 4 & $13155 \mathrm{~b}$ & 6 & - & 1.20 & - & $.168 \times$ & .150 & .200 & .281 & .364 & .466 & \multicolumn{2}{|l|}{.601} & & & \\
\hline \multirow{2}{*}{$\begin{array}{c}\text { Speci- } \\
\text { men }\end{array}$} & \multicolumn{8}{|c|}{ Ratio of half length to radius vector } & \multicolumn{7}{|c|}{ Thickness of spirotheca (in micron) } & \\
\hline & 1 & 2 & 3 & 4 & 5 & 6 & 7 & 8 & 1 & 2 & 3 & 4 & 5 & 6 & 7 & \\
\hline 1 & 1.16 & 1.22 & 1.25 & 1.33 & 1.33 & 1.30 & 1.33 & & 13 & 15 & 14 & 14 & 15 & 25 & 20 & 5 \\
\hline 2 & 1.07 & 1.66 & 1.15 & 1.31 & 1.29 & 1.23 & 1.27 & $1.31^{*}$ & 9 & 14 & 15 & 15 & 16 & 18 & 20 & 7 \\
\hline 3 & & & & & & & & & 18 & 20 & 20 & 20 & 19 & & & 8 \\
\hline 4 & & & & & & & & & - & 10 & 11 & 14 & 14 & 16 & & 10 \\
\hline \multirow{2}{*}{$\begin{array}{l}\text { Speci- } \\
\text { men }\end{array}$} & \multicolumn{7}{|c|}{ Tunnel angle/Septal count } & & & & & & & & & \\
\hline & 1 & 2 & 3 & 4 & 5 & 6 & 7 & & & & & & & & & \\
\hline 1 & $16^{\circ}$ & $16^{\circ}$ & $16^{\circ}$ & $17^{\circ}$ & $21^{\circ}$ & $21^{\circ}$ & $26^{\circ}$ & & & & & & & & & \\
\hline 3 & 9 & 14 & 17 & 20 & $23+$ & & & & & & & & & & & \\
\hline 4 & $6 ?$ & 13 & 15 & 20 & 21 & & & & & & & & & & & \\
\hline
\end{tabular}

* measured a half volution earlier than others in the same column. 
the first to fifth volutions in two specimens $6 ?-9,13-14,15-17,20$, and $21-23$, respectively.

Parachomata present in all but the first volution. In the second and third volutions, however, they are still incipient in development. In outer volutions they are high and narrow and a half to two-thirds as high as chambers.

Remarks:-Misellina termieri was described by DEPRAT (1915) from Cammon together with $M$. minor (DEPRAT), Pseudofusulina subcylindica (DEPRAT) and $P$. ambigua (DEPRAT), and is moderate in the phylogenetical stage of development of Misellina.

Although the Khao Phlong Phrab specimens are not sufficient in number, they are considerably well agreeable with the DEPRAT's type in many shell characteristics, except for that the former has a larger proloculus than the latter, and that the expansion of volution is a little faster in the former.

SUYARI (1962) described $M$. cf. termieri from the upper part of the Kameiwa Formation in Shikoku, Japan. Since his specimens are, however, not well oriented and seem not in good state of preservation, detailed comparison with the present specimens is not advisable.

LEVEN (1967) described the present species from the Misellina zone of Southwest Pamir. Judging from his microphotographs, the Pamir specimens are considerably smaller in size and more spherical in shape than the DEPRAT's type.

Occurrence:-Common at Kpp-10, -9, -5, and -7. The upper part of the $B_{1}$ and the lower part of the $\mathrm{B}_{2}$ zone.

\section{Misellina (Misellina) subelliptica (DEPRAT) P1. 12, Figs. 3-4}

1915. Doliolina subelliptica Deprat. Mém. Serv. Géol. l'Indochine, tome 4, fasc. 1, p. 19-20, pl. 3, figs. 5-6.

1963. Misellina subelliptica Ishizaki. Transact. Proc. Palaeont. Soc. Japan, N.S., no. 50, p. 61-62, pl. 9, figs. 8-18.

Material:-Axial sections, GK.D 13107a and 13107b from Kpp-24.

Descriptive remarks:-ISHIZAKI (1963) described Misellina subelliptica in detail from the Shingai Formation of South Shikoku, although most, if not all, of his specimens are considerably deformed. He regarded the present species as a transitional form in phylogenetic lineage between Misellina and Brevaxina based on the fact that $M$. subelliptica from the Shingai Formation has a rather strongly laterally depressed shell form and parachomata which are much narrower and higher in the medin part with quite narrowly pointed tips.

ISHIZAKI further mentioned that the specimens described by SUYARI (1962) as M. termieri from Tosayama, South Shikoku may be identical with $M$. subelliptica from the Shingai Formation. However, it is noted that SUYARI regarded $M$. subelliptica as a synonym of $M$. termieri by the reason that no distinction present between these two species.

It is true that these two species are closely allied with each other in many shell characteristics, especially in general shape and dimension of shell, but in detailed comprison, there are some difference between them as DEPRAT mentioned, namely, $M$. subelliptica has a faster expansion of volutions, a thinner spirotheca, more numerous septa for corresponding volutions, and slightly less massive para- 
Table 15. Measurements of Misellina subelliptica (DEPRAT) (in mm. unless otherwise stated)

\begin{tabular}{|c|c|c|c|c|c|c|c|c|c|c|c|c|c|c|c|c|c|}
\hline \multirow{2}{*}{$\begin{array}{c}\text { Speci- } \\
\text { men }\end{array}$} & \multirow{2}{*}{$\begin{array}{l}\text { Rg.no. } \\
\text { GK.D }\end{array}$} & \multirow{2}{*}{$\begin{array}{l}\text { No. } \\
\text { vol. }\end{array}$} & \multirow{2}{*}{ L. } & \multirow{2}{*}{ W. } & \multirow{2}{*}{ Fr. } & \multirow{2}{*}{ Prol. } & \multicolumn{9}{|c|}{ Radius vector } & & \\
\hline & & & & & & & 1 & 2 & 3 & 4 & & 5 & 6 & 7 & 8 & & \\
\hline 1 & $13107 \mathrm{a}$ & 7 & 1.60 & 1.28 & 1.25 & $\begin{array}{l}.096 \\
.155\end{array}$ & .112 & .165 & .242 & $.3 x$ & & .412 & .520 & .672 & & & \\
\hline 2 & $13107 \mathrm{~b}$ & 8 & 1.73 & 1.49 & 1.16 & - & - & .145 & .192 & .2 & & .355 & .440 & .555 & .655 & & \\
\hline \multirow{2}{*}{$\begin{array}{c}\text { Speci- } \\
\text { men }\end{array}$} & \multicolumn{8}{|c|}{ Ratio of half length to radius vector } & \multicolumn{8}{|c|}{ Thickness of spirotheca (in micron) } & \multirow{2}{*}{$\begin{array}{l}\text { Pl. } 12 \\
\text { Fig. }\end{array}$} \\
\hline & 1 & 2 & 3 & 4 & 5 & 6 & 7 & 8 & 1 & 2 & 3 & 4 & 5 & 6 & 7 & 8 & \\
\hline 1 & 1.00 & 1.06 & 1.06 & 1.16 & 1.29 & 1.32 & 1.29 & & 10 & 10 & 11 & 13 & 13 & 15 & 15 & & 3 \\
\hline 2 & - & 1.00 & 1.25 & 1.45 & 1.41 & 1.45 & 1.38 & 1.30 & - & 10 & 12 & 12 & 14 & 14 & 14 & 16 & 4 \\
\hline
\end{tabular}


chomata than those of $M$. termieri. Thus, they may probably be regarded at least as two subspecies in one species. More detailed paleontologic study on sufficient materials is necessary before the final decision is given. From evolutionary points of view, $M$. subelliptica is considered to be slightly advanced than $M$. termieri.

The Khao Phlong Phrab specimens well agree with the DEPRAT's type in important shell characteristics except that the former has a little smaller size of shell and a considerably larger proloculus than the latter. Since the material at hand is very insufficient, the mensural data of the Khao Phlong Phrab specimens are only given here, without giving a detailed specific description.

Occurrence:-Only known at Kpp-24. The upper part of the $B_{3}$ zone.

\section{Misellina (Misellina) confragaspira LEVEN}

Pl. 12, Figs. 11-46

1967. Misellina confragaspira LEven. Acad. Sci. USSR, Geol. Inst. Transact. vol. 167, p. 184-185, pl. 31, figs. 2-4.

Lectotype:-Fig. 3 of plate 31 of Leven's specimens is designed as the lectotype of the species.

Material:-Axial sections, GK.D 13701, 14006, 10412, and 14098 from Kpp-5, GK.D 13155, 13156a, 13156b, 13162, 13166, and 14099 from Kpp-7, GK.D 13902 and 13904 from Kpp-19, and GK.D 13024, 13095, 13101c, 13102, 14103, 13110a, 13110e, and 13112 from Kpp-24; sagittal sections, GK.D 13700 and 13702 from Kpp-5, GK.D 13156c, 13158, 13165a, 13165b, and 13167 from Kpp-7, GK.D 13199 from Kpp-18, GK.D 13900 from Kpp-19, and GK.D 13101b, 13111, and 13113 from Kpp-24. Many other sectioned specimens are referred to this species.

Description:-Shell small and typical fusiform with straight axis of coiling, gently convex lateral slopes, and rounded poles. Mature shell of 7 to $8 \frac{1}{2}$ volutions attains a length of 2.40 to $2.68 \mathrm{~mm}$ and a width of 1.26 to $1.62 \mathrm{~mm}$, giving a form ratio of 1.65 to 1.98 . The first one to two volutions spherical to subspherical, the succeeding two volutions short fusiform, and outer three to four volutions take typical fusiform. Ratios of half length to radius vector of the first to eighth volutions in six specimens $1.12,1.34,1.46,1.59,1.67,1.69,1.73$, and 1.83 , respectively in average.

Proloculus small and spherical to subspherical with structureless thin wall of about 12 microns. The longest outside diameter measures 156 to 224 microns and the shortest one 105 to 175 microns. Shell expands slowly in inner three volutions, and less slowly and uniformly in outer volutions. Radius vectors of the first to seventh volutions in nine specimens average 126, 177, 241, 322, 421, 545, and 628 microns, respectively. Chamber nearly the same in height in central half of shell, and becomes gradually high towards poles.

Spirotheca thin and consists of a tectum and a keriotheca. Fine alveolar structure of keriotheca is not observable in inner few volutions. Rugosity of spirotheca is hardly observed. Thickness of spirotheca of the first to seventh volutions in seven specimens is $11,12,14,15,17,18$, and 19 microns, respectively.

Septa essentially the same in structure as spirotheca. Septal counts of the first to sixth volutions in three specimens average $7,12,14,15,17$, and 18 , respectively. Although neither axial nor transverse septula present, it is noted that the lower surface of spirotheca in outer volutions partly show slight downward swel- 
Table 16. Measurements of Misellina confragaspira LEVEN (in mm. unless otherwise stated)

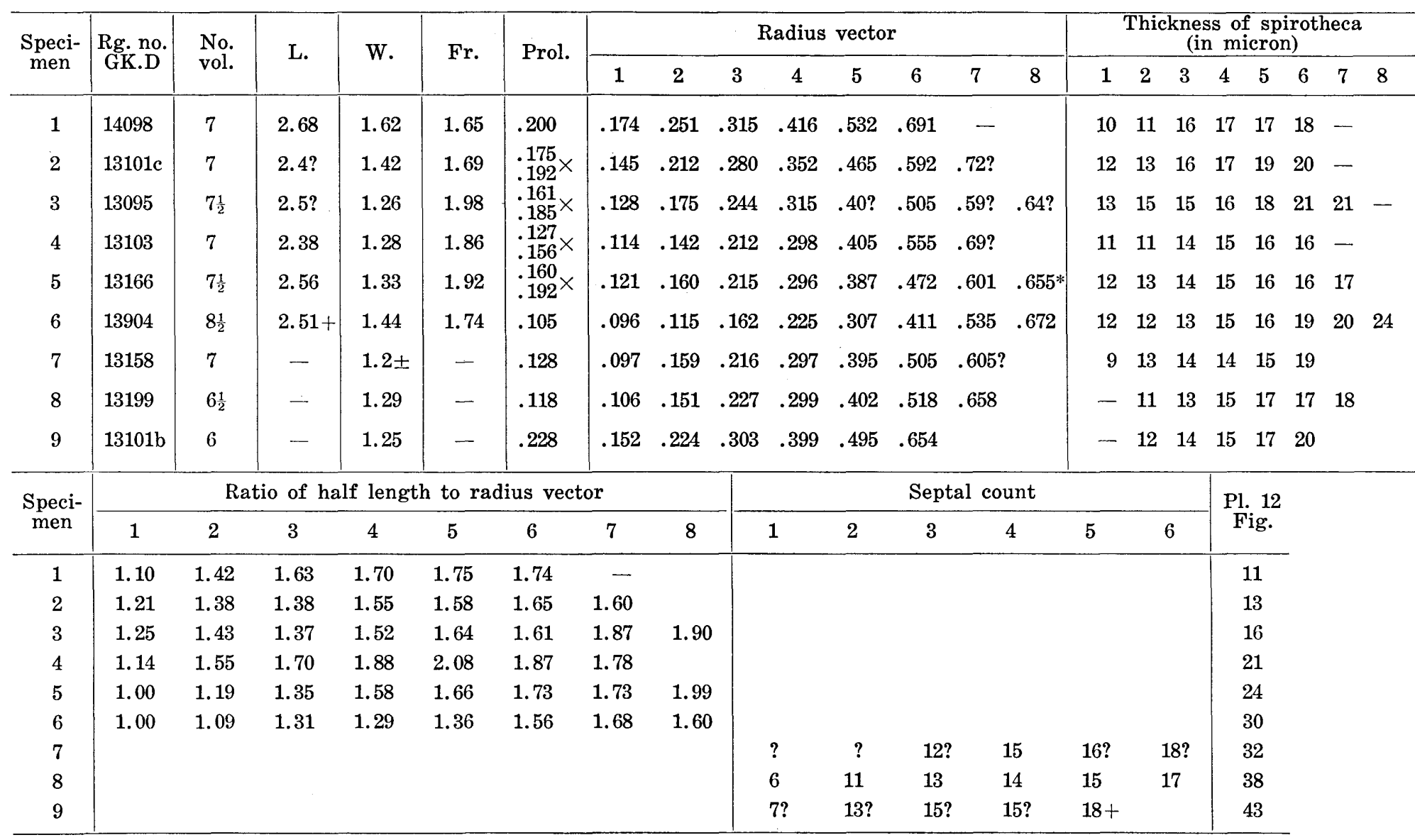

* measured a half volution earlier than others in the same column. 
ling just above parachomata, which suggests very incipient stage in forming primary transverse septula.

Parachomata well developed throughout growth, being high and narrow. They are usually about a half to two-thirds as high as chambers, but in some specimens (e.g. in GK.D 13904) they are almost the same in height as chamber and their tips almost reach lower surface of spirotheca in outer volutions.

Remarks:-LEVEN (1967) established Misellina confragaspira based on the four axial sections obtained from the Kurteke Formation of Southeast Pamir. It is noted that the spirotheca of Pamir specimens show some rugosity, by which the specific name was given, but it is not so remarkable, being observed in a limited part of outer volutions in his specimens 2 and 3.

In the Khao Phlong Phrab specimens rugosity of spirotheca is hardly recognizable, but spirotheca of outer volutions partly shows slight unevenness where the lower surface of keriotheca extends downward, suggesting very incipient stage of primary transverse septula.

Considering the specific characteristics, the present species seems to be a considerably advanced representative of the genus Misellina.

Occurrence:-Abundant at $\mathrm{Kpp}-5,-7$, and -24 ; common at $\mathrm{Kpp}-19$; and rare at Kpp-6 and -18. The lower part of the $\mathrm{B}_{2}$ zone.

\section{Misellina (Misellina) claudiae (DEPRAT) Pl. 13, Figs. 1-2}

1912. Doliolina claudiae Deprat. Mém. Serv. Géol. l'Indochine, tome 1, fasc. 3, p. 44-45, pl. 4, figs. 5-9.

1913. Doliolina claudiae Deprat. ibid. tome 2, fasc. 1, p. 50.

1925. Doliolina claudiae Ozawa. Jour. Coll. Sci. Imp. Univ. Tokyo, vol. 45, no. 4, p. 18, pl. 2, figs. 1, 2.

1934. Doliolina claudiae Chen. Palaeontologia Sinica, Ser. B, vol. 4, no. 2, p. 99100, pl. 16, figs. 13-20.

1936. Doliolina claudiae Huzimoto. Sci. Rep. Tokyo Bunrika Daigaku, Sec. C, vol. 1, no. 2, p. 104-105, pl. 21, figs. 4-9.

1957. Misellina cf. claudiae KobayASHI. Sci. Rep. Tokyo Kyoiku Daigaku, Sec. C, vol. 5, no. 48, p. 296-297, pl. 1, fig. 19.

1958. Misellina claudiae SAKAgAMI. Jour. Hokkaido Gakugei Univ., vol. 9, no. 2, p. 89-90, pl. 4, figs. $1,2$.

1958. Misellina claudiae Toriyama. Mem. Fac. Sci. Kyushu Univ., Ser. D, Geol., vol. 7, p. 208-211, pl. 38, figs. 1-17.

1960. Misellina claudiae KANuma. Bull. Tokyo Gakugei Univ., no.11, p.64-65, pl. 11, figs. 2-9.

1961. Misellina aff. claudiae Nogami. Mem. Coll. Sci. Univ. Kyoto, Ser. B, vol. 28 , no. 2, p. 169-171, pl. 7, figs. 7-9.

1963. Misellina claudiae Kanmera. Mem. Fac. Sci. Kyushu Univ., Ser. D, Geol., vol. 14, no. 2, p. 110-112, pl.14, figs. 7-14.

1963. Misellina claudiae Sheng. Palaeont. Sinica, N.S., B, no. 10, p. 222-223, pl. 28, fig. 15; pl. 30, figs. 12-19.

1967. Misellina claudiae Leven. Acad. Sci. USSR, Geol. Inst. Transact., vol.167, p. 181-182, pl. 30, figs. 7-8.

Lectotype:-DEPRAT's fig. 5 of pl. 4 designated by TorIYAMA (1958).

Material:-Axial section, GK.D 13724 from Kpp-23; sagittal section, GK.D 13714 from Kpp-23. 
Table 17. Measurements of Misellina claudiae (DEPRAT) (in mm. unless otherwise stated)

\begin{tabular}{|c|c|c|c|c|c|c|c|c|c|c|c|c|c|c|c|c|c|c|c|c|}
\hline \multirow{2}{*}{$\begin{array}{c}\text { Speci- } \\
\text { men }\end{array}$} & \multirow{2}{*}{$\begin{array}{l}\text { Rg. no. } \\
\text { GK.D }\end{array}$} & \multirow{2}{*}{$\begin{array}{l}\text { No. } \\
\text { vol. }\end{array}$} & \multirow{2}{*}{ L. } & \multirow{2}{*}{\multicolumn{2}{|c|}{ w. }} & \multirow{2}{*}{ Fr. } & \multirow{2}{*}{ Prol. } & \multicolumn{11}{|c|}{ Radius vector } & \multirow{2}{*}{\multicolumn{2}{|c|}{$\begin{array}{l}\text { Pl. } 13 \\
\text { Fig. }\end{array}$}} \\
\hline & & & & & & & & 1 & 2 & 3 & 4 & 5 & 6 & & 7 & 8 & 9 & 10 & & \\
\hline 1 & 13724 & 10 & 2 . & & 2.00 & 1.23 & $.05 \pm$ & .055 & .081 & .126 & .185 & .254 & .34 & & .461 & .608 & .782 & .992 & & 1 \\
\hline 2 & 13714 & 8 & - & & 1.48 & - & .059 & .067 & .113 & .174 & .259 & .353 & .47 & & .615 & .777 & & & & 2 \\
\hline \multirow{2}{*}{$\begin{array}{l}\text { Speci- } \\
\text { men }\end{array}$} & \multicolumn{10}{|c|}{ Ratio of half length to radius vector } & \multicolumn{10}{|c|}{ Thickness of spirotheca (in micron) } \\
\hline & 1 & 2 & 3 & 4 & 5 & 6 & 7 & 8 & 9 & 10 & 1 & 2 & 3 & 4 & 5 & 6 & 7 & 8 & 9 & 10 \\
\hline 1 & 1.18 & 1.40 & 1.34 & 1.43 & 1.51 & 1.48 & 1.50 & 1.39 & 1.35 & 1.28 & 7 & 8 & 10 & 11 & 18 & 21 & 25 & 29 & 32 & 31 \\
\hline 2 & & & & & & & & & & & 10 & 11 & 14 & 16 & 17 & 16 & 17 & 20 & & \\
\hline \multirow{2}{*}{$\begin{array}{c}\text { Speci- } \\
\text { men }\end{array}$} & \multicolumn{11}{|c|}{ Septal count } & & & & & & & & & \\
\hline & 1 & 2 & 3 & & 4 & 5 & 6 & 7 & 8 & 9 & 10 & & & & & & & & & \\
\hline 2 & $7 ?$ & $11 ?$ & 1 & & 17 & 19 & 19 & 23 & - & - & - & & & & & & & & & \\
\hline
\end{tabular}


Descriptive remarks:-Since the present species has been reported by many previous workers with detailed descriptions from several localities of Japan, South China, and Pamir, no further description is necessary.

The Khao Phlong Phrab specimens, represented by each one of axial and sagittal section, well agree with the DEPRAT's type in essential diagnostic characteristics. The former has, however, more numerous number of volution and slower rate of expansion. As mentioned by Toriyama (1958), the present species shows a considerable variation in the proloculus size, rate of expansion, and development of parachomata, the difference between the Khao Phlong Phrab and Indochinese specimens is therefore regarded as variations within the species.

Occurrence:-Rare at Kpp-23. The upper part of the $\mathrm{B}_{3}$ zone.

\section{Misellina (Misellina) ovalis (DEPRAT) \\ Pl. 13, Figs. 3-9}

1915. Doliolina ovalis Deprat. Mém. Serv. Géol. l'Indochine, tome 4, fasc. 1, p. 15-16, pl. 3, figs. 1-4.

1962. Misellina ovalis Sheng. Acta Palaeont. Sinica, vol. 10, no. 4, p. 428-429, pl. 1, figs. 10-14.

1963. Misellina ovalis Sheng. Palaeont. Sinica, N.S., B, no. 10, p. 221-222, pl. 34, figs. 16-21.

1967. Misellina ovalis LeVEN, Acad. Sci. USSR, Geol. Inst. Transact., vol.167, p. 181, pl. 26, figs. 2, 3,6; pl. 33, fig. 2.

Lectotype:-The specimen illustrated as plate 3 , fig. 1 is only illustrated axial section in the original description of DEPRAT (1915). Therefore this specimen is automatically the type of the species.

Material:-Axial sections, GK.D 13201, 13204, and 13206 from Kpp-18, GK.D 13015 from Kpp-37 and GK.D 14069 from Kpp-39; sagittal section, Kpp-13200 from Kpp-18.

Description:-Shell small and oval in axial profile, with gently convex lateral slopes and rounded poles. Mature shell of 8 to 9 volutions 2.52 to $2.56 \mathrm{~mm}$ in length and 1.26 to $1.52 \mathrm{~mm}$ in width, giving a form ratio of 1.68 to 2.00 . The first volution subspherical, the second volution ellipsoidal, and thereafter shell assumes oval in axial profile. Ratios of half length to radius vector of the first to eighth volutions in one axial section (GK.D 13201, specimen-1) 1.69, 2.26, 2.54, 2.70, 2.48, $2.44,2.14$, and 2.03 , respectively. In another axial section probably of microspheric form (GK.D 14069) the first volution seems to coil at a large angles to outer volutions. In this specimen ratios of half length to radius vector of the first to ninth volutions $1.62,1.67,1.84,1.86,1.86,1.80,1.90,1.82$, and 1.70 , respectively.

Proloculus small and subspherical, with outside diameter of $128 \times 176$ microns in specimen-1 and $145 \times 208$ microns in sagittal section. In microspheric form outside diameter probably less than 70 microns. First one or two volutions coils somewhat tightly, and succeeding volutions expand more or less rapidly but almost uniformly. Radius vectors of the first to eighth volutions $104,135,185,255,334$, 432,545 , and 656 microns, respectively in specimen-1, and $121,156,204,265,336$, 440,568 , and 735 microns, respectively in sagittal section. Those of first to ninth volutions in microspheric form $65,113,153,215,307,408,490,626$, and 752 microns, respectively.

Spirotheca relatively thin, consisting of a tectum and a fine alveolar keriotheca. 
Alveolar structure is not clear in inner volutions. Thickness of spirotheca of the first to seventh volutions in specimen-1 12,12,13,14,14, 19, and 15 microns, respectively. Those of the second to ninth volutions in microspheric form $11,12,15$, $17,19,20,21$, and 22 microns, respectively.

Parachomata considerably well developed in all but the first two volutions where they are not present or very rudimentary if present. In outer volutions parachomata low and broad, being one-third to a half as high as chambers. Septa thin and relatively tightly spaced, with septal counts of 6 ?, 12?,15?, 15?, 19, 19, and 21 in the first to seventh volutions.

Remarks:-In the original description of DEPRAT (1915), the shell of Misellina ovalis is $2.7 \mathrm{~mm}$ in length and $1.4 \mathrm{~mm}$ in width. However, if the magnification shown in plate III $(\times 15)$ is correct, the lectotype specimen (fig. 1 of plate III) is $3.68 \mathrm{~mm}$ in length and $2.16 \mathrm{~mm}$ in width. The same confliction between the actual dimension measured from his illustration and the dimension given by DEPRAT in the text is found in M. termieri.

The Khao Phlong Phrab specimens, though not sufficient in number, almost identical in essential diagnostic characteristic with DEPRAT's type if the dimension in the original text is correct.

SHENG (1962, 1963) described the present species from the Sanmianching Formation of northern Hopei and the lower part of the Chihsia Limestone at Pingding, Kwangsi and Zisongzheng, Kueichow. In the latter he distinguished microspheric and megalospheric forms although difference of proloculus diameter is not so remarkable, being about twice in the latter. The microspheric and megalospheric forms of Khao Phlong Phrab specimens nearly identical to those from the Chihsia Limestone.

LEVEN (1967) also described $M$. ovalis from southern Pamir, but his specimens are a little larger than those of Khao Phlong Phrab and South China.

Misellina ovalis is similar to $M$. confragaspira LEVEN, but the latter is distinguished from the former in having a little smaller shell, essentially planispiral coiling, and an incipient sign for forming primary transverse septula.

Occurrence:-Rare at Kpp-18, -24, -37, and -39. The $B_{2}$ to $B_{4}$ zones.

Subgenus Brevaxina Schenck and THOMPsoN, 1940

Misellina (Brevaxina) compressa (DEPRAT)

Pl. 13, Figs. 14-15

1915. Doliolina compressa Deprat. Mém. Serv. Géol. l'Indochine, tome 4, fasc. 1, p. 14-15, pl. 3, figs. 10-14.

Lectotype:-DEPRAT's fig. 10 of pl. 3.

Material:-Axial section, GK.D 13125 and 14190 from Kpp-39.

Description:- Shell inflated discoidal, with short axis of coiling and depressed polar ends. Shell of 11 volutions attains a length of $1.87 \mathrm{~mm}$ and a width of 3.00 $\mathrm{mm}$, giving a form ratio of 0.62 . The first volution endothyroid with depressed umbilical portions. The succeeding three volutions lenticular, and from the fifth volution the pole begins to be depressed again, though umbilication is not so distinct. Ratios of half length to radius vector of the first to eleventh volutions 0.35 , $0.51,0.51,0.53,0.60,0.59,0.61,0.63,0.64,0.63$, and 0.61 , respectively.

Proloculus minute and spherical with outside diameter of about 45 microns. 
Expansion of shell very slow in inner four volutions, and then becomes gradually rapid outwards. Radius vectors of the first to eleventh volutions 105, 146, 208, $272,375,515,680,865,1055,1328$, and 1520 microns, respectively.

Spirotheca very thin in inner three volutions and composed apparently of a single layer, but in outer volutions it becomes thicker, consisting of a tectum and a finely alveolar keriotheca. Thickness of spirotheca of the first to eleventh volutions $8,8,9,12,15,18,19,20,23,25$, and 20 (?) microns, respectively.

Parachomata well developed throughout length of shell, except in inner three volutions. They are narrow and high, being about a half to two-thirds as high as chamber.

Remarks:-The above description is based on a single axial section (GK.D 14190). This specimen is nearly identical with the DEPRAT's type from Cammon, Indochina in essential diagnostic characteristics. Both are almost equal in size of shell, but the DEPRAT's type specimen is fewer in number of volution than the Khao Phlong Phrab specimen, namely, the former is faster in the expansion of shell than the latter. Another difference is that parachomata occur in all but the first volution in the former, whereas they are not present in inner three volutions of the latter.

It is noted that both in Cammon and Khao Phlong Phrab the present species occurs along with Misellina ovalis (DEPRAT).

Occurrence:-Very rare at Kpp-39. The lowest part of the $\mathrm{B}_{5}$ zone.

Subfamily Verbeekininae STAFF and WEDEKIND, 1910

Genus Verbeekina STAFF, 1909

Subgenus Armenia MiklukHo-MAKLAY, 1955

Verbeekina (Armenia) saraburiensis TORIYAMA and KANMERA, n.sp. Pl. 13, Figs. 16-23

Material:-Holotype, GK.D 13175 from Kpp-9: Paratypes, axial sections, GK.D 13169 from Kpp-9 and GK.D 13176, 13178, 13180, and 13184 from Kpp-10; tangential section, GK.D 13180 from Kpp-10.

Description:-Shell subspherical and small for the genus, with straight axis of coiling and broadly rounded poles. The holotype specimen of six and a half volutions attains a length of $2.08 \mathrm{~mm}$ and a width of $1.38 \mathrm{~mm}$, with a form ratio of 1.38. Shell exclusively planispiral. The first volution spherical to subspherical, and from the second volution to maturity axial profile is nearly the same. Ratios of half length to radius vector in the first to sixth volutions in six specimens average $1.27,1.44,1.48,1.43,1.43$, and 1.34 , respectively.

Proloculus large for the size of shell, and spherical to subspherical, with outside diameter of 175 to $218 \times 377$ microns, and thin structureless proloculus wall of less than 10 microns thickness. Shell expands relatively slowly in inner two to three volutions and considerably rapidly in outer volutions. Average radius vectors of the first to sixth volutions in six specimens are $172,244,341,471,613$, and 800 microns, respectively. Chamber is essentially the same in height from pole to pole.

Spirotheca thin and consists of a dense tectum and a keriotheca, in the latter of which very fine alveoli are observable throughout the growth of shell. Thickness of spirotheca of the first to sixth volutions in six specimens average 14,16 , $17,19,21$, and 22 microns, respectively. 
Table 18. Measurements of Verbeekina (Armenia) saraburiensis ToRIYAma and KanMERA, n. sp.

(in mm. unless otherwie stated)

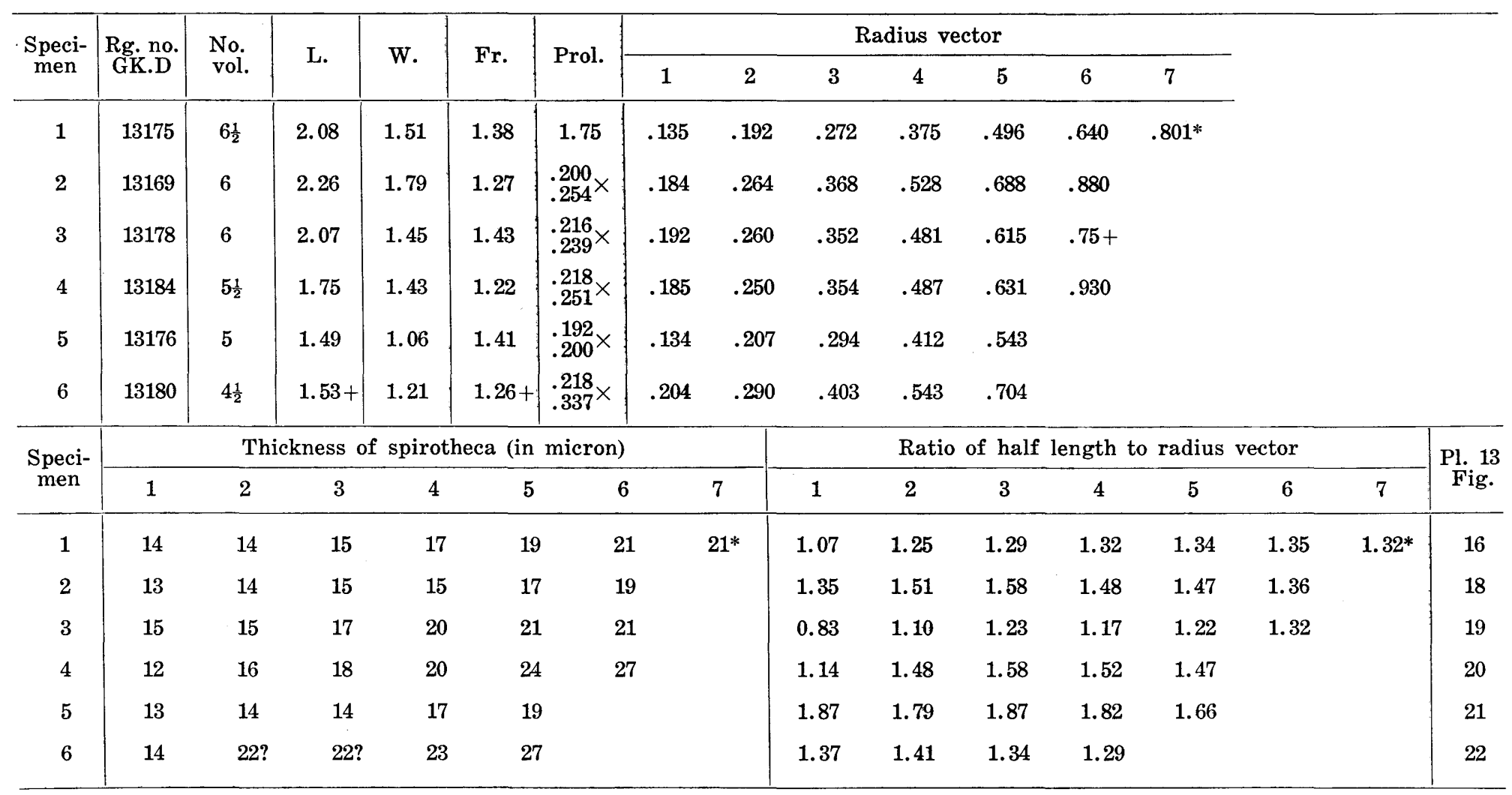

* measured a half volution earlier than others in the same column. 
Parachomata well developed throughout the growth. In inner volutions they are widely spaced, being low and wide with about a half as high as chamber. In outer volutions they are semicircular or triangular in cross section, but uneven in height, having one-fourth to more than a half of the height of chamber. About 28 and 23 parachomata are present in the last and penultimate volutions of the holotype specimen.

Remarks:-Verbeekina (Armenia) saraburiensis n. sp. is one of the most primitive representatives of the genus. The small size of shell, small number of volution, relatively thick spirotheca, and well developed parachomata throughout the growth are suggestive of that the present species is in earlier stage of a phylogenetic lineage of Misellina-Verbeekina (Armenia)_Verbeekina (Verbeekina). It is assumed that the present species is intermediate in shell characters between Misellina and Verbeekina (Armenia). The present species is not comparable with any species previously described.

Occurrence:-Rare at Kpp-9 and -10. Only known in the $\mathrm{B}_{1}$ zone.

\section{Verbeekina (Armenia) karinae MIKLUKHo-MAKLAY} Pl. 13, Figs. 24-27

1955. Armenia karinae MikLukho-Maklay. Dokl. Akad. Nauk, USSR, vol. 5, no. 3 , p. 576, text-fig. 1 e.

1964. Armenia karinae Leven. Izd. Acad. Nauk, USSR, Paleont. Jour., no.4, pl. 1, fig. 3.

Material:-Axial sections, GK.D 13901 from Kpp-19 and GK.D 13326 (more or less tangential) from Kpp-22 ; sagittal (slightly excentric) section, GK.D 13236 from Kpp-22.

Description:-Shell small to moderate in size, subspherical in form, with broadly rounded periphery and exclusively convex lateral slopes. Mature shell of ten volutions is $3.2(?) \mathrm{mm}$ in length and 2.52 (?) $\mathrm{mm}$ in width, with a form ratio of 1.27. The first volution discoidal with short axis of coiling. Beyond the second or third volution shell assumes a subspherical form. Ratios of half length to radius vector in the first to eighth volutions in one axial section (GK.D 13901) are 0.91, $0.89,1.09,1.26,1.17,1.22,1.36$, and 1.26 , respectively. Those of the other (GK.D 13326) in the second to tenth volutions are 1.52, 1.55, 1.50, 1.45, 1.49, 1.39, 1.33, and 1.31 , respectively.

Proloculus small and spherical, with an outside diameter of about 45 microns. Shell expands slowly in inner two to three volutions, and relatively rapidly and uniformly in outer volutions. Radius vectors of the first to tenth volutions in three specimens average $53,99,162,244,354,489,646,835,1055$, and 1295 microns, respectively. Chambers are almost the same in height from pole to pole.

Spirotheca thin and consists of seemingly a single layer in inner one or two volutions, but it is composed of a tectum and a very finely alveolar keriotheca. Thickness of spirotheca of the second to ninth volutions in three specimens average $10,11,15,19,20,23,26$, and 26 microns, respectively.

Septa thin and the same in structure as spirotheca. They are exclusively plane throughout the growth. No septula present. Parachomata not present in inner one to two volutions. In the succeeding three to four volutions parachomata appear although they are primitive in development, very low and broad with a 
height about one-fourth to one-third of chamber height. Parachomata well recognized in outer volutions where they are relatively widely spaced and semi-circular or obtuse triangular in axial profile. Their height does not exceed a half of chamber height. Septal counts of the fourth to ninth volutions in one specimen 11+, $11+, 12+, 13+$, and $14+$, respectively.

Remarks:-Armenia karinae was established by MIKLUKHo-MAKLAY (1955) based on very incomplete specimens. The Khao Phlong Phrab specimens, though insufficient in number too, are nearly identical with the type specimen came from Transcaucasia in the shell form and size, rate of expansion, development of parachomata. Only difference is that the Khao Phlong Phrab specimens are slightly less in number of volution and a little larger in form ratio.

The present species is considered to be more advanced than Verbeekina ( $A r$ menia) saraburiensis TORIYAMA and KANMERA, n. sp., but more primitive than $V$. (A.) prisca TORIYAMA and KanMera, n. sp. and $V$. (A.) sphaera (OzAWA). Therefore, a phylogenetical lineage, $V .(A$.) saraburiensis $-V$. (A.) karinae $-V$. (A.) prisca $-V$. (A.) sphaera is suggested.

Occurrence:-Rare at Kpp-19, -22, -23, and -25. The upper part of the $\mathrm{B}_{2}$ zone to the $\mathrm{B}_{4}$ zone.

Verbeekina (Armenia) prisca TORIYAMA and KANMERA, n. sp. Pl. 13, Figs. 28-39

Material:-Holotype, GK.D 13929 from Kpp-38. Paratypes, axial sections, GK.D 13034 and 13049 from Kpp-29, GK.D 13725 from Kpp-34, GK.D 13142 from Kpp-35, GK.D 13933b and 13953 from Kpp-38; tangential sections, GK.D 13254 from Kpp-26, GK.D 14054 from Kpp-36.

Description:- Shell subspherical to short melon-shape and small for the genus, with convex lateral slopes and rounded and slightly umbilicated poles. The holotype specimen of eight volutions attains a length of $2.26 \mathrm{~mm}$ and a width of $1.52 \mathrm{~mm}$, giving a form ratio of 1.49. The first volution coils probably askew to the outer volutions. Ratios of half length to radius vector in the first to eighth volutions in the holotype specimen are 1.68, 1.40,1.37, 1.36, 1.31, 1.36, 1.42, and 1.45 , respectively. However, those of one of the subspherical form (GK.D 13146) are $1.00,1.00,1.10,1.22,1.17,1.19,1.17$, and 1.14 , respectively.

Proloculus very small and spherical to subspherical, having outside diameter of 32 to 70 microns and proloculus wall has a thickness of less than 10 microns. Shell expands slowly in inner three volutions and considerably rapidly and almost uniformly in outer volutions. Radius vectors of the first to eighth volutions in seven specimens average $46,86,136,220,335,488,652$, and 832 microns, respectively. Chambers are nearly the same in height from pole to pole.

Spirotheca relatively thin and consists of a tectum and a keriotheca. Alveolar structure of the latter is clearly shown throughout the growth except for the first volution. Thicknesses of spirotheca of the first to eighth volutions in six specimens average $9,11,12,14,18,19,20$, and 19 microns, respectively.

Parachomata not present in the first one or two volutions. In the following two to three volutions they are very rudimentary in development, being low and widely spaced. Their height is less than one-fifth or one-fourth of chamber height. About 13 to 20 parachomata are observed in the fifth and sixth volutions of the holotype specimen. In the last volution parachomata become indistinct. 
Table 19. Measurements of Verbeekina (Armenia) prisca TORIYAMA and KANMERA, n. sp.

(in mm. unless otherwise stated)

\begin{tabular}{|c|c|c|c|c|c|c|c|c|c|c|c|c|c|c|c|c|c|}
\hline \multirow{2}{*}{$\begin{array}{c}\text { Speci- } \\
\text { men }\end{array}$} & \multirow{2}{*}{$\begin{array}{l}\text { Rg. no. } \\
\text { GK.D }\end{array}$} & \multirow{2}{*}{$\begin{array}{l}\text { No. } \\
\text { vol. }\end{array}$} & \multirow{2}{*}{ L. } & \multirow{2}{*}{$\mathrm{W}$. } & \multirow{2}{*}{ Fr. } & \multirow{2}{*}{ Prol. } & \multicolumn{10}{|c|}{ Radius vector } & \\
\hline & & & & & & & \multicolumn{5}{|c|}{4} & Hus vect & 6 & \multicolumn{2}{|r|}{8} & 9 & \\
\hline 1 & 13142 & 8 & $2.42+$ & 1.92 & 1.26 & $.037 ? \times$ & .045 & .095 & .146 & & & .344 & .479 & .632 & .848 & & \\
\hline 2 & 13929 & 8 & 2.26 & 1.52 & 1.49 & .032 & .041 & .082 & .128 & & & .305 & .448 & .592 & .785 & & \\
\hline 3 & 13049 & 8 & 2.27 & 1.39 & 1.63 & $.032 \times$ & .040 & .081 & .111 & & & .292 & .433 & .568 & .737 & & \\
\hline 4 & 13254 & 7 & $2.05 ?$ & 1.31 & 1.57 & - & $.049 ?$ & $.080 ?$ & .130 & & & .329 & .494 & .643 & & & \\
\hline 5 & $13933 b$ & 7 & 2.06 & 1.41 & 1.46 & - & .050 & .088 & .145 & & & .398 & .543 & .687 & & & \\
\hline 6 & 13725 & $8 \frac{1}{2}$ & 2.48 & 1.83 & 1.36 & .053 & .052 & .098 & .152 & & & .341 & .510 & .719 & .880 & & \\
\hline 7 & $13933 a$ & 9 & - & 2.11 & - & - & .045 & .080 & .140 & & & .336 & .511 & .720 & .911 & 1.085 & \\
\hline $\begin{array}{c}\text { Speci- } \\
\text { men }\end{array}$ & 1 & 2 & 3 & 4 & 5 & 6 & 7 & 8 & 1 & 2 & 3 & 4 & 5 & 6 & 7 & 8 & Fig. \\
\hline 1 & 1.78 & 1.53 & 1.71 & 1.50 & 1.60 & 1.53 & 1.52 & 1.38 & 9 & 9 & 14 & 15 & 19 & 19 & 20 & 20 & 28 \\
\hline 2 & 1.68 & 1.40 & 1.37 & 1.36 & 1.31 & 1.36 & 1.42 & 1.45 & 10 & 12 & 12 & 13 & 17 & 17 & 19 & 18 & 29 \\
\hline 3 & 2.00 & 1.40 & 1.75 & 1.57 & 1.72 & 1.70 & 1.69 & 1.63 & 8 & 8 & 10 & 13 & 15 & 17 & 20 & 20 & 31 \\
\hline 4 & 1.60 & 1.81 & 1.96 & 1.86 & 1.74 & 1.59 & 1.59 & & 11 & 14 & 14 & 16 & 19 & 19 & 21 & 20 & 33 \\
\hline 5 & 1.60 & 1.82 & 1.76 & 1.57 & 1.38 & 1.47 & 1.44 & & 10 & 10 & 12 & 13 & 16 & 19 & 20 & & 34 \\
\hline 6 & 1.22 & 1.63 & 1.68 & 1.67 & 1.74 & 1.54 & 1.38 & 1.40 & 8 & 11 & 12 & 13 & 20 & 21 & 20 & 19 & 38 \\
\hline
\end{tabular}


Remarks:-Verbeekina (Armenia) prisca n. sp. is one of the primitive representatives of verbeekinid. The small size of shell and small number of volution suggest that the present species is in an earlier stage of Verbeekina (Armenia)Verbeekina (Verbeekina) bioseries.

In the phylogenetic development of the $V .(A)-$.$V . ( V$.) bioseries, especially in the early stage, at least two lineages may be assumed; one is characterized by having larger proloculus and well developed parachomata and the other by having smaller proloculus and poorly developed parachomata. The former is well represented by $V$. (A.) saraburiensis $-V$. (A.) salgirica $-V$. (A.) karinae, and the latter by $V$. (A.) prisca $-V$. (A.) sphaera. Verbeekina (Verbeekina) s.s. is assumed to be a direct descendant from the latter.

Occurrence:-Rare at Kpp-26, -29, -30, -34, -36, and -38. The $\mathrm{B}_{4}$ zone.

\section{Verbeekina (Armenia) sphaera OzAWA}

P1. 14, Figs. 1-11

1927. Verbeekina verbeeki sphaera Ozawa (pro parte). Jour. Coll. Sci. Imp. Univ. Tokyo, vol. 45, art. 4, p. 153, pl. 38, figs. 14, 16-a (non fig. 14); pl. ]5, fig. 10b.

1956. Verbeekina verbeeki sphaera CHEN. Palaeontologia Sinica, N.S., B, no.6, p. 48, pl. 9, figs. 11, 12.

1960. Verbeekina sphaera Sugr. Trans. Proc. Palaeont. Soc. Japan, N.S., no. 39, p. 312-319, pl. 36, figs. 1-20.

1961. Verbeekina sphaera KanMera. Mem. Fac. Sci. Kyushu Univ., Ser. D, Geol., vol. 14, no. 2, p. 105-106, pl. 15, figs. 1-6.

Material:-Axial sections, GK.D 13660a and 13662 from Kpp-50, GK.D 13685, 13982 and 14079 from Kpp-51, GK.D 13734 from Kpp-54, GK.D 13435 from Kpp-58; sagittal section, GK.D 13062 from Kpp-30.

Description:-Shell small and ellipsoidal, with straight axis of coiling, exclusively convex lateral slopes and broadly rounded and slightly umbilicated poles. Mature shell of 10 to 11 volutions is 3.53 to $3.9 \pm \mathrm{mm}$ in length and 2.95 to $3.29 \mathrm{~mm}$ in width, with a form ratio of 1.20 to 1.24. The innermost volution evolutes, with a short axis of coiling which makes large angles to that of the outer volutions. Beyond the second volution, shell coils planispirally and nearly the same in axial profile. Ratios of half length to radius vector of the second to tenth volutions in a typical axial section (GK.D 13662) are 1.36, 1.37, 1.53, 1.48, 1.40, 1.28, 1.15, 1.09, 1.07 , and 1.07 , respectively.

Proloculus minute and spherical, with outside diameter of 32 to 65 microns, averaging 47 microns in six specimens. Shell coils tightly in inner three to four volutions, but expands relatively rapidly and uniformly in outer volutions. Average radius vectors of the first to tenth volutions in six specimens are $68,108,171$, $269,402,570,753,973,1142$, and 1406 microns, respectively. Chambers are almost the same in height from pole to pole except in inner volutions.

Spirotheca relatively thick and consists of a tectum and a keriotheca with very fine alveolar structure. In the first one to two volutions spirotheca seems to be composed of a single thin layer in which no minute structure is observed. Thicknesses of spirotheca in the first to tenth volutions in three specimens average $10,1316,21,21,25,25,26,25$, and 25 microns, respectively.

Parachomata do not present in inner two to three volutions, but they begin 
Table 20. Measurements of Verbeekina (Armenia) sphaera OzAWA (in mm. unless otherwise stated)

\begin{tabular}{|c|c|c|c|c|c|c|c|c|c|c|c|c|c|c|c|c|c|c|c|c|c|c|c|}
\hline \multirow{2}{*}{$\begin{array}{c}\text { Speci- } \\
\text { men }\end{array}$} & \multirow{2}{*}{$\begin{array}{l}\text { Rg. no. } \\
\text { GK.D }\end{array}$} & \multirow{2}{*}{\multicolumn{2}{|c|}{$\begin{array}{l}\text { No. } \\
\text { vol. }\end{array}$}} & \multirow{2}{*}{ L. } & \multirow{2}{*}{\multicolumn{2}{|c|}{ W. }} & \multirow{2}{*}{ Fr. } & \multirow{2}{*}{ Prol. } & \multicolumn{15}{|c|}{ Radius vector } \\
\hline & & & & & & & & & & 1 & 2 & 3 & 4 & 5 & 5 & 6 & 7 & & 8 & 9 & & 10 & 11 \\
\hline 1 & 1366 & & 11 & $3.9 \pm$ & 3.2 & & 1.19 & $.032 ?$ & & - & .109 & .175 & .240 & .34 & & .528 & .725 & & 973 & 1.215 & 1.47 & & 1.712 \\
\hline 2 & 1407 & & 10 & 3.53 & 2.9 & & 1.20 & $.04 ?$ & .04 & 49 & .085 & .129 & .196 & .33 & & .495 & .681 & & 906 & 1.122 & 1.32 & & \\
\hline 3 & 1314 & & 9 & $2.45 ?$ & 1.9 & & 1.26 & $.045 ?$ & .05 & 53 & .098 & .143 & .235 & .34 & & .489 & .636 & & $825 ?$ & 1.017 & & & \\
\hline 4 & 1343 & & 7 & 2.70 & 1.5 & & 1.80 & $.056 ?$ & .09 & 92 & .112 & 192 & .320 & .45 & & .609 & .770 & & & & & & \\
\hline 5 & 1314 & & 8 & 2.52 & 2.2 & & 1.12 & .050 & .06 & 65 & 111 & .175 & .287 & .45 & & .643 & .864 & & 120 & & & & \\
\hline 6 & 1306 & & 10 & - & 2.7 & & - & $.05 ?$ & .08 & 80 & .133 & .213 & .333 & .47 & & .654 & .839 & & 040 & 1.215 & 1.41 & & \\
\hline \multirow{2}{*}{$\begin{array}{c}\text { Speci- } \\
\text { men }\end{array}$} & \multicolumn{11}{|c|}{ Ratio of half length to radius vector } & \multicolumn{11}{|c|}{ Thickness of spirotheca (in micron) } & \multirow{2}{*}{$\begin{array}{l}\text { Pl. } 14 \\
\text { Fig. }\end{array}$} \\
\hline & 1 & 2 & 3 & 4 & 5 & 6 & 7 & 8 & 9 & 10 & 11 & 1 & 2 & 3 & 4 & 5 & 6 & 7 & 8 & 9 & 10 & 11 & \\
\hline 1 & - & 1.36 & 1.37 & 1.53 & 1.48 & 1.40 & $0 \quad 1.28$ & 1.15 & 1.09 & $1.0^{7}$ & $7 \quad 1.07$ & - & 17 & 19 & 22 & 21 & 22 & 23 & 23 & 23 & 24 & 24 & 1 \\
\hline 2 & - & 1.06 & 1.13 & 1.23 & 1.19 & 1.20 & 1.22 & 1.24 & 1.23 & 1.25 & & 7 & 10 & 14 & - & 18 & 28 & 29 & 29 & 32 & 31 & & 2 \\
\hline 3 & 1.36 & 1.22 & 1.40 & 1.32 & 1.35 & 1.33 & $\begin{array}{ll}3 & 1.32\end{array}$ & 1.26 & 1.22 & & & - & 11 & 11 & 14 & 16 & 18 & 19 & 20 & 22 & & & 3 \\
\hline 4 & 0.98 & 1.43 & 1.54 & 1.50 & 1.52 & 1.60 & 1.62 & & & & & 13 & 16 & 17 & 23 & 23 & 28 & 24 & & & & & 5 \\
\hline 5 & 1.00 & 1.00 & 1.10 & 1.22 & 1.17 & 1.19 & $\begin{array}{ll}9 & 1.17\end{array}$ & 1.14 & & & & 11 & 12 & 16 & 20 & 23 & 32 & 34 & 33 & & & & 6 \\
\hline 6 & & & & & & & & & & & & - & 11 & 18 & 21 & 22 & 23 & 22 & 23 & 29 & 20 & & 10 \\
\hline \multirow{2}{*}{$\begin{array}{c}\text { Speci- } \\
\text { men }\end{array}$} & \multicolumn{14}{|c|}{ Septal count } & & & & & & & & & \\
\hline & 1 & & 2 & 3 & 4 & & 5 & 6 & 7 & & 8 & 9 & 10 & & & & & & & & & & \\
\hline 6 & - & & $10 ?$ & $10 ?$ & 10 & & 13 & 12 & 14 & & 16 & 19 & - & & & & & & & & & & \\
\hline
\end{tabular}


to appear in the third or fourth volution, being relatively massive with a height about one-third to a half of chamber height in several middle volutions and about one-fourth to one-third in outer volutions.

Septa thin and the same in structure as spirotheca. Septal counts of the second to ninth volutions in a sagittal (somewhat excentric) section (GK.D 13062) are 10 ?, 10 ?, 10,13,12,14, 16, and 19 , respectively.

Remarks:-Since Verbeekina (Armenia) sphaera bears an important significance in consideration on the phylogeny of the genus Verbeekina and its allied forms, SugI (1960) studied in detail his hypotypes of the species from the Cancellina nipponica zone (Nn zone) of the Akasaka Limestone along with the original specimens of OzAWA kept in the University of Tokyo. To avoid future confusion, SugI designated the lectotype of the species among the OzAWA's syntype, but he did not give a description of the lectotype itself. Such was the case, KANMERA (1963) described the lectotype together with many specimens collected from the Kozaki Formation in South Kyushu.

The Khao Phlong Phrab specimens, though not sufficient in number, are almost identical in essential shell characteristics with the Kozaki specimens, but a little larger in shell size than the lectotype and the hypotypes from the Akasaka Limestone and also the specimens described by CHEN (1956) from the Maokou Limestone of Shangchin and Lingyün, Kwangsi. Les prominent development and discontinuity of parachomata in central part of chamber in inner volutions of the Kozaki specimens are accelerated in the Khao Phlong Phrab specimens. However, these difference are considered to be a variation within the species.

Occurrence:-Relatively abundant at $\mathrm{Kpp}-50$; common at $\mathrm{Kpp}-30,-46,-51$; rare at $\mathrm{Kpp}-27 \mathrm{a},-42,-49,-53,-54,-57$, and -58 . The $B_{4}$ to $B_{6}$ zones.

\section{Subgenus Verbeekina STAFF, 1909 \\ Verbeekina (Verbeekina) verbeeki (GEINITZ) Pl. 14, Fig. 12}

1876. Fusulina verbeeki GeINITz. Palaeontographica, Bd. 22, p. 399-400.

1909. Schwagerina verbeeki StAFF. Neues Jahrb. Min. Geol. Palaeont. Beil.-Bd 27, p. 506, pl. 7, figs. 5,7 .

1912. Schwagerina verbeeki DEPRAT. Mém. Serv. Géol. l'Indochine, tome 1, fasc. 3, p. 40-41, Text-fig. 24, pl. 1, fig. 7-11.

1925. Verbeekina verbeeki OzAwA. Jour. Coll. Sci. Imp. Univ. Tokyo, Sect. 2, vol. 2, pt. 3, p. 48-51, pl. 10, figs. 6-7.

1929. Verbeekina verbeeki OzaWA and TOBLer. Ecol. Geol. Helvetiae, p. 48, pl. 5, fig. 5.

1934. Verbeekina verbeeki Chen. Palaeont. Sinica, Ser. B, vol. 4, fasc. 2, p. 101102, pl. 16, fig. 1.

1936. Verbeekina verbeeki THомpson. Jour. Paleont., vol. 10, no. 3, p. 197-200, pl. 24, figs. 1-8.

1936. Verbeekina verbeeki Huzıмoto. Sci. Rept. Tokyo Bunrika Daigaku, Sec. C, vol. 1, no. 2, p. 101-104, pl. 9, fig. 8; pl. 21, figs. 1-3.

1955. Verbeekina verbeeki KOCHANSKY-DÉvIDE and RAMOVS. Slovenska Akad. Znanosti in Umetn. Akad. Sci. Art. Slovenica, Cl. 4, Razürave Dissert., p. 389, 416, pl. 4, figs. 1-3.

1957. Verbeekina verbeeki MıкLUкно-MakLAY. Uchenye Zapiski, Lgu, no. 225, p. 113-114, pl. 3, fig. 2. 
Table 21. Measurements of Verbeekina (Verbeekina) verbeeki (GEINITZ) (in mm. unless otherwise stated)

\begin{tabular}{|c|c|c|c|c|c|c|c|c|c|c|c|c|c|c|c|c|c|c|c|}
\hline \multirow{2}{*}{$\begin{array}{c}\text { Spect- } \\
\text { men }\end{array}$} & \multirow{2}{*}{$\begin{array}{c}\text { Rg. no. } \\
\text { GK.D }\end{array}$} & \multirow{2}{*}{$\begin{array}{l}\text { No. } \\
\text { vol. }\end{array}$} & \multirow{2}{*}{ L. } & \multirow{2}{*}{ W. } & \multirow{2}{*}{ Fr. } & \multirow{2}{*}{ Prol. } & \multicolumn{13}{|c|}{ Radius vector } \\
\hline & & & & & & & 1 & 2 & 3 & 4 & 5 & 6 & 7 & 8 & 9 & 10 & 11 & 12 & 13 \\
\hline 1 & 13816 & 13 & 5.32 & 5.48 & 0.97 & - & .095 & .159 & .241 & .368 & .545 & .792 & 1.055 & 1.312 & 1.601 & 11.856 & 2.120 & 2.420 & 2.670 \\
\hline \multirow{2}{*}{$\begin{array}{c}\text { Speci- } \\
\text { men }\end{array}$} & \multicolumn{15}{|c|}{ Ratio of half length to radius vector } & \multirow{2}{*}{$\begin{array}{l}\text { Pl. } 14 \\
\text { Fig. }\end{array}$} & & & \\
\hline & 1 & 2 & 3 & 4 & 5 & 6 & 7 & 8 & 9 & & 10 & 11 & 12 & 18 & 3 & & & & \\
\hline 1 & 0.84 & 0.91 & 1.03 & 1.05 & 1.17 & 1.11 & 1.09 & 1.04 & 1.00 & & 1.01 & 1.00 & 0.98 & 0.9 & & 12 & & & \\
\hline \multirow{2}{*}{$\begin{array}{c}\text { Speci- } \\
\text { men }\end{array}$} & \multicolumn{15}{|c|}{ Thickness of spirotheca (in micron) } & & & & \\
\hline & 1 & 2 & 3 & 4 & 5 & 6 & 7 & 8 & 9 & & 10 & 11 & 12 & 13 & 3 & & & & \\
\hline 1 & - & 11 & 13 & 14 & 17 & 17 & 19 & 21 & 25 & & 29 & 29 & 32 & 32 & & & & & \\
\hline
\end{tabular}


1957. Verbeekina verbeeki KoвayASHI. Sci. Repts Tokyo Kyoiku Daigaku, Sect. C, no. 48, p. 301-302, pl. 9, figs. 5-7.

1958. Verbeekina verbeeki TORIYAMA. Mem. Fac. Sci. Kyushu Univ., Ser. D, Geol., vol. 7, p. 205-208, pl. 37, figs. 1-6; pl. 38, figs. 1-6.

1961. Verbeekina verbeeki Nogami. Mem. Coll. Sci. Univ. Kyoto, Ser. B, vol. 28, no. 2, art. 3, p. 167-169, pl. 2, figs. 1-4.

1963. Verbeekina verbeeki Sheng. Palaeont. Sinica, N.S., B, no. 10, 215-216, pl. 26, figs. 1-5.

1964. Verbeekina verbeeki IGo. Japan. Jour. Geol. Geogr., vol. 35, no. 1, p. 62-63, pl. 2, fig. 1.

1964. Verbeekina verbeeki IshII and Nogami. Jour. Geosci. Osaka City Univ., vol. 8, art. 2, p. 24, pl. 8, figs. 4-6.

1965. Verbeekina verbeeki forma A, PitakPaIVAN. Mem. Fac. Sci. Kyushu Univ., Ser. D, Geol., vol. 17, no. 1, p. 53-54, pl.6, fig. 5.

1967. Verbeekina verbeeki LEVEN. Acad. Sci. USSR, Geol. Inst., Transact., vol. 167, p. 205, pl. 28, fig. 1.

Material:-Axial section, GK.D 13816 from Kpp-76.

Descriptive remarks:-Verbeekina verbeeki, one of the best known Middle Permian species of verbeekinids, has been reported by many previous workers from various localities in the Tethys realm. In Thailand and her adjacent areas, the present species has been described in the last decade from the Maoteetang hill, near Khao Phlong Phrab (PitakPaivan, 1965), Ulu Sungei Atok in northern Pahang (Igo, 1964) and Phnom Bak, Sisophon, Cambodia (IsHII and NogAmI, 1964).

Although the Khao Phlong Phrab specimen is represented by only a single axial section, it is typical in essential biocharacters for the species. However, the present material is too insufficient to give detailed specific description, and the mensural data on this specimen is only given.

Occurrence:-Only known at Kpp-76. The middle part of the $B_{7}$ zone.

Subgenus Paraverbeekina MIKLukho-MakLaY, 1955

Verbeekina (Paraverbeekina) pontica MIKLUKHo-MAKLAY

Pl. 14, Figs. 13-15

1955. Paraverbeekina pontica MiLukho-MakLay. Dokl. Akad. Nauk. USSR, vol. 105, no. 3, p. 574, text-fig. $1 \mathrm{~b}$.

1957. Paraverbeekina pontica Mrknukho-Maklay. Uchenye Zapiski Lgu, Ser. Geol. Nauk, vol. 9 (no. 225), p. 114-115, pl. 3, fig. 6.

Material:-Axial section, GK.D 13837 from Kpp-75; tangential section, GK.D 14047 from Kpp-82; excentric section, GK.D 13840a from Kpp-75.

Description:-Shell large and ellipsoidal to more or less elongate melon shape, with straight axis of coiling, exclusively convex lateral slopes and broadly rounded poles. Mature specimen of 13 volutions attains a length of $5.20 \mathrm{~mm}$ and a width of $3.94 \mathrm{~mm}$, with a form ratio of 1.32 . Although the axial section (GK.D 13837) is not cut exactly through the center of shell, it seems that the first volution coils askew to the later volutions. From the second volution to the maturity, shell is nearly the same in axial profile. Ratios of half length to radius vector of the second to thirteenth volutions in the axial section are $1.46,1.60,1.49,1.35,1.30,1.34$, $1.31,1.24,1.28,1.27,1.26$, and 1.27 , respectively. 
Proloculus seems to be very small, probably having outside diameter of less than 45 microns. Shell coils slowly in the first two volutions and relatively rapidly and almost uniformity from the third volution to the maturity. Radius vectors of the first to thirteenth voluions in the axial secion measure 55?, 72?, 120, 215, $368,545,730,930,1170,1365,1608,1824$, and 2045 microns, respectively. Chamber is almost the same in height from pole to pole in each volution.

Spirotheca relatively thin, and consists of a tectum and a keriotheca. In the latter very fine alveoli are discernible throughout the growth. Thickness of spirotheca of the second to thirteenth volutions in the axial section are 12, 12, 13, 14, $17,17,17,19,18,20,23$, and 29 microns, respectively.

Parachomata very rudimentary in development. They are not present in inner four volutions. Beyond the fifth volution they are very low and broad, if exist, with a height about one-fifth or one-sixth of chamber height. Moreover, they are not developed in outer volutions except for a very limited part.

Remarks:-Verbeekina (Paraverbeekina) pontica was established by MIKLUKHO-MAKLAY (1955) based on a single axial (more or less tangential) section. The present materials are also insufficient in number, but their essential shell characters are almost identical with those of the type specimen of MIKLUKHoMAKLAY.

The genus Paraverbeekina was established by MikLukHo-MaKLAY with $P$. pontica as the type-species for elongate form of Verbeekina. However, as discussed by KANMERA (1963) there is no essential difference in shell characters between Verbeekina and Paraverbeekina except for elongate form of the latter. OzAWA (1970), therefore, regarded Paraverbeekina as a junior synonym of Verbeekina. In this paper, the writer follows KANMERA (1963) and KAHLER and KAHLER (1966) in placing Paraverbeekina as a subgenus of Verbeekina only from the stand-point of convenience for the morphological distinction, until the phylogenetical relationship among verbeekines is clearly understood.

Occurrence:-Rare at Kpp-52, -55, -75 and -82. The $\mathrm{B}_{6}$ and $\mathrm{B}_{7}$ zones.

Subfamily Pseudodoliolininae Leven, 1963

Genus Pseudodoliolina YABE and HANZAWA, 1932

\section{Pseudodoliolina sp. A \\ Pl. 14, Figs. 17-18}

Material:-Axial (slightly tangential) section, GK.D 13321 from Kpp-22; tangential sections, GK.D 13206 from Kpp-18 and 13270 from Kpp-27a; sagittal (more or less diagonal) section, GK.D 13276 from Kpp-27b.

Description:-Shell small and elongate cylindrical with straight axis of coiling, flat median portion, and broadly rounded polar extremities. Mature shell of $6 \frac{1}{2}$ to 8 volutions attains a length of 2.45 to $2.85 \mathrm{~mm}$ and a width of 0.67 to $0.96 \mathrm{~mm}$, giving a form ratio of 3.66 to 3.99 . Although no exactly oriented axial section has been available, axis seems to expand polewards considerably rapidly. Ratios of half length to radius vector of the first to sixth volutions in three specimens average $2.24,2.73,3.04,3.37,3.50$, and 3.75 , respectively.

Proloculus minute and spherical to subspherical, with approximate outside diameter of 47 ? to 83 microns. Shell coils tightly in the first volution, and expands slowly and almost uniformly from the second volution to the maturity. 
Table 22. Measurements of Pseudodoliolina sp. A (in mm. unless otherwise stated)

\begin{tabular}{|c|c|c|c|c|c|c|c|c|c|c|c|c|c|c|c|c|}
\hline \multirow{2}{*}{$\begin{array}{c}\text { Speci- } \\
\text { men }\end{array}$} & \multirow{2}{*}{$\begin{array}{c}\text { Rg.no. } \\
\text { GK.D }\end{array}$} & \multirow{2}{*}{$\begin{array}{l}\text { No. } \\
\text { vol. }\end{array}$} & \multirow{2}{*}{ L. } & \multirow{2}{*}{ W. } & \multirow{2}{*}{ Fr. } & \multirow{2}{*}{ Prol. } & \multicolumn{9}{|c|}{ Radius vector } & \multirow{2}{*}{$\begin{array}{l}\text { Pl. } 14 \\
\text { Fig. }\end{array}$} \\
\hline & & & & & & & 1 & 2 & \multicolumn{2}{|c|}{3} & 4 & ector & 6 & 7 & 8 & \\
\hline 1 & 1.3321 & $6 \frac{1}{2}$ & 2.67 & 0.60 & 3.99 & $.047 ?$ & .067 & .103 & & & .210 & .268 & .323 & $.345^{*}$ & & 17 \\
\hline 2 & 13206 & $6 \frac{1}{2}$ & 2.85 & 0.73 & 3.90 & - & .065 & .107 & & & .199 & .257 & .333 & $.385^{*}$ & & 18 \\
\hline 3 & 13270 & 7 & 2.45 & 0.67 & 3.66 & - & .060 & .097 & & & .184 & .232 & .306 & .384 & & \\
\hline 4 & 13276 & 8 & - & 0.96 & - & .058 & .064 & .114 & & & .221 & .275 & .344 & .406 & .520 & \\
\hline \multirow{2}{*}{$\begin{array}{l}\text { Speci- } \\
\text { men }\end{array}$} & \multicolumn{7}{|c|}{ Ratio of half length to radius vector } & \multicolumn{8}{|c|}{ Thickness of spirotheca (in micron) } & \\
\hline & 1 & 2 & 3 & 4 & 5 & 6 & 7 & 1 & 2 & 3 & 4 & 5 & 6 & 7 & 8 & \\
\hline 1 & 2.94 & 3.15 & 3.30 & 3.33 & 3.54 & 4.09 & - & 13 & 13 & 13 & 14 & 16 & - & & & \\
\hline 2 & 2.00 & 2.71 & 2.91 & 3.47 & 3.46 & 3.93 & $3.74^{*}$ & - & 12 & 13 & 13 & 14 & 15 & $15^{*}$ & & \\
\hline 3 & 1.77 & 2.33 & 2.92 & 3.32 & 3.51 & 3.24 & 3.18 & 12 & 13 & 14 & 14 & 14 & 16 & - & & \\
\hline 4 & & & & & & & & - & 9 & 10 & 10 & 12 & 12 & 12 & - & \\
\hline \multirow{2}{*}{$\begin{array}{c}\text { Speci- } \\
\text { men }\end{array}$} & \multicolumn{8}{|c|}{ Septal count } & & & & & & & & \\
\hline & 1 & 2 & 3 & 4 & 5 & 6 & 7 & 8 & & & & & & & & \\
\hline 4 & - & - & $10 ?$ & 12 & 14 & 16 & $16 ?$ & - & & & & & & & & \\
\hline
\end{tabular}

* measured a half volution earlier than others in the same column. 
Average radius vectors of the first to seventh volutions in four specimens 64,105 , 149, 204, 258, 327, and 395 microns, respectively. Chambers almost the same in height in central half of shell, but rapidly increases poleward in both extremities.

Spirotheca thin, composed apparently of a single homogeneous layer in which no fine structure can be observed. Thicknesses of spirotheca of the first to sixth volutions in four specimens average $12,12,12,13,14$, and 13 microns, respectively.

Septa rather thick and the same in structure as spirotheca. They are widely spaced, with septal counts of 10 ?, 12,14,16, and 16 ? in the third to seventh volutions in one specimen.

Parachomata not present in inner three volutions. They first appear in the fourth volution, but very low and primitive in character and very widely spaced. In the fifth to seventh volutions they are semi-circular in axial profile and about a half as high as chamber. About 20 parachomata present in the sixth volution of one specimen.

Remarks:-Pseudodoliolina sp. A is not comparable with any species of the genus previously described. It may be a new species, but the present material at hand is too insufficient to establish a new species. Further study on enough material is necessary before the diagnostic characteristics of the present species is fixed.

The present species is very small in size for the genus Pseudodoliolina, and very primitive in shell characteristics. It is assumed to be an earlier representative in the phylogenetic stock of pseudodoliolinids. The stratigraphic position of the present species is in harmony with the primitiveness of shell characteristics.

Occurrence:-Rare at Kpp-18, -20, -22, -23, -27a, and -27b. The upper half of the $B_{2}$ zone to the lower part of the $B_{4}$ zone.

\section{Pseudodoliolina saraburiensis TORIYAMa and KaNMERA, n. sp. Pl. 14, Figs. 19-22; Pl. 15, Figs. 1-7}

Material:-Holotype, GK.D 13059a from Kpp-30 (Microspheric form) : Paratypes, axial sections, GK.D 13108 from Kpp-24, GK.D 13028 from Kpp-35, GK.D 13013 from Kpp-37, GK.D 13337 from Kpp-44a, and GK.D 13641 from Kpp-47; sagittal section, GK.D 13059a from Kpp-30, and 13338 from Kpp-44a.

Description:-Shell small and short cylindrical, with almost flat median portion and broadly rounded poles. The holotype specimen of nine volutions is $2.50 \mathrm{~mm}$ in length and $1.19 \mathrm{~mm}$ in width, with a form ratio of 2.10 . Dimorphism is observed. Microspheric form has an endothyroid juvenarium of one volution whose axis is nearly perpendicular to that of later volutions. From the second volution shell assumes a short cylindrical form, although the extension of axis towards pole becomes rather slower in outer volutions. Ratios of half length to radius vector of the first to tenth volutions in eight specimens average 1.78, 1.95, 2.01, $2.10,2.11,2.08,2.07,2.01,1.91$, and 1.95 , respectively.

Proloculus is minute and spherical in microspheric form with outside diameter of 53 microns in the holotype. It is spherical to subspherical in megalospheric form, having an average of 100 microns in eight specimens. Shell expands uniformly and slowly. Radius vectors of the first to ninth volutions in ten specimens are $76,109,155,206,262,337,419,503$, and 599 microns, respectively in average.

Spirotheca is thin and consists of a tectum and lower less dense layer, in the 
Table 23. Measurements of Pseudodoliolina saraburiensis Toriyama and Kanmera, n. sp. (in mm. unless otherwise stated)

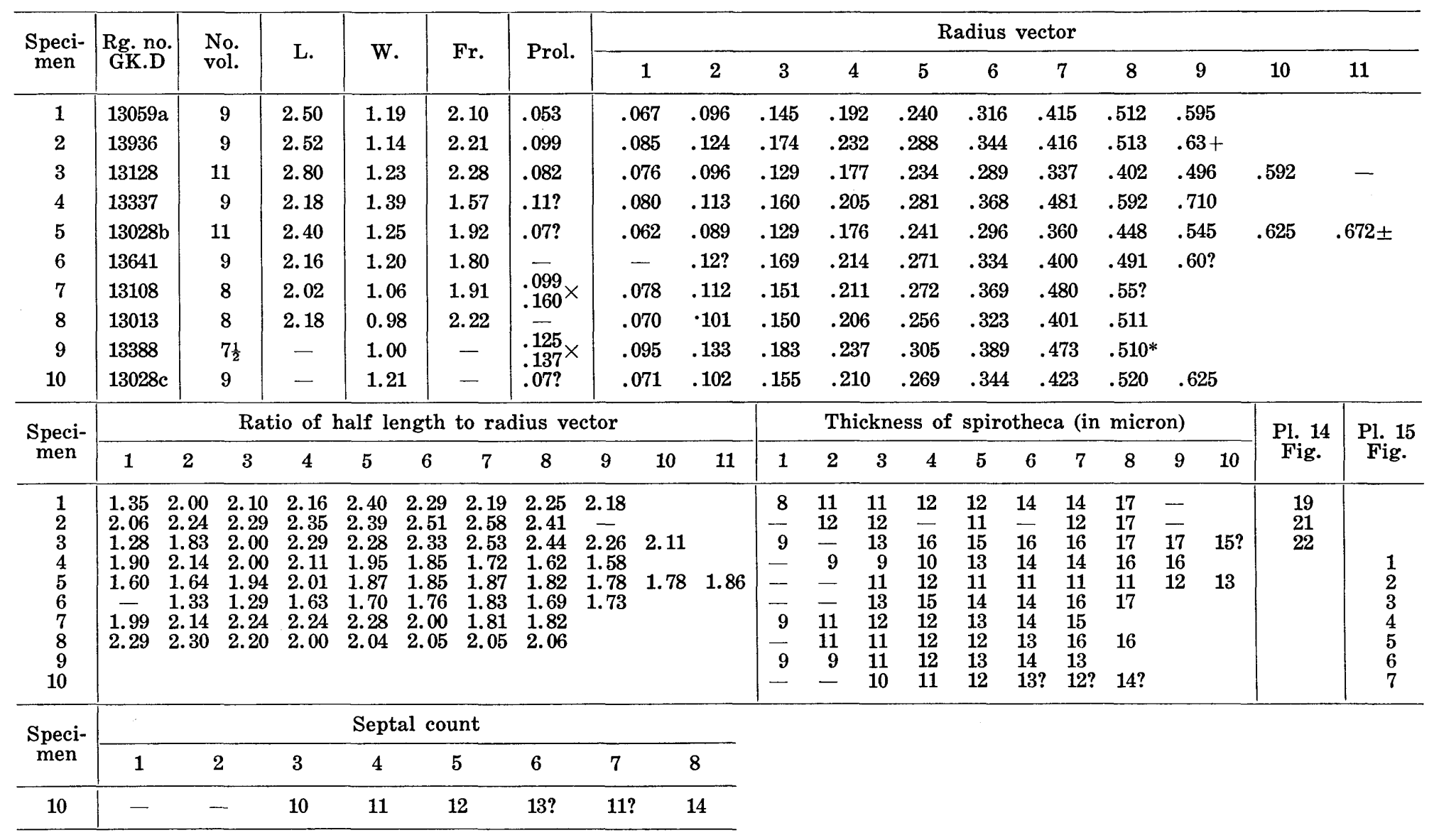

* measured a half volution earlier than others in the same column. 
latter of which very fine alveolar structure is discernible in parts of outer volutions. Average thicknesses of spirotheca in the first to ninth volutions in ten specimens are $9,11,12,12,13,14,14,16$, and 15 microns, respectively. Septa are composed of the downward deflection of spirotheca and considerably thick.

Parachomata well developed throughout the length of shell, except in the first two volutions. They are low and broad in inner volutions, being about a half as high as chambers. In outer volutions they become partly a little higher and narrower.

Remarks:-Pseudodoliolina saraburiensis $\mathrm{n}$. $\mathrm{sp}$. is a primitive representative of the genus. The small and short cylindrical form of shell suggests that the present species is an ancestral form of Metadoliolina pinguis n. sp. . Any species so far has been known is not comparable with the present species.

Occurrence:-Common at Kpp-30, -38 and -39 ; rare at $\mathrm{Kpp}-24,-29,-35,-36$, $-37,-44 a$, and -47 . The uppermost part of the $B_{3}$ to the lower half of the $B_{5}$ zone.

Pseudodoliolina primigena TORIYAMA and KANMERA, n. sp. Pl. 15, Figs. 8-18

Material:-Holotype, GK.D 13145c from Kpp-35. Paratypes, axial sections, GK.D 13022a from Kpp-35, GK.D 13912, 13921, and 13930 from Kpp-38, GK.D 13076 and 13130 from Kpp-39, GK.D 13692a from Kpp-51, GK.D 13564a from Kpp-52; sagittal sections, GK.D 13940 from Kpp-38, and many other sectioned specimens.

Description:-Shell small and elongate cylindrical, with broadly rounded poles. Mature shell of ten to eleven volutions has a length of 2.75 to $3.20 \mathrm{~mm}$ and a width of 1.00 to $1.41 \mathrm{~mm}$, giving a form ratio of 2.75 to 3.47 . The first volution spherical to subspherical, and the second volution short cylindrical in some specimens. From the second or third volution, shell assumes typical cylindrical shape. Ratios of half length to radius vector in the first to tenth volutions in eight mature specimens average $1.73,2.27,2.56,2.70,2.85,2.91,2.81,2.80,2.71$, and 2.59 , respectively.

Proloculus small and spherical to subspherical. Maximum outside diameter is 129 microns in spherical form, and 104 microns in subspherical form. Minimum one is 64 microns in the former and 47 microns in the latter. Shell expands gradually and uniformly in inner four to six volutions and a little rapidly in outer three or four volutions. Average radius vectors of the first to ninth volutions in nine specimens are $74,103,141,181,235,295,369,429$, and 508 microns, respectively.

Spirotheca very thin and compose apparently of a single layer in inner volutions in which alveolar structure is hardly discernible. However, it consists of a tectum and a lower less dense layer in a limited part of outer volutions of some specimens where the spirotheca is a little thickened and a faint minute structure like alveoli is seen. Average thickness of spirotheca for the first to ninth volutions in nine specimens is $9,10,10,12,13,14,14,15$, and 14 microns, respectively.

Septa thick and widely spaced. Septal count of the first to ninth volutions in a specimen is $5,9,12,14,13,14,16,14$, and 14 ?, respectively. Parachomata do not present in the first two or three volutions. They are very incipient in occurrence in the following two or three volutions, being very broad and low, and widely spaced. In the outer volutions parachomata well developed, and semi-circular in axial profile, and about a half or a little higher than half as high as chambers.

Remarks:-Although Pseudodoliolina primigena $\mathrm{n}$. sp. is not comparable with 
Table 24. Measurements of Pseudodoliolina primigena TORIYAMA and KaNMERA, n. sp. (in mm. unless otherwise stated)

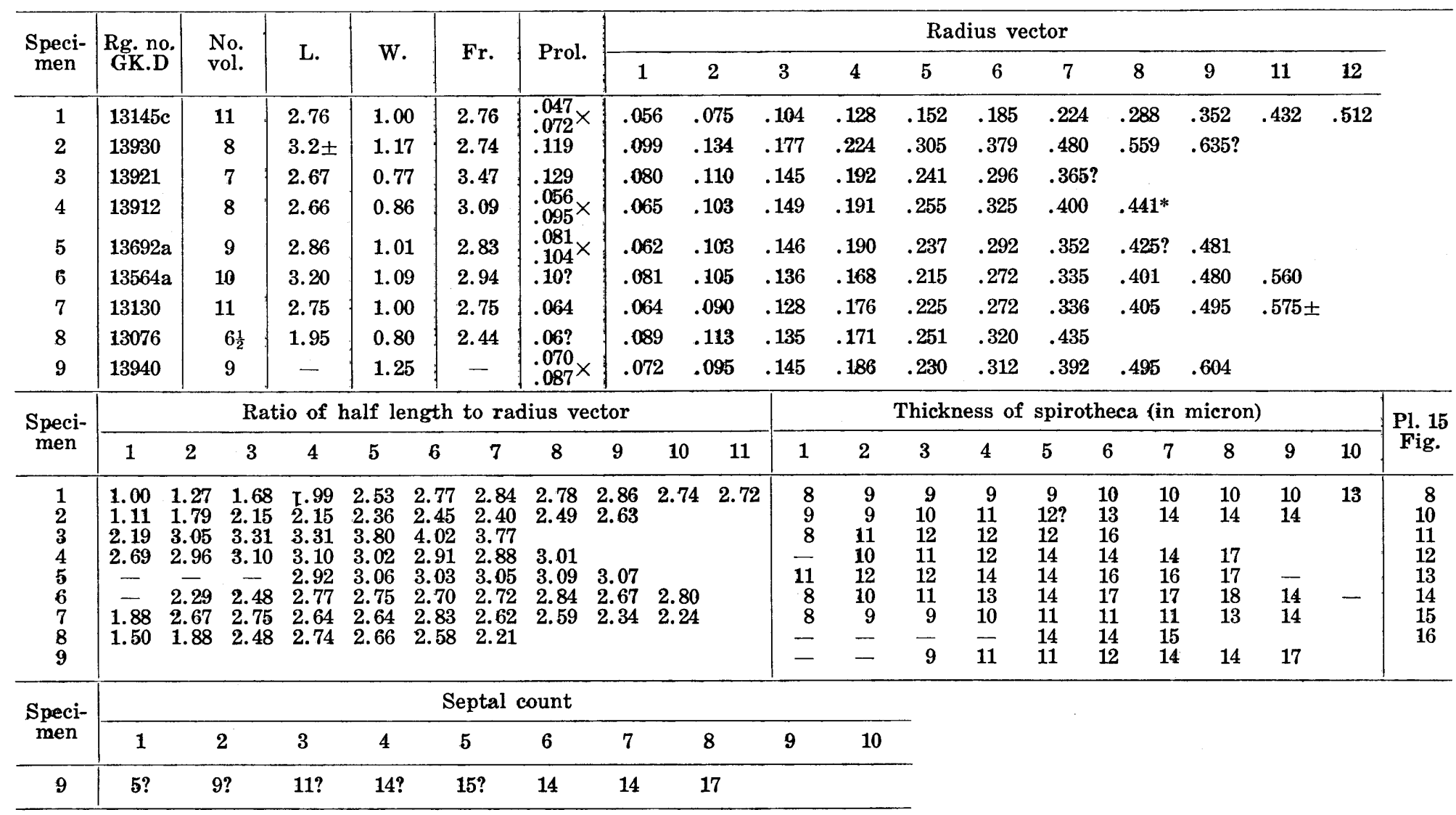

* measured a half volution earlier than others in the same column. 
any species previously known, the small and elongate subcylindrical form of shell, the absence of parachomata in the earlier stage of growth, and thinness of spirotheca suggest that the present species is a primitive representative of the genus Pseudodoliolina. It is probably a direct ancestral form of $P$. gracilis n. sp., from the latter, in turn, $P$. ozawai ozawai and $P$. ozawai minima are derived.

Occurrence:-Abundant at $\mathrm{Kpp}-38$; common at $\mathrm{Kpp}-35,-39,-51,-52$, and -54 . The upper part of the $B_{4}$ to the lower part of the $B_{6}$ zone.

\section{Pseudodoliolina gracilis TORIYAMA and KANMERA, n. sp. Pl. 15, Figs. 19-24}

Material:-Holotype, GK.D 13741 from Kpp-54. Paratypes, axial sections, GK.D 13906 from Kpp-38 and GK.D 13967 from Kpp-42; sagittal section, GK.D 13935 from Kpp-38.

Description:- Shell small and elongate cylindrical, with broadly rounded poles. Median two-thirds of shell is almost straight cylindrical. The holotype specimen of nine volutions attains a length of $3.53 \mathrm{~mm}$ and a width of $1.02 \mathrm{~mm}$, with a form ratio of 3.46. The first volution ellipsoidal to fusiform with rather narrowly rounded poles. The second volution elongate fusiform, and shell assumes mature shell form from the third volution. Ratios of half length to radius vector of the first to ninth volutions of the holotype specimen are $2.92,3.24,3.54,3.81,3.64$, $3.39,3.45,3.51$, and 3.33 , respectively.

Proloculus minute and subspherical with outside diameter of $120 \times 85$ microns in the holotype specimen. Expansion of shell is very slow in inner three volutions, and becomes less slow and uniform in outer ones. Radius vectors of the first to ninth volutions in three axial sections average $60,83,112,155,207,263,332,299$, and 505 microns, respectively. Chambers are nearly the same in height in the cylindrical part of shell, but increase in height rapidly in polar regions.

Spirotheca thin and consists of a tectum and a lower less dense layer, in the latter of which no clear structure is recognizable, but very fine alveolar structure is observed in a limited part of outer volutions. Thickness of spirotheca of the first to ninth volutions in three specimens average $9,10,11,11,12,12,12,15$, and 15 microns, respectively.

Parachomata do not occur in inner two or three volutions, and in the following one or two volutions they are very incipient in development, being only a widely spaced low deposits on the upper surface of spirotheca. In outer volutions parachomata are well developed, with nearly semi-circular in axial profile and about a half of chamber height. About 50 parachomata occur in the eighth volution of the holotype specimen.

Remarls:-Pseudodoliolina gracilis n. sp. is new to science, having a small and very elongate shell, very slow expansion of shell, and absence of parachomata in inner volutions. Considering these characteristics, the present species is a primitive representative of the genus $P$ seudodoliolina, and it is a transitional form from $P$. primigena to $P$. ozawai minima. From phylogenetical point of view, an evolutionary lineage, $P$. primigena $-P$. gracilis $-P$. ozawai minima $-P$. ozawai ozawai-P. pseudolepida is suggested.

Occurrence:-Common at Kpp-38; rare at Kpp-42 and -54. The uppermost part of the $B_{4}$ to the lower half of the $B_{6}$ zone. 
Table 25. Measurements of Pseudodoliolina gracilis TORIYAMA and KANMERA, n. sp. (in mm. unless otherwise stated)

\begin{tabular}{|c|c|c|c|c|c|c|c|c|c|c|c|c|c|c|c|c|c|c|c|c|c|}
\hline \multirow{2}{*}{$\begin{array}{c}\text { Speci- } \\
\text { men }\end{array}$} & \multirow{2}{*}{$\underset{\text { GK. no. }}{\text { Rg. no. }}$} & \multirow{2}{*}{\multicolumn{2}{|c|}{$\begin{array}{l}\text { No. } \\
\text { vol. }\end{array}$}} & \multirow{2}{*}{ L. } & \multirow{2}{*}{ W. } & \multirow{2}{*}{\multicolumn{2}{|c|}{ Fr. }} & \multirow{2}{*}{ Prol. } & \multicolumn{13}{|c|}{ Radius vector } \\
\hline & & & & & & & & & \multicolumn{5}{|c|}{3} & 4 & 5 & \multicolumn{2}{|c|}{6} & 7 & 8 & 9 & 10 \\
\hline 1 & 13741 & & 9 & 3.53 & 1.02 & & 3.46 & $.085 x$ & & .060 & .088 & \multicolumn{2}{|c|}{.113} & .166 & .220 & \multicolumn{2}{|c|}{.287} & .351 & .415 & .510 & \\
\hline 2 & 13906 & & 9 & 3.70 & 0.85 & & 4.35 & $.066 \times$ & & .060 & .080 & \multicolumn{2}{|c|}{$\cdot 104$} & .131 & .168 & \multicolumn{2}{|c|}{.211} & .275 & .352 & .475 & \\
\hline 3 & 13967 & & 10 & 4.06 & 1.13 & & 3.59 & $.05 ?$ & & - & .081 & \multicolumn{2}{|c|}{.119} & .167 & .231 & \multicolumn{2}{|c|}{.289} & .367 & .431 & .530 & $.61 ?$ \\
\hline 4 & 13935 & & 10 & - & 1.41 & & - & .112 & & .085 & .125 & .16 & & 199 & .254 & \multicolumn{2}{|c|}{.335} & .416 & .495 & .592 & .730 \\
\hline \multirow{2}{*}{$\underset{\text { men }}{\text { Speci- }}$} & \multicolumn{10}{|c|}{ Ratio of half length to radius vector } & \multicolumn{10}{|c|}{ Thickness of spirotheca (in micron) } & \multirow{2}{*}{$\begin{array}{c}\text { Pl. } 15 \\
\text { Fig. }\end{array}$} \\
\hline & 1 & 2 & 3 & 4 & 5 & 6 & 7 & 8 & 9 & 10 & 1 & 2 & 3 & 4 & 5 & 6 & 7 & 8 & 9 & 10 & \\
\hline 1 & 2.92 & 3.24 & $4 \quad 3.54$ & 3.81 & 3.64 & 3.39 & 3.45 & 3.51 & 3.33 & & 10 & 10 & 12 & 12 & 13 & 13 & 14 & 15 & 17 & & 19 \\
\hline 2 & 1.58 & 2.38 & $8 \quad 3.05$ & 3.94 & 4.38 & 4.79 & 4.42 & 4.39 & 3.87 & & 8 & 8 & 8 & 9 & 9 & 10 & 11 & 16 & 16 & & 21 \\
\hline 4 & & & & & & & & & & & 8 & 9 & 10 & 11 & 11 & 12 & 13 & 14 & 16 & 15 & 23 \\
\hline \multirow{2}{*}{$\begin{array}{c}\text { Speci- } \\
\text { men }\end{array}$} & \multicolumn{14}{|c|}{ Septal count } & & & & & & & \\
\hline & 1 & & 2 & 3 & 4 & & 5 & 6 & 7 & & 8 & 9 & 10 & & & & & & & & \\
\hline 4 & 5 & & 9 & 12 & 14 & & 13 & 14 & 16 & & 14 & $14 ?$ & - & & & & & & & & \\
\hline
\end{tabular}




\section{Pseudodoliolina ozawai minima MIKLUKHo-MAKLAY}

Pl. 15, Figs. 25-30

1957. Pseudodoliolina ozawai minima Miknukнo-MakLaY. pp. 5-6, pl. 1, fig. 5 . 1959. Pseudodoliolina ozawai minima MikLukHo-Maknay in Rauser-Chernoussova and Fursenko. Osnovii Paleontologii, pl. 11, fig. 1.

Material:-Axial sections, GK.D 13916 from Kpp-38, GK.D 13978 from Kpp-51, GK.D 14038 from Kpp-52, GK.D 13375 from Kpp-54, and GK.D 13578 from Kpp-55.

Description:-Because our materials at hand are insufficient in number, the following description is based on a typical mature specimen (GK.D 13578).

Shell subcylindrical and moderate in size, with broadly rounded poles. The axial section of eleven volutions is $3.77 \mathrm{~mm}$ in length and $1.38 \mathrm{~mm}$ in width, with a form ratio of 2.73. The first volution subspherical. From the second volution axis extends polewards moderately rapidly, and shell takes subcylindrical shape from the third volution. Ratios of half length to radius vector of the first to eleventh volutions are $2.43,2.78,3.07,3.29,3.13,3.26,3.25,3.16,3.04,2.90$, and 2.93 , respectively.

Proloculus small and spherical, having an outside diameter of about 105 microns. Shell expands gradually and nearly uniformly except for the first volution which coils tightly. Radius vectors of the first to eleventh volutions are 72 , $98,135,175,235,290,345(?), 415(?), 500,590$ and 645 (?) microns, respectively. Chamber is nearly the same in height in the cylindrical median portion, but increases in height rapidly polewards.

Spirotheca is thin and composed of a tectum and very finely alveolar keriotheca. The latter is, however, hardly observable in inner volutions and is recognized not necessarily in all parts of outer volutions. Thickness of spirotheca in the first to tenth volutions measures $9,10,10,10,10,10,11,11,11$, and 12 microns, respectively.

Parachomata do not appear in the innermost volution. In the second volution they are rudimentary if exist, being widely spaced low deposits on the upper surface of spirotheca. In the following two or three volutions they are low and nearly a half as high as chamber. They are well developed throughout the length of shell in outer volutions where they are high and considerably closely spaced, and more than a half to three-fourths of the height of chamber.

Remarles:-Pseudodoliolina ozawai minima was established by MILUKHoMAKLay based on a single axial section. The Khao Phlong Phrab specimens are also insufficient in number, but they are quite identical with the type specimen in important biocharacters so far observed in axial sections.

Occurrence:-Rare at Kpp-38, -46, -51, -52, -54, and -55. The uppermost part of the $\mathrm{B}_{4}$ to the lower part of the $\mathrm{B}_{6}$ zone.

\section{Pseudodoliolina ozawai ozawai YABE and HANZAWA}

Pl. 15, Figs. 31-32; Pl. 16, Figs. 1-10

1914. Doliolina lepida Deprat. Mém. Serv. Géol. l'Indochine, tome 3, fasc.1, p. 22, pl. 3, figs. 12-14.

1932. Pseudodoliolina ozawai Yabe and Hanzawa. Proc. Imp. Acad. Japan, vol. 3 , no. 2, p. 40-42. 
Table 26. Measurements of Pseudodoliolina ozawai mimima MikLUkнo-MaKLAY (in mm. unless otherwise stated)

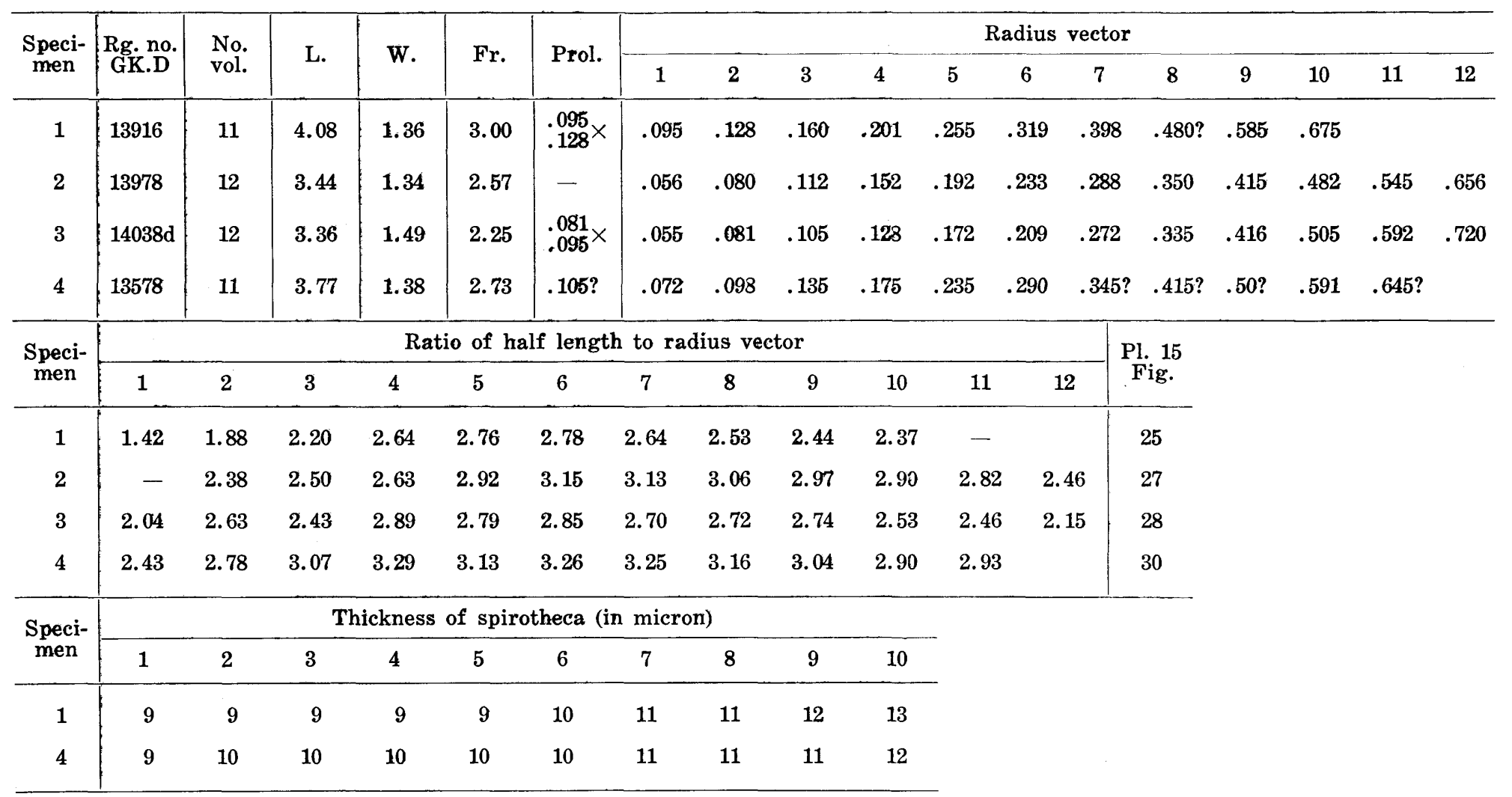


1934. Pseudodoliolina ozawai Chen. Palaeontologia Sinica, Ser. B, vol. 4, fasc. 2, p. 100-101, pl. 16, figs. 3-4.

1936. Pseudodoliolina ozawai Huziмoto. Sci. Rep. Tokyo Bunrika Daigaku, Sec. C, vol. 1, no. 2, p. 108-110, pl. 21, figs. 13-18.

1956. Pseudodoliolina ozawai CHen. Palaeontologia Sinica, N.S., B, no. 6, p. 5354, pl. 4, figs. 12-14.

1956. Pseudodoliolina ozawai Sheng. Acta Palaeont. Sinica, vol. 4, no. 2, p. 218219, pl. 5, figs. 4, 5, 7 (non fig. 6).

1957. Pseudodoliolina ozawai KobaYASHI. Sci. Rep. Tokyo Kyoiku Daigaku, Sec. C, no. 42, p. 298-300, pl. 8, figs. 1-2; pl. 9, figs. 1-4.

1958. Pseudodoliolina ozawai TorIYAma. Mem. Fac. Sci. Kyushu Univ., Ser. D, Geol., vol. 7, p. 213-215, pl. 39, figs. 26-32.

1958. Pseudodoliolina ozawai SAKAGAMI. Jour. Hokkaido Gakugei Univ., vol. 9, no. 2, p. 90-91, pl. 4, fig. 4.

1961. Pseudodoliolina ozawai Nogami. Mem. Coll. Sci. Univ. Kyoto, Ser. B, vol. 28, no. 2, p. 159-163, pl. 1, figs. 1-5.

1961. Pseudodoliolina ozawai ? MoRIKAWA and IsomI. Rep. Geol. Surv. Japan, no. 191, p. 26, pl. 18, figs. 10-12.

Material:-Axial sections, GK.D 13916 from Kpp-38, GK.D 13347 and 14038d from Kpp-52, GK.D 13379 from Kpp-55, GK.D 13505 from Kpp-63, GK.D 13996 from Kpp-73, GK.D 13834 and $13835 \mathrm{~b}$ (more or less oblique) from Kpp-75; sagittal sections, GK.D 13346 and 13347c from Kpp-52, GK.D 13761 from Kpp-70, GK.D 13840c from Kpp-75. Several other thin-sectioned specimens are assigned to this species.

Description:-Shell is subcylindrical and small to moderate in size for the genus. Central one-fourth of shell is cylindrical. Lateral slopes very gently convex and poles broadly rounded. Mature shells of ten to twelve volutions are 3.74 to $4.43 \mathrm{~mm}$ in length and 1.54 to $2.07 \mathrm{~mm}$ in width, with form ratio of 2.08 to 2.68. The first volution subspherical to short subcylindrical, and from the second volution to maturity shell is almost the same in axial profile. Ratios of half length to radius vector for the first to eleventh volutions in three specimens average 2.59, $2.83,3.07,3.10,3.06,3.05,3.06,2.97,2.87,2.77$, and 2.65 , respectively.

Proloculus small and spherical to subspherical, with outside diameter of 111 to 140 microns in spherical form and $80 \times 95$ to $126 \times 170$ microns in subspherical ones, averaging 134 microns in five specimens. Shell coils tightly in inner three to four volutions, and expands almost uniformly in outer volutions. Radius vectors of the first to eleventh volutions in six specimens average 89, 121, 162, 208, 262, $331,413,511,622,733$, and 819 microns, respectively.

Spirotheca thin and its thickness does not exceed 20 microns even at the thickest part. Average thickness of spirotheca for the first to eleventh volutions in five specimens is $10,10,10,11,15,15,15,17,18,19$, and 21 microns, respectively. Spirotheca is apparently composed of a single homogeneous layer in inner four to five volutions, but in outer volutions it consists of a tectum and less dense lower layer, in the latter of which alveolar structure is hardly observable. However, in a limited part of outer two to three volutions very fine alveolar-like structure is faintly observed.

Septa thin and the same in structure as spirotheca, and rather widely spaced. Tips of septa mostly joined with parachomata. Septal counts of the first to tenth volutions in two specimens, 4?,11?, 12?, 14-15, 15-16, 14-18, 16-17, 15-21, $20-23$, and 22 , respecively. 
Table 27. Measurements of Pseudodoliona ozawai ozawai YABE and HANAzAWA (in mm. unless otherwise stated)




Parachomata do not occur in the first one to two volutions. From the second or third volution they are well developed, and low and broad in inner volutions, with about a half of chamber height, but become high and less widely spaced, being about a half to two-thirds as high as chambers. Foramina small and circular in cross section.

Remarks-Pseudodoliolina ozawai YABE and HANZAWA is one of good indicators for the lower Middle Permian and has been described from many localities in Japan, South China and Indochina. The Khao Phlong Phrab specimens are identical with the lectotype specimen from Akasaka in essential diagnostic characters. TORIYAMA (1958) described the present species in detail from the Akiyoshi Limestone Group with which the Khao Phlong Phrab specimens are quite identical, except for that the latter/has a smaller proloculus in general.

CHEN (1956) described P. ozawai from the lower part of the Chinghsichung Limestone of Hunan, South China. His specimens are considerably larger in size and in number of volution than those of the Khao Phlong Phrab specimens. However, one of the topotype specimen (JPF-10316) illustrated by NoGAMI (1961) is nearly the same in dimension with the Khao Phlong Phrab specimens. Therefore, it is assumed that the variation within the species is considerably large in the present species.

Occurrence:-Abundant at Kpp-52; common at Kpp-71 and -75; rare at Kpp$55,-56,-61,-63,-70,-73,-76$, and -80 . The $B_{6}$ and $B_{7}$ zones.

Genus Metadoliolina IsHII and NoGAmI, 1961

Metadoliolina pinguis TORIYAMA and KANMERA, n. sp.

Pl. 16, Figs. 11-15

Material:-Holotype, GK.D 13693 from Kpp-51: Paratypes, axial sections, GK.D 13344 from Kpp-52, GK.D 13430 from Kpp-57, and GK.D 13480 from Kpp-61.

Description:-Shell moderate in size for the genus, and thick melon-shaped, with almost straight axis of coiling, gently convex lateral slopes and broadly rounded poles. Mature shell of eleven to twelve volutions is 2.78 to $3.29 \mathrm{~mm}$ in length and 1.57 to $1.99 \mathrm{~mm}$ in width, having a form ratio of 1.44 to 1.88 . The first volution subspherical to short ellipsoidal. The following one or two volutions short ellipsoidal. From the third or fourth volution to maturity shell is almost the same in axial profile. Ratios of half length to radius vector in the first to eleventh volutions in four specimens average 1.32, 1.54, 1.82, 1.95, 2.00, 2.04, 1.98, $1.93,1.87,1.80$, and 1.84 , respectively.

Proloculus small and spherical to subspherical, with outside diameter of $120 \times 144$ microns in the largest and 72 microns in the smallest. Shell expands slowly in inner two to three volutions. Expansion becomes slightly rapid in the following two to three volutions, and it is almost uniform in outer volutions. Radius vectors of the first to eleventh volutions in four specimens average 74,111 , $151,197,259,332,423,516,620,731$, and 852 microns, respectively.

Spirotheca is thin in inner three to five volutions, consisting of a tectum and less dense lower layer in which no minute structure is observable. In outer volutions spirotheca is relatively thick, and very faint alveolar structure is recognized though it is seen in a limited part. Thickness of spirotheca for the first to tenth volutions in three specimens average $9,10,11,15,14,16,19,17,18$, and 22 microns, respectively. 
Table 28. Measurements of Metadoliolina pinguis TORIYAMA and KANMERA, n. sp. (in mm. unless otherwise stated)

\begin{tabular}{|c|c|c|c|c|c|c|c|c|c|c|c|c|c|c|c|c|c|}
\hline \multirow{2}{*}{$\begin{array}{l}\text { Speci- } \\
\text { men }\end{array}$} & \multirow{2}{*}{$\begin{array}{l}\text { Rg. no. } \\
\text { GK.D }\end{array}$} & \multirow{2}{*}{$\begin{array}{l}\text { No. } \\
\text { vol. }\end{array}$} & \multirow{2}{*}{ L. } & \multirow{2}{*}{ w. } & \multirow{2}{*}{ Fr. } & \multirow{2}{*}{ Prol. } & \multicolumn{11}{|c|}{ Radius vector } \\
\hline & & & & & & & 1 & 2 & 3 & 4 & 5 & 6 & 8 & 9 & 10 & 11 & 12 \\
\hline 1 & 13693 & 12 & 3.29 & 1.99 & 1.65 & $.081 \times$ & .080 & .111 & .159 & .214 & .287 & .367 & .575 & .670 & .792 & .9351 & $1.055 \pm$ \\
\hline 2 & 13430 & 11 & 2.78 & 1.57 & 1.77 & .071 & .066 & .112 & .153 & .193 & .256 & .321 & .490 & .576 & .672 & $.752+$ & \\
\hline 3 & 13480 & 12 & 3.01 & 1.60 & 1.88 & .072 & .055 & .076 & .100 & .135 & .175 & .225 & .345 & .447 & .546 & .665 & .780 \\
\hline 4 & 13344 & 11 & 2.84 & 1.99 & 1.44 & $.120 \times$ & .094 & .144 & .191 & .247 & .319 & .416 & .655 & .785 & .912 & $1.055 \pm$ & \\
\hline \multirow{2}{*}{$\begin{array}{c}\text { Speci- } \\
\text { men }\end{array}$} & \multicolumn{12}{|c|}{ Ratio of half length to radius vector } & \multirow{2}{*}{$\begin{array}{l}\text { Pl. } 16 \\
\text { Fig. }\end{array}$} & & & & \\
\hline & 1 & 2 & 3 & 4 & 5 & 6 & 7 & 8 & 9 & 10 & 11 & 12 & & & & & \\
\hline 1 & 1.38 & 1.71 & 1.81 & 1.93 & 1.98 & 1.96 & 1.86 & 1.81 & 1.79 & 1.72 & 1.64 & 1.61 & 11 & & & & \\
\hline 2 & 1.46 & 1.56 & 1.58 & 1.82 & 1.88 & 1.95 & 2.00 & 1.90 & 1.95 & 1.90 & 1.81 & & 13 & & & & \\
\hline 3 & 1.27 & 1.60 & 2.55 & 2.48 & 2.57 & 2.56 & 2.45 & 2.38 & 2.16 & 2.06 & 1.97 & 1.97 & 14 & & & & \\
\hline 4 & 1.18 & 1.28 & 1.33 & 1.55 & 1.56 & 1.69 & 1.61 & 1.61 & 1.57 & 1.53 & & & 15 & & & & \\
\hline \multirow{2}{*}{$\begin{array}{c}\text { Speci- } \\
\text { men }\end{array}$} & \multicolumn{11}{|c|}{ Thickness of spirotheca (in micron) } & & & & & & \\
\hline & 1 & 2 & 3 & 4 & 5 & 6 & 7 & 8 & 9 & 10 & 11 & & & & & & \\
\hline 1 & 9 & 10 & 12 & 17 & 20 & 20 & 25 & 20 & 20 & 24 & 23 & & & & & & \\
\hline 2 & - & - & 10 & - & 10 & 13 & 14 & 15 & 17 & 20 & & & & & & & \\
\hline 4 & 9 & 10 & 12 & 12 & 13 & 15 & 17 & 17 & 17 & 21 & & & & & & & \\
\hline
\end{tabular}


Parachomata do not occur in inner two to three volutions, and they are very few if exist in the following one to two volutions. In outer volutions they are well developed, being more or less widely spaced and about a half as high as chambers in the fourth or fifth to the ninth or tenth volutions. In outermost two volutions parachomata high and narrow, having two-thirds of chamber height.

Remarks:-Metadoliolina pinguis n. sp. is somewhat similar to Pseudodoliolina chinghaiensis described by SHENG (1958) from Chinghai, Northwest China, from which the former is distinguished by having thicker spirotheca and a different spirothecal structure. The small size of shell and primitive development of parachomata suggests that the present species is in an earlier stage of phylogenetical development from primitive representatives of Pseudodoliolina to Metadoliolina. In the Khao Phlong Phrab fauna Metadoliolina pinguis n. sp. and Pseudodoliolina saraburiensis n. sp. are closely related with each other, and it is suggested that the former is derived from the latter.

Occurrence:-Common at Kpp-52; rare at Kpp-51, -54, -57, -61 and -75. The $B_{6}$ and the lower part of the $B_{7}$ zone.

Family Neoschwagerinidae DUNBAR, 1948

Subfamily Sumatrininae SILvestri, 1933, emend. KANMERA, 1957

Genus Cancellina HAYDEN, 1909

Cancellina phlongphrabensis TORIYAMA and KanMERA, n. sp. Pl. 16, Figs. 16-25

Material:-Holotype, GK.D 13728 from Kpp-34: Paratypes, axial sections, GK.D 13282 from Kpp-27b, GK.D 13065, 13071b, 13073, and 13133 from Kpp-39; sagittal sections, GK.D 13071c from Kpp-39. A number of other sectioned specimens are referable to this species.

Description:- Shell small and thickly fusiform, with a straight axis of coiling, gently convex lateral slopes, and broadly rounded poles. The holotype specimen of seven volutions attains a length of $2.19 \mathrm{~mm}$ and a width of $1.41 \mathrm{~mm}$, giving a form ratio of 1.55 .

Shell coils tightly in the first one and a half volutions and expands moderately rapidly in outer volutions. Proloculus is small and nearly spherical, but it is not so small for the size of shell. Outside diameter 110 to 151 microns, averaging 128 microns in six specimens. Microspheric form (GK.D 13133, pl. 16, fig. 16) present, having an outside diameter of 62 microns. In this form shell coils tightly in the first two volutions whose axis is perpendicular to that of outer volutions. Average radius vectors of the first to eighth volutions in six specimens are 106,152, 212, 298, $402,532,663$, and 780 microns, respectively. Height of chamber is nearly the same throughout the length of shell except in polar regions.

Spirotheca thin, composed of a tectum and a very finely alveolar keriotheca. Its thickness in the holotype specimen is $9,10,12,14,14$, and 19 microns, respectively in the first to sixth volutions. In the paratype specimens they are 8-11, 8-11, 8-13, 9-17, 13-18, 15-19, and 16-20 microns in the first to seventh volutions.

Primary transverse septula absent or very poorly developed if present in the first one to two volutions, but well developed throughout in outer volutions. Neither secondary transverse nor axial septula present.

Parachomata is not developed or very poorly developed in the inner two to 
Table 29. Measurements of Cancellina phlongphrabensis TORIYAMA and KANMERA, n. sp. (in mm. unless otherwise stated)

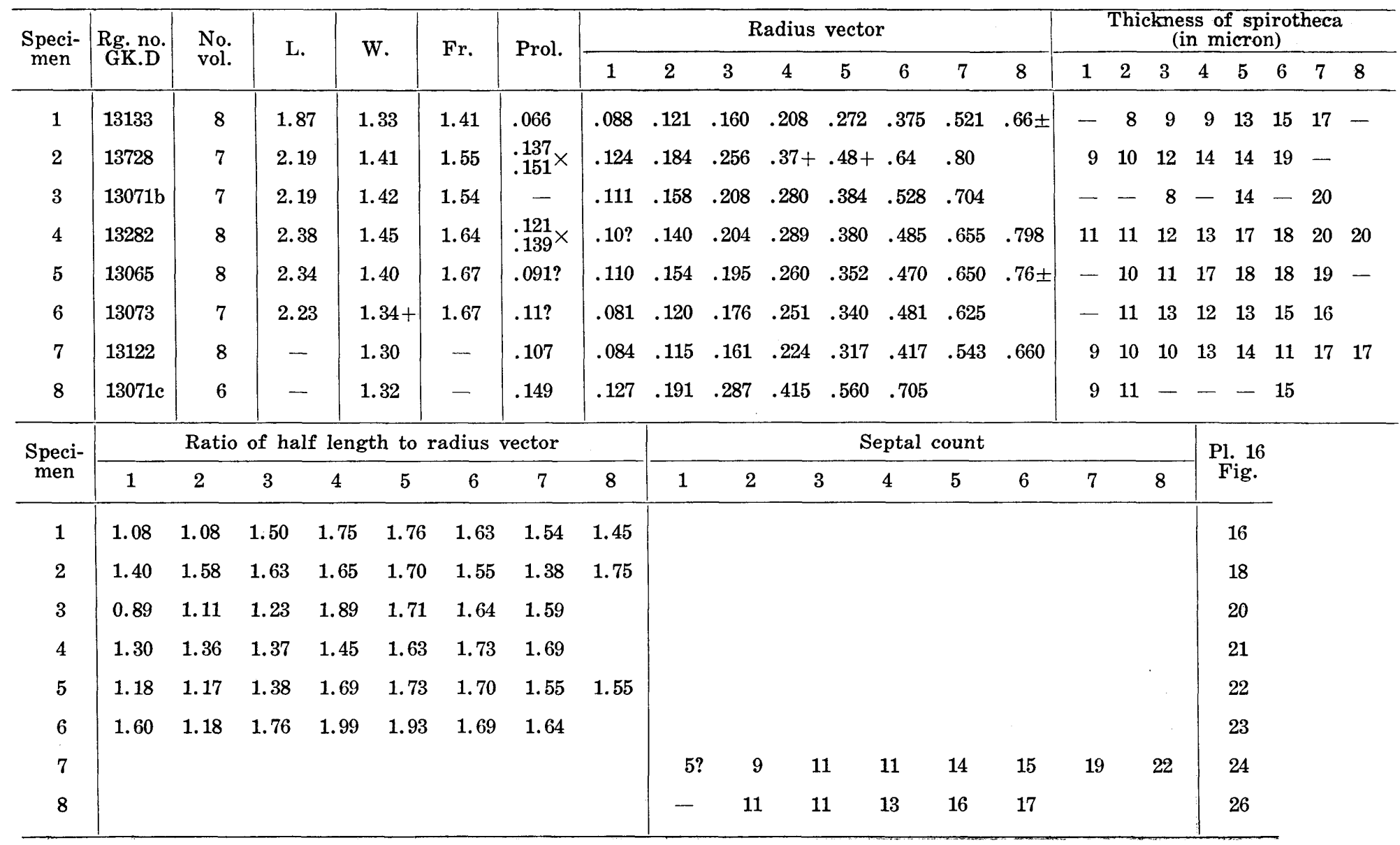


three volutions, and becomes more or less distinct in outer volutions where they are low and broad deposits on the upper surface of spirotheca. They are less than a half as high as chamber, and in contact with the lower ends of primary transverse septula. Foramina small and circular in cross section.

Remarks:-The present new species closely resembles an unnamed new subspecies of Cancellina nipponica illustrated by KANMERA (1957) from the lower part of the C. nipponica zone of the Akasaka Limestone. The illustrated axial section (pl. 19, fig. 6) of six volutions is $1.63 \mathrm{~mm}$ in length and $1.16 \mathrm{~mm}$ in width, with a form ratio of 1.41. Poor development of transverse septula, absence of axial septula, and small size of shell suggest that $C$. phlongphrabensis and C. nipponica subspecies $A$ are closely allied if not exactly conspecific. They are considered to be nearly the same position in the phylogenetic development.

The present new species also resembles Cancellina parva (CoLANI), but is distinguished from the latter in having more numerous volutions and a smaller proloculus. The latter has poorly developed axial septula in a part of outer volutions. The present new species is also similar to Cancellina bukowskii KocHANSKYDEVIDÉ in shape and dimension of shell, but is clearly distinguished from the latter by the absence of axial and secondary transverse septula in the former.

The absence of axial septula and poor development of primary transverse septula and parachomata in inner volutions suggest that the present new species is in an earlier stage of phylogenetic development of the genus Cancellina.

Occurrence:-Kpp-27b, -34, -35, -36, -38, and -39. The $\mathrm{B}_{4}$ zone.

Cancellina sp. A

Pl. 17, Figs. 1-4

Material:-Axial sections, GK.D 13150 from Kpp-37, GK.D 13628 from Kpp46, tangential section, GK.D 13651 from Kpp-47.

Description:-Shell is small and typical fusiform, with straight to slightly shifting axis of coiling, convex lateral slopes and broadly pointed poles. Mature shell of 6 to 8 volutions 2.44 to $2.84 \mathrm{~mm}$ in length and 1.02 to $1.22 \mathrm{~mm}$ in width, giving a form ratio of 2.33 to 2.46. Inner one or two volutions elliptical or short fusiform, and the succeeding volutions nearly the same in axial profile. Ratios of half length to radius vector of the first to eighth volutions in three specimens average $1.64,1.84,2.29,2.61,2.50,2.44,2.50$, and 2.43 , respectively.

Proloculus small and spherical to subspherical, with outside diameter $80 \times 123$ microns in one specimen and about 160 microns in the other one. Shell coils rather tightly in the first volution, and expands slowly and uniformly in outer volutions. Average radius vectors of the first to eighth volutions in three specimens 80,117 , $156,213,298,384,424$, and 548 microns respectively.

Spirotheca very thin, consisting of a tectum and very fine alveolar keriotheca, but in some specimen, especially in inner volutions, spirotheca seems to be composed of a single compact layer. Thickness of spirotheca measured in two specimens $8,8,9,9-11,11-13,14,14$, and 21 microns in the first to eighth volutions.

Development of axial septula not known, because of absence of sagittal section. Primary transverse septula present throughout length of shell, though very incipient in inner two volutions. No secondary transverse septula present.

Parachomata rather low and broad, connecting with lower tips of primary transverse septula. 
Table 30. Measurements of Cancellina sp. A (in mm. unless otherwise stated)

\begin{tabular}{|c|c|c|c|c|c|c|c|c|c|c|c|c|c|c|c|c|c|c|c|c|c|c|}
\hline \multirow{2}{*}{$\begin{array}{c}\text { Speci- } \\
\text { men }\end{array}$} & \multirow{2}{*}{$\begin{array}{c}\text { Rg. no. } \\
\text { GK.D }\end{array}$} & \multirow{2}{*}{$\begin{array}{l}\text { No. } \\
\text { vol. }\end{array}$} & \multirow{2}{*}{ L. } & \multirow{2}{*}{$\mathrm{w}$. } & \multirow{2}{*}{ Fr. } & \multirow{2}{*}{ Prol. } & \multicolumn{8}{|c|}{ Radius vector } & \multicolumn{8}{|c|}{$\begin{array}{l}\text { Thickness of spirotheca } \\
\text { (in micron) }\end{array}$} \\
\hline & & & & & & & 1 & 2 & 3 & 4 & 5 & 6 & 7 & 8 & 1 & 2 & 3 & 4 & 5 & 6 & 7 & 8 \\
\hline 1 & 13628 & 6 & 2.60 & 1.06 & 2.46 & $.162 ?$ & .111 & .168 & .224 & .295 & .385 & .495 & & & 8 & - & 9 & 9 & 13 & 14 & & \\
\hline 2 & $13150 \mathrm{~d}$ & 8 & 2.84 & 1.22 & 2.33 & $.080 \times$ & .080 & .112 & .145 & .200 & .288 & .376 & .480 & .600 & - & 8 & 9 & 11 & 11 & - & 14 & 21 \\
\hline 3 & 13651 & 8 & 2.44 & 1.02 & 2.39 & - & $.05 ?$ & .072 & .100 & .145 & .220 & .280 & .368 & .496 & - & - & - & - & - & - & - & - \\
\hline \multirow{2}{*}{$\begin{array}{l}\text { Speci- } \\
\text { men }\end{array}$} & \multicolumn{8}{|c|}{ Ratio of half length to radius vector } & \multirow{2}{*}{\multicolumn{2}{|c|}{$\begin{array}{l}\text { Pl. } 17 \\
\text { Fig. }\end{array}$}} & & & & & & & & & & & & \\
\hline & 1 & 2 & 3 & 4 & 5 & 6 & 7 & 8 & & & & & & & & & & & & & & \\
\hline 1 & 1.73 & 2.00 & 2.36 & 2.66 & 2.54 & 2.36 & & & & 1 & & & & & & & & & & & & \\
\hline 2 & 1.60 & 1.57 & 2.21 & 2.56 & 2.50 & 2.39 & 2.64 & 2.51 & & 3 & & & & & & & & & & & & \\
\hline 3 & 1.60 & 1.94 & 2.30 & 2.62 & 2.45 & 2.57 & 2.47 & 2.34 & & 4 & & & & & & & & & & & & \\
\hline
\end{tabular}


Remarks:-Although enough information for the specific characteristics of this species has not been available due to insufficiency of the present material, the features of the present specimens are somewhat similar to those of Cancellina phlongphrabensis $\mathrm{n}$. $\mathrm{sp}$. in the size of shell, size of proloculus and absence of secondary transverse septula, but differs from the latter in having more slender shell and somewhat well developed primary transverse septula and parachomata.

It is assumed that $C$. sp. $A$ is intermediate in important shell characteristics between $C$. phlongphrabensis n. sp. and C. tenuitesta KANMERA. It is therefore suggested that these three species constitute an earlier stage of phylogenetic lineage in the genus Cancellina.

Occurrence:-Rare at Kpp-37, -46 , and -47 . The upper part of the $B_{4}$ to the $\mathrm{B}_{5}$ zone.

\section{Cancellina tenuitesta KANMERA}

Pl. 17, Figs. 5-13

1963. Cancellina tenuitesta Kanmera. Mem. Fac. Sci. Kyushu Univ. Ser. D, Geol., vol. 14, no. 2, p.114-115, pl.13, figs. 7-13; pl. 19, figs. 16-17.

Holotype:-Axial section, GK.D 12292 illustrated by KANMERA as plate 13, fig. 7.

Material:-Axial sections, GK.D 13680a and 13678 from Kpp-51; GK.D 14097 from Kpp-53; GK.D 13574b from Kpp-55, and GK.D 13400 and 13428 from Kpp-57; tangential sections, GK.D 13656b from Kpp-50 and GK.D 13403 from Kpp-57; sagittal section, GK.D 13653 from Kpp-50.

Descriptive remarks:-Cancellina tenuitesta was described in detail and well illustrated by KANMERA, although he did not give the statistical data on the Kozaki specimens. It is, therefore, unnecessary to add further description except for giving the following comments and statistical data on the Khao Phlong Phrab specimens.

The Khao Phlong Phrab specimens are slightly more elongate in shell form, having a little larger form ratio, and slightly thicker spirotheca, especially in the inner volutions. Other important characteristics well agree with in the Khao Phlong Phrab and the Kozaki specimens. A specimen (GK.D 13656b) identified to the present species with a query has very rudimentary secondary transverse septula in few chamberlets of the outermost volution.

Occurrence:-Common at Kpp-50 and -51; rare at Kpp-52, -53, -55 and -57. The uppermost part of $B_{5}$ zone and the $B_{6}$ zones.

\section{Cancellina neoschwagerinoides (DEPRAT)}

Pl. 17, Figs. 14-23

1913. Doliolina neoschwagerinoides Deprat. Mém. Serv. Géol. l'Indochine, tome 2, fasc. 1, p. 52-53, pl. 10, figs. 1-7.

1924. Doliolina efr. neoschwagerinoides Colani. Mém. Serv. Géol. l'Indochine, tome 11, fasc. 1 , pp. 115, pl. 20, fig. 4.

1963. Cancellina neoschwagerinoides SHENG. Palaeont. Sinica, N.S., B, no. 10, p. 232, pl. 34, figs. 7-8, 10-12.

Lectotype:-Doliolina neoschwagerinoides DEPRAT, 1913, pl. X, fig. 2 is designated here as the lectotype of the species. 
Table 31. Measurements of Cancellina tenuitesta KANMERA (in mm. unless otherwise stated)

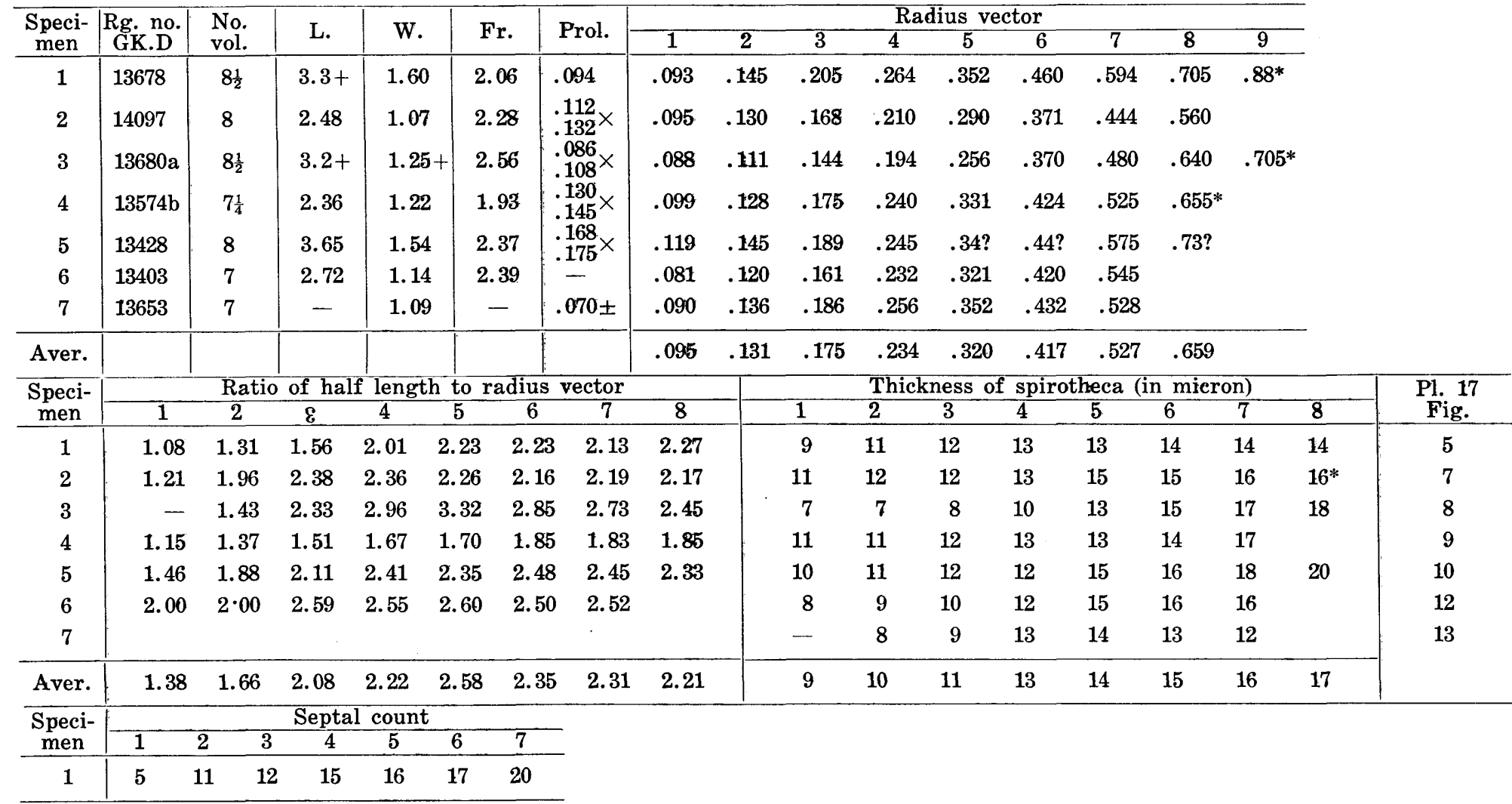

* measured a half volution earlier than others in the same column. 
Table 32. Measurements of Cancellina neoschwagerinoides (DEPRAT) (in mm. unless otherwise stated)

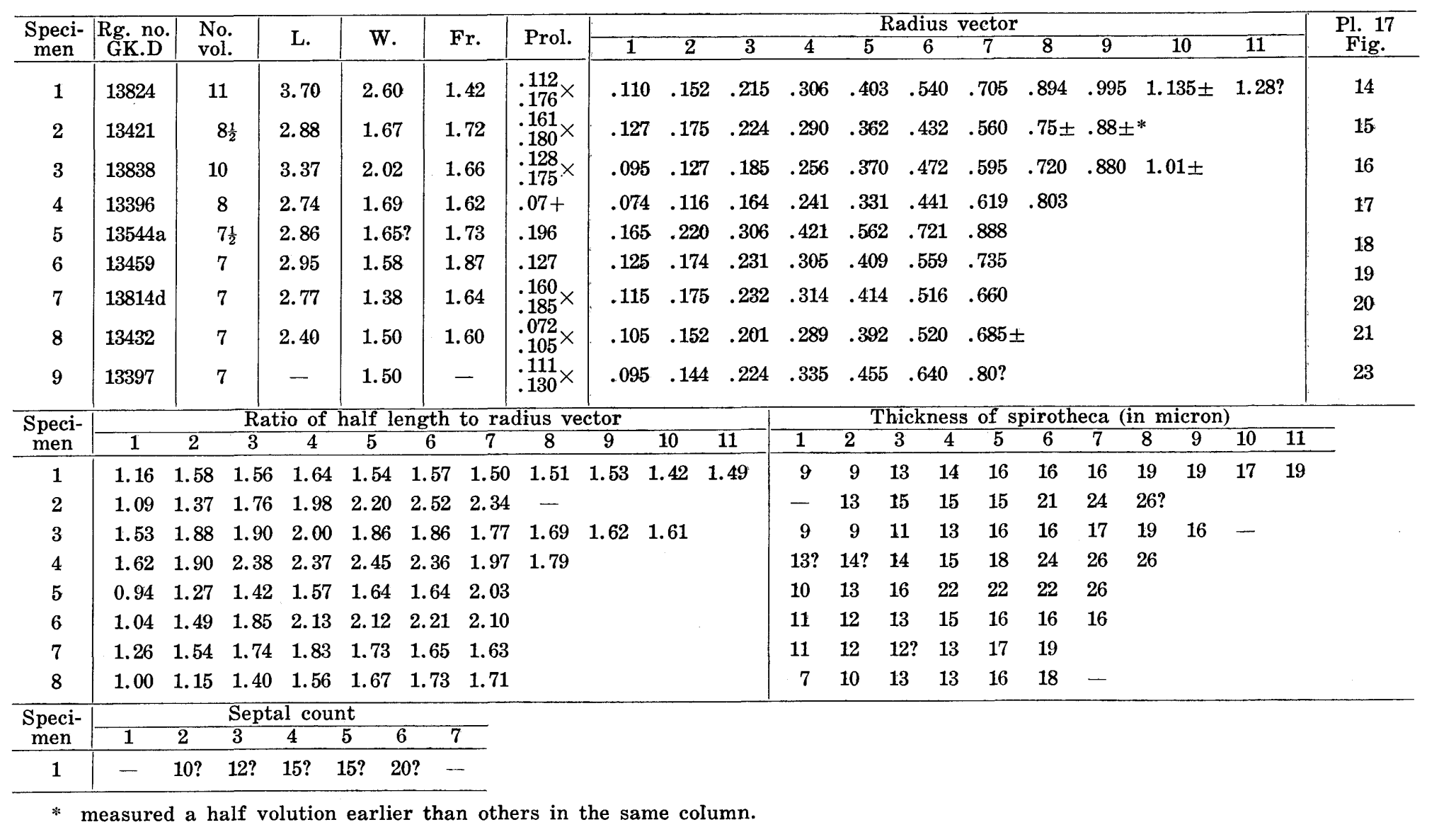


Material:-Axial sections, GK.D 13421, 13426, and 13432 from Kpp-57, GK.D 13459 from Kpp-60, GK.D 13838 from Kpp-75, GK.D 13811a, 13811b, 13814, and 13824 from Kpp-76; sagittal sections, GK.D 13397 from Kpp-57, GK.D 13811c from Kpp-76. Many other sectioned specimens are referred to this species.

Description:-Shell small to moderate in size, short fusiform, with gently convex lateral slopes and broadly rounded poles. Volution usually 7 to 9,11 at maximum. Length of shell ranging from 2.19 to $3.76 \mathrm{~mm}$ and width from 1.36 to $2.06 \mathrm{~mm}$, with a form ratio of 1.36 to 1.72 . The first volution subspherical, the second volution short fusiform, and outer volutions assume fusiform. Ratios of half length to radius vector of the first to eighth volutions in eight specimens average $1.21,1.52,1.75,1.89,1.90,1.94,1.88$, and 1.88 , respectively.

Proloculus minute and spherical to subspherical, having outside diameter of 172 to 196 microns, with an average of 139 microns in nine specimens. Shell coils rather tightly in the first two volutions, and expands slowly and uniformly from the third volution to maturity. Average radius vectors of the first to eighth volutions in nine specimens are 112, 159, 220, 306, 411, 538, 694, and 792 microns, respectively. Chamber is nearly the same in height throughout the length of shell except for polar regions where it increases height slightly.

Spirotheca is very thin and composed of a tectum and a very fine alveolar keriotheca. Minute alveolar structure of keriotheca is often obscure probably because of secondary mineralization. Thickness of spirotheca measured at the thinnest part averages $10,12,13,15,17,19,21$, and 23 microns, respectively in the first to eighth volutions in eight specimens.

Septa thin and slender, being the same as spirotheca in structure. Septal count of the second to sixth volutions in one of saggital section (GK.D 13397) is 10 ?, 12, 15, 15, and 20, respectively. Axial septula appear between two adjacent septa in a part of outer two volutions. Primary transverse septula also very thin and slender, their lower ends joined with tops of parachomata. Secondary transverse septula not present in most volutions, but one thin and short secondary transverse septulum appears in a limited part of the last one to two volutions of fully grown individuals.

Remarks:-The Khao Phlong Phrab specimens well agree in important characteristics with those described by ShENG (1963) from the lower part the Maokou Limestone at near Zisongzheng of Wangmo, Kueichow Province, South China, especially in the presence of secondary transverse septula though they are very primitive and only observable in a part of outer volutions. In this respect the Khao Phlong Phrab and Zisongzheng specimens differ from the Indochinese specimens of DEPRAT.

Occurrence:-Common at Kpp-57; rare at Kpp-60, $-61,-63,-75$, and -76 . The upper part of the $B_{6}$ zone to be the lower part of the $B_{7}$ zone.

\section{Genus Presumatrina ToumanskaYA, 1950}

Presumatrina schellwieni (DEPRAT)

Pl. 17, Figs. 24-33; Pl. 18, Figs. 1-5

1913. Doliolina schellwieni Deprat. Mém. Serv. Géol. l'Indochine, tome 2, fasc. 2, p. 51-52, pl. 8, figs. 4-9. 
Table 33. Measurements of Presumatrina schellwieni (DEPRAT) (in mm. unless otherwise stated)

\begin{tabular}{|c|c|c|c|c|c|c|c|c|c|c|c|c|c|c|c|c|c|c|}
\hline \multirow{2}{*}{$\begin{array}{c}\text { Speci- } \\
\text { men }\end{array}$} & \multirow{2}{*}{$\begin{array}{l}\text { Rg. no. } \\
\text { GK.D. }\end{array}$} & \multirow{2}{*}{$\begin{array}{l}\text { No. } \\
\text { vol. }\end{array}$} & \multirow{2}{*}{ L. } & \multirow{2}{*}{ W. } & \multirow{2}{*}{\multicolumn{2}{|c|}{ Fr. }} & \multirow{2}{*}{ Prol. } & \multicolumn{9}{|c|}{ Radius vector } & \multirow{2}{*}{$\begin{array}{l}\text { Pl. } 17 \\
\text { Fig. }\end{array}$} & \multirow{2}{*}{$\begin{array}{l}\text { Pl. } 18 \\
\text { Fig. }\end{array}$} \\
\hline & & & & & & & & 1 & 2 & \multirow{2}{*}{$\begin{array}{c}0 \\
.301\end{array}$} & 4 & \multirow{2}{*}{$\begin{array}{c}5 \\
.549\end{array}$} & 6 & 7 & 8 & 9 & & \\
\hline & 13540 & 7 & 2.94 & 1.66 & & 1.77 & .192 & .160 & .221 & & .410 & & .720 & \multicolumn{3}{|l|}{$.88 \pm$} & \multirow{2}{*}{$\begin{array}{l}24 \\
25\end{array}$} & \\
\hline 2 & $13535 \mathrm{a}$ & 7 & 2.88 & 1.39 & & 2.07 & $.163 \times$ & . 128 & .175 & .241 & .305 & .401 & .542 & \multicolumn{3}{|l|}{.672} & & \\
\hline 3 & $13811 b$ & $7 \frac{1}{2}$ & 2.86 & 1.36 & & 2.10 & \multirow{2}{*}{$\begin{array}{l}.134 \times \\
.180 \times \\
.15 ?\end{array}$} & .095 & .128 & .184 & .250 & .336 & .448 & .560 & \multicolumn{2}{|c|}{$.705 ?^{*}$} & 27 & \\
\hline 4 & $13811 \mathrm{a}$ & 8 & 2.76 & 1.50 & & 1.84 & & .099 & .132 & 177 & .265 & .369 & .481 & .582 & \multicolumn{2}{|l|}{.698} & 28 & \\
\hline 5 & 13533 & 7 & 3.25 & 1.23 & & 2.64 & .140 & .105 & .168 & .205 & .280 & .375 & .480 & .605 & & 29 & \\
\hline 6 & 13823 & 8 & 3.47 & 1.42 & & 2.44 & \multirow{3}{*}{$\begin{array}{l}.11 ? \\
.144 \\
.199 \\
.192\end{array}$} & 107 & .161 & .220 & .295 & .391 & .504 & $.625 ?$ & \multicolumn{2}{|l|}{$.75 \pm$} & 30 & \\
\hline 7 & $13812 \mathrm{a}$ & $8 \frac{1}{2}$ & 3.09 & 1.62 & & 1.90 & & .111 & .160 & .211 & .290 & .352 & .496 & .615 & .760 & $.850^{*}$ & 31 & \\
\hline 8 & $14046 \mathrm{~b}$ & 7 & $3.5 \pm$ & 1.31 & & 2.67 & & .134 & .174 & .231 & .303 & .410 & .500 & .623 & & & & 1 \\
\hline 9 & 13512 & 8 & $3.25+$ & 1.31 & & 2.48 & $.10 ?$ & .082 & .115 & .158 & .223 & .288 & .385 & .480 & .561 & & & 2 \\
\hline 10 & 13808 & 8 & 3.17 & 1.38 & & 2.30 & $.14 ?$ & .110 & .152 & .209 & .299 & .400 & .520 & .625 & $.72 ?$ & & & 3 \\
\hline 11 & $13481 b$ & 8 & 3.70 & 1.70 & & 2.18 & $.10 ?$ & .095 & .144 & .205 & .272 & .351 & .450 & .535 & .665 & & & 4 \\
\hline 12 & $13812 b$ & 8 & - & 1.87 & & - & $.185 \times$ & .120 & .175 & .272 & .370 & .495 & .648 & .815 & .960 & & 32 & \\
\hline 13 & 13811c & 9 & - & $1.68^{\circ}$ & & - & $.16 ?$ & . 125 & . 185 & .254 & . 321 & .409 & . 504 & .623 & .734 & $.88 \pm$ & 33 & \\
\hline 14 & $14046 \mathrm{a}$ & $7 \frac{1}{2}$ & - & 1.73 & & - & $.219 \times 1$ & .159 & .219 & .278 & . 366 & .511 & .639 & .798 & $.930 *$ & & & 5 \\
\hline $\begin{array}{l}\text { Speci- } \\
\text { men }\end{array}$ & & Rati & of half & length & $\mathrm{h}$ to $\mathrm{r}$ & radius & vector & & & & Thickn & ess of & spirot & eca (in & micro & & & \\
\hline men & 1 & 2 & 3 & 4 & 5 & 6 & 7 & 8 & 1 & 2 & 3 & 4 & 5 & 6 & 7 & 8 & 9 & \\
\hline $\begin{array}{l}1 \\
2\end{array}$ & 0.94 & 1.32 & 1.43 & .63 & 1.80 & 1.67 & 1.67 & & 14 & 15 & 16 & 16 & 18 & 18 & 79 & & & \\
\hline 3 & $\begin{array}{l}1.84 \\
1.84\end{array}$ & $\begin{array}{l}2.54 \\
2.50\end{array}$ & $\begin{array}{l}1.94 \\
2.61\end{array}$ & $\begin{array}{l}.05 \\
.75\end{array}$ & $\begin{array}{l}1.96 \\
2.62\end{array}$ & $\begin{array}{l}2.00 \\
2.35\end{array}$ & $\begin{array}{l}2.07 \\
2.20\end{array}$ & - & 12 & 11 & 13 & $\begin{array}{l}12 \\
13\end{array}$ & $\begin{array}{l}13 \\
17\end{array}$ & $\begin{array}{l}13 \\
18\end{array}$ & 18 & - & & \\
\hline 4 & 1.52 & 2.23 & 2.54 & .42 & 2.38 & 2.31 & 2.23 & - & 14 & 11 & 13 & 14 & 13 & 17 & 17 & $16 ?$ & & \\
\hline $\begin{array}{l}5 \\
6\end{array}$ & 1.57 & $\begin{array}{l}1.90 \\
1.59\end{array}$ & $\begin{array}{l}2.44 \\
1.68\end{array}$ & .63 & $\begin{array}{l}2.73 \\
2.73\end{array}$ & $\begin{array}{l}2.70 \\
2.25\end{array}$ & $\begin{array}{l}2.70 \\
2.30\end{array}$ & 2.24 & 14 & $\begin{array}{l}15 \\
10\end{array}$ & $\begin{array}{l}17 \\
13\end{array}$ & 18 & $\begin{array}{l}18 \\
18\end{array}$ & 18 & $\begin{array}{l}17 \\
19\end{array}$ & 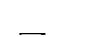 & & \\
\hline 7 & 1.58 & 2.09 & 2.21 & .16 & 2.32 & 2.00 & 2.07 & 2.01 & 9 & 9 & 10 & 15 & 14 & 14 & 16 & 18 & $19^{* *}$ & \\
\hline 8 & 1.78 & 2.86 & 3.58 & 3.36 & 3.17 & 3.07 & 2.82 & & 11 & 12 & 14 & 15 & 17 & 18 & 20 & & & \\
\hline $\begin{array}{r}9 \\
10\end{array}$ & 1.17 & 2.09 & 2.44 & 2.57 & 2.95 & 2.87 & 2.83 & 2.71 & 10 & 129 & 11 & 11 & 13 & 16 & 16 & 17 & & \\
\hline $\begin{array}{l}10 \\
11\end{array}$ & $\begin{array}{l}1.89 \\
1.84\end{array}$ & $\begin{array}{l}2.07 \\
1.99\end{array}$ & 2.21 & 2.24 & 2.25 & 2.22 & 2.23 & 2.24 & 12 & 13 ? & 12 & 13 & 15 & 14 & 16 & 16 & & \\
\hline 12 & & & & & & & & & & 12 & 15 & 16 & 18 & 17 & 20 & 21 & & \\
\hline Speci- & & & Sept & 1 coun & & & & & & & & & & & & & & \\
\hline men & 1 & 3 & 4 & 6 & 7 & 8 & 10 & & & & & & & & & & & \\
\hline 12 & 7 & 16 & 22 & - & - & 一 & & & & red a & half & olutic & earl & tha & ther & in $t$ ] & same $c$ & $\mathrm{nn}$. \\
\hline
\end{tabular}


1957. Praesumatrina cfr. schellwieni MIKLukнo-MAKLAY. Uchenye Zapiski Lgu, 225, p. 140, pl. 10, fig. 3 .

Material:-Axial sections, GK.D 13481 from Kpp-61, GK.D 13512 from Kpp69, GK.D 13532, 13533, 13535, 13540, and 13544a from Kpp-71, GK.D 13808 from Kpp-75, GK.D 13811b, 13812a, 13814a, and 13823 from Kpp-76, GK.D 14046b from Kpp-82; sagittal sections, GK.D 13544b from Kpp-71, 13812b and 13811c from Kpp-76, GK.D 14046a from Kpp-82. Many other sectioned specimens are referred to this species.

Description:-Shell small and typical fusiform, with a straight axis of coiling, gently convex lateral slopes and broadly rounded poles. Mature shell of 7 to $8 \frac{1}{2}$ volutions is 2.50 to $3.70 \mathrm{~mm}$ in length and 1.23 to $1.87 \mathrm{~mm}$ in width, with a form ratio of 1.77 to 2.67 , averaging 2.20 in thirteen specimens. The first volution is nearly spherical, followed by one to two tightly coiled volutions with a short ellipsoidal axial profile. Outer volutions uniformly expand, assuming fusiform shell. Ratios of half length to radius vector of the first to eighth volutions in eleven specimens are $1.36,2.03,2.30,2.37,2.43,2.33,2.34$, and 2.32 , respectively.

Proloculus small and spherical to subspherical, with outside diameter of 100 to 250 microns, averaging 163 microns in fourteen specimens. Shell expands very slowly in the first three volutions and less slowly and uniformly in outer volutions. Average radius vectors of the first to eighth volutions in seventeen specimens are $116,165,225,304,403,523,646$, and 812 microns, respectively. Chambers nearly the same in height throughout the length of shell except for polar regions where they increase in height slightly.

Spirotheca thin, consisting of a tectum and a very finely alveolar keriotheca. Alveolar structure of the latter is not necessarily clear throughout all the volutions, but obscure in some parts of shell. Thicknesses of spirotheca measured at the thinnest part between two adjacent primary transverse septula are 11, 12, 13, $14,16,16,17$, and 18 microns, respectively in the first to eighth volutions of twelve specimens.

Septa thin and composed of downward extension of keriotheca, tips of which are consolidated assuming club shape, although they are not so conspicuous as in species of Afghanella and Sumatrina. Axial septula not present in inner few volutions, and appear at the fourth or fifth volution, although they are very rare. In outer three volutions one axial septulum occurs between two adjacent septa. Primary transverse septula well developed from the first volution. Secondary transverse septula not present, except for a very limited part of outer volutions of some specimens. When exist they are very short and rudimentary, being only a downward swell of keriotheca.

Parachomata also well developed immediately beneath primary transverse septula. They are narrow and about a half as high as chamber.

Remarks:-Compared with the DEPRAT's specimens from Minh-cam of Annam, the Khao Phlong Phrab specimens are slightly larger in size of shell, but diagnostic characteristics are well observed in the latter. As discussed in detail by KANMERA (1957) and TORIYAMA (1958), "Yabeina schellwieni" and "Cancellina schellwieni" described by OzAWA respectively from the Akiyoshi Limestone (1925) and the Akasaka Limestone (1927) are not assignable to Cancellina but referred to Afghanella ozawai HANZAWA.

CHEN (1934) described the present species under the genus Cancellina from the Chihsia Limestone found in Wushih, Kueichih of Anhui Province, South China. 
His specimens are more or less larger in size of shell and numbers of volutions than those of the Annam specimens. It is possible that the DEPRAT's specimens are not fully grown individuals.

Occurrence:-Abundant at $\mathrm{Kpp}-76$; common at $\mathrm{Kpp}-71$; rare at $\mathrm{Kpp}-61,-69$, $-73,-75$, and -82 . The $\mathrm{B}_{7}$ zone.

\section{Presumatrina cfr. grandis LEVEN}

Pl. 18, Figs. 6-15

1967. Praesumatrina grandis Leven. Acad. Sci. USSR, Geol. Inst. Transact. 167 , p. 197 , pl. 36 , figs. 1,3 .

Material:-Axial sections, GK.D 13372 from Kpp-53, 13542a from Kpp-71, GK.D 13994b and GK.D 14110 from Kpp-73, and GK.D 13835a and 13840b from Kpp-75.

Description:-Shell of 7 to 9 volutions is moderate in size and thick fusiform, with straight axis of coiling, convex lateral slopes and broadly rounded poles. Axial length ranges from 2.46 to $3.28 \mathrm{~mm}$ and median width from 1.50 to $1.92 \mathrm{~mm}$, with a form, ratio of 1.35 to 2.00 .

Shell coils considerably tightly in the first one to two volutions where it takes nearly spherical to subspherical shape. From the second or third volution shell expands almost uniformly. Ratios of half length to radius vector of the first to eighth volutions average $1.39,1.63,1.72,1.78,1.86,1.71,1.62$, and 1.59 , respectively in seven specimens.

Proloculus almost spherical to subspherical and large for the size of shell. Outside diameter considerably varies, ranging from $121 \times 135$ to $288 \times 305$ microns. Radius vectors of the first to eighth volutions in eight specimens average $131,186,259,347,455,586,691$, and 807 microns, respectively. Height of chamber almost the same throughout the length of shell except for polar regions where it becomes slightly higher.

Spirotheca thin and composed of a tectum and a keriotheca. In the latter very fine alveolar structure is partly observable. Average thickness of spirotheca measured at the median portion of shell is $11,12,13,14,15,16,17$, and 17 microns, respectively in the first to eighth volutions in eight specimens.

Characters of septa and axial septula are unknown due to the absence of sagittal section in the present material. Primary transverse septula well developed from the first volution to maturity. Secondary transverse septula not present, but there are faint indication of swelling from the lower surface of spirotheca between two adjacent primary transverse septula in outer volutions of some specimens. Parachomata rather poor in development, being low and narrow.

Remarks:-The Khao Phlong Phrab specimens resemble Presumatrina grandis in many respects, although the latter is considerably larger than the former. $P$. grandis was described by LEVEN (1967) from the Neoschwagerina simplex zone of Northern Pamir. However, the LEVEN's original material is not sufficient, represented by each one of axial and tangential section. The absence of sagittal section in the Pamir and Khao Phlong Phrab specimens makes it hard for detailed comparison between both. They may probably be conspecific with each other, although the Pamir specimens have larger size of shell and more numerous volutions than the Khao Phlong Phrab specimens.

Occurrence:-Rare at Kpp-53, -71, -73, -75, and -76. The $\mathrm{B}_{6}$ and the lower half of the $B_{\tau}$ zone. 
Table 34. Measurements of Presumatrina cfr. grandis LEvEN (in mm. unless otherwise stated)

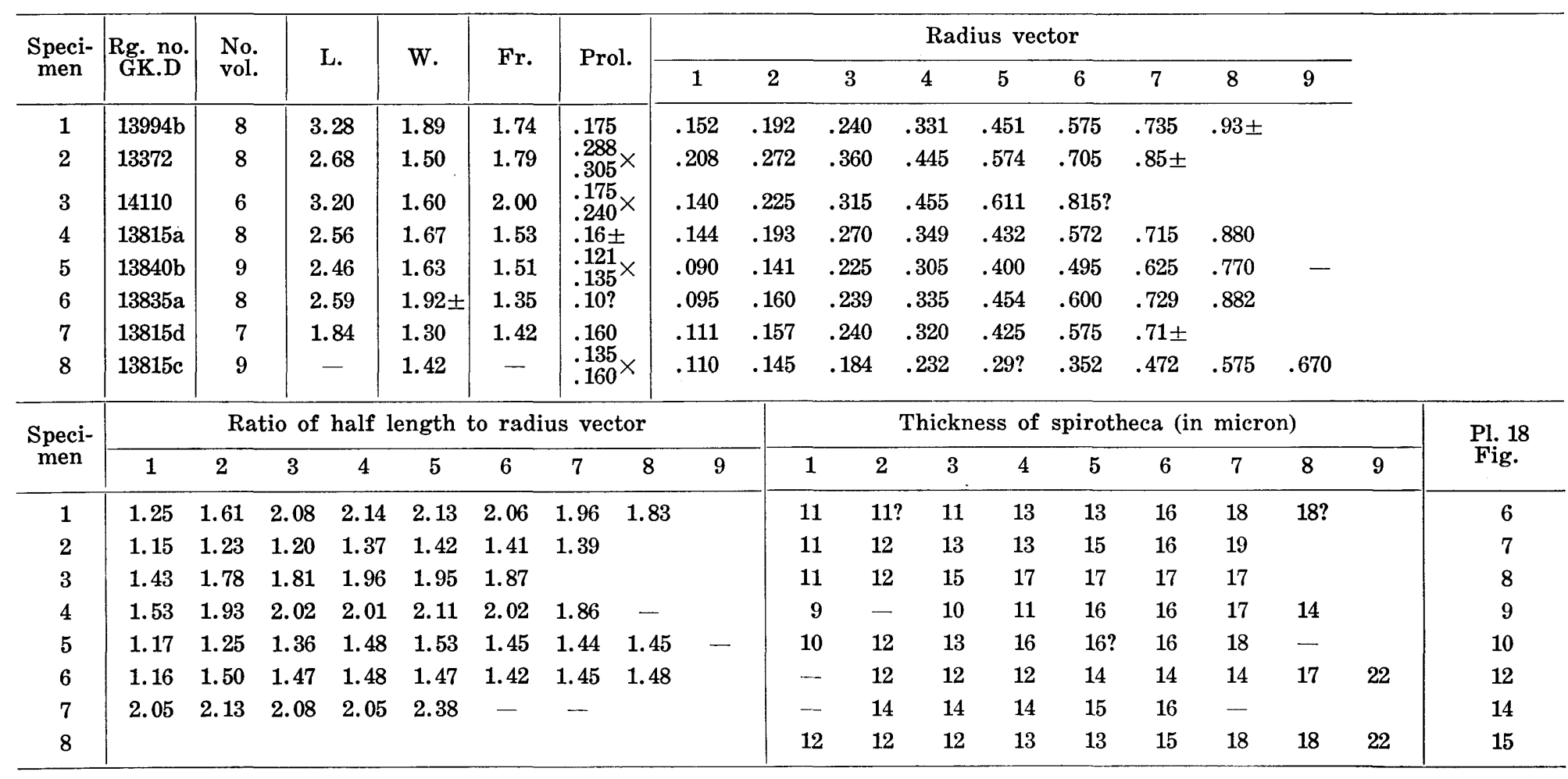


Subfamily Neoschwagerininae STAFF, 1912

Genus Neoschwagerina YABE, 1903

Neoschwagerina schuberti KOCHANSKY-DEVIDÉ

Pl. 19, Figs. 2-10

1958. Neoschwagerina schuberti Kochansky-DevidÉ. Geol. Vjesnik, Svezak XI, p. 68-70, pl. 5, figs. 1-8.

Material:-Axial sections, GK.D 14028 from Kpp-51, 13340a, 13359, 13560, and 13566 from Kpp-52, 13754 from Kpp-55, 13507b from Kpp-63, GK.D 13534 and 13542 from Kpp-71; sagittal section, GK.D 13340b from Kpp-52.

Description:-Shell small for the genus, having typical fusiform with straight axis of coiling, convex lateral slopes, and bluntly pointed poles. Mature shell of 8 to 10 volutions are 2.48 to $3.13 \mathrm{~mm}$ in length and 1.54 to $1.97 \mathrm{~mm}$ in width, giving a form ratio of 1.50 to 1.97 . The first one or two volutions nearly spherical to subspherical, and from the second or third volution shell assumes short fusiform. Outer volutions typical fusiform. Ratios of half length to radius vector of the first to tenth volutions in nine specimens average 1.50, 1.66, 1.80, 1.86, 1.86, 1.86, $1.81,1.71,1.70$, and 1.61 , respectively.

Proloculus small and spherical to subspherical, with the longest diameter of 160 microns and the shortest one of 95 microns. Inner three to four volutions coil rather tightly and the succeeding outer volutions expand moderately and uniformly. Radius vectors of the first to ninth volutions in nine specimens average 93, 139, 196, 266, 358, 461, 582, 704, and 837 microns, respectively. Height of chamber is almost the same in central two-thirds of shell, but it becomes slightly high towards the pole.

Spirotheca thin and consists of a tectum and a keriotheca whose alveolar structure is very clear in all but the first one or two volutions. Thickness of spirotheca in the first to ninth volutions in nine specimens $10,11,15,17,20,24,25$, 28 , and 27 microns, respectively in average.

Septa thick and composed of downward deflection of tectum and keriotheca. Axial septula appear in the outermost volution though very incipient in development. Primary transverse septula well developed throughout growth of shell. Secondary transverse septula not present. In some specimens, however, there are swellings of the lower surface of keriotheca between two adjacent primary transverse septula though their occurrence is a limited part of the outermost volution. Parachomata well developed throughout length of shell, except for the first volution. They are low and broad, and semicircular in profile.

Remarks:-Neoschwagerina schuberti was originally described by KoCHANSKY-DEVIDÉ (1958) from Matkovič NW of Bar in the southern Crna Gora in Jugoslavia as the most primitive representative of $N$. craticulifera lineage. The Khao Phlong Phrab specimens are nearly in accord with the Crna Gora specimens in diagnostic characteristics. In detailed comparison, however, there are some minor differences. The Khao Phlong Phrab specimens are a little larger and more slender than the Crna Gora specimens. In the latter axial septula clearly appear from the fifth volution though very rudimentary in development. In the former the development of axial septula is poorer than in the latter, though only a single axial (slightly diagonal) section has been available in the Khao Phlong Phrab material. 
Table 35. Measurements of Neoschwagerina schuberti KochANSKY-DEvidé (in mm. unless otherwise stated)

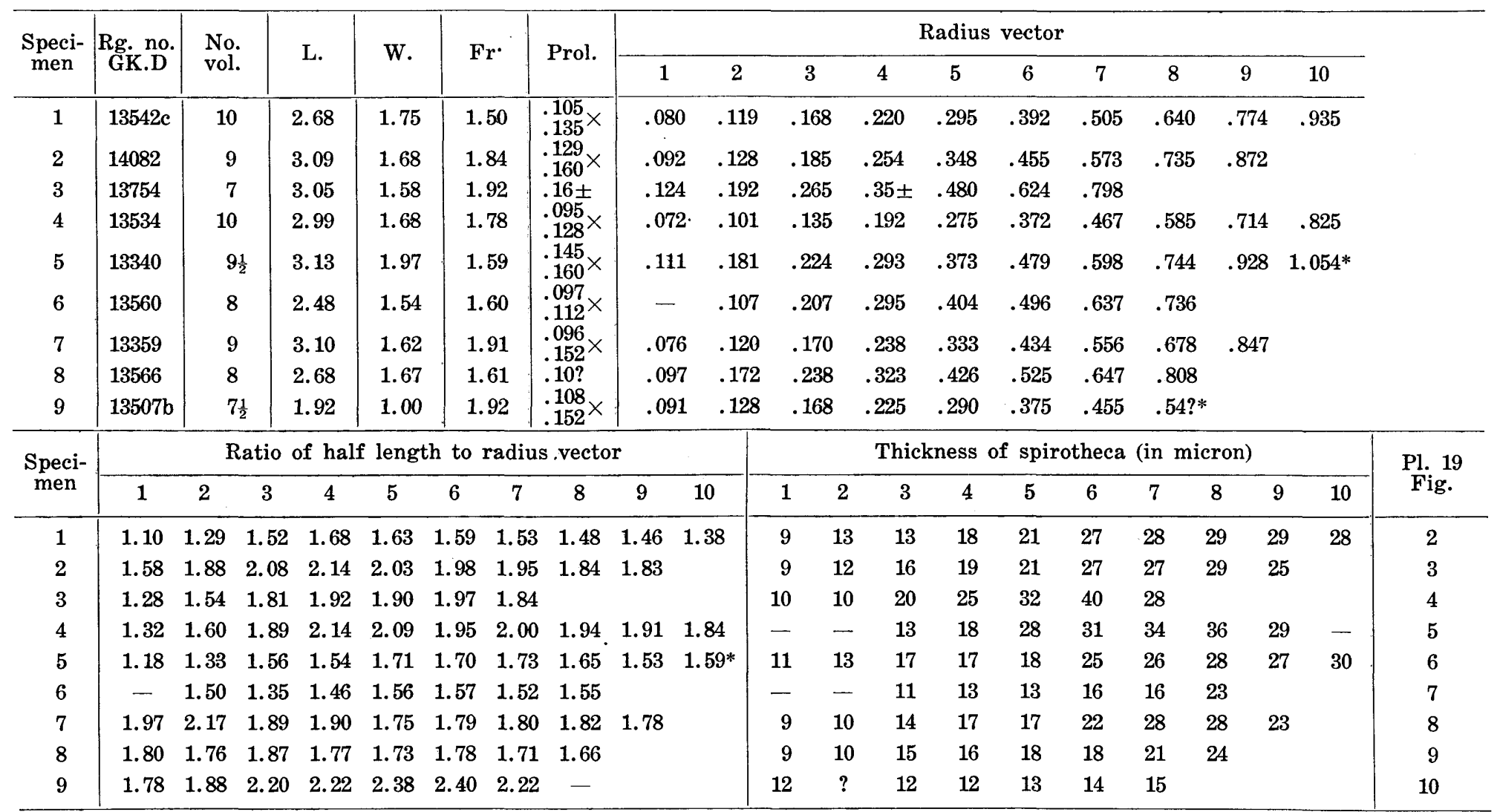

* measured a half volution earlier than others in the same column. 
As KoCHANSKY-DEvidÉ mentioned, $N$. schuberti is the most primitive representative in the $N$. craticulifera lineage. The primitive characteristics of the present species suggest that $N$. schuberti is an intermediate form between Maklaya and Neoschwagerina, and a phylogenetic lineage of Maklaya pamirica - Neoschwagerina schuberti - N. simplex tenuis $-N$. simplex simplex is considered.

Occurrence:-Abundant at $\mathrm{Kpp}-52$; common at $\mathrm{Kpp}-51,-55$, and -71 ; rare at Kpp-63 and -77 . The $B_{6}$ and the lower half of the $B_{7}$ zone.

Neoschwagerina simplex tenuis ToriYama and Kanmera, n. subsp. Pl. 19, Figs. 14-24

Material:-Holotype of the subspecies, GK.D 13470 from Kpp-61 illustrated as fig. 14 of Plate 19: Paratypes, axial sections, GK.D 13740 from Kpp-52, GK.D 13738, 13740, 13742, 13743, 13749, and 13989 from Kpp-54, GK.D 13582 and 13586 from Kpp-61; sagittal section, GK.D 13751 from Kpp-54.

Description:-Shell moderate in size and typical fusiform, with a straight axis of coiling, convex lateral slopes, and broadly rounded poles. Mature shell of 8 to 9 volutions is 3.17 to $3.90 \mathrm{~mm}$ in length and 1.58 to $2.19 \mathrm{~mm}$ in width, with a form ratio of 1.66 to 2.20 . The first one or two volutions subspherical, and the succeeding one to two volutions short fusiform, and from the fourth or fifth volution shell takes typical fusiform. Ratios of half length to radius vector in the first to ninth volutions in eight specimens average 1.55, 1.82, 1.93, 1.97, 2.04, 2.10, $2.10,2.04$, and 2.00 , respectively.

Proloculus small and spherical to subspherical, with outside diameter ranging from $104 \times 170$ to $185 \times 255$ microns, averaging 168 microns in nine specimens. Shell expands slowly in inner two or three volutions, and moderately and uniformly in outer volutions. Average radius vectors of the first to ninth volutions in ten specimens $117,167,232,309,410,520,649,796$, and 912 microns, respectively.

Spirotheca consists of a tectum and a finely alveolar keriotheca, although its minute structure is hardly observable in inner volutions. As a species of Neoschwagerina, spirotheca of the present subspecies is rather thin. Average thickness in the first to ninth volutions in ten specimens $10,12,14,15,17,19,20,22$, and 21 microns, respectively.

Septa considerably widely spaced. Septal counts of the first to eighth volutions in one specimen 8,16 ?, 16, 17?, 18?, 19?, 20, and 19?, respectively. Axial septula not present in inner volutions, but low and wide swelling of the lower surface of keriotheca begin to occur between two adjacent septa in a part of the fifth volution. Primary transverse septula well developed throughout the length of shell except in the innermost one or two volutions. They are low and broad, being one-third to a half as high as chambers.

Remarks:-Diagnostic characteristics such as the dimension of shell, the rate of expansion of shell, and primitve stage of the development of axial septula suggest that the present specimens lay within the range of Neoschwagerina simplex group. However, the former has more slender shell and thinner spirotheca and septa, and is distinguished, accordingly, from $N$. simplex simplex.

Neoschwagerina confragaspira described by LEVEN (1967) from the N. simplex zone of Southeast Pamir is rather closely similar to the present subspecies. The former is, however, distinguished from the latter in having a little larger shell and numerous number of volutions, and thicker spirotheca. Spirotheca at- 
Table 36. Measurements of Neoschwagerina simplex tenuis TORIYAMA and KANMERA, n. subsp.

(in $\mathrm{mm}$. unless otherwise stated)

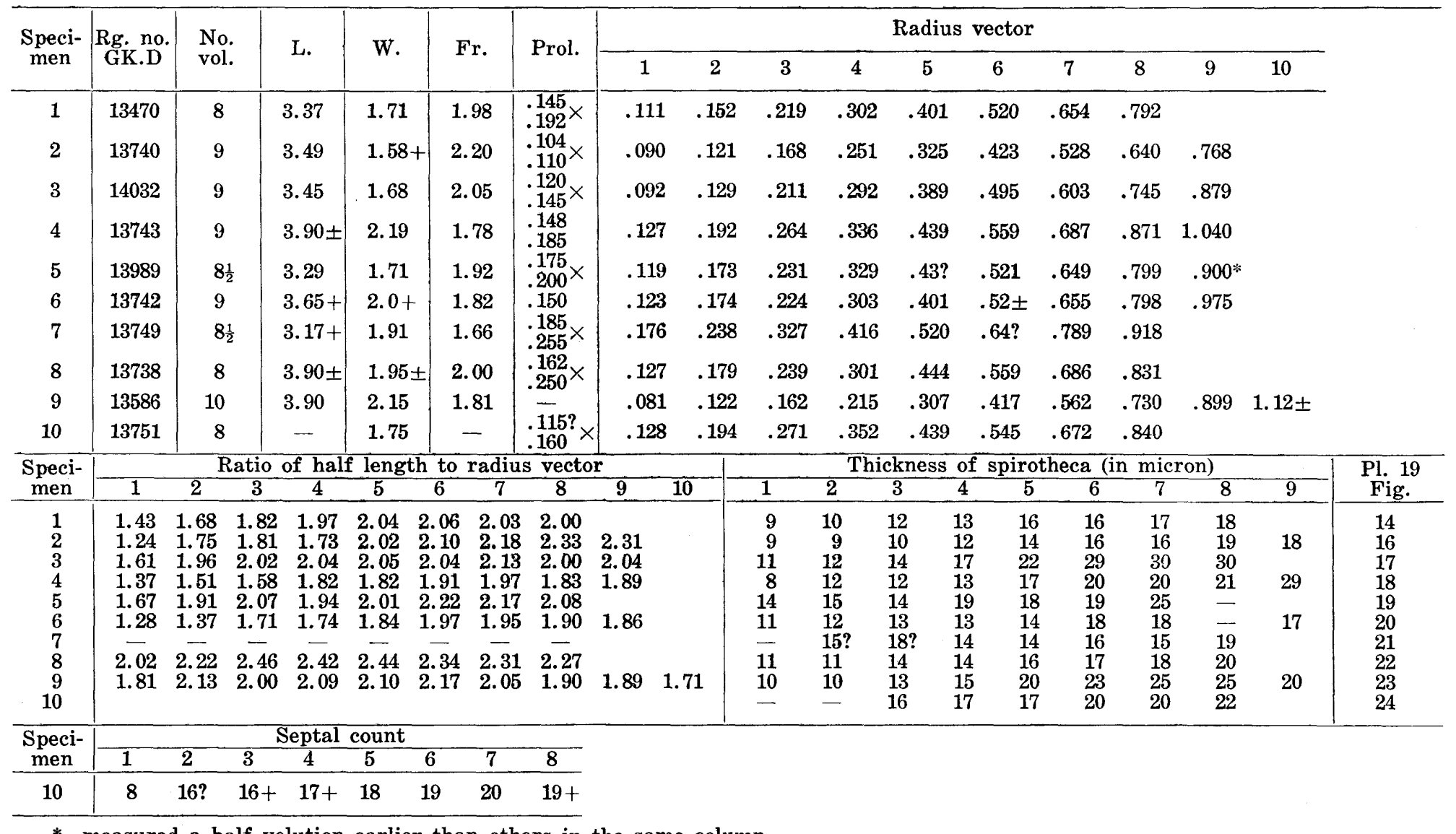

* measured a half volution earlier than others in the same column. 
tains an average thickness of 50 microns in outer volutions of $N$. confragaspira, whereas it does not exceed 30 microns in $N$. simplex tenuis.

Occurrence:-Abundant at Kpp-54, common at Kpp-52 and -61. The $\mathrm{B}_{6}$ and the basal part of the $B_{7}$ zone.

\section{Neoschwagerina simplex simplex OzAWA \\ Pl. 19, Figs. 25-28; Pl. 20, Figs. 1-21}

1927. Neoschwagerina simplex Ozawa. Jour. Fac. Sci. Imp. Univ. Tokyo, Sect. II, vol. 2, no. 3, p. 153-154, pl. 34, figs. 7-11, 22, 23; pl. 37, figs. 3a, 6 a.

1934. Neoschwagerina cf. simplex DutKevitch and Khabakov. Acad. Sci., USSR, vol. 7, pl. 2, figs. 4,5 .

1956. Neoschwagerina simplex CHen. Palaeontologia Sinica, N.S., vol. 6, no.2, p. 55-56, pl.12, figs. 13, ?14, 16 (non fig. 15).

1957. Cancellina sphaerica MikLukho-MakLAY. Uchenye Zapiski Lgu, no. 225, p. 122-123, pl. 5, fig. 1.

1957. Neoschwagerina ef. simplex KanMera. Mem. Fac. Sci., Kyushu Univ., Ser. D, vol. 6, no. 1, pl. 20, fig. 1.

1959. Neoschwagerina simplex HonJo. Jour. Fac. Sci., Hokkaido Univ., Ser. 4, vol. 10, no. 1, p. 139-142, pl. 3, figs. 1, 4, 5; pl. 4.

1959. Neoschwagerina sphaerica Honjo. Jour. Fac. Sci., Hokkaido Univ., Ser. 4, vol. 10, no. 1, p. 159, pl. 3, fig. 3 .

1960. Neoschwagerina ef. simplex KANUmA. Bull. Tokyo Gakugei Univ., vol.11, p. 67-68, pl. 11, figs. 1, 10, 11 .

1962. Neoschwagerina simplex SUYARI. Jour. Gakugei, Tokushima Univ., Nat. Sci., vol. 12, p. 36 , pl.11, fig. 1 .

1963. Neoschwagerina simplex KANMERA. Mem. Fac. Sci., Kyushu Univ., ser. D, Geol., vol.14, no. 2, p. 112-113, pl. 13, figs. 1-6; pl. 14, figs. 1-6, pl.19, fig. 15.

1967. Neoschwagerina simplex LeVen. Acad. Sci. USSR, Geol. Inst. Transact., vol. 67 , p. 189-190, pl. 32, figs. 8-10.

1970. Neoschwagerina simplex OzAWA. Mem. Fac. Sci., Kyushu Univ., Ser. D, Geol., vol. 20, no. 1, pl. 4, figs. 9-11.

Lectotype:-The specimen illustrated as fig. 8 of OzAwA's pl. 34 (1927), designated by HoNJo (1959).

Material:-Axial sections, GK.D 13674 and 13981 from Kpp-51, GK.D 13232, 13234, 13340, 13354, 13558 from Kpp-52, GK.D 13363a, 13363b, 13363c, 13367, 13371a, 13371c, and 14097 from Kpp-53, GK.D 13486 from Kpp-61, GK.D 13504, 13506 and 13509 from Kpp-63; sagittal sections, GK.D 13608b and 13981 from Kpp-51, GK.D 13230b, 13230c, 13351, 13356 and 13564b from Kpp-52, GK.D 14097 from Kpp-53, GK.D 13502 and 13507c from Kpp-63, and GK.D 13997 from Kpp-73. Many other sectioned specimens are referred to this subspecies.

Description:-Shell is moderate in size for the genus Neoschwagerina, and is subspherical to thick fusiform with a straight to slightly shifting axis of coiling, convex lateral slopes and broadly rounded poles. Mature shell of 9 to 10 volutions attains a length of 2.52 to $4.26 \mathrm{~mm}$ and a width of 2.08 to $2.84 \mathrm{~mm}$, giving average form ratio of 1.33 in ten specimens. Inner three to four volutions assume spherical to subspherical form, and from the fourth or fifth volution shell takes thick fusiform. Ratios of half length to radius vectors of the first to ninth volutions in nine specimens average $1.18,1.22,1.35,1.33,1.37,1.39,1.39,1.37$, and 1.35 , respectively. 
Table 37. Measurements of Neoschwagerina simplex simplex OzAWA (in mm. unless otherwise stated)

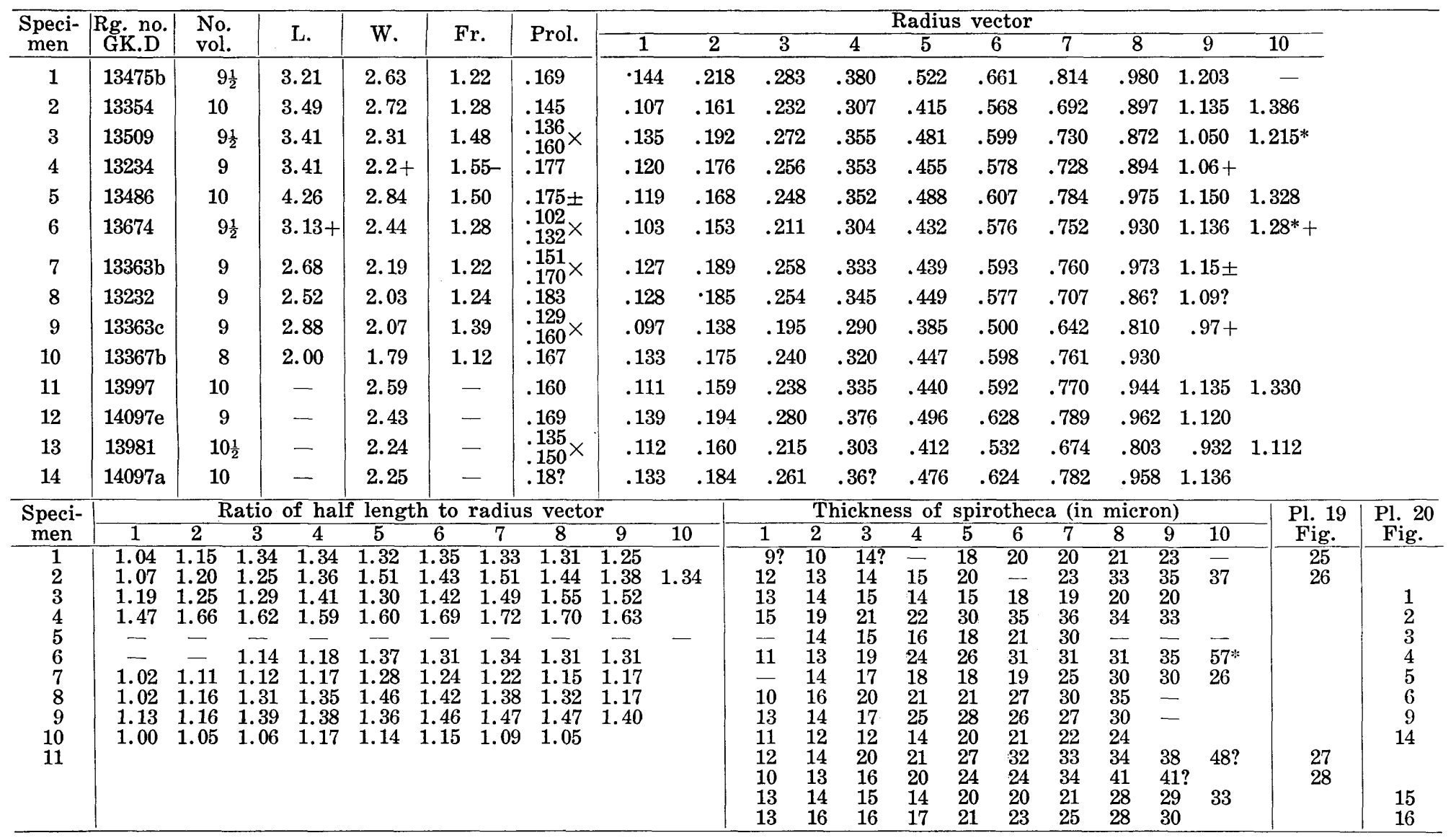

* measured a half volution earlier than others in the same column. 
Proloculus small and spherical in most of the specimens, but in some it takes ellipsoidal shape with the longest diameter of 183 microns and the shortest one of 102 microns. Expansion of shell is very slow in the first one to two volutions and becomes less slow and uniform in the succeeding volutions. Average radius vectors of the first to tenth volutions in fourteen specimens are 122, 175, 246, 337, 453, $588,742,913,1097$, and 1289 microns, respectively. Chambers is nearly the same in height throughout the length of shell.

Spirotheca is thin in inner few volutions but becomes thicker in out volutions where alveolar structure is shown very clearly. Thickness of spirotheca of the first to tenth volutions in fourteen specimens averages $12,15,16.5,17,22,23,27,30,31$, and 36 microns, respectively.

Septa thick and the same in structure as spirotheca. Axial septula not occur in inner three to five volutions, and one axial septulum appears between two adjacent septa in outer volutions, though very primitive in development, being only low swelling of the lower surface of keriotheca. The primary transverse septula well developed throughout the length of shell. The secondary transverse septula not develop in most part of shell, but in a limited part of outer volutions in some specimens, they rarely appear as a broad swelling of the lower surface of spirotheca.

Remarks:-Neoschwagerina simplex is a good guide species for the lower part of the Neoschwagerina zone, and has been reported widely in Tethys Sea region, from the Akasaka Limestone to Crimea through the Kozaki Limestone, Maokou Limestone of South China, and Pamir. Since KANMERA (1963) discussed the species at length, it seems unnecessary to add further comments.

Occurrence:-Abundant at Kpp-52, -53, -54, -61, -63, -71, and -73; common at $\mathrm{Kpp}-51,-55$, and -57 ; rare at $\mathrm{Kpp}-70$ and -79 . Whole range of the $\mathrm{B}_{6}$ and the lower half of the $\mathrm{B}_{7}$ zone.

\section{Neoschwagerina sp. A \\ Pl. 19, Figs. 11-13}

Material:-Axial section, GK.D 14093 from Kpp-58; sagittal section, GK.D 14092 from Kpp-58.

Description:-Shell is thick discoidal with nearly straight axis of coiling, convex lateral slopes and broadly rounded periphery. The axis of coiling is the shortest diameter. Only available axial section is $2.30 \mathrm{~mm}$ in length and $2.82 \mathrm{~mm}$ in width, giving a form ratio of 0.82 . Although the section is not exactly oriented, the first volution seems to coil at large angles to later volutions. Ratios of half length to radius vector of the second to tenth volutions $0.67,0.77,0.83,0.91,0.87$, $0.85,0.88,0.83$, and 0.83 , respecively.

Proloculus minute, with outside diameter of 47 microns. Shell coils nearly uniformly except for the first volution. Radius vectors of the first to eleventh volutions in the axial section are $77,119,168,232,335,480,655,840,1080,1335$, and 1570 microns, respectively. Those of the first to eighth volutions in the sagittal section are $128,210,305,420,560,690,865$, and 1010 microns, respectively. Chamber is nearly the same in height from the median portion of shell to poles in inner volutions, but it is highest in the median portion of shell in outer volutions, decreasing in height towards pole.

Spirotheca thick, consisting of a tectum and a finely alveolar keriotheca, although minute structure is hardly observable in inner few volutions. Thickness 
of spirotheca measured in the axial section $11,12,20,24,39,44,44,53$, and 60 microns, respectively in the second to tenth volutions.

Septa thick and the same in structure as spirotheca. Septal counts of the third to eighth volutions are 11?,15?,16?,21?,26?, and 23?, respectively. Axial septula not present, but incipient swelling of the lower surface of keriotheca is observable in a limited part of the fourth to the last volution. Primary transverse septula well developed throughout all but the first volution. No secondary transverse septula present, but the lower surface of keriotheca begins to swell very slightly and rarely in outer volutions. Parachomata low and broad, being one-third to a half as high as chamber.

Remarks:-No species of Neoschwagerina is comparable with the present species which has a form ratio of less than an unit. Although it may be probable that the present specimen of axial section was compressed in the direction of the axis, resulting in that the shell assumed a discoidal shape, there is no clear evidence to show the secondary deformation after the fossilization in the specimens found in the limestone of Loc. Kpp-58. It is therefore preferable that the discoidal shape of shell in the present species is not secondary, but original in specific characteristics.

In the developmental stage of axial and secondary transverse septula and parachomata the present species is compared with Neoschwagerina simplex and its allies.

Occurrence:-Rarely found at Kpp-58. The upper part of the $\mathbf{B}_{6}$ zone.

\section{Neoschwagerina sp. B}

Pl. 19, Fig. 1

Material:-Axial (more or less diagonal) section, GK.D 13840d from Kpp-75.

Description:-Since a single section has been available for Neoschwagerina sp. B which is not exactly oriented, the following description is far from the completeness.

Shell ellipsoidal, with axial length of $2.72 \mathrm{~mm}$ and median width of $1.78 \mathrm{~mm}$ and a form ratio of 1.53. Ratios of half length to radius vector in the first to eighth volutions $1.53,1.60,1.78,1.80,1.83,1.85,1.89$, and 1.71 , respectively.

Proloculus small and subspherical with outside diameter of $120 \times 160$ microns. Expansion of shell is slow in inner two volutions, but becomes less slow and uniform in outer volutions. Radius vectors of the first to ninth volutions $95,150,225$, $320,430,520,650,815$, and 950 (?) microns, respectively.

Spirotheca rather thin and composed of a tectum and a keriotheca. In the latter fine alveolar structure has not so clearly been observed probably because of secondary mineralization. Thickness of spirotheca of the first to eighth volutions $13,16,16,18,21,21,21$, and 21 microns, respectively.

Characters of septa and axial septula unknown because of absence of sagittal section. Primary transverse septula occur throughout growth. Secondary transverse septula appear in the fourth and fifth volutions as short downward extension of the lower surface of keriotheca and in outer volutions one secondary transverse septulum presents between each pair of primary transverse septula, though it is not necessarily found in all parts of outer volutions. Parachomata develop in all but the first volution, being low and broad.

Remarks:-The present material is too insufficient to make a detailed specific 
comparison. However, the appearance of secondary transverse septula partly in outer volutions suggests that Neoschwagerina sp. B is in the developmental stage of $N$. craticulifera in the $N$. simplex $-N$. craticulifera $-N$. margaritae lineage.

Occurrence:-Rare at $\mathrm{Kpp}-75$. The middle part of the $\mathrm{B}_{7}$ zone.

\section{Genus Colania LeE, 1933 \\ Colania douvillei (OzAWA) \\ Pl. 20, Figs. 22-26}

1906. Neoschwagerina globosa Douvillé (non YABE, 1906). Bull. Soc. Géol. France, Ser. 4, vol. 6, p. 182, pl. 17, pl. 18, figs. 1-2.

1912. Neoschwagerina globosa DePrat (non YABE, 1906). Mém. Serv. Géol. l'Indochine, tome 1, fasc. 3, p. 51, pl. 4, figs. 1-4.

1913. Neoschwagerina globosa DEPRAT (non YABE, 1906). Mém. Serv. Géol. l'Indochine, tome 2, fasc. 1, p. 55.

1914. Neoschwagerina globosa Deprat (non YABE, 1906). Mém. Serv. Géol. l'Indochine, tome 3 , fasc. 1 , p. 29-30.

1922. Neoschwagerina douvillei OzAWA. Jour. Geol. Soc. Tokyo, vol. 29, no. 348, p. 368-372.

1924. Neoschwagerina globosa Colani (non YaBe, 1906). Mém. Serv. Géol. l'Indochine, tome 6, fasc. 1, p. 152-153, pl. 23, figs. 1, 2, 4-14, 23-34, 36-38; pl. 25 , figs. 9, 13a-c, pl. 26, figs. 3-5.

1956. Neoschwagerina douvillei CHEN. Palaeont. Sinica, N.S., B, no. 6, p.12, 58, 69, pl. 13, figs. 3-7, pl. 14, fig. 7.

1956. Yabeina proboscis Chen. Palaeont. Sinica, N.S., B, no. 6, p. 66, pl. 13, figs. 8-10 (microspheric form).

1967. Neoschwagerina douvillei Igo. Geol. Palaeont. Southeast Asia, vol. 3, pl. 7, figs. 6-8, pl. 8, fig. 7 .

1967. Neoschwagerina sp. A, Igo. Geol. Palaeont. Southeast Asia, vol. 3, pl. 8, figs. 5-6.

1970. Colania sp. nov. Ozawa. Mem. Fac. Sci. Kyushu Univ., Ser. D, Geol., vol. 20, pl. 1, figs. 2, 6-7, pl. 7, figs. 5-7.

Material:-Axial sections, GK.D 14100, 14101, 14103, 14205, and 14208; sagittal section, GK.D 14208. All from Kpp-77.

Descriptive remarks:-OzAWA (1970b) studied the materials collected by ToRIYAMA and KANMERA from Khao Imot, near Khao Phlong Phrab very much in detail from biostatistic point of view, and made clear that $C$. douvillei is dimorphic, having megalospheric and microspheric forms in the life cycle. He also made clear individual variations in several important characteristics by quantative analysis.

Since the specimens obtained from Khao Phlong Phrab section well agree with those from Kho Imot in all the important specific features, further description and discussion is unnecessary except for giving the measurements of the Khao Phlong Phrab specimens.

It is noted that, according to OzAWA, "Neoschwagerina douvillei" reported from many localities in Japan considerably different from Colania douvillei from Southeast Asia in the proloculus size, radius vector, form ratio, and septulal pattern, and should be assigned to a distinct species of Colania.

Occurrence:-Common at Kpp-77. The middle part of the $\mathrm{B}_{7}$ zone. 
Table 38. Measurements of Colania douvillei (OzAWA) (in mm. unless otherwise stated)

\begin{tabular}{|c|c|c|c|c|c|c|c|c|c|c|c|c|c|c|c|c|c|c|c|c|}
\hline \multirow{2}{*}{$\begin{array}{l}\text { Speci- } \\
\text { men }\end{array}$} & \multirow{2}{*}{$\begin{array}{l}\text { Rg. no. } \\
\text { GK.D }\end{array}$} & \multirow{2}{*}{\multicolumn{2}{|c|}{$\begin{array}{l}\text { No. } \\
\text { vol. }\end{array}$}} & \multirow{2}{*}{ L. } & \multirow{2}{*}{ w. } & \multirow{2}{*}{\multicolumn{2}{|c|}{ Fr. }} & \multirow{2}{*}{ Prol. } & \multicolumn{11}{|c|}{ Radius vector } & \\
\hline & & & & & & & & & 1 & & 2 & 3 & 4 & 5 & 6 & 7 & 8 & 9 & 10 & \\
\hline 1 & 14103 & 10 & & 6.01 & 2.84 & & 2.12 & $.364 \times$ & .2 & & .325 & .401 & .523 & .671 & .810 & .962 & 1.024 & $1.320 \quad 1$ & $1.472^{*}$ & \\
\hline 2 & 14101 & 10 & & 5.73 & 2.64 & & 2.17 & $.423 \times$ & .2 & & .359 & .432 & .525 & .651 & .772 & .935 & 1.065 & $\begin{array}{ll}1.201 & 1\end{array}$ & $1.40 \pm$ & \\
\hline 3 & 14205 & 8 & $\frac{1}{2}$ & 3.90 & 1.95 & & 2.00 & $.266 \times$ & .1 & & .257 & .320 & .411 & .512 & .616 & .745 & $.89 \pm$ & $=1.025^{*}$ & & \\
\hline 4 & 14100 & 8 & & 3.58 & 1.79 & & 2.00 & $.215 \times$ & .1 & & .216 & .293 & .375 & .470 & .615 & .761 & .895 & & & \\
\hline 5 & 14208 & 8 & & - & 1.92 & & - & $.373 x$ & .2 & & .320 & .392 & .471 & .575 & .705 & .817 & .962 & & & \\
\hline \multirow{2}{*}{$\begin{array}{c}\text { Speci- } \\
\text { men }\end{array}$} & \multicolumn{10}{|c|}{ Ratio of half length to radius vector } & & \multicolumn{8}{|c|}{ Thickness of spirotheca (in micron) } & \multirow{2}{*}{$\begin{array}{l}\text { Pl. } 20 \\
\text { Fig. }\end{array}$} \\
\hline & 1 & 2 & 3 & 4 & 5 & 6 & 7 & 8 & 9 & 10 & 1 & 2 & 3 & 4 & 5 & 6 & 7 & 9 & 10 & \\
\hline 1 & 1.34 & 1.77 & 2.23 & 32.72 & 2.50 & 2.41 & 2.32 & 2.42 & 2.06 & - & & 12 & 13 & 15 & 16 & 16 & 16 & 20 & $21^{*}$ & 22 \\
\hline 2 & 1.82 & 2.00 & 1.97 & 2.01 & 2.07 & 2.27 & 2.17 & 2.17 & 2.17 & 2.03 & & 13 & 14 & 18 & $18 ?$ & 18 & 19 & 21 & $27 ?$ & 23 \\
\hline 3 & 1.49 & 1.88 & 2.09 & 2.18 & 2.16 & 2.32 & 2.25 & 2.12 & & & & 14 & $15 ?$ & 15 & 17 & 17 & 18 & - & & 24 \\
\hline 4 & 2.17 & 2.13 & 2.02 & 2.27 & 2.32 & 2.13 & 2.08 & 1.97 & & & & 12 & 14 & 14 & $15 ?$ & 16 & 16 & 19 & & 25 \\
\hline 5 & & & & & & & & & & & & 12 & 13 & 15 & 14 & 15 & 15 & 15 & & 26 \\
\hline \multirow{2}{*}{$\begin{array}{c}\text { Speci- } \\
\text { men }\end{array}$} & \multicolumn{9}{|c|}{ Septal count } & & & & & & & & & & & \\
\hline & 1 & 2 & 3 & 4 & 5 & 6 & 7 & 8 & 9 & & & & & & & & & & & \\
\hline 5 & $13 ?$ & $14 ?$ & $16 ?$ & $16 ?$ & $19 ?$ & $20 ?$ & - & $21 ?$ & & & & & & & & & & & & \\
\hline
\end{tabular}

* measured a half volution earlier than others in the same column. 
Family Staffellidae MiklukHo-MaKalay, 1949

Subfamily Staffellinae MikLukho-Makalay, 1949

Genus Nankinella LEE, 1933

Nankinella hunanensis (CHEN)

Pl. 21, Figs. 1-8

1956. Ozawainella hunanensis Chen. Palaeont. Sinica, N.S., B, no. 6, p. 18, pl.1, figs. 1-3.

Material:-Axial sections, GK.D 13016a, 13017 and 13019 from Kpp-37, GK.D 13118 and 13119 from Kpp-39, GK.D 13388 from Kpp-56, GK.D 13478 and 14381 from Kpp-61; sagittal section, GK.D 13129 from Kpp-39.

Description:-Shell small and thickly discoidal, with a short axis of coiling and straight to gently convex lateral slopes. Periphery rather angular in the first two, and becomes rounded in the succeeding four to five volutions, but more or less angular again in outer one or two volutions. Mature shell of 8 to 10 volutions 1.22 to $2.12 \mathrm{~mm}$ in length and 1.89 to $3.34 \mathrm{~mm}$ in width, giving form ratios of 0.56 to 0.89 . The first one or two volutions probably evolute. Beyond the second or third volution shell assumes nearly the same axial profile. Ratios of half length to radius vector of the second to ninth volutions in seven specimens average $0.46,0.48,0.70$, $0.67,0.70,0.72,0.68$, and 0.61 , respectively.

Proloculus small and spherical, probably with outside diameter of less than 80 microns. Sagittal section referred to this species with a query has a relatively large proloculus for size of shell, having outside diameter of 120 microns. Shell expands almost uniformly, with average radius vectors of the first to ninth volutions in eight specimens $108,182,289,408,521,648,793,998$, and 1262 microns, respectively. Chambers highest at the median portion of shell, decreasing in height gradually towards pole.

Spirotheca thin, with average thickness of $13,14,16,16,17,19,20$, and 22.5 microns, respectively in the first to eighth volutions in five specimens. Minute structure of spirotheca hardly observed due to secondary mineralization.

Tunnel high and narrow, with a tunnel angle of about $10^{\circ}$ in outer volutions. Tunnel path nearly straight. Chomata present in outer volutions where they are massive with steep tunnel side and gentle poleward slopes.

Remarks:-Nankinella hunanensis was originally described by CHEN (1956) as a species of Ozawainella from the lower part of the Chinghsichung Limestone of Hut'ein, Hunan and the Maokou Limestone at Chienkiang, Kwangsi, South China. SHENG (1963) and KAHLER and KAHLER (1966) assigned the species to Nankinella.

$N$. hunanensis resembles $N$. nagatoensis TORIYAMA in many respects, and they may probably be conspecific with each other. Difference between them is that the former has a little larger size of shell, more numerous volutions, and slightly slower rate of expansion. N.hunanensis is also similar to $N$. quasihunanensis described by SHeng (1963) from the Codonofusiella zone of the Wuchiaping Limestone near Zisongzheng of Wangmo, Kueichow Province, South China, but, as pointed out by SHENG, $N$. quasihunanensis has a larger shell, a thicker spirotheca, more convex umbilical areas, and a larger proloculus.

The Khao Phlong Phrab specimens are identical in most of essential shell characteristics with the CHEN's original form, although there is a considerable 
Table 39. Measurements of Nankinella hunanensis (CHEN) (in mm. unless otherwise stated)

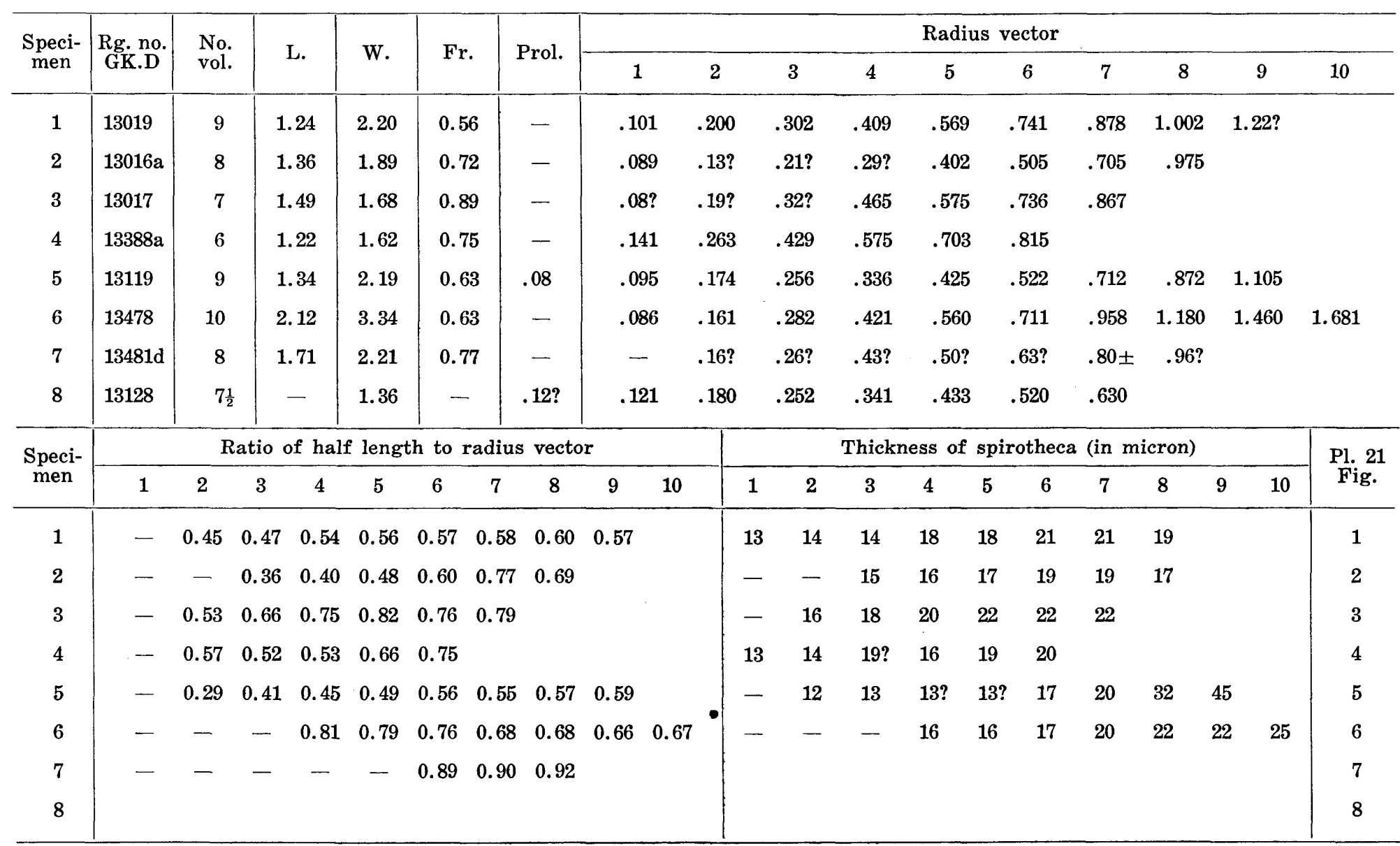


variation in the dimension of shell in the former as well as in the latter.

Occurrence:-Rare at Kpp-37, $-39,-56$, and -63 . The uppermost part of the $\mathrm{B}_{4}$ to the basal part of the $\mathrm{B}_{7}$ zone.

\section{Nankinella cfr. inflata (COLANI) \\ Pl. 21, Figs. 9-11}

1924. Fusulinella inflata Colani. Mém. Serv. Géol. l'Indochine, tome 11, fasc. 1, p. 77, pl. 15 , figs. $3-5,7-10,13,15$.

1935. Staffella inflata Gubler. Mém. Soc. Géol. France, N.S. 11, fasc. 4, Feuilles 36-57, no. 26, p. 77-78, pl. 3, figs. 9-14.

1956. Nankinella inflata CHeN. Palaeont. Sinica, N.S., B, no.6, p. 2,19, pl.1, figs. 4-7.

1963. Nankinella inflata Sheng. Palaeont. Sinica, N.S., B, no. 10, p.155, pl. 3, figs. 1-5.

Material:-Axial sections, GK.D $14208 \mathrm{~b}$ and 14210 from Kpp-77; sagittal sections, GK.D. 14208a and 14210 from Kpp-77; excentric section, GK.D 14207 from Kpp-77.

Description:-Shell inflated discoidal and large for the genus, with a short axis of coiling and gently convex lateral slopes. A typical axial section of $8 \frac{1}{2}$ volutions attains a length of $1.57 \mathrm{~mm}$ and $1.97 \mathrm{~mm}$ in width, giving a form ratio of 0.80 . Inner two to three volutions have slightly thin discoidal axial profile with somewhat angular periphery. Outer volutions nearly the same in axial profile. Ratios of half length to radius vector of the first, sixth to eighth volutions in the axial section mentioned above $0.66,0.88,0.91$, and 0.91 , respectively.

Proloculus spherical and considerably large for the size of shell, with outside diameter of 180 to 200 microns. Shell expands almost uniformly throughout growth. Radius vectors of the first to tenth volution of a typical sagittal section (GK.D 13208a) $110,192,245,321,405,510,610,745,883$, and 1034 microns, respectively.

Spirotheca thin and consists apparently of a tectum and a less dense lower layer, but minute structure of the latter is not recognized. Thickness of spirotheca of the first to tenth volutions $13-14,14-15,15-16,17-18,17-18,19-20,18-20$, 20-21, 20, and 22 microns, respectively.

Septa completely plane and numerous in number. About 30 septa counted in the seventh volution in one sagittal section. Chomata poorly developed, being only low deposits on the upper surface of spirotheca in outer few volutions. Tunnel not well defined.

Remarks:-Although the Khao Phlong Phrab specimens are not enough in number, the diagnostic characteristics of shell, such as the shape and dimension and spirothecal structure, are nearly the same with those of Nankinella inflata described by CHEN (1956) and SHeng (1963) from South China. The Khao Phlong Phrab specimens may probably be identified with the South Chinese species.

In the Kwangsi Province $N$. inflata occurs in certain beds of the Maokou Limestone of Chungshan Province without any association of other species, whereas in the Kueichow Province it is one of the characteristic species for the Wuchiaping Limestone near Zisongzheng of Wangmo. Therefore, this species ranges stratigraphically from the Middle to Upper Permian.

Occurrence:-Rare at Kpp-77. The middle part of the $\mathrm{B}_{7}$ zone. 
Nankinella cfr. discoides (LEE)

Pl. 21, Figs. 12-16

1931. Staffella discoides Lee. Bull. Geol. Soc. China, vol. 10, p. 286, pl. 1, figs. 1, 1 .

1933. Nankinella discoides LEE. Mem. Nat. Res. Inst. Geol., vol.14, p. 15.

1950. Nankinella discoides Hanzawa. Short Papers, Inst. Geol. Palaeont. Tohoku Univ., Sendai, p. 3-5, pl. 2, figs. 1-6, 8.

1963. Nankinella discoides Sheng. Palaeont. Sinica, N.S., B, no. 10, p. 154, pl. 3 , fig. 6.

Material:-Axial sections, GK.D 13056 from Kpp-30, GK.D 13727 from Kpp-34, GK.D 13085 from Kpp-37, and GK.D 13490 from Kpp-61.

Description:- Shell moderate to large in size and thickly discoidal, with short axis of coiling and broadly rounded periphery. Largest specimen of 13 volutions $2.03 \mathrm{~mm}$ in length and $3.74 \mathrm{~mm}$ in width, giving a form ratio of 0.54 . Most of specimens of 9 to 10 volutions 1.55 to $1.62 \mathrm{~mm}$ in length and 2.30 to $2.45 \mathrm{~mm}$ in width, with form ratios of 0.54 to 0.68 . The first three to four volutions seem to be lenticular with sharply angular periphery, and from the fourth or fifth volution shell expands nearly uniformly with axial profile of cocoon shape. Ratios of half length of radius vector of the first to third and the sixth to tenth volutions in one specimen $0.45,0.57,0.59,0.70,0.68,0.65,0.63$, and 0.60 , respectively.

Proloculus small and spherical. Outside diameter about 130 microns in one specimen and 72 microns in the other one. Expansion of shell slow in inner three volutions and almost uniform from the fourth volution to maturity. Radius vectors of the first to ninth volutions in four specimens average 138, 213, 303, 407, 523, $639,783,964$, and 1139 microns, respectively.

Spirotheca thin in inner volutions, but relatively thick in outer ones. Minute structure of spirotheca not clear due to secondary mineralization. Average thickness of spirotheca of the fifth to tenth volutions in four specimens 19, 19, 21, 23, 27, and 34 microns, respectively.

Septa plane throughout growth of shell. Chomata present in outer volutions, though poor in development, being low and broad with a height less than a half of chamber height.

Remarks:-The Khao Phlong Phrab specimens are similar to Nankinella discoides described by LEE (1931) from the Chihsia Limestone at Nanking hill, but are distinguished from the latter by having a considerably smaller shell. SHENG (1963) also described this species from the Chihsia Limestone near Pingding, Yishan, Kwangsi. His specimen is lesser in number of volution and smaller in size of shell than the type specimen of LEE, though SHENG mentioned that his specimen may be a sub-mature individual. The Khao Phlong Phrab specimens are almost identical in diagnostic characteristics to the Pingding specimen, and both are probably conspecific with each other.

Occurrence:-Rare at Kpp-30, $-34,-37,-61$, and -77 . The stratigraphic range is wide, covering the $B_{4}$ to the lowest part of the $B_{7}$ zone. 
Table 40. Measurements of Nankinella cfr. discoides (LEE) (in mm. unless otherwise stated)

\begin{tabular}{|c|c|c|c|c|c|c|c|c|c|c|c|c|c|c|c|c|c|c|c|c|c|c|c|c|c|c|}
\hline \multirow{2}{*}{$\begin{array}{c}\text { Speci- } \\
\text { men }\end{array}$} & \multirow{2}{*}{$\underset{\text { GK. no. }}{\text { Rg. no. }}$} & \multirow{2}{*}{$\begin{array}{l}\text { No. } \\
\text { vol. }\end{array}$} & \multirow{2}{*}{\multicolumn{2}{|c|}{ L. }} & \multirow{2}{*}{$\mathrm{W}$. } & \multirow{2}{*}{ Fr. } & \multirow{2}{*}{ Prol. } & \multicolumn{17}{|c|}{ Radius vector } & \multirow{2}{*}{\multicolumn{2}{|c|}{$\begin{array}{c}\text { Pl. } 21 \\
\text { Fig. }\end{array}$}} \\
\hline & & & & & & & & \multicolumn{6}{|c|}{6} & \multicolumn{2}{|c|}{7} & 8 & \multicolumn{2}{|c|}{9} & 10 & \multicolumn{2}{|c|}{11} & \multicolumn{3}{|l|}{12} & & \\
\hline 1 & 13727 & 10 & 1. & & $2.54 ?$ & 0.66 & .072 & .113 & 3.176 & 6.25 & .371 & .481 & .612 & .77 & & .946 & & 120 & 1.30 & & & & & & & 13 \\
\hline 2 & 13085 & 9 & 1. & 55 & 2.30 & 0.67 & - & $.16 ?$ & $? .24 ?$ & .35 & $.45 ?$ & .575 & $5 ? .685$ & $? .83$ & $30 ?$ & $1.025 ?$ & & $25 ?$ & & & & & & & & 14 \\
\hline 3 & 13056 & 9 & 1. & 58 & 2.32 & 0.68 & $.13 \pm$ & .141 & 1.222 & 2.30 & .401 & 1.512 & .619 & .74 & & .925 & & 105 & & & & & & & & 15 \\
\hline 4 & 13490 & $13 ?$ & 2.0 & 03 & 3.74 & 0.54 & - & - & - & - & - & - & - & - & & $.96 ?$ & & $08 ?$ & $1.26 ?$ & & $46 ?$ & 1.64 & & $94 ?$ & & 16 \\
\hline \multirow{2}{*}{$\begin{array}{c}\text { Speci- } \\
\text { men }\end{array}$} & \multicolumn{13}{|c|}{ Ratio of half length to radius vector } & \multicolumn{13}{|c|}{ Thickness of spirotheca (in micron) } \\
\hline & 1 & 2 & 3 & 4 & 5 & 6 & 7 & 8 & 9 & 10 & 11 & 12 & 13 & 1 & 2 & 3 & 4 & 5 & 6 & 7 & 8 & 9 & 10 & 11 & 12 & 13 \\
\hline 1 & 0.45 & 0.57 & 0.59 & - & - & 0.70 & 0.68 & 0.65 & 0.63 & 0.60 & & & & - & 14 & 18 & - & 20 & 20 & $21 ?$ & 21 & 29 & 35 & & & \\
\hline 2 & - & - & - & 0.42 & $12 \quad 0.47$ & 0.54 & 0.60 & 0.62 & 0.63 & & & & & - & $\ldots$ & - & - & - & 18 & 19 & 24 & 27 & & & & \\
\hline 3 & - & - & - & - & 0.59 & 0.61 & 0.73 & 0.71 & 0.72 & & & & & - & - & - & - & 18 & 19 & 22 & 23 & 29 & & & & \\
\hline 5 & & & & & & & & & & & & & & & & & & & & & & & & & & \\
\hline
\end{tabular}




\section{Genus Sphaerulina LEE, 1933 \\ Sphaerulina sp. \\ Pl. 21, Fig. 21}

Material:-Excentric section, GK.D 13224 from Kpp-52.

Description:-Only a single specimen has been available for the present species. Since the section is cut obliquely not through the center of shell, the following description is not complete.

Shell small and probably subspherical or almost spherical, with about $2.0 \mathrm{~mm}$ in length and width. Size and shape of proloculus, and mode of coiling of inner volutions unknown. Radius vectors increase almost uniformly in outer volutions, being $197,311,421,521,694,822$, and 941 microns, respectively in probably third to ninth volutions.

Due to secondary mineralization, spirothecal structure has been much replaced, but, so far has been seen, spirotheca seems to be composed of two layers, a thin upper layer and a thicker lower layer, in the latter of which fibrous structure is faintly observed. Thickness of spirotheca in the outer seven (probably third to ninth) volutions 22 ?, 23 ?, 23, 29, 30, 30, and 33 microns, respectively.

Septa also affected by secondary mineralization. They are plane throughout the growth of shell, and rather widely spaced. Character of chomata and tunnel unknown.

Remarks:-In the shape and size of shell and the rate of expansion in outer seven volutions, the present species may probably be referable to Sphaerulina crassispira japonica, which was first described by KANMERA (1963) from the Kozaki Formation, South Kyushu, Japan, and later by PiTAKPaIVAN (1965) from the Chondhurian Limestone, Nakhorn Sawan, Central Thailand. However, the present species is represented but only a single excentric section, and some of diagnostic characteristics, as well as the exact values of mensurable characteristics, are not known. Further study on enough material is necessary before the definite specific assignment can be done.

Occurrence:-Only known at Kpp-52. The lower part of the $\mathrm{B}_{6}$ zone.

Genus Eoverbeekina LEE, 1933

Eoverbeekina spp.

Pl. 21, Figs. 19-20

Material:-Tangential sections, GK.D 13087 from Kpp-37 and GK.D 14197a from Kpp-39.

Descriptive remarks:-Very incomplete two specimens referable to the genus Eoverbeekina have been found in the Khao Phlong Phrab collection. They are not one and the same species, but referable to two different species. They are too insufficient to give a full description.

One specimen (GK.D 13087), which has a width of $1.75 \mathrm{~mm}$ and at least six volutions, is small and subspherical shell with a short axis of coiling. Its radius vectors measure $100,170,270,455,670$, and 990 microns, respectively in probably the first to sixth volutions. Spirotheca is relatively thick, with thickness of 11, $18,38,39$, and 42 microns, probably in the first, third to sixth volutions. Spirotheca is not clear in structure, but very faint alveolar-like structure is seen in parts of outer volutions. Septa unfluted. 
Enough information is not available from the above description, but this specimen is rather closely similar to Eoverbeekina cheni described by THOMPSON and FOSTER (1937) from the uppermost unit of the Yanghsin Limestone (Middle Permian) of the Mt. Omei region, Szechuan. They may be conspecific with each other, but more materials are necessary before the definite specific assignment is done.

The other specimen (GK.D 14197a) is small and subspherical shell with short axis of coiling and broadly rounded periphery. Shell has eight volutions and 1.33 $\mathrm{mm}$ in length and $1.82 \mathrm{~mm}$ in width, with a form ratio of 0.73 . Radius vectors of the first to eighth volutions are $72,120,175,272,375,505,665$, and 855 microns, respectively. Spirotheca thin, having thickness of 12,13,16, 17, 21, 21, and 21 microns, respectively in the second to eighth volutions. Spirothecal structure is not clear. Parachomata are relatively well defined except in inner few volutions. They are about one-fourth to a half as high as chambers.

This specimen is somewhat similar in shell dimension and shape to Eoverbeekina sphaerulinaeformis described by SHENG (1963) from the Upper Permian Hoshan Formation, Kwangsi, South China, but the former is clearly distinguished from the latter, by having less numerous number of volution and well developed parachomata. Further study on enough material is necessary to make final specific determination.

Occurrence:-GK.D 13087 from the uppermost part of the $B_{4}$ zone, and GK.D 14197a from the basal part of the $\mathrm{B}_{5}$ zone.

\section{References}

Chen, S. (1934) : Fusulinidae of South China, Part I. Palaeontologia Sinica, [B], IV, (2), 1-185, pls. I-XVI.

(1956) : Fusulinidae of South China, Part II. Palaeontologia Sinica, N.S. B, 6, 17-71, pls. I-XIV.

Colani, M. (1924): Nouvelle contribution a l'étude des Fusulinidés de l'ExtremeOrient. Mém. Serv. Géol. l'Indochine, XI, (1), 1-191, pls. 1-29.

Coogan, A. H. Stratigraphy and Palaeontology of the Permian Nosoni and Dekkas Formations (Bollibokka Group). Univ. Calif. Publ. Geol. Sci., 36, (5), 243-316, pls. 22-27.

DePrat, J. (1912) : Étude des Fusulinidés de Chine et d'Indochine et classification des calcaires à fusulines. Mém. Serv. Géol. l'Indochine, I, (3), 1-76, pls. 1-9.

(1913): Etude des Fusulinidés de Chine et d'Indochine et classification des calcaires ( $\mathrm{II}{ }^{\mathrm{e}}$ Mémoire). Les Fusulinidés des calcaires carbonifériens et permiens du Tonkin, du Laos et du Nord-Annam. ditto., II, (1), 1-74, pls.1-10.

- (1914) : Etude des Fusulinidés du Japon, de Chine et d'Indochine et classification des calcaires à fusulines (III ${ }^{\bullet}$ Mémoir). Etude comparative des Fusulinidés d'Akasaka (Japon) et des Fusulinidés de Chine et d'Indochine. ditto., III, (1), 1-45, pls. 1-8.

(1915): Etude des Fusulinidés de Chine et d'Indochine et classification des calcaires à fusulines (IV Mémoir). Les Fusulinidés des calcaires carbonifériens et permiens du Tonkin, du Laos, et du Nord-Annam. ditto., IV, (1), 1-30, pls. 1-3.

Doutkevitch, G. A. and Khabakov, A. B. (1934): Permian fauna of Fusulinidae found in Sections of Kara-su and Kuberganda in East Pamir. Acad. Sci. USSR, Tadjik Complex Exped, 1932, Geol. Pamir, 8, 53-104, pls. 1-3.

Douvilué, M. H. (1906) : Les Calcaires à Fusulinidés de l'Indochine. Bull. Soc. Géol. 
France, [4], 6, 576-587, pls. 17, 18.

Dunbar, C. O. in HeIM and HIRSCH (1930): A section of mountain-ranges of Northwestern Siam. Ecol. Geol. Helvetiae, 32, (1), 1-161, pl.1.

(1939) : Permian fusulines from Central America. Jour. Paleont, 13, 344-348, pls. 35-36.

and Henbest, L. G. (1930) : The fusulinid genera Fusulina, Fusulinella, and Wedekindella. Am. Jour. Sci. 5th Ser., 20, 357-365.

Fujimoto, H. and ToriYama, R. (1963) : A survey of the fossils from Japan illustrated in classical monographs, Part III. Revision on "Carbonische Foraminiferen aus China und Japan" von C. Schwager. Palaeont. Soc. Japan, 25th Anniv. vol., 5-7, pls. 13-16.

Geinitz, H. B. (1876) : Zur Geologie von Sumatra. I. Zur Geologie von Sumatra's Westküste. Palaeontographica, 22, 399-404.

Gubler, J. (1935) : Les Fusulinidés du Permien de l'Indochine, Leur structure et leur classification. Soc. Géol. France, Mém., n.s., 11, (4), 26, 1-173, pls. 1-8 (17-24).

GüMBeL, C. W. (1878) : Anleitungen zu wissenschaftlichen Beobachtungen auf Alpenreisen. Beil. Zeit. Deutch. u. Östrr. Alpenvereins, 1878, 1-192, Leipzig.

Hanzawa, S. (1942) : Parafusulina yabei n. sp. from Tomuro, Simotuke Province, Japan. Japan. Jour. Geol. Georg., 19, (1-4), 127-131, pls. 13-14.

(1950): On the occurrence of Foraminiferal Genera, Eoverbeekina, Nankinella, and Sphaerulina from Japan. Short Papers, Inst. Geol. Palaeont. Tohoku Univ., 2, 1-12, pls. 1-2.

Hayden, H. H. (1909): Fusulinidae from Afghanistan. India Geol. Surv. Records, 38, 230-256, pls. 17-22.

HEIM, A. and HIRSCH, H. (1930): A section of the mountain ranges of Northwestern Siam. Ecol. Geol. Helvetiae, 32, (1), 1-161, pl. 1.

Huzrмото, H. (1936): Stratigraphical and Palaeontological Studies of the Titibu System of the Kwanto-Mountainland, Pt. 2, Palaeontology. Sci. Rept. Tokyo Bunrika Daigaku, [C], 1, (2), 29-125, pls. I-XXVI.

Honjo, S. (1959) : Neoschwagerinids from the Akasaka Limestone (A Palaeontological Study of the Akasaka Limestone, 1st Report). Jour. Fac. Sci. Hokkaido Univ., [4], 10, (1), 11-161, pls. 1-12.

Igo, H. (1959) : Some Permian Fusulinid from the Hirayu District, Southeastern part of the Hida massif, Central Japan. Sci. Rept. Tokyo Kyoiku Daigaku, [C], 6, (56), 231-254, pls. 1-4.

(1964): Permian fossils from Northern Pahang, Malaya. Japan. Jour. Geol. Geogr., 35, (1), 55-71, pl. 2. [=Geol. Palaeont. Southeast Asia, 1, 191-208, pl. 2. Univ. Tokyo Press]

(1967) : Some Permian Fusulinids from Pahang, Malaya. Geol. Palaeont. Southeast Asia, 3, 30-38, pls. 4-9. Univ. Tokyo Press.

(1972) : Fusulinacean fossils from North Thailand. (Fusulinacean fossils from Thailand, Pt. VI). Geol. Palaeont. Southeast Asia, 10, 63-116, pls. 9-19. Univ. Tokyo Press.

IsHII, K. (1966a): On some Fusulinids and other Foraminifera from the Permian of Pahang, Malaya. Jour. Geosci., Osaka City Univ., 9, (4-V), 131-136, pls. 5-6. (1966b) : Preliminary notes of the Permian Fusulinids of H. S. LEE Mine No. 8 Limestone near Kampar, Perak, Malaya. ditto., 145.

Ishir, K. and Nogami, Y. (1961): On the new genus Metadoliolina. Trans. Proc. Palaeont. Soc. Japan, N.S., 44, 161-166, pl. 25.

and - (1964): Contributions to the geology and palaeontology of Cambodia, Part 1. Permian Fusulinids. Jour. Geosci., Osaka City Univ., 8, (2), 9-37, pls. 1-8.

IsHIZAKI, K. (1962) : Stratigraphical and palaeontological studies of the Onogahara and its neighbouring area, Kochi and Ehime Prefectures, Southwest Japan. Sci. 
Rept. Tohoku Univ., 2nd Ser., 34, (2), 95-185, pls. 7-12.

(1963): Verbeekininae from the inferred Upper Wolfcampian Limestone in the west of Ryoseki, Kochi Prefecture. Trans. Proc. Palaeont. Soc. Japan, N.S., 50, 51-64, pl. 9 .

KAHLer, F. and Kahler, G. (1966-67) : Fossilium Catalogus, I: Animalia, Fusulinida (Foraminiferida) pars 111-114, 1-974. Uitgeverij Dr. W. Junk's-Gravenhage.

Kanmera, K. (1956): Toriyamaia, a new Permian Fusulinid genus from the Kuma massif, Kyushu, Japan. Trans. Proc. Palaeont. Soc. Japan, N.S., 24, 251-257, pl. 36.

(1957): Revised classification of Cancellina and Neoschwagerina, and evolution of Sumatrininae and Neoschwagerininae. Mem. Fac. Sci., Kyushu Univ., [D], 6, (1) , 47-64, pls. 19-20.

(1958): Fusulinids from the Yayamadake Limestone of the Hikawa Valley, Kumamoto Prefecture, Kyushu, Japan. Part III-Fusulinids of the Lower Permian. ditto., 6, (3), 153-215, pls. 24-35.

(1963) : Fusulines of the Middle Permian Kozaki Formation of Southern Kyushu. ditto., 14, (2), 79-141, pls. 11-19.

and TORIYAMA, R. (1968) : Maklaya, new generic designation for Neoschwagerinids of the group of Cancellina pamirica Leven. (Fusulinacean fossils from Thailand, Part III). Geol. Palaeont. Southeast Asia, 5, 31-46, pls. 4-5. Univ. Tokyo Press.

KANUMA, M. (1960): Stratigraphical and paleontological studies of the southern part of the Hida plateau and north-eastern part of the Mino Mountainland, Central Japan, Pt. 2, Paleontology, No. 4. Bull. Tokyo Gakugei Univ., 11, 55-83, pls. 10-13.

Kawano, M. (1961): Stratigraphical and paleontological studies of the Paleozoic Formations in the western part of the Chugoku massif. Bull. Fac. Educ. Yamaguchi Univ., Mathem. \& Sci., 11, 1-133, pls. 1-15.

KLING, S. A. (1960): Permian Fusulinids from Guatemala. Jour. Paleont., 34, (4), $637-655$, pls. $78-82$.

Kobayashi, M. (1957): Paleontological study of the Ibukiyama Limestone, Shiga Prefecture, Central Japan. Sci. Rept. Tokyo Kyoiku Daigaku, [C], 48, 247-311, pls. 1-10.

Kobayashi, T. (1964): Geology of Thailand. Geol. Palaeont. Southeast Asia, 1, 1-15. Univ. Tokyo Press.

(1964b) : Paleontology of Thailand (1916-62). ditto., 17-29. Univ. Tokyo Press.

Kochamsky-Devidé, V. (1955) : Karbonske i Permske Fusulinidne Foraminifere Velebita i Like. 1. Opci dio i karbon. R.A.D. Jugoslav. Akad. Znanosti $i$ Umjet, 305, 5-62, pls. 1-6.

(1958): Die Neoschwagerinenfaunen der südlichen Crna Gora (Montenegro). Geol. Vjesnik, 11, 1957, 45-76, pls. 1-6.

(1959): Karbonske i Permske Fusulinidne Foraminifere Velebita i Like. Donji Perm. Palaeont. Jugoslavica, Jugosl. Akad. Znanosti i Umjet. 1-61, pls. 1-8. in RAmovs, A. (1955): Neoschwagerinski Slkadi in njih fuzulinidna Fauna pri Bohinjski Beli in Bledu. Slovenska Akad. Znanosti in Umetn., Akad. Sci. et Art. Slovenica, Cl.4, Razprave Dissertations, 359-424, pls. 1-8.

Konishi, K. (1953): New Boultonia and other microfossils from North Thailand. Trans. Proc. Palaeont. Soc. Japan, N.S., 12, 103-110.

LEE, J. S. (1923) : A graphic method to aid specific determination of Fusulinoids, and some results of its application to the Fusulinidae from North China. Bull. Geol. Soc. China, 2, (3-4), 51-86, pls. 1-2.

(197) : Fusulinidae of North China. Palaeont. Sinica, [B], 4, (1), 1-172, pls. 1-24.

(1931): Distribution of the dominant types of Fusulinoid Foraminifera in the Chinese Seas. Bull. Geol. Soc. China, 10, 273-290, pl.1. 
(1933): Taxonomic criteria of Fusulinidae with notes on seven new Permian genera. Mem. Nat. Res. Inst. Geol., 14, 1-32, pls. 1-5.

LÊ-Thi-Vièn (1959): Étude de Fusulinidés du Haut Laos, du Cambodge et du Sud Viet-Nam. Ann. Fac. Sci. Saigon, 1959, 99-120, pls. 1-2.

Leven, E. Ya (1964): On the systematics of Family Verbeekinidae. Paleont. Jour. 4, Acad. Nauk. USSR, 23-31.

(1967): Stratigraphy and Fusulinides of the Pamirs Permian deposits. Acad. Sci. USSR, Geol. Inst. Transact., 167, 1-224, pls. 1-39.

LI, C. and $\mathrm{CHU}, \mathrm{S}$. (1934): Note on the stratigraphy of the environs of the Maping city, Central Kwangsi. Bull. Geol. Soc. China, 13, 215-232.

Lys, M. and LApParent, A. F. de (1971) : Foraminifères et microfaciè du Permien de l'Afghanistan central. Notes et Mém. sur le Moyen-Orient. Mus. Nat. d'Hist. Natur., 49-133, pls. 7-22.

Miklukho-Makalay, A. D. (1948): Upper Paleonoic Fusulinids of Central Asia (Fergana, Darwas and Pamir). Monograph. Izd. Lgu, 1949, 3-111, 14 pls.

(1955): New evidence upon the Permian fusulinids of southern part of USSR. Dokl. Acad. Nauk., T., 105, 573-576.

(1957) : Some Fusulinids from the Permian of Crimea. Uchenye Zapiski Lgu, Ser. Geol. Nauk, 9, 1957, 225, 93-159, pls. 1-4.

MORIKAWA, R. (1955) : Schwagerininae in the vicinity of the Shomaru pass, eastern part of Kanto Mountainland, Central Japan. Sci. Rept. Saitama Univ., [B], II, (1) , 45-114, pls. 5-15.

(1958) : Fusulinids from the Akasaka Limestone (Part 1) : ditto., III, (1), 93130 , pls. 12-26.

and Isomi, H. (1961): Studies of Permian Fusulinids in the east of Lake Biwa, Central Japan. Geol. Surv. Japan, Rept., 191, 1-30, pls. 1-21.

Nogami, Y. (1961a): Permische Fusuliniden aus dem Atetsu-Plateau Sudwestjapans, Teil 1. Fusulininae und Schwagerininae. Mem. Coll. Sci., Kyoto Univ., [B], XXVII, (3), 159-225, pls. 1-11.

(1961b): Permische Fusuliniden aus dem Atetsu-Plateau Sudwestjapans, Teil 2. Verbeekininae, Neoschwagerininae u.a., ditto., XXVIII, (2), 159-228, pls. 1-7.

OzAWA, T. (1970a) : Notes on the phylogeny and classification of the Superfamily Verbeekinoidea (Studies of the Permian Verbeekinoidean Foraminifera-1). Mem. Fac. Sci., Kyushu Univ., [D], XX, (1), 17-58, pls.1-9.

(1970b): Variation and relative growth of Colania douvillei (OzAwa) from the Rat Buri Limestone. Geol. Palaeont. Southeast Asia, 8, 19-42, pls. 3-6. Univ. Tokyo Press.

OzawA, Y. (1922) : Preliminary note on the classification of the Family Fusulinidae. Jour. Geol. Soc. Japan, 29, 352-365 (in Japanese).

(1925a): On the classification of Fusulinidae. Jour. Coll. Sci. Imp. Univ. Tokyo, $45,(4), 1-26$, pls. $1-4$.

(1925b) : Palaeontological and stratigraphical studies on the Permo-Carboniferous limestone of Nagato, pt. 2, Palaeontology. ditto., 45, (6), 1-90, pls.1-14.

(1927) : Stratigraphical studies of the Fusulina limestone of Akasaka, Province of Mino. Jour. Fac. Sci. Imp. Univ. Tokyo, [2], 2, (3), 121-164, pls. 34-46.

and Tobler, A. (1929): Permian Fusulinidae found in Greece. Ecol. Geol. Helvetiae, 22, (1), 45-49, pl. 5.

Pitakpaivan, K. (1965): Fusulines of the Rat Buri Limestone of Thailand (The Fusulinacean fossils of Thailand, Pt. 1): Mem. Fac. Sci., Kyushu Univ., [D], XVII, (1), 3-69, pls. 1-6. [=Geol. Palaeont. Southeast Asia, 2, 63-129, pls. 1-6, 1966. Univ. Tokyo Press]

Pitcher, M. G. (1960) : Fusulinids of Cache Creek Group, Stikine River area, Cassiar district, British Columbia, Canada. Brigham Young Univ., Res. Stud., Geol. Ser., 7, (7). 
RAuser-Chernoussova, D. M. and Fursenko, A. V. (1959): Osnovi Paleontologii. Akad. Nauk. SSSR.

RoBinson, G. B. Jr. (1961) : Stratigraphy and Leonardian fusulinid paleontology in central Pequop Mountains, Elko County, Nevada. Brigham Young Univ., Geol. Stud., 8, 93-145, pls. 17-20.

RoEmer, F. (1880) : Über eine Kohlenkalk-Fauna der Westküste von Sumatra. Palaeontographica, 27, 1-11, pls. 1-3.

(1881): Jaarboek van het Mijnwezenm, 1881.

Ross, C. (1962) : Permian Foraminifera from British Honduras. Palaeont., 5, (2), 277-306, pl. 46.

SADA, K. (1963): Neoschwagerina from Joé limestone, Hiroshima Prefecture, West Japan, with a note on Neoschwagerina margaritae DePrat. Geol. Rept. Hiroshima Univ., (12), 541-552, pl. 58.

(1964): Carboniferous and Permian Fusulines of the Atetsu Limestone in West Japan. Jour. Sci. Hiroshima Univ., [C], 4, (3), 125-269, pls. 21-28.

(1965): Carboniferous and Permian stratigraphy of the Atetsu Limestone in West Japan. ditto., 5, (1), 21-80, pl. 1.

SaKaGami, S. (1958): Fusulinids from the Upper Permian conglomerates of the northern part of Itsukaichi, Tokyo-To, Japan. Jour. Hokkaido Gakugei Univ., 9 (2), 72-97, pls. 1-4.

(1968): Permian Bryozoa from Khao Chong Krachok, Peninsular Thailand. Geol. Palaeont. Southeast Asia, 4, 67-81, pl. 13. Univ. Tokyo Press.

(1969) : On some Permian Fusulinaceans from Peninsular Thailand (Fusulinacean fossils from Thailand, Pt. 4). ditto., 6, 265-275, pls. 27-28. Univ. Tokyo Press.

- and IwaI, J. (1974): Permian Fusulinaceans from the Pha Duk Chik Limestone and in the limestone conglomerate in its environs, North Thailand (Fusulinacean fossils from Thailand, Pt. 8). ditto., 14, 49-81, pls. 4-9.

Sakaguchi, S. and Sugano, K. (1966) : Mem. Osaka Univ. Liberal Arts \& Educ., [B], $15,143-148,1 \mathrm{pl}$.

SAURIN, E. and LE-THI-VIEN (1960): Le Sakmarien de Nhommarath (Laos) et ses Fusulinidae. Ann. Fac. Sci. Saigon, 191, 377-402, pls.1-3.

Schellwien, E. (1898): Die Fauna des Karnischen Fusulinenkalkes. Teil 2. Foraminifera. Palaeontographica, 44, 237-282, pls. 17-24.

SCHWAGER, C. (1883) : Carbonische Foraminiferen aus China und Japan, in von RICHTHOFEN, China, 4, 105-159, pls. 15-18.

Sheng, J. S. (1956) : Permian Fusulinids from Lianghan, Hanchung, Southern Shansi. Acta Palaeont. Sinica, 4, (2), 175-228, pls. 1-8.

(1958): Some Fusulinids from the Maokou Limestone of Chinghai Province, Northwestern China. ditto., 6, (3), 268-291, pls. 1-4.

(1962): Some Fusulinids of the Chihsia Stage, Northern Hopei. ditto., 10, (4), 426-432, pl. 1 .

(1963) : Permian Fusulinids of Kwangsi, Kueichow and Szechuan. Palaeont. Sinica, N.S., B, 10, 1-247, pls. 1-36.

(1965) : Fusulinids from the western part of Hainan Island, Kwangtung Province. Acta Palaeont. Sinica, 13, (4), 563-583, pls. 1-7.

Silvestri, A. (1933): Fusulinidi dell'Antracolitico della Valle del Sosio (Palermo). Mem. Inst. Geol. R. Univ. Padova, 10, 1-45, pls. 1-3.

Skinner, J. W. and Wilde, G. L. (1966a) : Permian Fusulinids from Pacific Northwest and Alaska. Univ. Kansas Paleont. Contrib., Paper 4, 1-64, pls. 1-49. and $-(1966 \mathrm{~b}):$ Permian Fusulinids from Sicily. ditto., Paper 8, 1-16, pls. 1-20.

Staff, H. von (1909): Beiträge zur Kenntnis der Fusuliniden. Neues Jahrb. Min. Geol. Palaeont., Beil. Bd., 27, 461-508, pls. 7-8. 
(1912): Monographie der Fusulinen. Teil III. Die Fusulinen Nordamerikas. Palaeontographica, 59, 157-192, pls. 15-20.

StEwart, W. J. (1963) : The Fusulinid genus Chusenella and several new species. Jour. Paleont., 37, (6), 1150-1163, pls. 155-158.

SugI, T. (1960) : Restudy of Verbeekina sphaera Ozawa. Trans. Proc. Palaeont. Soc. Japan, N.S., 39, 311-320, pl. 36.

SUYARI, K. (1962): Geological and paleontological studies in central and eastern Shikoku, Japan, Pt. 2, Paleontology. Jour. Gakugei, Tokushima Univ., Nat. Sci., 12, 1-64, pls. 1-12.

Thompson, M. L. (1935): The fusulinid genus Yangchienia LeE. Ecol. Geol. Helvetiae, 28, (2), 511-517, pl. 17.

(1936a): The Fusulinid genus Verbeekina. Jour. Paleont., 10, (3), 193-202, pl. 24.

(1936b) : Lower Permian Fusulinids from Sumatra. ditto., 587-592.

(1946) : Permian Fusulinids from Afghanistan. ditto., 20, (2), 140-157, pls. 23-26.

(1948): Studies of American Fusulinids. Univ. Kansas, Paleont. Contrib., Protozoa, art. 1, 1-184, pls. 1-38.

and Foster, C. L. (1937): Middle Permian Fusulinids from Szechuan, China. Jour. Paleont., 11, (2), 126-144, pls. 23-25.

and Miller, A. K. (1944) : The Permian of Southernmost Mexico and its Fusulinid Faunas. ditto., 18, (6), 481-504, pls. 79-84.

- Wheeler, H. E. and Hazzard, J. C. (1946) : Permian Fusulinids of California. Geol. Soc. Amer. Mem., 17, 77p. 18 pls.

Ting, C. S. (1962) : On some Fusulinids from Chinghai Province. Acta Paleont. Sinica, $10,(4), 444-450$.

TORIYAMA, R. (1944): On some Fusulinids from Northern Tai. Japan. Jour. Geol. Geogr., 19, (1-4), 67-82, pl. 6.

(1958): Geology of Akiyoshi, Pt.3. Fusulinids of Akiyoshi. Mem. Fac, Sci., Kyushu Univ., [D], 7, 1-264, pls. 1-48.

and Kanmera, K. (1968): Two new Permian genera from Thailand (Fusulinacean fossils from Thailand, Pt.2). Geol. Palaeont. Southeast Asia, 4, 29-44, pls. 6-8. Univ. Tokyo Press.

, KaNMERA, K. and Ingavat, R. (1966) : Neofusulinella from Thailand. (Fusulinacean fossils from Thailand, Pt. 5). ditto., 7, 15-32, pls. 3-4.

- - - KaEwBaidhoon, S., and Hongnusonthi, A. (1974): Biostratigraphic zonation of the Rat Buri Limestone in the Khao Phlong Phrab area, Sara Buri, Central Thailand. ditto., 14, 25-48.

and PitakPaivan, K. (1973) : Middle Permian Fusulines from Wat Kirinakratanaram, Central Thailand. (Fusulinacean fossils from Thailand, Pt. 7). ditto., $12,43-61$, pls. 5-6.

Verbeek, R. D. M. and Fennema, R. (1896): Description géologique de Java et Madoura, Amsterdam, 2, 1134.

YABE, H. (1899): On Fusulina japonica Schwager from Tomuro, Province of Shimotsuke. Jour. Geol. Soc. Tokyo, 6, (68), 189-194 (in Japanese). (1903): Fusulina japonica limestone. ditto., 10, (123), 585-586 (in Japanese). (1906): A contribution to the genus Fusulina, with notes on a Fusulina-limestone from Korea. Jour. Coll. Sci., Imp. Univ. Tokyo, 21, (5), 1-36, pls. 1-3. and Hanzawa, S. (1932): Tentative classification of the Foraminifera of the Fusulinidae. Proc. Imp. Acad. Japan, 8, (2), 40-43. 


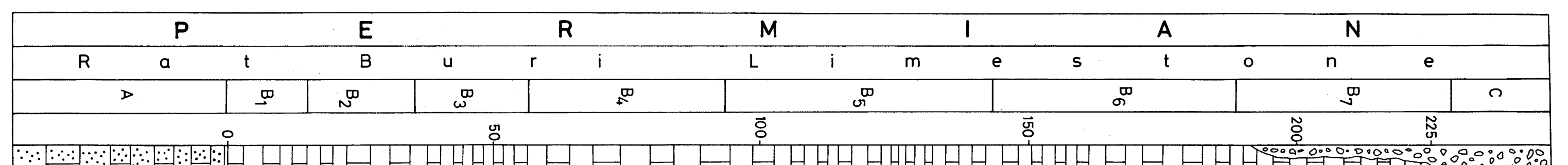

$\because 0,0$ :

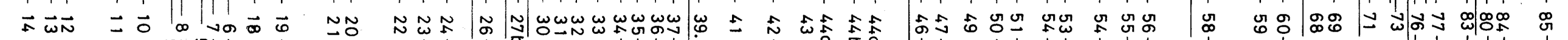

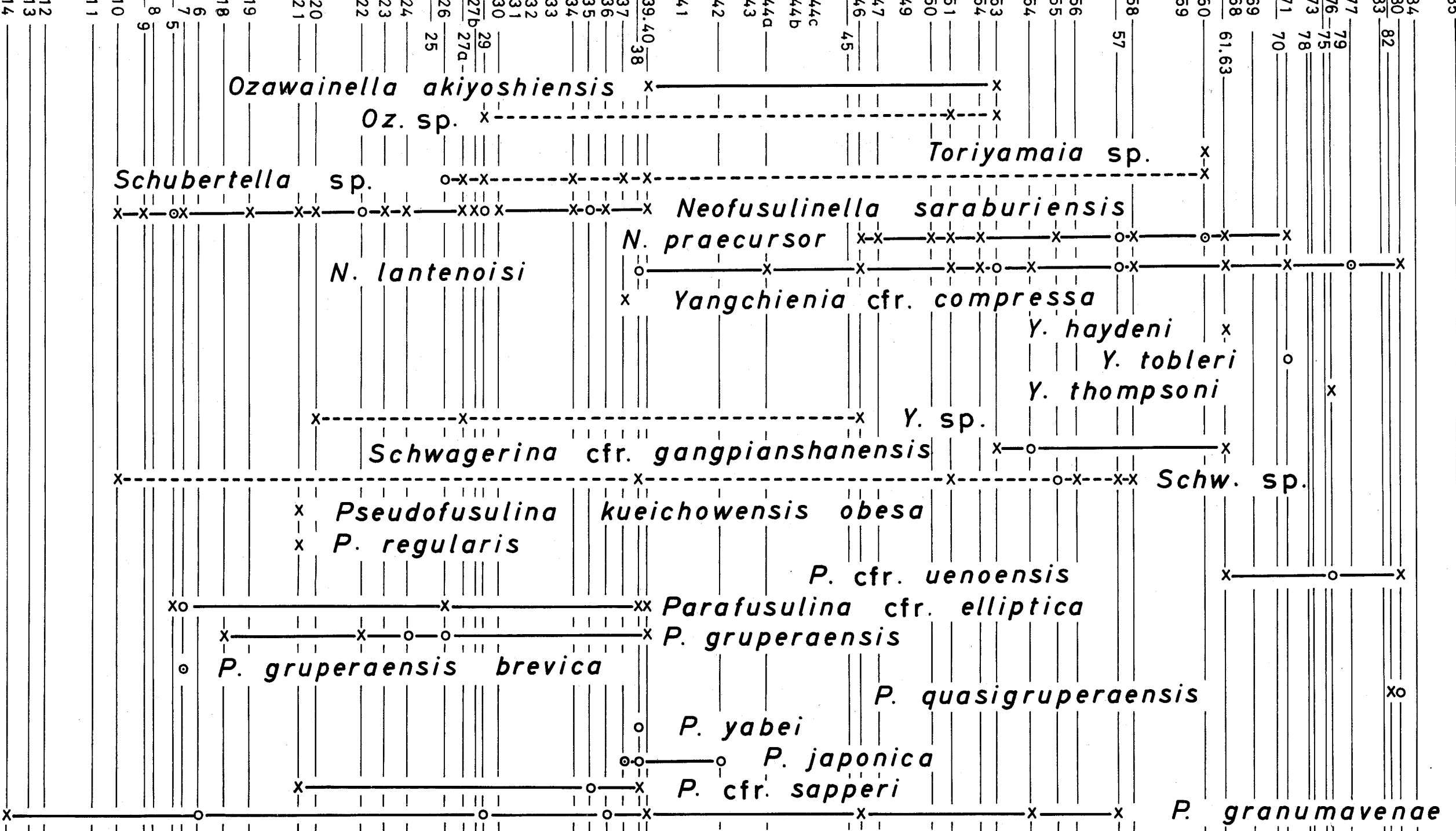

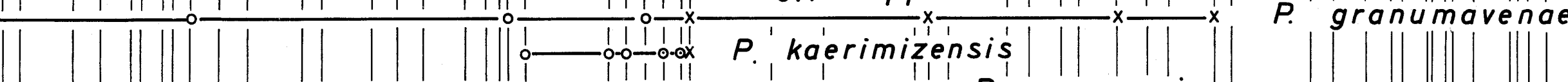

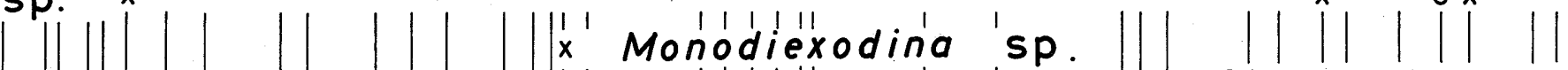

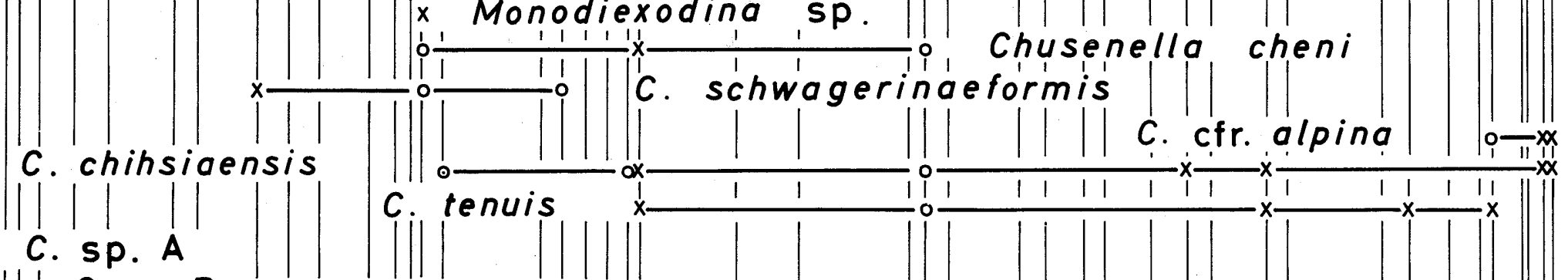

C. Sp. A

C.sp. || $\mid$ C. Sp. B

S. Misellina otai

o-o-oo M. cfr. termieri

c. sp
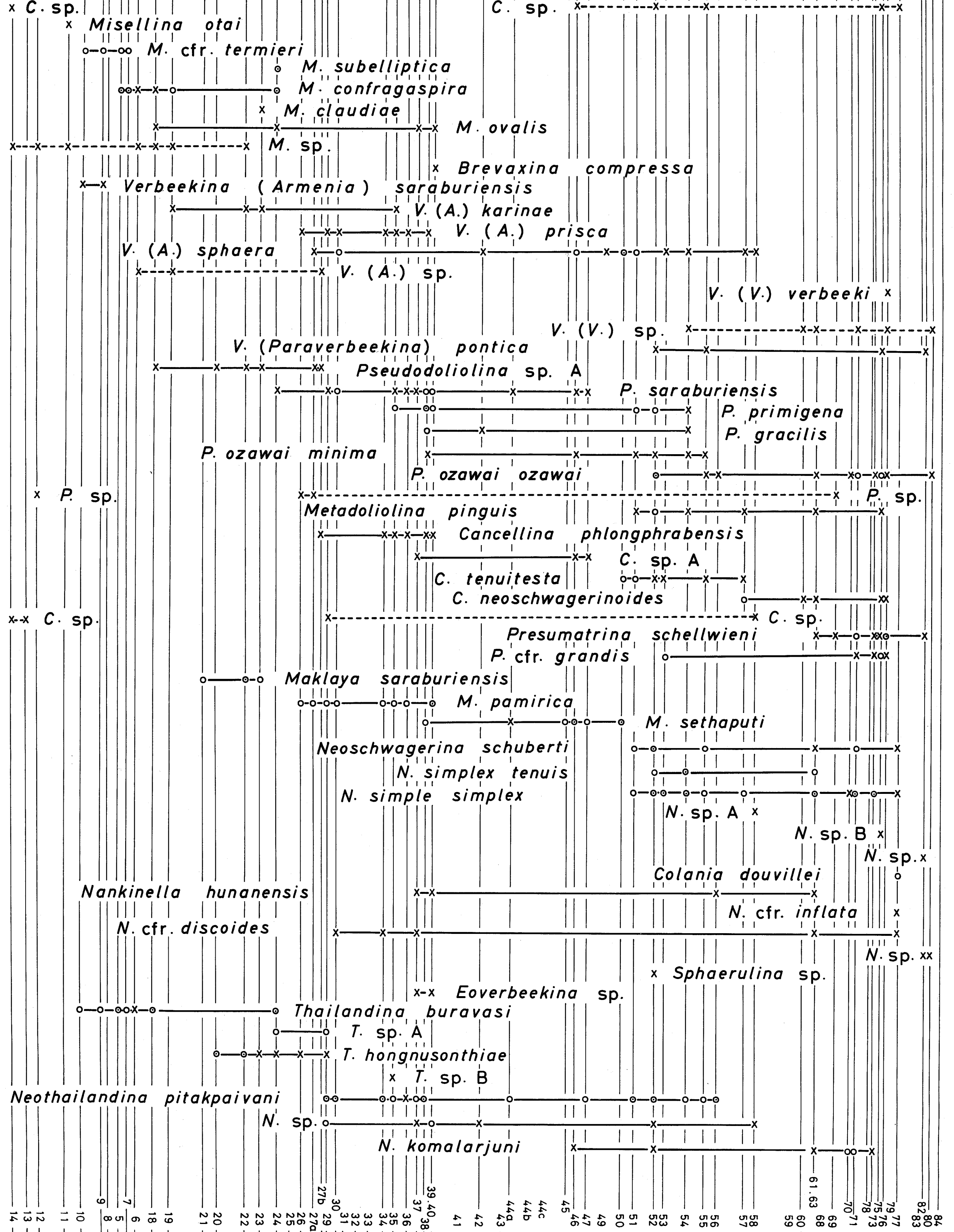

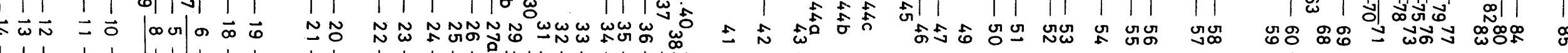

